UNIVERSIDADE DE SÃO PAULO

FACULDADE DE ECONOMIA, ADMINISTRAÇÃO E CONTABILIDADE DEPARTAMENTO DE CONTABILIDADE E ATUÁRIA PROGRAMA DE PÓS-GRADUAÇ̃̃̃o EM CIÊNCIAS CONTÁBEIS

ADOÇÃO DO PADRÃO CONTÁBIL INTERNACIONAL NAS PEQUENAS E MÉDIAS EMPRESAS E SEUS EFEITOS NA CONCESSÃO DE CRÉDITO

Enrico Dalla Riva

Orientador:

Prof. Dr. Bruno Meirelles Salotti

SÃO PAULO 
Prof. Dr. João Grandino Rodas

Reitor da Universidade de São Paulo

Prof. Dr. Reinaldo Guerreiro

Diretor da Faculdade de Economia, Administração e Contabilidade

Prof. Dr. Edgar Bruno Cornachione Junior

Chefe do Departamento de Contabilidade e Atuária

Profa. Dra. Silvia Pereira de Castro Casa Nova

Coordenadora do Programa de Pós-Graduação em Ciências Contábeis 
ENRICO DALLA RIVA

\section{ADOÇÃO DO PADRÃO CONTÁBIL INTERNACIONAL NAS PEQUENAS E MÉDIAS EMPRESAS E SEUS EFEITOS NA CONCESSÃO DE CRÉDITO}

Dissertação apresentada ao Departamento de Contabilidade e Atuária da Faculdade de Economia, Administração e Contabilidade da Universidade de São Paulo como requisito para obtenção do título de Mestre em Ciências.

Área de Conhecimento: Ciências Contábeis

Orientador: Prof. Dr. Bruno Meirelles Salotti

\section{Versão Corrigida}

(Versão original disponível na Faculdade de Economia, Administração e Contabilidade)

\section{SÃO PAULO}


Autorizo a reprodução e divulgação total ou parcial deste trabalho, por qualquer meio convencional ou eletrônico, para fins de estudo e pesquisa, desde que citada a fonte.

\section{FICHA CATALOGRÁFICA}

Elaborada pela Seção de Processamento Técnico do SBD/FEA/USP

Riva, Enrico Dalla

Adoção do padrão contábil internacional nas pequenas e médias empresas e seus efeitos na concessão de crédito / Enrico Dalla Riva. - São Paulo, 2013.

$178 \mathrm{p}$.

Dissertação (Mestrado) - Universidade de São Paulo, 2013.

Orientador: Bruno Meirelles Salotti.

1. Padrões e normas contábeis 2. Pequenas e médias empresas 3. Divulgação de informações financeiras 4. Crédito bancário I. Universidade de São Paulo. Faculdade de Economia, Administração e Contabilidade. II. Título.

CDD - 657.0218 
Às minhas famílias Dalla Riva e Braga Viera. 


\section{Agradecimentos}

Estes anos no curso de mestrado em Contabilidade na FEA-USP fizeram parte de mais uma importante fase de minha vida, cujos louros não posso e nem quero usufruir sozinho, assim gostaria de dividir com todos aqueles que me ajudaram. Logo, deixo registrado alguns agradecimentos a pessoas especiais que de certa forma colaboram com este trabalho.

Primeiramente, me dirijo aos meus colegas de mestrado e doutorado da turma de 2011, quanta gente inteligente! Num primeiro momento, confesso que me senti um estranho ninho, mas na medida em que conhecia cada um de vocês percebia que havia uma grande identificação, que privilégio ter tido a oportunidade de conhecê-los. Obrigado pelo apoio nos momentos difíceis, e por compartilhar alegrias com apresentações, exercícios, provas e artigos, sempre. Admiro todos vocês, sem exceção. Especial agradecimento a Cassio, Janílson e Robson, pelas fundamentais colaborações ao trabalho.

Ao corpo docente do PPGCC da FEA-USP, meu profundo reconhecimento. Como é bom aprender com o auxílio de pessoas tão capacitadas e com vontade de transmitir o conhecimento como vocês. Em especial, ao Prof. Dr. Bruno Meirelles Salotti, meu orientador acadêmico, pelo acompanhamento e sugestões sempre pertinentes e valiosas no desenvolvimento do trabalho.

Valiosas também foram as considerações realizadas durante o exame de qualificação pelos professores Giovani Antonio Silva Brito e Fernando Dal-Ri Murcia, vocês acrescentaram muito ao trabalho, obrigado!

Sou grato também à FIPECAFI, Fundação Instituto de Pesquisas Contábeis, Atuariais e Financeiras, detentora da base de demonstrações contábeis analisadas, em especial à Sra. Eliene Silva, sempre disposta a esclarecer dúvidas e me ajudar a encontrar as informações necessárias à elaboração deste trabalho.

Agradeço também ao Banco Central do Brasil, instituição patrocinadora deste mestrado, em especial ao servidor Claudio Filgueiras Pacheco Moreira, meu orientador técnico, que sempre incentivou minhas ideias, desde a decisão pela realização do curso, até o seu desenvolvimento. 
Devo mencionar também meu obrigado ao servidor do Banco Central, Marco Antonio Guimarães Verrone, que facilitou meu acesso aos contatos com as instituições financeiras, as quais também agradeço, por meio de seus executivos, sem poder mencioná-los nominalmente, que reservaram seu precioso tempo para realização das entrevistas, extremamente ricas e proveitosas.

Aos meus amigos e amigas, é sempre bom saber que não preciso nem me desculpar pela minha ausência, quero um abraço de cada um de vocês, irmãos e irmãs escolhidos para o resto da minha vida, sem vocês não sou nada.

À minha família eterna, pai, mãe, Endrigo, Janina e demais agregados, obrigado pelo suporte de todos os dias e carinho de sempre, amo vocês. Manuela, titio vai te ensinar como é bom estudar!

À minha mais nova família, Luiz, Cris, Clau e Ciro, obrigado por ter sido recebido de maneira tão afetuosa por vocês. Nesse trabalho também tem bastante de vocês.

E a você Carol, minha noiva, minha força, meu amor. Obrigado pela compreensão, você não existe! Você entendeu minhas horas de estudos, me ajudou a não desistir nos momentos difíceis e a respirar várias vezes para não explodir. Esse sacrifício foi um investimento para o nosso futuro. Prometo retribuir na construção da nossa família. Amo você! 
"Corro porque isso sempre me leva para onde quero ir"

Dean Karnazes 


\section{RESUMO}

Riva, E. D. (2013). Adoção do padrão contábil internacional nas pequenas e médias empresas e seus efeitos na concessão de crédito. Dissertação de Mestrado, Faculdade de Economia, Administração e Contabilidade (FEA-USP), Universidade de São Paulo, São Paulo.

Esta pesquisa examina a relação entre a adoção do padrão contábil internacional pelas pequenas e médias empresas no Brasil com o custo de crédito concedido pelas instituições financeiras. A literatura teórica discute a regulação contábil como resposta à existência de ambientes com assimetria informacional, e a Teoria da Divulgação estuda o fenômeno da evidenciação contábil, sob o ponto de vista de suas causas e efeitos. O IASB, entre outras razões, propõe um padrão contábil com maior qualidade de informações em razão de ele reduzir o custo de captação de empresas de menor porte. Desse modo, o presente trabalho teve como objetivo principal investigar se adoção do padrão contábil internacional provocou efeito no custo de crédito bancário. A investigação foi conduzida por uma abordagem teórico-empírica, suportada por avaliações qualitativas, associadas a técnicas quantitativas. As análises estatísticas envolveram uma amostra de 179 empresas, em que foram realizadas análises descritivas, testes de médias amostrais e análise de dados em painel, com dados de demonstrações contábeis referentes a três anos (2009 a 2011). Para mensurar o nível de qualidade das informações contábeis, utilizou-se de índice de disclosure formado com base nas demonstrações contábeis das empresas da amostra e verificação de evidenciação do padrão contábil com base no CPC. Foram obtidas evidências de relações estatisticamente significativas entre as medidas de qualidade da informação contábil (disclosure e evidenciação da adoção do padrão contábil baseado no CPC) e o custo de crédito bancário dessas empresas. No entanto, quando observadas as análises regionais e setoriais, essas evidências não se demonstraram significativas e consistentes no tempo. Também foram realizadas nove entrevistas com instituições financeiras. Identificou-se um ambiente de concessão de crédito com alto risco de perdas, em que informações contábeis fazem parte das análises, mas a necessidade de outros instrumentos de mitigação de risco é bastante comum. O mercado de crédito, em geral, vê com bons olhos a adoção do padrão contábil, mas não é evidente que os benefícios irão superar seus custos de implantação.

Palavras-chave: Pequenas e médias empresas. Padrões e normas contábeis. Divulgação de informações financeiras. Crédito bancário. 


\begin{abstract}
Riva, E. D. (2013). Adoption of international accounting standards for small and medium companies and their effects on banking credit. Dissertação de Mestrado, Faculdade de Economia, Administração e Contabilidade (FEA-USP), Universidade de São Paulo, São Paulo.
\end{abstract}

This research examines the relationship between the adoption of the international accounting standard for small and medium-sized entities in Brazil, with the cost of banking funds granted by financial institutions. The theoretical literature discusses the accounting regulation in response to the existence of information asymmetry environments, and the Disclosure Theory studies the phenomenon of accounting disclosure, from the point of view of its causes and effects. The IASB, among other reasons, proposes a pattern with higher quality accounting information due to a supposed reduction in the cost of lending for smaller companies. Thus, the present work has as its main objective to investigate whether the adoption of international accounting standards caused effect on the cost of banking credit. The investigation was conducted by a theoretical and empirical approach, supported by qualitative assessments, combined with quantitative techniques. Statistical analyzes involved a sample of 179 companies, from which were maiden descriptive analysis, tests of means and panel data analysis, with the data of financial statements from three years (2009 to 2011). To measure the level of quality of accounting information, it was used an index of disclosure formed on the basis of the companies' financial statements of the sample and checking of disclosure of accounting standards based on IFRS. There were some evidences of statistically significant associations between measures of quality of accounting information (disclosure and adoption of IFRS accounting standard-based) and the cost of bank loans of these companies, when observed regional and sectorial analyzes, however this evidence did not prove to be significant and consistent in time. Nine interviews were also held with the financial institutions. It was identified an environment of credit at high risk of loss, in which accounting information is part of the analysis, but the need for other instruments of risk mitigation is quite common. The credit market in general welcomes the adoption of the accounting standard, but it is not clear that the benefits will exceed its costs of deployment.

Keywords: Small and medium entities. Accounting standards. Financial reporting. Banking credit. 


\section{SUMÁRIO}

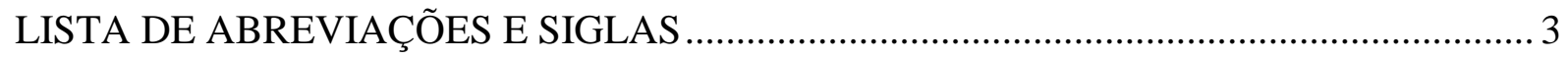

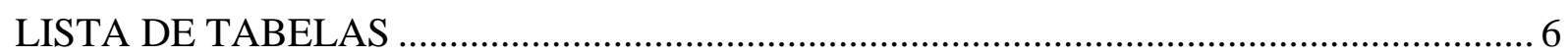

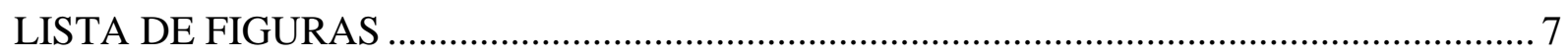

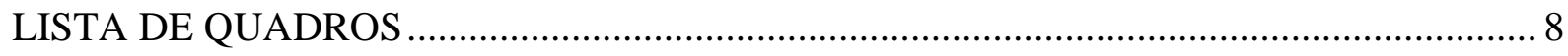

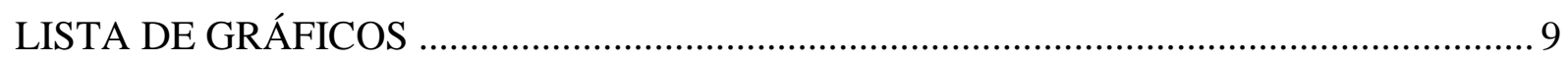

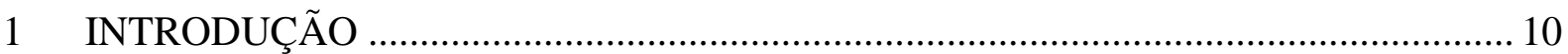

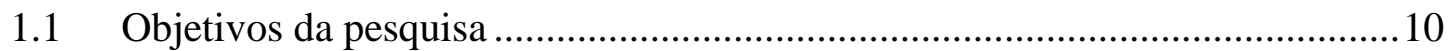

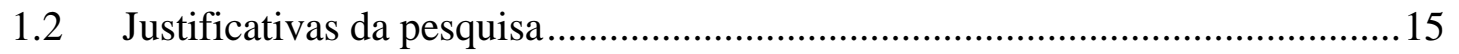

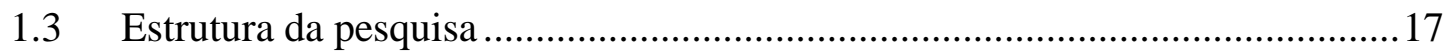

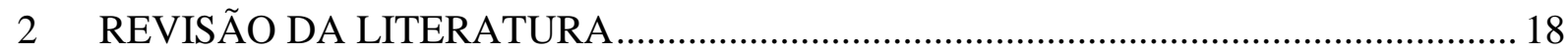

2.1 Aspectos teóricos sobre regulação e divulgação contábil .................................18

2.1.1 Origens da regulação contábil ...................................................................... 18

2.1.2 A regulação contábil sob o olhar da Teoria da Contabilidade ........................... 18

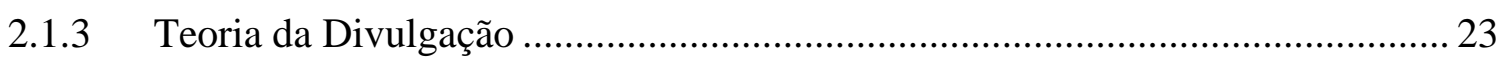

2.1.4 Relação de Custos versus Benefícios ............................................................. 26

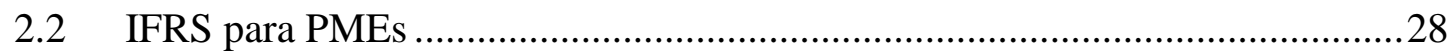

2.2.1 De acordo com o órgão emissor de padrões contábeis internacionais ................ 28

2.2.2 Recepção da norma internacional 'IFRS for SMEs' pelo CFC …...................... 34

2.2.3 Aspectos técnicos da norma CPC para PMEs .................................................. 36

2.2.4 Evidências e críticas sobre aspectos das IFRS para PMEs no mundo ................ 42

2.2.5 Evidências e críticas sobre aspectos das IFRS para PMEs no Brasil .................. 50

2.3 Considerações sobre pequenas e médias empresas brasileiras ..........................53

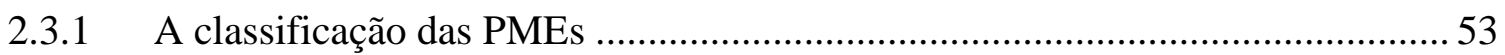

2.3.2 A contextualização das PMEs no cenário brasileiro ........................................... 55

2.3.3 Relação entre as PMEs e a contabilidade ........................................................ 56

2.4 Considerações sobre concessão de crédito pelas IFs a PMEs ...........................57

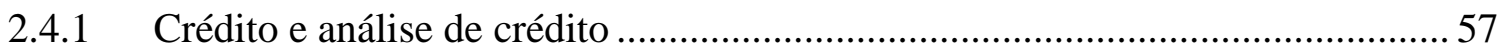

2.4.2 Análise de crédito à PME nas instituições financeiras .......................................5 58

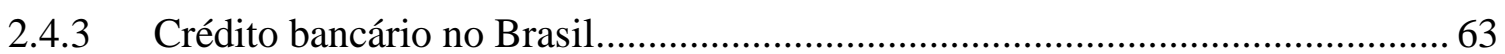

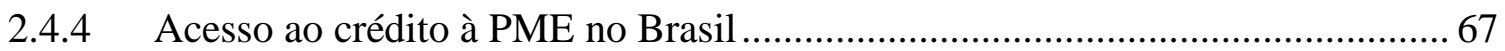

2.4.5 Informações contábeis e análise de crédito em instituições financeiras ............ 71

2.4.6 Informações contábeis e acesso ao crédito às PMEs........................................... 72

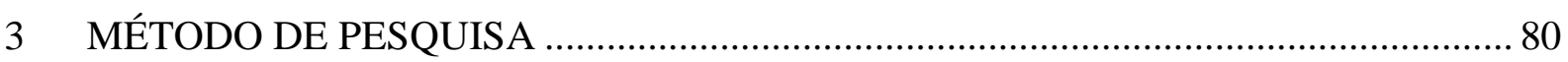




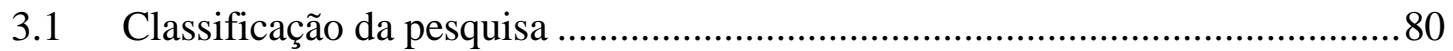

3.2 Coleta de demonstrações financeiras de PMEs ..............................................81

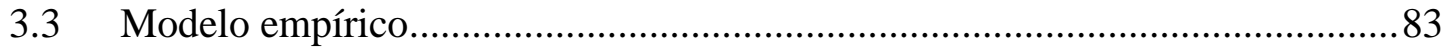

3.3.1 Variáveis exploradas por métodos quantitativos........................................... 83

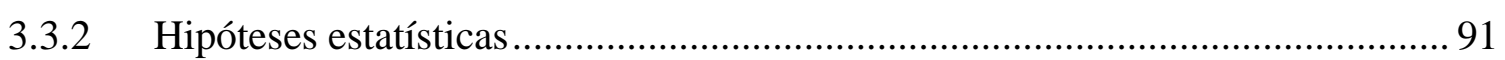

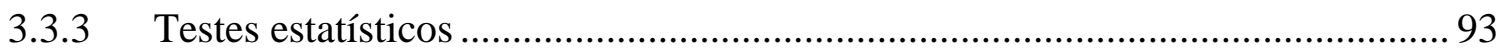

3.4 Entrevistas às instituições financeiras ................................................................98

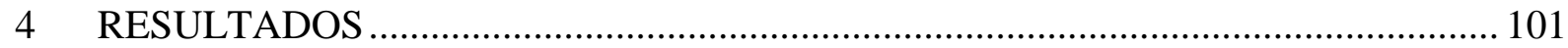

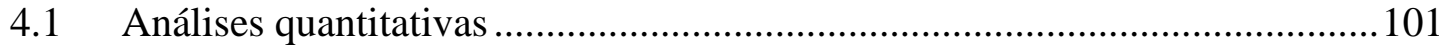

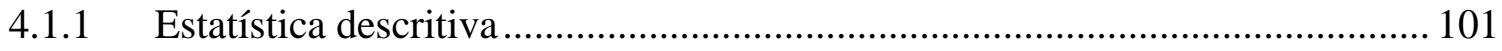

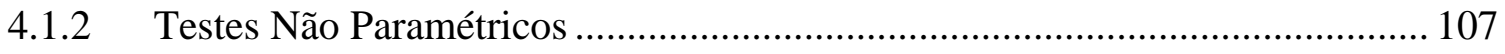

4.1.3 Análise de Dados em Painel .......................................................................... 120

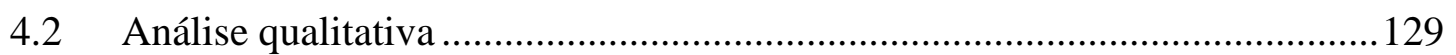

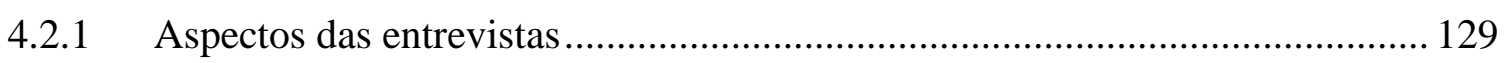

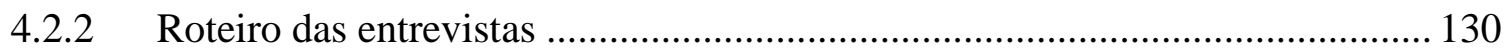

4.2.3 O processo de concessão de crédito ............................................................ 131

4.2.4 As informações contábeis e as complementares nas análises de risco.............. 133

4.2.5 A visão sobre a qualidade da informação contábil ........................................... 135

4.2.6 A visão sobre a relação custo-benefício do padrão contábil ............................. 137

4.2.7 Aspectos sobre educação contábil nas instituições financeiras......................... 138

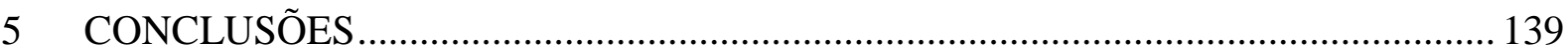

5.1 Resumo das evidências encontradas ............................................................ 139

5.2 Implicações para os usuários da informação ............................................... 142

5.3 Limitações da pesquisa ........................................................................... 144

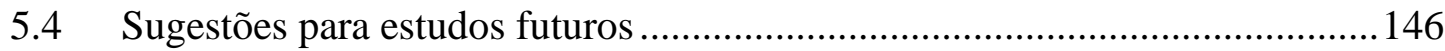

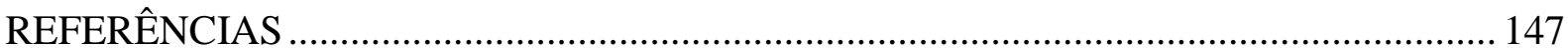

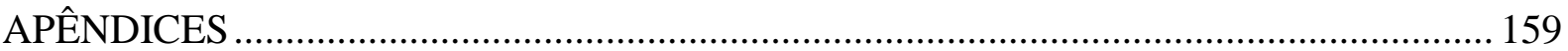

Apêndice A - Exemplo de Cálculo do Índice de Disclosure .................................... 159

Apêndice B - Pauta de entrevista........................................................................... 160

Apêndice C - Cálculo das estatísticas descritivas por Região em 2009 .................... 162

Apêndice D - Cálculo das estatísticas descritivas por Região em 2010 .................... 163

Apêndice E - Cálculo das estatísticas descritivas por Região em 2011 .................... 164

Apêndice F - Cálculo das estatísticas descritivas por Setor em 2009 ....................... 165

Apêndice G - Cálculo das estatísticas descritivas por Setor em 2010 ........................ 166

Apêndice H - Cálculo das estatísticas descritivas por Setor em 2011 ....................... 167

Apêndice I - Matriz de correlação das variáveis (dados em painel) ..........................168 


\section{LISTA DE ABREVIAÇÕES E SIGLAS}

APA

BACEN

$\mathrm{BCB}$

BID

BNB

BNDES

BRI

BRICS

COFINS

CEPAL

CFC

CPA

$\mathrm{CPC}$

CRC

CVM

DFC

DIEESE

DMPL

DRE

EUA

FASB

FDIC

FEA

FEBRABAN

FGV

FINEP

FIPECAFI
American Psychological Association

Banco Central do Brasil

Banco Central do Brasil

Banco Interamericano de Desenvolvimento

Banco do Nordeste

Banco Nacional de Desenvolvimento e Social

Bank Rayat Indonesia

Brazil, Russia, India and China

Contribuição para Financiamento da Seguridade Social

Comissão Econômica das Nações Unidas para a América Latina e Caribe

Conselho Federal de Contabilidade

Certified Public Accountant

Comitê de Pronunciamentos Contábeis

Conselho Regional de Contabilidade

Comissão de Valores Mobiliários

Demonstração dos Fluxos de Caixa

Departamento Intersindical de Estatística e Estudos Socioeconômicos

Demonstração de Mutações de Patrimônio Líquido

Demonstração de Resultado do Exercício

Estados Unidos da América

Financial Accounting Standards Board

Fundo de Direitos Creditórios

Faculdade de Economia, Administração e Contabilidade

Federação Brasileira de Bancos

Fundação Getúlio Vargas

Financiadora de Estudos e Projetos

Fundação Instituto de Pesquisas Contábeis, Atuariais e Financeiras 
GAAP

IBGE

IAS

IASB

IASC

IBRACON

IFRS

IFs

ITG

LM

MPEs

MPMEs

MQO

N/A

NBC T

NE

NPAE

OCDE

ONU

PAC

PEPS

PF

PIB

PIS

PJ

PMEs

POLS

PPGCC

$\mathrm{RCO}$

ROE

ROSC

SEBRAE

SEC

SEMEAD
Generally Accepted Accounting Principles

Instituto Brasileiro de Geografia e Estatística

International Accounting Standards

International Accounting Standards Board

International Accounting Standards Committee

Instituto dos Auditores Independentes do Brasil

International Financial Reporting Standards

Instituições Financeiras

Interpretação Técnica Geral

Lagrange Multiplier

Micro e Pequenas Empresas

Micro, Pequenas e Médias Empresas

Mínimos Quadrados Ordinários

Não Aplicável

Norma Brasileira de Contabilidade - Técnica

Notas Explicativas

Non-Publicly Accountable Entities

Organização para a Cooperação e Desenvolvimento Econômico

Organização das Nações Unidas

Programa de Aceleração do Crescimento

Primeiro que entra, primeiro que sai

Pessoa Física

Produto Interno Bruto

Programa de Integração Social

Pessoa Jurídica

Pequenas e Médias Empresas

Pooled Ordinary Least Squares

Programa de Pós-Graduação em Controladoria e Contabilidade

Revista de Contabilidade e Organizações

Return over Equity

Report on Observance of Standards and Codes

Serviço de Apoio às Micro e Pequenas Empresas

Securities and Exchange Commission

Seminários em Administração 
SCR

SFAC

SFN

SMEs

SSRN

WBI

UEPS

UK

UNCTAD

US

USP
Sistema de Informações de Crédito do Banco Central

Statement of Financial Accounting Concepts

Sistema Financeiro Nacional

Small and Medium-sized Entities

Social Science Research Network

The World Bank Institute

Último que entra, primeiro que sai

United Kingdom

Conferência das Nações Unidas para Comércio e Desenvolvimento

United States of America

Universidade de São Paulo 


\section{LISTA DE TABELAS}

Tabela 1 Empresas, pessoal ocupado, total e assalariado, e salários e outras remunerações, segundo porte da empresa - Brasil - 2010 ..................... 55

Tabela 2 Ranking de Bancos por Crédito para Médias Empresas em 2011.......... 68

Tabela 3 Estatísticas Descritivas das Variáveis de 2009..................................... 102

Tabela 4 Estatísticas Descritivas das Variáveis de 2010................................... 102

Tabela 5 Estatísticas Descritivas das Variáveis de 2011 .................................... 103

Tabela 6 Teste de Mann-Whitney (Amostra Total - 2010 e 2011)......................... 108

Tabela 7 Teste de Mann-Whitney (Agronegócios - 2010 e 2011).......................... 109

Tabela 8 Teste de Mann-Whitney (Indústria de Base - 2010 e 2011).................... 110

Tabela 9 Teste de Mann-Whitney (Serviços - 2010 e 2011).................................. 111

Tabela 10 Teste de Mann-Whitney (Ind. de Bens de Consumo - 2010 e 2011)....... 112

Tabela 11 Teste de Mann-Whitney (Comércio - 2010 e 2011)............................... 113

Tabela 12 Teste de Mann-Whitney (Centro-Oeste - 2010 e 2011).......................... 115

Tabela 13 Teste de Mann-Whitney (Norte-Nordeste - 2010 e 2011)....................... 116

Tabela 14 Teste de Mann-Whitney (Sudeste - 2010 e 2011).................................. 117

Tabela 15 Teste de Mann-Whitney (Sul - 2010 e 2011)....................................... 118

Tabela 16 MQO agrupado, usando 230 observações, incluídas 115 unidades de corte transversal e comprimento da série temporal de 2 anos................ 121

Tabela 17 Parâmetros das transformações Box-Cox das variáveis.......................... 123

Tabela 18 MQO agrupado com dados ajustados, usando 230 observações, incluídas 115 unidades de corte transversal e comprimento da série temporal de 2 anos................................................................... 124

Tabela 19 Fatores de Inflação da Variância (VIF) das variáveis............................ 125

Tabela 20 Testes de Diagnóstico de Painel............................................................ 126

Tabela 21 Painel de Efeitos Fixos com dados ajustados, usando 230 observações incluídas 115 unidades de corte transversal e comprimento da série temporal de 2 anos 


\section{LISTA DE FIGURAS}

Figura 1 Posição do sistema jurídico brasileiro (países que acompanham o sistema jurídico codificado)

Figura 2 Teste de Hipótese para diferença de medianas unilateral (Mann Whitney) 


\section{LISTA DE QUADROS}

Quadro 1 Componentes do Ambiente das Demonstrações Contábeis....................... 22

Quadro 2 Características da divulgação das categorias de pesquisa.......................... 23

Quadro 3 Diferenças entre as IFRS para PMEs e as IFRS completas...................... 41

Quadro 4 Similaridades e Diferenças (US/GAAP, Full IFRS, IFRS for SMEs)....... 44

Quadro 5 Resumo dos Resultados dos Testes Não Paramétricos por Setor de Atividade ................................................................. 114

Quadro 6 Resumo dos Resultados dos Testes Não Paramétricos por Região 119 


\section{LISTA DE GRÁFICOS}

Gráfico 1 Distribuição percentual do pessoal ocupado total, por pessoal assalariado, e sócios e proprietários, segundo o porte da empresa - Brasil 2010 56

Gráfico 2 Evolução do volume de crédito em relação ao PIB (\%) - Brasil Mar/2007 a Jan/2013 - Pessoas Jurídicas e Pessoas Físicas

Gráfico 3 Evolução do volume de crédito em relação ao PIB (\%) - Brasil Mar/2007 a Jan/2013 - Tipo de Recursos (Livres e Direcionados) 64

Gráfico 4 Crédito Doméstico ao Setor Privado de países selecionados (em \% do PIB) - 2011 65

Gráfico 5 Spread bancário no Brasil e países selecionados (Taxa de Empréstimo menos Taxa de Depósito, \%) - 2010 66

Gráfico 6 Distribuição Geográfica da Amostra (Percentual). 104

Gráfico 7 Distribuição da Amostra por Setor da Economia conforme critério da Revista M\&M Exame (2012) em quantidade de empresas..................... 104

Gráfico 8 Distribuição da Amostra por Setor da Economia Adaptada (Percentual).. 105

Gráfico 9 Evolução das Médias dos Índices de Disclosure e Adoção do Padrão CPC (Distribuição Setorial entre 2009-2011) 106

Gráfico 10 Evolução das Médias dos Índices de Disclosure e Adoção do Padrão CPC (Distribuição Regional entre 2009-2011) 106 


\section{INTRODUÇÃO}

\subsection{Objetivos da pesquisa}

Assuntos que envolvem a seara da contabilidade internacional tem sido objeto de estudo intenso nos últimos anos, principalmente com os avanços decorrentes da globalização e o advento de companhias e profissionais transnacionais, não obstante, ainda há muitas lacunas a serem preenchidas pela Academia, tanto local quanto internacionalmente, uma delas é o universo da pesquisa voltada para as microempresas, pequenas e médias empresas (MPMEs).

O tema desse trabalho se refere a um dos diversos efeitos das alterações nos critérios contábeis propostos pelo IASB (International Accounting Standards Board), mais especificamente da convergência contábil para pequenas e médias empresas (PMEs). Procurou-se investigar junto às referidas entidades e às instituições bancárias com as quais elas mantêm relacionamento, o efeito dessas mudanças nos padrões contábeis sobre os custos dos recursos para crédito bancário a PMEs no Brasil.

Nesse sentido, primeiramente foi necessário discutir alguns conceitos que concernem às origens da regulamentação contábil encontrados na literatura da Teoria da Contabilidade para alicerçar as discussões sobre assimetria informacional, dentre eles os próprios objetivos da contabilidade, as diferenças existentes entre ambientes regulatórios ( "Common Law " " e "Code $L a w^{2}$ "), os usuários da informação contábil, assim como, os fundamentos pertinentes à formulação de normas contábeis, como por exemplo, a relação custo-benefício de uma norma contábil.

Ainda no polo teórico, analisar os aspectos que concernem o fenômeno da divulgação de informações contábeis, no que se referem a incentivos e efeitos, assim como sua relação com a qualidade da informação, foi de fundamental importância para a formação dos constructos estudados nesse trabalho.

${ }^{1}$ Direito consuetudinário, cuja origem da regulamentação está mais ligada aos costumes e tradições, normalmente adotado em países que fizeram parte do império britânico, é dizer, Estados Unidos, Canadá, Austrália, Nova Zelândia, Malásia, além do próprio Reino Unido, entre outros (Lopes \& Martins, 2005, p.52).

${ }^{2}$ Direito romano, em que as normas emanam do texto legal, normalmente praticado em países que tiveram influência do império romano e depois sob influência francesa, é dizer, França, Alemanha, Itália, Portugal, Espanha na Europa e suas colônias na América Latina, entre outros (Ibid., p.52) 
Em seguida fez-se a exposição de toda a cronologia do desenvolvimento dos trabalhos realizados pelo IASB nas IFRS (International Financial Reporting Standards) voltadas para PMEs, assim como seus objetivos, contextualização e alcance, desde os "Discussion Papers"3, passando pelos "Exposure Drafts", até chegar à norma IFRS for SMEs (Small and Mediumsized Entities) propriamente dita, e sua recepção pelo CPC (Comitê de Pronunciamentos Contábeis) em 2009.

A partir daí, descrevem-se, por meio das normas emitidas e manuais apropriados, as particularidades técnicas da norma para empresas de porte reduzido, trazendo as principais similitudes e diferenças para as IFRS completas (exigidas para as sociedades abertas e empresas de grande porte, definidas por $\mathrm{Lei}^{5}$ ), assim como alguns aspectos referentes aos antigos padrões contábeis, tudo isso para contextualizar as mudanças e começar a trazer alguns problemas à tona.

Segundo o IASB, há consequências vantajosas que justificam a adoção de um padrão internacional de contabilidade, como por exemplo: (i) aumento da comparabilidade das informações financeiras, elucidando as comparações efetuadas por investidores, mutuantes e outros; (ii) possibilidade de redução das incertezas que influenciam a alocação eficiente e precificação de capital, não somente beneficiando aqueles que oferecem capital de terceiros ou capital próprio, mas também as empresas que buscam capital, por reduzir incertezas que afetam os custos; (iii) facilidade de instrução e treinamento de colaboradores, e, (iv) melhora da consistência em termos de qualidade de auditoria (IBRACON, 2010, p.20).

No que se refere particularmente à tomada de decisões de concessão de crédito, estudos encontraram evidências de que a qualidade das demonstrações financeiras e a transparência financeira afetam positivamente a eficiência de alocação de capital em mercados emergentes (Chen et al.,2010; Hope et al., 2010). Esses trabalhos são mencionados no discurso de Paul Pacter (2010, Webcast Part 1 Chapter 2), membro do IASB responsável por IFRS para PMEs, como evidências encontradas de que informação com melhor qualidade produz efeito no acesso

\footnotetext{
${ }^{3}$ Documentos para Discussão.

${ }^{4}$ Minutas de Exposição.

${ }^{5}$ Lei 11.638/07.
} 
ao capital das pequenas e médias empresas, o que foi apontado como uma das razões para adoção de IFRS para PMEs. Na mesma linha de pensamento, há artigos como o de Zambaldi et al. (2011), que estudou o maior acesso ao crédito por conta do cadastro positivo de credores e o mercado de crédito para pequenas e médias empresas no Brasil.

No entanto, encontram-se na literatura alguns questionamentos quanto à necessidade de se estabelecer um padrão contábil internacional para pequenas e médias empresas, dentre eles: i) desproporcionalidade de custos de implementação de um novo padrão (Masca \& Gall, 2008; Bertoni \& De Rosa, 2010; Fitzpatrick \& Frank, 2009; Herman, 2010; Litjens et al., 2012); ii) capacidade técnica dos contadores das PMEs e dos demais stakehoders ${ }^{6}$ acerca da interpretação e julgamento de normas baseadas em conceitos e princípios (Dantas et al., 2010; Seifert \& Lindberg; 2010; Herman, 2010); iii) real necessidade de comparabilidade de demonstrações financeiras (Masca \& Gall, 2008; Herman, 2010); iv) e por fim, a identificação dos usuários das informações contábeis e suas necessidades, bem como as questões envolvendo o tamanho das pequenas empresas, especialmente para as microempresas, e a influência da legislação tributária (Bertoni \& De Rosa, 2010; Jermakovicz \& Epstein, 2010; Lenormand, Poulard \& Touchais, 2012; Christie \& Brozovsky, 2010), devidamente explorados na revisão bibliográfica.

Portanto, além dos eventuais benefícios da adoção das IFRS para PMEs, também deveriam ser considerados todos os custos da regulação contábil, que segundo Iudícibus e Lopes (2004), "Incluem custos diretos (recursos consumidos no processo de geração das normas e observância por parte das firmas) e indiretos (decisões de investimento, produção e financeiras das firmas), que são tão importantes quanto os primeiros” (pp. 248-249).

Ademais é preciso levar em consideração o estudo de Weffort (2005) sobre fatores que influenciam a harmonização contábil, quando diz que não necessariamente as harmonizações de fato e de direito são coincidentes, logo, a obrigatoriedade de padrões contábeis por meio de normas contaria a favor da harmonização de direito, entretanto, fatores como a fraqueza na aplicação e fiscalização das normas ou aspectos culturais poderiam não conduzir a uma harmonização de fato (p. 63).

Depois de revisitada a norma, procurou-se contextualizar a micro, pequena e média empresa no cenário nacional, com a intenção de expor suas principais características em termos de

\footnotetext{
${ }^{6}$ Partes interessadas.
} 
quantidade de empresas e volume de massa salarial ocupada, evidenciando a participação do setor na economia como um todo. Assim como foi contextualizado o crédito no país, primeiro em termos nacionais, depois com foco para empresas de porte reduzido.

Em seguida, buscou-se identificar as diversas relações entre a contabilidade (dentre as diversas fontes de informação dos tomadores de crédito), empresas de pequeno e médio porte, e análise de concessão de crédito pelas instituições financeiras, por meio de pesquisas anteriormente realizadas. Primeiramente examinaram-se as combinações tomadas duas a duas, e por fim todas as variáveis estudadas em conjunto.

A restrição ao crédito vem sendo apontada como uma das dificuldades enfrentadas por PMEs (Deliotte, 2009, 2012a; Zambaldi et al., 2011; SEBRAE, 2007; Carvalho \& Abramovay, 2004; Bedê, 2004; Ross, 2000; Kassai \& Kassai, 2001; Kassai \& Casa Nova, 2006), a contabilidade até então utilizada tão somente para fins tributários começa a mudar o foco da sua finalidade não apenas para ajudar na gestão dos negócios, mas principalmente para trazer transparência a essas entidades.

A partir dessa colocação, acredita-se que um conjunto de demonstrações contábeis mais confiáveis, mais transparentes e mais próximas da realidade das empresas possa interferir nas decisões de concessão de crédito bancário (Malhotra et al., 2007; Souza et al., 2006; Zuelch \& Burghardt, 2010).

Desse modo, o presente trabalho também tem como objetivo investigar como as instituições financeiras ${ }^{7}$ no mercado brasileiro levam em consideração as informações contábeis de pequenas e médias empresas no momento da análise de concessão de crédito.

Será que os benefícios justificam a adoção de uma contabilidade com padrão internacional considerando os custos associados a essa adoção? Para isso, propõe-se no presente trabalho responder ao seguinte questionamento: Qual é a relação entre a adoção de um padrão contábil internacional para pequenas e médias empresas (CPC-PME) no Brasil e o custo do crédito concedido pelas instituições financeiras?

\footnotetext{
${ }^{7}$ Instituições financeiras neste trabalho referem-se a bancos múltiplos e comerciais.
} 
Apesar de a adoção do CPC-PME ter como um de seus objetivos proporcionar maior transparência e qualidade às informações contábeis das empresas de menor porte, não é evidente que haverá benefícios tangíveis a essas entidades, no que se refere a melhores custos em termos de crédito bancário.

Logo, para responder à questão de trabalho, apoia-se na teoria da divulgação e nos objetivos propostos pelos reguladores, pelos quais, podem ser elaboradas hipóteses empiricamente testáveis, em que informações contábeis de qualidade justificariam uma redução de custos. Seguem abaixo as hipóteses elaboradas a serem testadas neste trabalho:

Hipótese I (HI): Empresas com melhor qualidade da informação contábil captam créditos bancários em melhores condições de custo que empresas com pior qualidade das informações contábeis.

\section{Hipótese II (HII): Empresas que evidenciam seu padrão contábil baseado nas nor- mas emanadas pelo CPC captam créditos bancários em melhores condições de custo que empresas que não o evidenciam.}

Como objetivo secundário, foram observadas a prática de algumas empresas de pequeno e médio porte no Brasil nos critérios de divulgação de suas demonstrações contábeis, para visualizar o atual estágio de implementação da CPC-PME no país, assim como se investigou como as instituições financeiras no mercado brasileiro levam em consideração as informações contábeis de pequenas e médias empresas no momento da análise de concessão de crédito.

Não será possível fazer uma generalização para todas as PMEs, uma vez que elas são muito heterogêneas, mas será possível identificar algumas tendências de adoção de práticas contábeis.

O cruzamento entre técnicas de coleta de dados (entrevistas e análises de balanços) poderá induzir a conclusões sobre as mudanças de fato e efeitos provocados pela adoção de um novo padrão contábil. 


\subsection{Justificativas da pesquisa}

Este trabalho pode ser justificado primeiramente pela carência na academia brasileira de estudos relacionados a empresas de pequeno e médio porte, dada a sua relevância na economia nacional. Segundo Floriano (2010), as pequenas e médias empresas

[...] representam, para o País, a geração de emprego, inovação, flexibilidade, diversificação da competição e uma parte considerável do processo produtivo. Para o Brasil, as PMEs são ainda mais importantes, pois a possibilidade de estas atenderem às necessidades locais, pela flexibilidade e conhecimento local, é muito maior do que a das grandes empresas, [...] (p. 11),

assim como, no que tange a aspectos das normas internacionais de contabilidade (que também pouco foram estudadas no âmbito das PMEs), principalmente no que se refere a pesquisas com maior profundidade, conforme cita Dantas et al. (2010), “[...]. Não há evidências, porém, de estudos que avaliem os aspectos mais filosóficos dos modelos de normatização, destacando os benefícios, os custos, as oportunidades e os riscos da alteração do modelo de normatização para baseado em princípios." (p. 23).

Segundo Ribeiro Filho, no que se refere à pesquisa contábil, o Brasil dispõe quase que exclusivamente de demonstrações contábeis de companhias abertas, que publicam seus resultados, logo os estudos se limitam à minoria das empresas brasileiras, considerando todo o universo corporativo. O acesso mais amplo a dados contábeis de PMEs no Brasil é bastante difícil (citado por Girotto, 2010, p. 19).

De outro lado, sob o ponto de vista da sociedade, o estudo pode provocar discussões sobre a real necessidade em se adotar um padrão de normas internacionais no âmbito das PMEs, e sobre um eventual planejamento para formação de profissionais capacitados, uma vez que o uso de um novo padrão de contabilidade que atinge a maior parte dos ramos da economia nacional, certamente deveria envolver investimento em ensino contábil. A capacitação em IFRS seria de fundamental importância para a promoção da educação dos atuais profissionais, dos professores de contabilidade e dos futuros estudantes, para a devida adequação dos interessados aos padrões contábeis internacionais. 
Os órgãos normatizadores do Brasil se anteciparam a diversos outros países de economia avançada, na adoção das IFRS para PMEs, com a aprovação do CPC para PMEs, transformada em norma no final do ano de 2009, no entanto, diversos países ainda estudam a viabilidade de aplicação da norma internacional para PMEs, na sua totalidade ou parcialmente.

De acordo com Girotto (2010), apesar de regras específicas para as PMEs não serem de aplicação direta por parte de entidades que fazem intermediação financeira, estas sob supervisão do Banco Central do Brasil, este órgão destaca que como ele não normatiza sobre o tema, cabe às instituições contábeis elegerem as melhores fontes de informação para avaliar o risco das operações, pois parte dessa avaliação é constituída da análise das demonstrações financeiras, além de outros fatores como situação cadastral, setor de atividade econômica, garantias, natureza e finalidade do crédito e valor do financiamento (p. 14).

É nesse sentido que órgãos, como por exemplo, o Banco Central, também estudam a aplicação de instrumentos que incentivem a redução de assimetrias no sistema financeiro nacional. A autarquia, na qualidade de supervisora das instituições financeiras bancárias visa a promover um sistema inclusivo, e tem como uma de suas motivações a redução das diferenças sociais para desenvolvimento econômico da nação, uma vez que permite aos empreendedores um acesso mais amplo ao crédito e a produtos financeiros, expandindo assim as oportunidades econômicas (BCB, p.13).

O relatório de inclusão financeira do Banco Central, afirma que o órgão, ao atuar na promoção da eficiência e da inclusão financeira, tem por fim reduzir a assimetria na distribuição dos serviços financeiros, garantir sua adequabilidade e sustentabilidade. Para tanto, é necessária a adoção de medidas relativas tanto à oferta quanto à demanda de serviços financeiros. Em relação à oferta, é importante induzir a redução de assimetrias regionais na provisão de serviços financeiros, a adequação dos serviços ofertados às necessidades dos usuários e a sustentabilidade do processo. Quanto à demanda, é necessário conferir atenção à educação financeira e à proteção aos usuários, de forma a garantir que a utilização de serviços financeiros seja sustentável e benéfica a todos (Ibid., p.16).

Nesse sentido, a possibilidade de aumento de capacidade creditícia de PMEs se encaixaria muito bem no perfil de indução da oferta de serviços financeiros de forma sustentável, 
visando a garantia de criação de empregos ao longo do tempo, em um setor da economia que é responsável por boa parte da massa salarial do país.

Ademais, a pesquisa contribui para as atividades de supervisão bancária, realizadas pelo BACEN, na medida em que fornece novos subsídios sobre os diversos fatores ligados à informação contábil que podem interferir na concessão de crédito bancário às pequenas e médias empresas, que podem influenciar aspectos impactantes nos processos de regulação e supervisão prudencial do sistema financeiro nacional (SFN).

\subsection{Estrutura da pesquisa}

Esta dissertação está estruturada em cinco capítulos, além das referências bibliográficas, da lista de abreviaturas e siglas, lista de tabelas, lista de ilustrações (gráficos, figuras e quadros), e, dos apêndices.

Após essa breve introdução, segue-se a revisão da literatura utilizada, englobando os aspectos que envolveram a criação da nova norma internacional para pequenas e médias empresas no âmbito internacional, os conceitos trazidos da teoria da contabilidade e as discussões sobre sua implantação no Brasil e no mundo; em seguida descreve-se a conceituação de PMEs, sua contextualização no país e o relacionamento dessas entidades com as instituições bancárias brasileiras, assim como são trazidas para discussão as pesquisas realizadas dentro dessa temática.

A seguir, apresenta-se a abordagem metodológica empregada na pesquisa, e em seguida são elencados os resultados obtidos na pesquisa de campo, tanto da análise quantitativa dos conteúdos das demonstrações financeiras das empresas de pequeno e médio porte, como da análise qualitativa advinda das entrevistas às instituições financeiras bancárias.

Por fim o trabalho é encerrado com as conclusões obtidas do cruzamento das informações coletadas nos trabalhos de campo com o referencial teórico. 


\section{REVISÃO DA LITERATURA}

\subsection{Aspectos teóricos sobre regulação e divulgação contábil}

\subsubsection{Origens da regulação contábil}

Martins, Diniz e Miranda (2012) afirmam que foi na Europa Continental (países latinos e germânicos), onde predominava o direito romano, que começou a normatização em contabilidade, mais especificamente em 1673, com o Código Comercial Francês. Tratava-se de uma contabilidade caracterizada pelo conservadorismo, em que o reconhecimento de receitas era postergado e as despesas eram reconhecidas o mais rápido possível (pp. 44-45).

Já na Inglaterra, a normatização contábil surgiu para atender os interesses de credores e investidores, também conservadora, porém mais com sentido de prudência. A partir da Revolução Industrial na segunda metade do século XVIII, a captação feita por emissão de ações começou a se alavancar, fazendo com que as regras contábeis passassem a atender o interesse desses investidores. Havia então dois focos de atenção da contabilidade, uma voltada para o banqueiro (credor) e outra voltada para o investidor (Ibid., p. 45).

Quanto à presença do Fisco, os autores continuam a rever os eventos históricos, e dizem que, a partir do século passado, os Estados passaram a tributar sobre os lucros contábeis. Os alemães, por sua vez, mantiveram a mesma ideologia conservadora, que protegia os credores, para pagar os impostos, ou seja, na medida em os lucros eram postergados, os tributos também eram adiados, logo eles adequaram o Fisco à contabilidade. Já na Itália e na França, o empresariado não se sobrepôs ao Fisco, e os Estados começaram a normatizar pensando muito mais nas suas arrecadações. No caso dos ingleses, eles conseguiram manter a contabilidade para os investidores e criaram outra para fins tributários (Ibid., pp. 46-47).

\subsubsection{A regulação contábil sob o olhar da Teoria da Contabilidade}

Segundo Lopes e Martins (2005), no que se refere à regulação contábil, em países que adotam o modelo de "Common Law”, a contabilidade escapa da influência governamental, a autoridade é transferida para órgãos de iniciativa privada, como por exemplo, o caso do FASB ${ }^{8}$ nos Estados Unidos da América. Quando há a prevalência de uma estrutura voltada ao modelo

\footnotetext{
${ }^{8}$ Financial Accounting Standards Board
} 
“Code Law”, há regulação direta pelo governo central, caso do Ministério de Finanças no Japão (pp. 58-59).

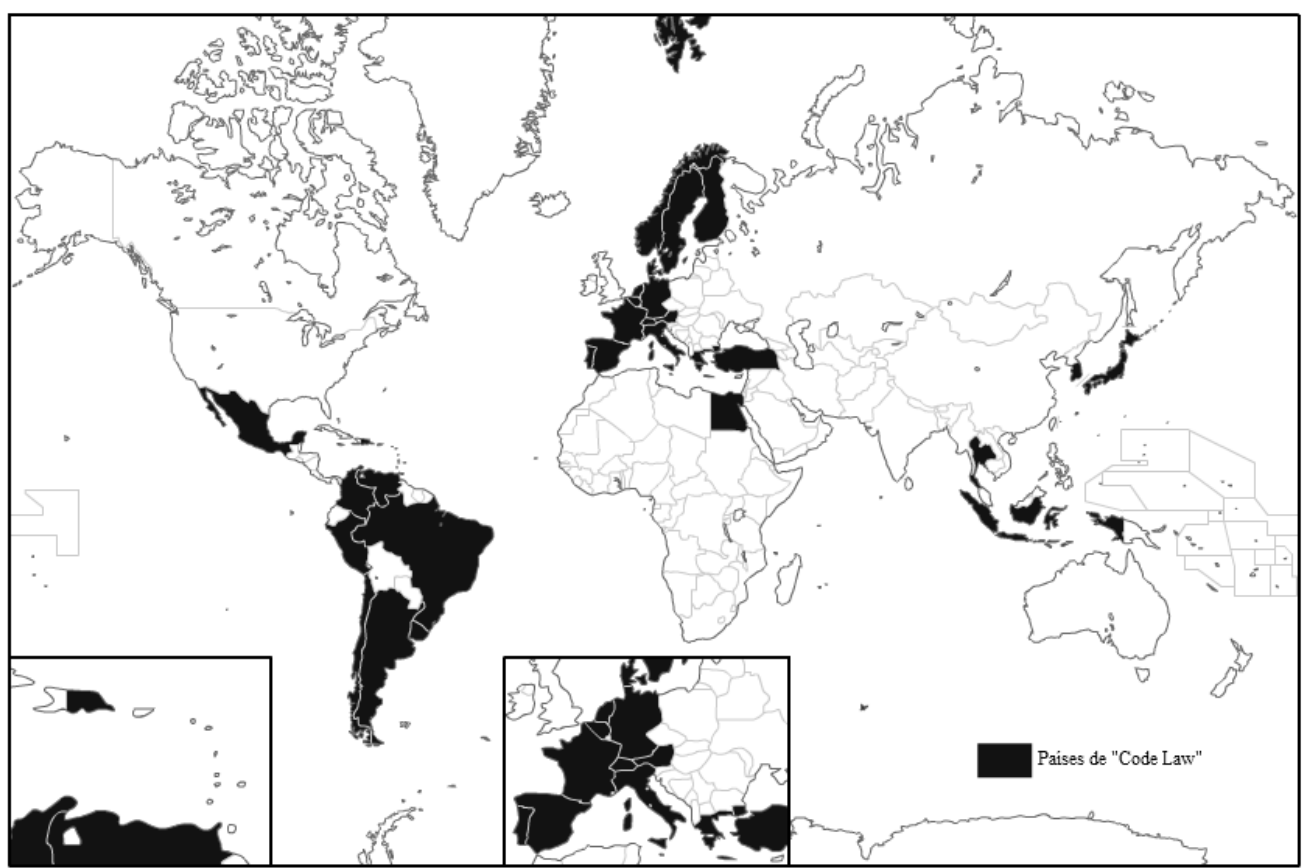

Figura 1 - Posição do sistema jurídico brasileiro (países que acompanham o sistema jurídico codificado $)^{9}$.

Fonte: Weffort (2005), p. 99

Segundo Weffort (2005), o sistema jurídico do Brasil pode ser considerado como codificado (ou romano-germânico), ou "Code Law", pelo seu desenvolvimento histórico, conforme apresentado na figura 1, em que são demonstrados os países que acompanham esse sistema (p.98-100). Argentina, Chile, Colômbia, México, Peru, República Dominicana, Uruguai e Venezuela nas Américas. Egito na África. Cingapura, Coréia do Sul, Tailândia e Japão na Ásia. Espanha, Portugal, França, Itália, Grécia, Turquia, Suíça, Áustria, Alemanha, Holanda, Bélgica, Suécia, Finlândia, Noruega e Dinamarca na Europa.

Hendriksen e Van Breda (2010) dizem que a regulação contábil surge quando o mercado falha de alguma maneira, ou seja, quando mercado não é capaz de oferecer a quantidade socialmente ótima de informação, nesse momento então há assimetria informacional, e assim, a regulação surge em proteção ao interesse público (p. 162).

${ }^{9} \mathrm{Na}$ análise foram considerados apenas os países constantes na relação das 100 maiores economias do mundo segundo a UNCTAD, 2002. 
Inclusive, Lopes e Martins (2005) consideram que as diferenças informacionais estão no cerne do surgimento da contabilidade (p. 30), para eles "Sem assimetria informacional não há utilidade para a própria contabilidade" (Ibid. p. 32).

Um segundo argumento para o surgimento da regulação, segundo Hendriksen e Van Breda (2010), é que ela surge da existência de um bem público, nesse caso a informação contábil, que apesar da existência de free-rider ${ }^{10}$, deve ser disponibilizada à sociedade gerenciada pelo governo. E por fim, eles completam com o terceiro argumento para a origem da regulação que consiste na ausência de comparabilidade, conjugada a uma necessidade de facilitar a elaboração de predições e tomada de decisões por credores, investidores e outros interessados (pp. 162-163).

Na mesma linha da informação como um bem público, segundo Weil (2002, citado por Murcia e Santos, 2009): "existiria um gap entre o que as empresas estão dispostas a evidenciar e o que os usuários efetivamente demandam, e essa seria justamente a razão da regulação: exigir as informações que os usuários necessitam e que as empresas não estão dispostas a divulgar voluntariamente." (p. 7).

Segundo Yamamoto e Salotti (2006, pp. 11/12), a forma como a divulgação deve ser tratada, se voluntária ou obrigatória, suscita muitas discussões na Academia, há aqueles favoráveis à regulação que argumentam que as empresas não fornecem informações suficientes para seus usuários, pois estas podem favorecer seus concorrentes, empregados e outros, já os defensores da divulgação voluntária argumentam que há estímulos para o fornecimento das informações capazes de satisfazer os investidores. Observa-se que regulamentação é reativa e está sempre evitando a ocorrências das últimas fraudes, enquanto a divulgação voluntária é proativa.

Logo, uma vez observado o surgimento da contabilidade, é possível entender melhor quais são seus objetivos. O IASB seguiu um foco pragmático que se caracterizava, segundo Hendriksen e Van Breda (1999), por um enfoque pelo qual a divulgação financeira deveria fornecer informações que fossem úteis para os usuários que visassem à tomada racional de decisões de investimento, de crédito e outras semelhantes, conforme estabelecido na própria

\footnotetext{
${ }^{10}$ Aqueles que desfrutam dos benefícios sem pagar por eles.
} 
estrutura conceitual da norma ${ }^{11}$ (p. 93). É o que consta da estrutura conceitual do CPC (2010), a norma diz que:

[...] o objetivo das demonstrações contábeis é fornecer informações sobre a posição patrimonial e financeira da entidade (Balanço Patrimonial), sobre seu desempenho em um determinado período (Demonstração do Resultado) e sobre as modificações na sua posição financeira (Demonstração dos Fluxos de Caixa, no Brasil, a partir de 2008), informações essas que sejam úteis a um grande número de usuários em suas avaliações e tomadas de decisão econômica (p. 8).

Lopes e Martins (2005), quanto à essência do objetivo citado acima, dizem que: "verifica-se que a contabilidade tem função clara e objetiva de servir às necessidades dos usuários". (p. 125).

Hendriksen e Van Breda (2010), ao comentar os objetivos do Referencial Conceitual, dizem que: "Pode-se fazer afirmações sobre os tipos de usuários e os usos da informação, mas sem evidências concretas é difícil tornar conclusivas tais afirmações. Em consequência, o referencial não tem sido o motor do estabelecimento de padrões que seus proponentes haviam esperado" (p. 95).

Beaver (1998) ao se referir aos usuários da informação contábil, diz que a atmosfera do conjunto desses usuários se trata de um ambiente constituído de vários grupos, que podem estar envolvidos entre si de alguma maneira, mas com interesses diversos. Além do mais, cada grupo não é homogêneo, como são retratados no quadro 1 abaixo, logo demonstrações contábeis podem induzir a várias consequências e certamente vários componentes irão reagir de uma maneira diferente a estas consequências (p. 13).

${ }^{11}$ The objective of financial statements is to provide information about the financial position, performance and changes in financial position of an entity that is useful to a wide range of users in making economic decisions (IASB, 2009, p.18). 
Quadro 1 - Componentes do Ambiente das Demonstrações Contábeis

\begin{tabular}{|c|l|}
\hline \multirow{3}{*}{ I - Investidores } & A - Diversificados vs. Não Diversificados \\
& B - Ativos vs. Passivos \\
C - Profissionais vs. Não Profissionais & A - Analistas Financeiros \\
II - Intermediários da Informação & B - Agências de Rating de Títulos \\
& C - Agências de Rating de Ações \\
& E - Consultores de Investimentos \\
\hline \multirow{3}{*}{ III - Reguladores } & A - FASB (IASB, CPC) \\
& B - SEC (CVM) \\
& C - Congresso \\
\hline IV - Gestores & A - Empresas de Grande Porte vs. Empresas de Pequeno Porte \\
& B - Empresa de Capital Aberto vs. Empresas de Capital Fechado \\
\hline \multirow{2}{*}{ V - Auditores } & A - Empresas Internacionais vs. Empresas Locais \\
& B - Registrados na SEC (CVM) vs. Não Registrados na SEC \\
& (CVM) \\
\hline
\end{tabular}

Fonte: Cardoso et al. (2009, p. 777) adaptado de Beaver (1998, p.13)

Ao concluir seu capítulo de trata da regulação contábil, Beaver (Ibid.) afirma que a regulação das demonstrações financeiras é uma escolha social por conta da sua potencialidade em produzir consequências nos usuários, efeitos que irão exigir considerações de especialistas em contabilidade. A perspectiva da escolha social flui naturalmente da visão do sistema de reporte financeiro como um sistema de informação para um ambiente de várias pessoas. Essa perspectiva pode direcionar para mudanças dramáticas nas demonstrações financeiras, e estas podem ser vistas como uma forma de revolução da contabilidade ${ }^{12}$ (p. 172).

Portanto, percebe-se claramente a existência de argumentos bastante plausíveis na teoria da contabilidade sobre a necessidade da regulação contábil no que tange à divulgação da informação contábil.

${ }^{12}$ Financial reporting regulation is a social choice because of the potentiality diverse effects or consequences of regulation on the constituencies. These effects will typically entail considerations beyond those of accounting expertise. This social choice perspective naturally follows from viewing a financial reporting system in a multiperson setting. This perspective can lead to potentially dramatic changes in financial reporting, and these changes can be a form of accounting revolution. 


\subsubsection{Teoria da Divulgação}

Complementarmente aos aspectos trazidos da teoria contábil clássica, vejamos alguns aspectos referentes à teoria da divulgação, cujo principal objetivo é explicar os fenômenos relacionados à divulgação da informação financeira (Yamamoto \& Salotti, 2006, p. 16).

Verrecchia (2001, p. 99), em sua tentativa de estabelecer uma ideia preliminar de teoria da divulgação, apresenta uma classificação de modelos de pesquisa para entendimento do fenômeno da evidenciação das informações contábeis. Neste sentido, sua taxonomia sugere três categorias de pesquisa no assunto: (a) divulgação baseada em associação, que consiste no estudo dos efeitos exógenos da evidenciação contábil nas atitudes dos investidores principalmente nos preços e volume de negociação das ações ${ }^{13}$, (b) divulgação baseada na discricionariedade ou julgamento, que trata de estudos em que a evidenciação é considerada como endógena, em que existem incentivos pelos quais os gestores decidem divulgar ou esconder a informação ${ }^{14}$, e por fim, (c) divulgação baseada na eficiência, que estuda escolhas incondicionais de evidenciação, em que os agentes fazem escolha em um ambiente de maximização de bem-estar social e redução de assimetrias ${ }^{15}$.

Quadro 2 - Características da divulgação das categorias de pesquisa

\begin{tabular}{|c|c|c|}
\hline \multirow{2}{*}{ Categorias de Pesquisa } & \multicolumn{2}{|c|}{ Características da Divulgação } \\
\cline { 2 - 3 } & $\begin{array}{c}\text { Momento de Ocorrência } \\
\text { da Divulgação (ex ante ou ex post) }\end{array}$ & $\begin{array}{c}\text { Processo de Divulgação } \\
\text { (endógeno ou exógeno) }\end{array}$ \\
\hline Associação & ex post & Exógeno \\
\hline Julgamento & ex post & Endógeno \\
\hline Eficiência & ex ante & Não aplicável \\
\hline
\end{tabular}

Fonte: Yamamoto \& Salotti (2006, p. 18)

${ }^{13}$ The first category of research is work whose primary concern is how exogenous disclosure is associated with, or related to, the change or disruption in the activities of investors who compete in capital market settings as individual, welfare-maximizing agents. I dub this research 'association-based disclosure'. The distinguishing feature of work in this category is that it studies the effects of exogenous disclosure on the aggregate or cumulative change in investors' actions, primarily through the behavior of asset equilibrium prices and trading volume.

${ }^{14}$ The second category is work that examines how managers and/or firms exercise discretion with regard to the disclosure of information about which they may have knowledge. I dub this research "discretionary-based disclosure'. The distinguishing feature of work in this category is that it treats disclosure as endogenous by considering managers' and/or firms' incentives to disclose information known to them; typically this is done in the context of a capital market setting in which the market is characterized as (simply) a single, representative consumer of disclosed information.

${ }^{15}$ The third category is work that discusses which disclosure arrangements are preferred in the absence of prior knowledge of the information, that is, ex ante. I dub this research "efficiency-based disclosure". The distinguishing feature of work in this category is that it examines unconditional disclosure choices; typically this is done in the context of a capital market setting in which the actions of individual, welfare maximizing agents are endogenous. 
Yamamoto (2005, p.11) examinou os aspectos da divulgação da informação contábil no Brasil sob o prisma da primeira categoria, baseada em associação, ou seja, verificar os efeitos nos preços das ações no mercado de capitais a partir da divulgação voluntária de determinados itens e explicar quais as razões econômicas para que determinada informação seja divulgada voluntariamente, e concluiu que as empresas com maior nível de divulgação são aquelas que apresentam mais qualidade na divulgação de informações, em que qualidade é estabelecida pelo impacto positivo da divulgação nos preços das ações (Ibid., p. 105).

Salotti (2005, p. 9), por sua vez, investigou a divulgação da informação contábil sob a ótica da segunda linha de pesquisa proposta por Verrecchia (2001), ou seja, foram estudados motivos ou incentivos que levaram determinadas empresas e divulgarem suas respectivas demonstrações dos fluxos de caixa (DFC), ou seja, verificou-se se as justificativas propostas pela teoria eram válidas para explicar os motivos que levam as empresas do mercado de capitais brasileiro a divulgar as DFC voluntariamente. Segundo o autor:

\footnotetext{
Esse tipo de pesquisa é baseado no conceito de seleção adversa. A lógica desse conceito pode ser percebida quando um comprador racional interpreta a informação não divulgada como informação não favorável sobre o valor ou qualidade do ativo. Desse modo a estimativa do valor do ativo passa a ser adversa, ou seja, na falta de informação, os investidores descontam o valor de seus ativos até o momento em que se torna interessante para a firma revelar a informação, mesmo desfavorável. A noção de que determinada informação não divulgada pode ser revelada em função do comportamento dos investidores é um resultado seminal que fornece base a quase todas as pesquisas sobre esse tópico (p. 42).
}

Lima (2007, p. 15) associa essa segunda categorização à teoria das escolhas contábeis, em que os gestores, em função das imperfeições de mercado (custos de agência, assimetria da informação e externalidades), influenciam-nas. Essas imperfeições seriam derivadas da incompletude dos contratos entre os principais e os agentes e a ausência de um mercado perfeito.

Salotti (2005, p. 130) conclui em seu trabalho que as companhias abertas divulgam a DFC principalmente porque: (a) já divulgaram a DFC em período anterior; (b) dão mais importância às percepções dos seus outsiders; (c) têm melhor desempenho; (d) têm menores custos de divulgação; (e) têm maiores níveis de assimetria informacional (e, consequentemente, a divulgação provoca uma diminuição desse nível). 
Diferentemente, por sua vez, Lima (Ibid., p. 11) realizou em seu trabalho inferências sobre a divulgação baseada na eficiência, ao relacionar o comportamento do disclosure e com o custo de capital de terceiros nas empresas brasileiras de capital aberto. O trabalho concluiu que o nível de disclosure possui relação inversa com o custo de capital de terceiros.

Na opinião de Verrecchia (2001, p. 172), dos trabalhos de associação de eficiência com disclosure, tanto no contexto de bem-estar como no de eficiência para a firma, aquele com maior potencial é o que associa disclosure com redução de assimetria informacional. ${ }^{16}$

Neste sentido, Lambert, Leuz e Verrecchia (2006, p. 36) examinaram como a qualidade da informação contábil se manifesta nos custos de capital próprio, e demonstraram que ela afeta, direta e indiretamente, nas percepções sobre a distribuição futura de fluxos de caixa ${ }^{17}$.

Segundo Dantas et al. (2005, p. 73) é possível inferir que um nível maior de evidenciação contábil representa uma via de mão dupla, na medida em que ao mesmo tempo que beneficia os usuários da informação em seus processos decisórios, não obstante, existe uma relutância das organizações em aumentar o grau de transparência sob argumentos de proteção das informações de natureza estratégica, receios de questionamentos jurídicos ou mesmo custos de elaboração e divulgação das informações. As empresas procuram se limitar aos requisitos determinados pela legislação ou por normas emitidas pelos órgãos reguladores.

Também é interessante trazer à discussão os trabalhos de Daske et al. (2008 e 2013), que examinaram questões a respeito das consequências econômicas advindas de uma adoção de um padrão contábil internacional (IFRS), de forma mandatória ou voluntária, em termos de liquidez e custos de capital ao redor do mundo.

No primeiro artigo, eles identificaram que empresas que adotaram o padrão IFRS voluntariamente tiveram melhores condições de mercado (aumento de liquidez, redução no custo de capital, acréscimo no Q de Tobin) do que empresas que adotaram IFRS somente quando este

${ }^{16}$ While this essay reviews a variety of work that has attempted to link efficiency to disclosure, either in the context of social welfare or single-firm efficiency, in my opinion the one with the greatest potential is the link between disclosure and information asymmetry reduction.

${ }^{17}$ [...] we demonstrate that the quality of accounting information influences a firm's cost of capital, both directly by affecting market participants' perceptions about the distribution of future cash flows, and indirectly by affecting real decisions that alter the distribution of future cash flows. 
padrão tornava-se obrigatório ${ }^{18}$. No segundo artigo, eles classificaram as empresas em duas categorias: "Label Adopters" e "Serious Adopters", considerando o fato de elas terem realmente alterado seus padrões contábeis ou somente terem dito haver adotado, e associaram à adoção de fato, à melhora nas condições de liquidez e custo de capital, comparativamente às empresas com adoção somente rotular ${ }^{19}$. Estes artigos vêm alertar para as diferenças nos níveis de adoção de padrão contábil e suas consequências.

Esta pesquisa se propõe a estudar o fenômeno da divulgação na mesma linha investigada por Lima (2007) e Lambert, Leuz e Verrecchia (2006), mas também considera aspectos da teoria da divulgação por discricionariedade, abordado em Salotti (2005), no que se refere ao comportamento dos agentes na ausência de informações (seleção adversa).

\subsubsection{Relação de Custos versus Benefícios}

Segundo Iudícibus (2000), as convenções contábeis delimitam ou qualificam o tipo de comportamento do contador em face dos graus de liberdade que os princípios e postulados lhe permitem, ou seja, atuam como restrições (p. 67).

Nesse sentido é que ele coloca a convenção (restrição, norma) da materialidade, que pode ser enfocada sob dois ângulos, de quem faz a escrituração contábil ou audita, e do usuário da informação contábil, o qual teria muito a ver com a noção de custo versus benefício da informação contábil gerada, em que detalhes que visassem a perfeição gerariam um benefício adicional menor que o custo (mensurado também em tempo) para gerá-los (Ibid. p. 72).

Ele exemplifica essa limitação com a situação clássica de R. Anthony,

[...] sobre empregados que se utilizam diariamente de lápis em seus trabalhos de escritório; a Contabilidade poderia lançar uma partida diária do valor de tais ativos como despesas, na proporção exata da porcentagem física do material que foi consumido naquele dia. Isto poderia der considerado correto, mas absolutamente irrelevante e imaterial. Que benefícios teriam os usuários da informação deste tipo, mesmo os gerentes, se material para escritório representa uma porcentagem ínfima do ativo? (Ibid., p. 72),

${ }^{18}$ This paper examines the economic consequences of mandatory International Financial Reporting Standards (IFRS) reporting around the world. We analyze the effects on market liquidity, cost of capital, and Tobin's q [...] Comparing mandatory and voluntary adopters, we find that the capital market effects are most pronounced for firms that voluntarily switch to IFRS, both in the year when they switch and again later, when IFRS become mandatory.

19 'We classify firms into 'label' and 'serious' adopters using firm-level changes in reporting incentives, actual reporting behavior, and the external reporting environment around the switch to IAS/IFRS. We analyze whether capital market effects are different across 'serious' and 'label' adoptions. [...]. 'Serious' adoptions are associated with an increase in liquidity and a decline in cost of capital, which is not the case for 'label' adoptions". 
que é análoga à situação em que o contador de banco gasta 24 horas extras para localizar uma diferença de \$1,00 num documento contábil, na maior parte dos casos (Ibid.p. 72).

Para ele, o problema da materialidade invade toda a problemática contábil, inclusive para se estabelecer os objetivos da Contabilidade (Ibid. p. 73).

Lopes e Martins (2005) afirmam que: "Essa convenção busca relacionar o custo-benefício da produção da informação contábil, considerando sempre aspectos internos da empresa para a produção da informação em questão" e complementam em seguida que: "Essa convenção é diferenciada de acordo com o tipo de informação produzida e também em relação às características da empresa em questão" (p. 132).

Hendriksen e Van Breda (2010), também concordam que a informação deve proporcionar benefícios maiores que seus custos como uma restrição geral da contabilidade (p. 96).

Na mesma linha, o CPC (2010), na estrutura conceitual, para elaboração e apresentação das demonstrações contábeis, afirma que: “o custo de obtenção e divulgação da informação também não deve suplantar seus benefícios aos usuários” (p. 10).

No entanto, assim como Iudícibus (2006), que considera este conceito um dos mais difíceis de serem empregados em contabilidade (p. 73), Hendriksen e Van Breda (2010) entendem que essa análise de custo-benefício de informações contábeis é de extrema dificuldade, ou até mesmo, impossível de se realizar (p. 96). O próprio conselho do FASB observa “[...], mesmo que os custos e benefícios não sejam identificados além dos produtores e usuários da informação, é difícil afirmar qualquer coisa, com precisão, a respeito de sua incidência” (FASB, 1976 ${ }^{20}$, apud Hendriksen \& Van Breda, 2010, p.96).

Mas apesar da dificuldade, o FASB insiste em dizer

[...], o Conselho não conclui que deva desistir do assunto, pois há algumas coisas que pode fazer preservar a eficácia de seus padrões, em termos de custo. Antes de ser tomada uma decisão quanto ao desenvolvimento de um padrão, o Conselho precisa convencer a si mesmo de que a questão a ser regulamentada representa um problema importante e que o padrão a ser promulgado não acarretará custos a muitos e benefícios a poucos (Ibid., p.96).

\footnotetext{
${ }^{20}$ SFAC (Statement of Financial Accounting Concepts) 2, parágrafo 136.
} 
Um exemplo de custos diretos incorridos às corporações por conta de regulação contábil é dado por Iudícibus e Lopes (2004, p.250),

[...] encontrado em Bastable (1977). Ele pesquisou 18 corporações quanto ao custo incremental com Accounting Series Release (ASR) 190, que exigia que as firmas publicassem o custo de reposição. O custo direto adicional médio de atendimento dessa norma no primeiro ano para 13 firmas que responderam ao questionário foi de aproximadamente US\$ 12.400. Multiplicados pelo número de corporações sujeitas à norma (1.000), e o total anual chega a US\$ 12 milhões em 1976. E esse é o custo de apenas uma norma (mas uma das mais custosas) dentre aquelas publicadas em 1976.

Segundo Iudícibus e Lopes (2004), "Não tem havido uma completa investigação dos custos e benefícios da evidenciação estabelecida pelos pronunciamentos ao longo do tempo. [...]. Nem a SEC ${ }^{21}$ parece interessar-se com a avaliação se a regulação governamental melhora o bem-estar social.” (p. 251).

\subsection{IFRS para PMEs}

\subsubsection{De acordo com o órgão emissor de padrões contábeis internacionais}

O International Accounting Standards Committee (IASC), antes de ser substituído pelo IASB no ano 2000, em seu relatório de transição, se manifestou sobre a existência de uma demanda para uma versão especial de normas internacionais de contabilidade para pequenas empresas (IASB, 2009, p. 5) 22 .

Logo no ano de 2001, iniciou-se o projeto para desenvolvimento desses padrões, com a criação de um grupo de trabalho de especialistas para estudar o assunto. Após algumas reuniões, em junho de 2004 foi publicado o primeiro 'Discussion Paper': Visões preliminares sobre normas contábeis para pequenas e médias empresas, pelo qual foram solicitados comentários sobre a abordagem do 'Board'23 (Ibid., p. 6).

As principais questões discutidas no documento estavam relacionadas à responsabilidade do IASB em desenvolver normas, aos objetivos das normas, à destinação das normas, fundamentação das normas para PMEs nos conceitos e princípios das IFRSs completas e suas

${ }^{21}$ Securities and Exchange Commission

22 “...., the outgoing Board of the International Accounting Standards Committee said 'A demand exists for a special version of International Accounting Standards for Small Enterprises.'.”

${ }^{23}$ Conselho do IASB 
mudanças, conflitos entre as normas para PMEs e as IFRSs completas, e o formato de publicação (Ibid., p. 6).

As respostas ao 'Discussion Paper', depois de uma série de encontros para deliberações ${ }^{24}$ e uma submissão pública de questionário sobre reconhecimento e mensuração para levantar possíveis simplificações, levaram o 'Board' a publicar um 'Exposure Draft' de um padrão contábil internacional para PMEs em fevereiro de 2007, com o objetivo de oferecer uma proposta para um conjunto simplificado e autônomo de princípios, apropriados para empresas menores e não listadas em bolsa, baseados nas IFRSs completas (Ibid., p. 8).

Após uma série de respostas recebidas pelo IASB com os comentários ao 'Exposure Draft' e aplicação de um programa de teste de campo que envolveu 116 pequenas empresas de 20 países $^{25}$, foram realizadas mais 13 reuniões para deliberações, e em julho de 2009, foram publicados a Norma Internacional de Relatório Financeiro para Pequenas e Médias Empresas e seus documentos anexos ${ }^{26}$ (Ibid., p. 11).

O resultado final foi um conjunto independente de princípios contábeis baseado na versão integral dos IFRSs, porém simplificado para pequenas e médias empresas, disponível para adoção por qualquer país, independentemente de o país ter adotado as IFRSs na íntegra ou não, cabendo a cada país determinar quais entidades devem adotar o IFRS para PMEs (DELOITTE, 2010, p. 4).

Foram realizadas as seguintes simplificações: a) certos tópicos do IFRSs foram omitidos por não serem relevantes no âmbito das PMEs; b) algumas políticas contábeis contidas nas IFRSs não são permitidas, pelo fato de haver um método simplificado disponível para PMEs; c) simplificação de muitos dos princípios de reconhecimento e mensuração contidos na versão integral dos IFRSs; d) redução significativa no número de divulgações; e, e) linguagem e explicações simplificadas (Ibid., p. 20).

${ }^{24} 31$ reuniões do 'Board', desde julho de 2003 até a publicação do 'Exposure Draft'.

${ }^{25}$ Cerca de $35 \%$ delas tinham dez ou menos empregados em tempo integral. Outros $35 \%$ das empresas da amostra tinham entre 11 e 50 empregados em tempo integral. Mais da metade das empresas tinha empréstimos bancários ou saques a descoberto significativos. (IASB, 2009, p. 9).

${ }^{26}$ Basis for Conclusions on IFRS for SMEs e Illustrative Financial Statements and Presentation and Disclosure Checklist on IFRS for SMEs. 
Como resultado dessas simplificações, o IFRS para PMEs passou a ter aproximadamente $10 \%$ do tamanho da versão integral das IFRS e contém apenas cerca de $10 \%$ das divulgações exigidas pela versão integral do IFRS (Ibid., p. 20).

O documento anexo à norma, o 'Basis for Conclusion', ${ }^{27}$, procurou definir as principais questões tratadas pelo 'Board', as alternativas consideradas, e as razões para aceitar ou rejeitar algumas alternativas (IASB, 2009, p. 16), das quais foram apresentadas neste trabalho apenas as questões pertinentes ao problema de pesquisa estudado, ou seja, questões que envolvem a necessidade, o objetivo, os usuários da informação contábil e os destinatários da norma, portanto não foram tratados neste trabalho os questionamentos sobre o papel do IASB no desenvolvimento das IFRS para PMEs, as questões relativas a eventuais mudanças nas normas, formato de apresentação, opções de política contábil, entre outros discutidos no documento.

Primeiramente discutiu-se, no documento referido acima, a questão da necessidade de se estabelecer normas globais de relatórios financeiros, e argumenta-se que se elas forem aplicadas de forma consistente, elas aumentam a comparabilidade das informações financeiras e que diferenças na contabilização podem obscurecer as comparações efetuadas por diversos usuários. Como consequência da apresentação de informações financeiras comparáveis de alta qualidade, melhora-se a eficiência de alocação e precificação de capital, beneficiando aqueles que oferecem capital de terceiros ou capital próprio, assim como as empresas que buscam capital, por reduzir seus custos. Normas globais também melhoram a consistência em termos de qualidade de auditoria e facilitam a instrução e o treinamento (Ibid., p. 16).

Para o 'Board', IFRS para PMEs comparáveis entre países são necessárias pelas seguintes razões: (a) instituições financeiras concedem crédito ao exterior e na maioria das jurisdições, mais da metade das PMEs, possuem créditos bancários, e os bancos, por sua vez, se baseiam em demonstrações financeiras ao tomar decisões referentes a concessão de crédito; (b) fornecedores querem avaliar a saúde financeira dos compradores em outros países antes de vender produtos ou serviços a prazo; (c) agências de classificação de crédito tentam desenvolver classificações de modo uniforme em âmbito internacional e informações financeiras são cruciais para o processo de classificação; (d) muitas PMEs possuem fornecedores estrangeiros e utili-

${ }^{27}$ Bases para conclusão. 
zam as demonstrações financeiras de um fornecedor para avaliar as perspectivas de um relacionamento comercial de longo prazo viável; (e) empresas de capital de risco investem em PMEs de outros países; e (f) eventuais PMEs com investidores externos que não participam da gestão cotidiana da entidade (Ibid., p. 16).

Outra questão discutida no documento 'Basis for Conclusions' remete aos usuários das demonstrações financeiras de PMEs. Para o 'Board', os usuários da informação de PMEs podem ter menor interesse em certas informações contidas nas demonstrações financeiras elaboradas de acordo com as IFRS completas, do que os usuários de demonstrações financeiras de empresas abertas, e cita como exemplo, o fato de que os usuários de demonstrações financeiras de PMEs podem ter maior interesse em fluxos de caixa de curto prazo, liquidez, solidez do balanço patrimonial, cobertura de juros e tendências históricas de lucros e perdas e cobertura de juros do que em informações destinadas a auxiliar na realização de previsões sobre os fluxos de caixa de longo prazo, lucros e perdas e valor da entidade (Ibid., p. 18).

A natureza e o grau das diferenças entre as IFRS completas e uma IFRS para PMEs deveriam ser determinados com base nas necessidades dos usuários e em análises de custobenefício. Segundo o IASB (2009), na prática, os benefícios de aplicação de normas contábeis diferem entre empresas, dependendo basicamente da natureza, número e necessidades de informações dos usuários de suas demonstrações financeiras, e os respectivos custos podem não diferir significativamente (p. 18).

Portanto, de forma consistente com a Estrutura Conceitual, o 'Board' concluiu que o ponto de equilíbrio do custo-benefício deveria ser avaliado em relação às necessidades de informações dos usuários das demonstrações financeiras de uma entidade.

O documento definiu ainda quem seriam os principais grupos de usuários externos: (a) bancos que concedem crédito bancário a PMEs; (b) fornecedores que vendem a PMEs e utilizam demonstrações financeiras de PMEs para tomar decisões sobre crédito e preços; (c) agências de classificação de crédito e outros que utilizam demonstrações financeiras de PMEs para classificar PMEs; (d) clientes de PMEs que utilizam demonstrações financeiras de PMEs para decidir se irão realizar negócios; (e) acionistas de PMEs que não são ao mesmo tempo gerentes de suas PMEs (Ibid., p. 28). 
Outra questão pertinente ao trabalho está na descrição da classe de empresas às quais se destinaria as IFRS para PMEs, No julgamento do 'Board', a norma é apropriada para entidades que não têm obrigação de prestação pública de contas, as também chamadas de 'Non-publicly accountable entities (NPAE)' ou 'empresas privadas ${ }^{28}$, portanto o princípio de prestação pública de contas é o conceito que define quais são as entidades destinatárias da norma, ou seja, as empresas identificadas como “pequenas e médias", e não o seu tamanho (Ibid., p. 20).

Logo, as IFRS para PMEs não são destinadas a empresas de capital aberto e a instituições financeiras, independentemente do tamanho que essas empresas possam ter. A definição de PMEs não inclui critérios de quantificação de porte para determinar o que é uma pequena ou média empresa (Ibid., p. 25). As IFRS para PMEs destinam-se a empresas, independentemente do porte, que devam ou que escolham publicar demonstrações financeiras para fins gerais para usuários externos.

Segundo Jermakovicz e Epstein (2010), “[...] espera-se que mais de 99\% das empresas privadas de todo o mundo sejam elegíveis para usar a esse padrão ${ }^{29 "}$ (p. 73).

No entendimento do 'Board', uma entidade tem obrigação de prestação pública de contas quando seus instrumentos de dívida ou de patrimônio forem negociados em um mercado público (uma bolsa de valores nacional ou estrangeira ou um mercado de balcão, incluindo mercados locais e regionais), ou se mantiver ativos em uma capacidade fiduciária para um grupo amplo de agentes externos como um de seus principais negócios, caso de bancos, cooperativas de crédito, companhias seguradoras, corretoras/distribuidoras de títulos, fundos mútuos e bancos de investimento (IASB, 2009, p.21).

No 'Basis for Conclusions on Exposure Draft', o IASB relata que considerou como modelo de PME para elaboração do conteúdo da norma, uma entidade típica com cerca de 50 empregados, não como teste de tamanho de entidade, mas com o objetivo de identificar os tipos de transações, eventos e condições a serem observados nessas empresas, embora ele acredite que a norma sirva para empresas menores (IASB, 2007, p.19) ${ }^{30}$.

${ }^{28}$ Termo comumente utilizado em algumas jurisdições, mais especificamente na América do Norte (IASB, 2009, p. 28).

29 "Over $99 \%$ of private entities around the world are expected to be eligible to use this standard".

30 "In deciding on the content of the proposed IFRS for SMEs, the IASB focused on a typical entity with about 50 employees. The Board used the 50-employee guideline not as a quantified size test for defining SMEs 
O documento 'Basis for Conclusions', comenta ainda que existem questionamentos sobre a adequação da norma IFRS para PMEs para microempresas, em que se argumenta que muitas dessas empresas elaboram demonstrações financeiras exclusivamente para submeter às autoridades fiscais com o propósito de determinar o lucro tributável.

Em contrapartida, o 'Board' se remete ao objetivo das normas, as quais são destinadas para aplicação a demonstrações financeiras para fins gerais, ou seja, às necessidades de informações comuns de uma ampla variedade de usuários, por exemplo, acionistas, credores, empregados e o público em geral, enfim, usuários que não estejam em posição de exigir relatórios para atender suas necessidades específicas de informações sobre a posição financeira, o desempenho e os fluxos de caixa de uma entidade (IASB, 2009, p.25).

Segundo o CFC (2010), as PMEs, muitas vezes produzem demonstrações contábeis apenas para o uso de proprietários-administradores ou apenas o uso de autoridades fiscais ou autoridades governamentais. No entanto, deixa claro que demonstrações contábeis produzidas apenas para esses propósitos não são, necessariamente, demonstrações financeiras para fins gerais (p. 10).

A determinação do lucro tributável e a determinação do lucro a distribuir aos acionistas, não constituem objetivos específicos da IFRS para PMEs, assim como não tem por objetivo também, fornecer informações a proprietários-gerentes para ajudá-los a tomar decisões administrativas (IASB, 2009, p. 25).

O IASB espera realizar uma análise ampla da experiência das PMEs em aplicar o IFRS para PMEs quando dois anos de demonstrações financeiras elaboradas de acordo com essa norma tiverem sido publicadas por um número considerável de entidades. Um Grupo de Implementação foi constituído pelo IASB com a responsabilidade de encorajar países a adotar o IFRS para PMEs, garantir a implementação consistente e de alta qualidade do IFRS para PMEs em diversos países, endereçar perguntas recorrentes que inevitavelmente surgirão na adoção inicial

but, rather, to help it decide the kinds of transactions, events and conditions that should be explicitly addressed in the proposed IFRS for SMEs. The Board's goal in doing so was to make the IFRS for SMEs a stand-alone document for such typical SMEs, and also for entities smaller than 50 employees". 
da norma e identificar e solucionar problemas de falta de clareza, omissões importantes e possíveis erros no IFRS para PMEs (DELOITTE, 2009, p. 21).

Após a análise da adoção inicial, as IFRS para PMEs serão revisadas em média uma vez a cada três anos e considerará a necessidade de incluir alterações e novas IFRS que foram desenvolvidas nos últimos três anos, bem como questões específicas que tenham sido identificadas como possíveis melhorias. (Ibid., p. 21).

\subsubsection{Recepção da norma internacional 'IFRS for SMEs' pelo CFC}

Um ponto que deve ser levado em consideração para o caso brasileiro foi o fato de que os órgãos normatizadores de contabilidade do Brasil se anteciparam a diversos outros países de economia avançada na adoção das IFRS para PMEs, com a aprovação do CPC para PMEs, transformada em norma.

Ao final do ano de 2009, o Conselho Federal de Contabilidade (CFC), órgão responsável pela emissão das Normas Brasileiras de Contabilidade, aprovou pela Resolução CFC Nº. 1.255/09, a norma 'Contabilidade para Pequenas e Médias Empresas' ${ }^{31}$, derivada do Pronunciamento Técnico CPC PME Contabilidade para Pequenas e Médias Empresas, elaborado pelo Comitê de Pronunciamentos Contábeis (CPC), com base no IFRS for $\mathrm{SMEs}^{32}$ do IASB, tendo como sua vigência a partir dos exercícios iniciados em 1º de janeiro de 2010 (CFC, 2010, p. $5)$.

No entanto, todas as PMEs podem optar pelas demonstrações completas do CPC, caso contrário seguem o Pronunciamento Técnico CPC para Pequenas e Médias que se trata de um conjunto equivalente a algo como $10 \%$ do número de páginas das normas completas (Martins, Diniz \& Miranda, 2012, p. 291).

Assim, o conjunto composto por sociedades fechadas sem obrigação pública de prestação de suas contas passou, obrigatoriamente, a adotar um padrão contábil em convergência com as normas internacionais de contabilidade existentes atualmente. $\mathrm{O}$ termo PMEs utilizado na

2010

${ }^{31}$ NBC T 19.41, aprovada em 9 de dezembro de 2009 para entrada em vigor a partir de $1^{\circ}$. de janeiro de

${ }^{32}$ International Financial Reporting Standard for Small and Medium-sized Entities. 
norma não incluiu (i) companhia abertas, reguladas pela Comissão de Valores Mobiliários (CVM); (ii) as sociedades de grande porte, como definido na Lei 11.638/0733; e (iii) as sociedades reguladas pelo Banco Central do Brasil, pela Superintendência de Seguros Privados e outras sociedades cuja prática contábil é ditada pelo correspondente órgão regulador com poder legal para tanto (CFC, 2010, p. 9-11).

Há dois pontos bastante interessantes na norma que versam sobre equilíbrio entre custo e benefício, que podem ser objetos de reflexão diante de sua implantação:

2.13 Os benefícios derivados da informação devem exceder o custo de produzi-la. A avaliação dos custos e benefícios é, em essência, um processo de julgamento. Além disso, os custos não recaem necessariamente sobre aqueles usuários que usufruem dos benefícios e, frequentemente, os benefícios da informação são usufruídos por vasta gama de usuários externos.

2.14 A informação derivada das demonstrações contábeis auxilia fornecedores de capital a tomar melhores decisões, o que resulta no funcionamento mais eficiente dos mercados de capital e no menor custo de capital para a economia como um todo. Entidades, individualmente, também usufruem dos benefícios, incluindo melhor acesso aos mercados de capital, efeitos favoráveis nas relações públicas e, talvez, custos menores de capital. Os benefícios também podem incluir melhoria no processo de tomada de decisões da administração, porque a informação financeira utilizada internamente é frequentemente baseada, ao menos em parte, em informações elaboradas para os propósitos de apresentar demonstrações contábeis para fins gerais. (Ibid., p.15).

Depois de quase dois anos da recepção do padrão do IASB pelo CPC, o CFC emitiu a Resolução CFC Nº 1.418/12, que aprova um novo modelo contábil facultativo às microempresas e empresas de pequeno porte, consideradas na Lei Complementar $n^{\circ} .123 / 06^{34}$, em relação ao Pronunciamento CPC-PME.

Trata-se de um documento que contempla treze páginas de normas, cujo conteúdo é bastante sucinto e de simples entendimento. Neste documento, recomendam-se critérios contábeis mais simplificados, como por exemplo, a realização de cálculo de depreciação linear de ativos imobilizados, a avaliação dos estoques por método PEPS (primeiro que entra, primeiro que sai) sem considerar o valor justo das mercadorias, dentre outros.

${ }^{33}$ Segundo o Art. $3^{\circ}$, parágrafo único, da Lei 11.638/07 “Considera-se de grande porte, para os fins exclusivos desta Lei, a sociedade ou conjunto de sociedades sob controle comum que tiver, no exercício social anterior, ativo total superior a duzentos e quarenta milhões de reais ou receita bruta anual superior a trezentos milhões de reais" (Lei 11.638, de 28 dezembro de 2007)

${ }^{34} \mathrm{O}$ critério adotado para conceituar micro e pequena empresa para efeito de tributação, cumprimento de obrigações trabalhistas e acesso ao crédito do governo é a receita bruta anual, cujos valores são os seguintes: (i) Microempresa, receita bruta anual igual ou inferior a R\$360 mil (ii) Empresa de Pequeno Porte, receita bruta anual superior a R\$ 360 mil e igual ou inferior a $\mathrm{R} \$ 3.600$ mil. 
Vê-se, portanto, os primeiros reflexos reativos que a norma produziu, pelo menos no que se refere às microempresas e empresas de pequeno porte.

\subsubsection{Aspectos técnicos da norma CPC para PMEs}

O Manual de contabilidade societária da FIPECAFI elaborado por Iudícibus et al. (2010) apresenta a caracterização de cada tópico dos Pronunciamentos Técnicos do CPC com sua devida correspondência para o Pronunciamento Técnico PME - Contabilidade para Pequenas e Médias Empresas ao final de cada capítulo, os quais passamos a discorrer.

Primeiramente eles se remetem ao pronunciamento como um todo, dizendo que "Tratase de um documento que se salienta fortemente por sua linguagem bem mais acessível e por resumir a praticamente $10 \%$ do volume total de páginas quando comparado com os IFRS. Além do mais, contém diversas (não muitas) simplificações" (Ibid., p. 25).

Depois eles se voltam para o conceito de PME do normativo, aos quais se enquadrariam as empresas que não são obrigadas a fazer prestação pública de suas contas e que elaboram suas demonstrações, além da finalidade de gestão interna, também para finalidades gerais de usuários externos, caso dos sócios que não estão envolvidos no negócio, credores existentes e potenciais, a agências de avaliação de crédito. Inúmeras sociedades por ações brasileiras pertencem a esse universo, assim como as empresas limitadas e as que não captam junto ao público (Ibid., p. 25) e complementam:

\footnotetext{
Portanto, no Brasil as sociedades por ações fechadas (sem negociação de suas ações ou outros instrumento patrimoniais ou de dívida no mercado e que não possuam ativos em condição fiduciária perante um amplo grupo de terceiros), mesmo que obrigadas à publicação de suas demonstrações contábeis, são tidas, para fins de Pronunciamento sobre CPC, como pequenas e médias empresas, desde que não enquadradas pela Lei $n^{\circ} .11 .638 / 07$ como sociedades de grande porte. As sociedades limitadas e demais sociedades comerciais, desde que não enquadradas pela Lei 11.638/07 como sociedades de grande porte, também são tidas como pequenas e médias empresas (Ibid., p. 26).
}

O Pronunciamento Técnico CPC-PME tem a mesma estrutura conceitual para a elaboração e apresentação das demonstrações contábeis do conjunto completo dos pronunciamentos completos do CPC (Ibid., p. 48). Também tem a mesma atribuição as questões conceituais referentes aos seguintes tópicos:

- Disponibilidades (Caixa e Equivalentes de Caixa); 
- Contas a Receber;

- Estoques;

- Ativos Especiais e Despesas Antecipadas;

- Realizável a Longo Prazo (Não Circulante);

- Conceitos gerais de Passivo Exigível;

- Fornecedores; Obrigações Fiscais e Outras Obrigações;

- Impostos a Pagar;

- Provisões, Passivos Contingentes e Ativos Contingentes;

- Contratos de Construção;

- Combinações de Negócios, Fusões, Incorporações e Cisões;

- Concessões; Políticas Contábeis, Mudança de Estimativa e Retificação de Erro e Evento Subsequente;

- Demonstração do Resultado do Exercício e Demonstração Abrangente do Exercício;

- Receitas de Vendas;

- Custo dos Produtos Vendidos e dos Serviços Prestados;

- Despesas e Outros Resultados Operacionais;

- Demonstração de Fluxo de Caixa;

- Demonstração de Valor Adicionado; e

- Transações entre Partes Relacionadas.

No que se refere a Instrumentos Financeiros, em razão de a IAS $39^{35}$ ser muito trabalhosa, foram realizadas algumas simplificações: (i) foram excluídas algumas classificações como 'disponível para venda', 'mantido até o vencimento' e a opção de valor justo, os instrumentos que aderem aos critérios especificados devem ser mensurados pelo custo ou custo amortizado; (ii) utilização de um princípio mais simples de desreconhecimento de um instrumento financeiro (sem envolvimento contínuo e do pass-through); (iii) simplificação das operações de hedge (hedge accounting); e (iv) ausência de necessidade de separação de derivativos embutidos (Ibid., p. 151).

Os autores alertam que em algumas situações (raras na prática), alguns assuntos podem exigir o conhecimento dos Pronunciamentos Técnicos propriamente ditos, caso de derivativos e instrumentos financeiros complexos, mas como a maioria das empresas não trabalha com

35 International Accounting Standard 39 (CPC 38 - Instrumentos Financeiros: Reconhecimento e Mensuração) 
instrumentos financeiros que não os tradicionais (contas a receber e a pagar originadas de transações comerciais, operações financeiras de captação de recursos junto a bancos, aplicações financeiras "normais" em instituições financeiras e semelhantes), não há muito de novo para elas (Ibid., p. 26).

Segundo Martins, Diniz e Miranda (2012, p. 292), “a maioria das PMEs não possui mesmo instrumentos financeiros complexos, como derivativos, ou operações de hedge de fluxo de caixa, etc.”.

Quanto às 'Propriedades para Investimentos', caso a empresa consiga medir o valor justo sem custo e/ou esforço excessivo, utiliza-se o valor justo como base de mensuração, caso contrário, devem ser mensuradas pelo modelo custo - depreciações - desvalorizações (Iudícibus et al., 2010, p. 168). No caso de Investimentos em Coligadas, permite-se a avaliação ao valor justo, desde que a legislação assim o permita, o que não ocorre no Brasil que obriga ao uso da equivalência patrimonial (Ibid., p. 208).

No que tange a 'Efeitos nas Mudanças nas Taxas de Câmbio em Investimentos no Exterior', após o reconhecimento inicial de investimentos desse tipo, as empresas não necessitam acompanhá-las desde esse momento, para efeito de simplificação na divulgação (Ibid., p. 221).

Quanto ao tratamento do Ativo Imobilizado, o Pronunciamento impede sua reavaliação, no entanto quando da adoção inicial da norma para PMEs, à semelhança do custo atribuído (deemed cost) das demais sociedades, permite-se a adoção de um novo valor. Valor residual, vida útil e método de depreciação necessitam ser revistas somente quando há indicação de alteração relevante, ou seja, não precisam ser revistos anualmente. Ademais, em contratos de arrendamento mercantil não se exige que o arrendatário reconheça pagamentos numa base linear se os pagamentos para o arrendador são estruturados de modo a aumentar; e também não se requer a mensuração dos ativos biológicos a valor justo se o cômputo do valor demandar custo e/ou esforço excessivo (Ibid., p. 262).

Entretanto, segundo Martins, Diniz e Miranda (2012), “[...] não pode mais seguir as regras fiscais de depreciação se a vida útil e/ou o valor residual forem significativamente diferentes do ponto de vista econômico" (p. 292). 
No caso de Ativos Intangíveis, todos devem ser considerados como de vida útil finita, inclusive ágio por expectativa de rentabilidade futura (goodwill), caso a entidade de pequeno ou médio porte seja incapaz de fazer uma estimativa confiável, presume-se vida útil de 10 anos. Também não existe a possibilidade de ativação de gastos com desenvolvimento de produtos, que devem ser considerados como despesas assim que incorridos. Da mesma forma que no ativo imobilizado, valor residual, vida útil e método de amortização não necessitam de revisão anual, somente quando existir indicação relevante de alteração e não é permitida a reavaliação de ativos intangíveis. Quanto às perdas por desvalorização, a norma apresenta uma lista de eventos que indicam a existência de perdas para facilitar o cálculo e reduzir a dependência de especialistas (Iudícibus et al., 2010, p. 271).

No que se referem ao Ativo Diferido, os conceitos aplicados seguem o conjunto completo de normas, ou seja, apenas é permitida a manutenção dos saldos antigos até sua completa amortização, esse grupo não existe nas normas internacionais (Ibid., p. 277).

Quanto ao tratamento dado a 'Empréstimos e Financiamentos, Debêntures e Outros Tributos da Dívida', todos os custos de dívida devem ser reconhecidos como despesas no resultado no período em que são incorridos, ao contrário das outras sociedades, que devem capitalizar esse tipo de custo (Ibid., p. 316).

Acerca do Patrimônio Líquido, no que se refere às subvenções governamentais, não é permitido uma escolha contábil, ou seja, devem ser reconhecidas como receita quando as condições de desempenho forem atendidas e mensuradas pelo valor justo do ativo recebido ou recebível (Ibid., p. 379). Para o caso de 'Ativos Não Correntes Mantidos para a Venda' e 'Operação Descontinuada' não há necessidade de detalhamento de critérios de mensuração, no entanto, como indica desvalorização, a entidade deverá realizar um teste de recuperabilidade (Ibid., p. 404).

Existem algumas diferenças no reconhecimento e mensuração de 'Benefícios a Empregados', como: (i) ganhos e perdas atuarias devem ser reconhecidas imediatamente no resultado; (ii) os custos de serviços passados devem ser reconhecidos imediatamente no resultado, ou seja, não é permitido o diferimento no planos de benefício definido; (iii) não se exige a utilização do método de unicidade de crédito projetada caso acarrete demasiado esforço e/ou custo para a 
empresa; e (iv) não há necessidade de avaliação das premissas utilizadas para cálculo dos benefícios anualmente (Ibid., p. 537).

A única diferença em relação a 'Pagamento baseado em Ações' é que as PMEs podem utilizar o julgamento da administração na estimação do valor do pagamento, quando os preços de mercado não forem observáveis diretamente no mercado (Ibid., p. 555).

Com relação à 'Demonstração das Mutações de Patrimônio Líquido', caso a entidade opte e as únicas mudanças no PL derivarem de: resultado do período, pagamento de dividendos, correções de períodos anteriores e mudanças de políticas contábeis, essa demonstração poderá ser substituída pela demonstração de lucros e prejuízos acumulados (Ibid., p. 566).

Além do mais, o Pronunciamento CPC-PME não aborda a divulgação de Lucro por Ação (Ibid., p. 520), Correção Integral das Demonstrações Contábeis (Ibid., p. 717), Relatório de Administração (Ibid., p. 726), e Informações por Segmento, nesse último somente menciona que caso a entidade realize tal divulgação ela deverá também descrever as base de elaboração e apresentação da informação (Ibid., p. 634).

No que tange a Notas Explicativas, as exigências de divulgação são bem menores que para as demais sociedades, pois alguns tópicos não são abordados. Em alguns momentos, princípios de mensuração e reconhecimento foram simplificados e algumas divulgações não foram exigidas em consideração ao custo-benefício, como por exemplo, as informações relacionadas a mercado de capitais (Ibid., p. 628).

Os conceitos relativos a 'Consolidação das Demonstrações Contábeis e Demonstrações separadas' do conjunto completo vale para o CPC-PME com exceção à ausência de opção de consolidação proporcional para os investimento em entidades controladas conjuntamente (Ibid., p. 698)

E por fim, em relação à 'Adoção Inicial das Normas Internacionais e do CPC', não há necessidade de se apresentar as informações contábeis comparativas aos anos anteriores, quando isso for demasiadamente custoso ou demande esforço excessivo (Ibid., p. 739). 
A Deloitte (2012b) lista as principais diferenças do CPC-PME para as demonstrações completas do CPC, ressaltando que ambas foram idealizadas com base no mesmo conceito de princípios da essência sobre a forma, conforme sintetizado abaixo (p. 22).

Quadro 3 - Diferenças entre as IFRS para PME e as IFRS completas

\begin{tabular}{|c|c|c|}
\hline Tópico & CPCs/IFRSs & CPC-PME/IFRS-PME \\
\hline Número de normas & $50+$ & 1 \\
\hline Páginas & $3.000+$ & 230 \\
\hline Itens de divulgação & $3.000+$ & 300 \\
\hline Atualização & Anual & 3 em 3 anos \\
\hline Empreendimentos em Conjunto & Consolidação proporcional & Equivalência patrimonial \\
\hline Propriedade para investimento & Custo ou valor justo & Valor justo \\
\hline Planos de pensão benefício definido & Diferir ganhos e perdas atuariais & Não tem diferimento de ganhos e perdas \\
\hline Instrumentos Financeiros & 4 categorias & Simplificado \\
\hline Custos de empréstimos & Capitalizar & Não capitalizar \\
\hline Ágio/Intangível (vida útil indeterminada) & Não amortizar & Amortizar \\
\hline Custos com desenvolvimento & Capitalizar & Não capitalizar \\
\hline Revisão de vida útil e valor residual & Anual & Apenas se tiver indicativos de mudança \\
\hline
\end{tabular}

Fonte: Deloitte, 2012b, pp. 22-23

Pereira da Revista Exame PME (2011) lista uma série de efeitos mais pragmáticos das mudanças que ocorreram com relação à contabilidade baseada na legislação tributária, por exemplo:

- agora há uma nova categoria na classificação para os bens de uma pequena ou média empresa: os ativos intangíveis, bens como marcas, patentes de produtos, carteira de clientes, contratos de franquias, pontos comerciais e direitos autorais;

- empresas que recolhem impostos com base no lucro real terão de preparar dois balanços diferentes em vez de apenas um, como antes. O balanço que deve ser enviado à Receita Federal para o cálculo do imposto de renda, do PIS e da Cofins, e o balanço contábil, mais detalhado que poderá ser utilizado internamente, para registrar o patrimônio e permitir aos sócios acompanhar o crescimento da empresa;

- as notas explicativas se tornam obrigatórias também nos balanços das empresas, elas inserem informações que explicam as causas de determinados resultados e apontam tendências para os próximos anos;

- antes, para detalhar no balanço o valor de produtos mantidos no estoque, bastava tirar uma média dos preços dos itens estocados, calculava-se primeiro o preço médio dos 
produtos e multiplicava-se pela quantidade armazenada. Agora, será preciso considerar o valor atual de cada um dos produtos que estão no estoque e somá-los.

Martins, Diniz e Miranda (2012) consideram um exagero o volume de notas explicativas exigidas no âmbito das pequenas e médias empresas, estima-se que cerca de 300 (trezentos) no total (p.240).

\subsubsection{Evidências e críticas sobre aspectos das IFRS para PMEs no mundo}

Vejamos agora alguns estudos acadêmicos pesquisados no mundo referentes ao tema e algumas reações e expectativas positivas e negativas relacionadas a aspectos utilizados na norma como base para sua elaboração que podem resultar no sucesso ou fracasso de sua adoção.

O estudo de Chen et al. (2010) encontrou evidências, utilizando dados fornecidos pelo Banco Mundial, de que a qualidade das demonstrações financeiras afeta positivamente a eficiência de alocação de capital em mercados emergentes. A relação entre qualidade das demonstrações financeiras e a eficiência de alocação de capital é positiva em ambientes com prevalência de financiamento bancário na composição do capital das PMEs, e negativa em ambientes onde há incentivos para gerenciamento de resultados para fins de tributação (p. 30).

Outro trabalho semelhante, de Hope et al. (2010), também utilizando-se de dados fornecidos pelo Banco Mundial, examina o papel da transparência financeira (tomando como sua representação no teste estatístico a revisão das demonstrações financeiras por auditores externos em empresas privadas) na mitigação de restrições a acesso a capital de terceiros, e conclui: "Encontramos forte evidência que o aumento da transparência de fato reduz restrições a capta-

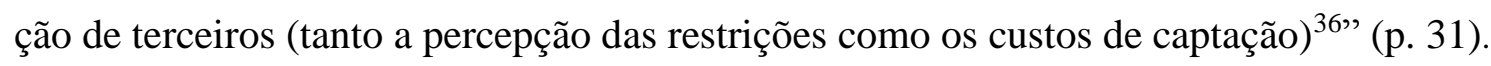

Ambos os estudos citados acima (Chen et al, 2010; Hope et al., 2010) são mencionados no discurso de Paul Pacter (2010, Webcast Part 1 Chapter 2), diretor do IASB para PMEs, como evidências encontradas de que informação com melhor qualidade produz efeito no acesso ao capital das pequenas e médias empresas, o que foi apontado como uma das razões para adoção de IFRS para PMEs.

36 "We find strong evidence that increased transparency does in fact reduce external financing constraints (both perceived constraints to financing and cost of financing)'”. 
Em outro artigo, Pacter (2009) comenta: "Usuários de PMEs estão interessados principalmente na informação sobre fluxo de caixa de curto prazo, liquidez e solvência. Eles não precisam do tipo de informação que investidores de longo prazo dos mercados de capital procuram, ou o volume de notas explicativas contidas nas IFRS completas ${ }^{37, " ~(p . ~ 29) . ~}$

Jermakovicz e Epstein (2010), em seu estudo sobre a eventualidade de adoção do padrão IFRS para PMEs nos Estados Unidos, e as diversas possibilidades de escolha de GAAP (General Accepted Accounting Principles) ${ }^{38}$, acreditam que: “[...] a implementação bem sucedida de um padrão para PMEs vai exigir a quebra da ligação tradicional entre as demonstrações financeiras e o lucro tributável, e que pode muito bem provocar uma necessidade de alteração na legislação societária [...]" 39 , ademais, pensam que "[...] No final das contas, é o mercado que vai impulsionar a demanda. O sucesso do IFRS para PMEs vai depender da extensão em que seus usuários, normatizadores e seus auditores acreditem que os padrões estão de acordo com suas necessidades" (p. 79) ${ }^{40}$.

No artigo de Seifert e Lindberg (2010), elas analisam benefícios e desafios da norma nos EUA, e atestam que, se por um lado uma organização pode se aproveitar das simplificações oferecidas pela opção de uma IFRS para PMEs, por outro, devem pensar em como será a aceitabilidade do padrão pelos fornecedores de crédito e outros stakeholders ${ }^{41}$, assim como considerar os custos de uma eventual conversão de GAAP (pp. 36-37).

Fitzpatrick e Frank (2009, pp. 53/54) também discutem a possibilidade de implantação do novo padrão nos Estados Unidos. Eles apontam no quadro abaixo as principais diferenças entre o 'US/GAAP', as 'IFRS completas' e as 'IFRS for SMEs'. Segundo eles a complexidade e o detalhamento tanto do US/GAAP como das IFRS completas, para a maioria das empresas, nem sempre são relevantes, e podem ser custosos de aplicação na prática, por outro lado 'IFRS for SMEs' são padrões completos, concisos e simplificados. No entanto, o 'IFRS for SMEs' não

37 “'Users of SMES' financial statements say they are mainly interested in information about short-term cash-flows, liquidity and solvency. They do not need the kinds of information that long term equity investors in public capital markets look for, or the volume of disclosures that full IFRS require."

${ }^{38}$ Princípios contábeis geralmente aceitos.

39 "The successful implementation of the SME Standard will require breaking the traditional bond between the financial statements and the income tax return, and may well trigger a need to amend company laws".

40 "Ultimately, the market will drive demand. The success of the IFRS for SMEs will depend on the extent to which users, preparers and their auditors believe the standards meet their needs".

${ }^{41}$ Partes interessadas. 
é bem difundido nos EUA, e por sua flexibilidade e possibilidade de uso de julgamento profissional pode fazer com que se perca a comparabilidade entre as empresas.

Quadro 4 - Similaridades e Diferenças (US/GAAP, Full IFRS, IFRS for SMEs)

\begin{tabular}{|c|c|c|c|}
\hline Padrão Contábil & U.S.GAAP & IFRS & IFRS for SMEs \\
\hline Base Fundamental & Regras & \multicolumn{2}{|c|}{ Princípios } \\
\hline Estoque em UEPS ${ }^{42}$ & Permitido & \multicolumn{2}{|c|}{ Não permitido } \\
\hline Avaliação de Estoques & Custo ou mercado & \multicolumn{2}{|c|}{ Custo ou valor realizável líquido } \\
\hline 'Goodwill' & $\begin{array}{c}\text { Não amortizado } \\
\text { Impairment de dois passos }\end{array}$ & $\begin{array}{c}\text { Não amortizado } \\
\text { Impairment de um passo }\end{array}$ & $\begin{array}{l}\text { Amortizado (até } 10 \text { anos) } \\
\text { Impairment de um passo }\end{array}$ \\
\hline 'Impairment' & Não reversível & \multicolumn{2}{|c|}{ Pode ser reversível (exceto para o goodwill) } \\
\hline Leasing & Procedimentos e testes específicos & \multicolumn{2}{|c|}{ Procedimentos similares, sem testes específicos } \\
\hline Reservas & Registradas quando prováveis & \multicolumn{2}{|c|}{ Registradas quando 'mais sim do que não' } \\
\hline Consolidação & $\begin{array}{l}\text { Considera-se a variável interesse da } \\
\text { entidade em primeiro lugar, depois } \\
\text { interesse dos votantes }\end{array}$ & \multicolumn{2}{|c|}{$\begin{array}{c}\text { Não há a variável interesse da entidade. } \\
\text { Avaliação de todos os elementos e entidades controla- } \\
\text { das consolidadas }\end{array}$} \\
\hline$P \& D^{43}$ & Geralmente, ambos são despesas & $\begin{array}{c}\text { Pesquisa: Despesa } \\
\text { Desenvolvimento: Ativo }\end{array}$ & Ambos: Despesas \\
\hline Custos de Empréstimos & \multicolumn{2}{|c|}{ Geralmente, capitalizados e amortizados } & Despesa \\
\hline Hedge Accounting & \multicolumn{2}{|c|}{ Procedimento rigoroso e específico } & Simplificado, 2 tipos \\
\hline
\end{tabular}

Fonte: Adaptado de Fitzpatrick e Frank, 2009, p. 54.

Já Herman (2010) é enfática em dizer que as condições para o uso do IFRS para PMEs não são favoráveis para o caso americano. Ela sugere que a existência de dois padrões contábeis ao mesmo tempo (Full IFRS e IFRS for SMEs) provocaria a perda de comparabilidade de balanços. Empresas do mesmo porte seriam tratadas de forma diferente simplesmente porque uma delas tem ações em bolsa e a outra não (p. 11).

Ademais haveria um grande impacto em termos educacionais em uma comunidade em franco desenvolvimento no momento, segundo ela, os estudantes de contabilidade na graduação teriam que fazer uma escolha entre uma especialização em IFRS para PMEs ou IFRS completas, com uma divisão de currículo, e, portanto, haveria duas carreiras diferentes para escolha dos estudantes, o que acarretaria em confusões e dificuldades no momento de contratação de profissionais no mercado de trabalho. Além do mais, outros usuários (bancos, gestores, reguladores, etc.) que necessitassem de comparações entre duas empresas de mesmo tamanho deveriam

\footnotetext{
${ }^{42}$ Último que entra, primeiro que sai.

${ }^{43}$ Pesquisa e Desenvolvimento.
} 
conhecer ambos os padrões contábeis. Por fim, além dos custos com treinamento de profissionais, haveria custos de conversão de padrão dentro das empresas, ou seja, seriam necessárias atualizações de sistemas, republicação de demonstrações financeiras passadas, assim como mudanças internas nas políticas contábeis, custos que ela considera redundantes (Ibid., p. 12). ${ }^{44}$

Kamnikar, Kamnikar e Burrowes (2012), afirmam que apenas um padrão para todo e qualquer tipo de empresa não funcionou e não irá funcionar nos Estados Unidos, para eles os usuários da informação precisam ser mais bem servidos de opções, eles citam os passos adiantados tomados pelo IASB e outros reguladores no mundo (Reino Unido e Nova Zelândia) para customizar os padrões contábeis às necessidades dos usuários (p. 49).

Masca e Gall (2008) tentaram identificar problemas com relação à comparabilidade e aos custos de adoção de IFRS para PMEs em pequenos negócios na Europa. Segundo os autores: “[...]. Comparabilidade é suficientemente difícil de atingir em nível nacional, muito mais em nível internacional” (p. 80) ${ }^{45}$, e ainda acrescentam: “[...]. É bem sabido que alguns países, como EUA e Reino Unido, acreditam fortemente na superioridade de seus próprios padrões contábeis.” (Zeff, 2007, citado por Masca e Gall, 2008, p.80) ${ }^{46}$.

Ademais existem outras diferenças entre países, como formas de captação, políticas fiscais, tradições regulatórias, entre outras, que também dificultam o processo (Masca \& Gall, 2008, p. 80).

Quanto aos custos, eles os apontam como o maior argumento contra a aplicação de IFRSs para PMEs pelo fato de que haveria desproporcionalidade de uma dupla contabilidade com relação às necessidades e receitas de pequenos negócios, a carga de investimentos seria

44 "The implementation of a dual standard would inhibit comparability, divide the continually developing pool of expertise, and cause growing companies needing liquidity to incur unnecessary and redundant expenses. This is why it is important that, with the rapidly approaching adoption of full IFRS, both public and private companies use the same set of standards, and why it's a mistake for the United States to adopt two levels of accounting standards".

45 "Comparability is hard enough to achieve at a national level, let alone internationally".

46 "It is well known that some countries, such as the US and even Britain, believe strongly in the superiority of their own accounting standards" 
muito pesada, especialmente em recursos informacionais e em formação profissional (Ibid., p. $81)^{47,48}$.

Em contrapartida, a percepção de custo desproporcional diminui na medida em que a empresa tem crescimento, o que segundo os autores, é o momento em que o argumento a favor pode ganhar força. No entanto, eles consideram que: “[...] não é democrático impor a uma companhia tais custos. Quem é que sabe antecipadamente que companhias irão prosperar e

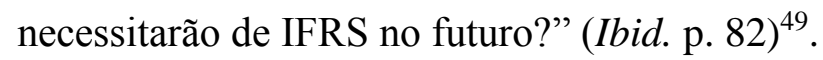

O artigo de Schiebel (2008), que examina a solidez empírica do IASB na sua minuta 'IFRS for SMEs', critica a pesquisa do 'Board' no que tange a necessidade dos usuários externos (p. 18), na sua visão:

Pesquisa para identificar as necessidades de informação de usuários externos tem geralmente focado em um grupo de usuários externos, em uma região ou país de cada vez. Não há nenhuma evidência sobre as necessidades comuns de informação de diferentes grupos de usuários externos, a nível nacional ou internacional. ${ }^{50}$

Outros fatores desfavoráveis são apontados no estudo de Bertoni e De Rosa na Europa (2010, p.9), eles consideram, por exemplo, que tendo em vista que as PMEs estão sujeitas a um controle menos rígido, logo:

[...] a introdução de contabilidade a valor justo neste contexto poderia ampliar o julgamento subjetivo dos contadores, e eventualmente, poderia levar a uma contabilidade mais criativa. Além disso, deve-se levar em consideração o risco de aumento de litígios entre proprietáriosgerentes, devido a uma reduzida verificabilidade de valores financeiros ${ }^{51}$,

também citam que alguns autores mencionam o risco de se criar uma profissão contábil com duas especialidades, aqueles qualificados para PMEs, mas não para IFRS reais (Epstein, 2007

47 "The main argument against the uniform application of IFRS for SMEs refers to the disproportionate costs involved by double accounting relative to the needs and revenues of the smaller businesses." (Haller, 2003 citado por Masca e Gall, 2008, p.81).

${ }^{48}$ [...] especially in the form of informational investments and formation on various levels (general and financial, human resources, judicial and commercial services). For SMEs the burden is that much bigger (Garbina e Burnea, 2007 citados por Masca e Gall, 2008, p.81).

${ }^{49}[. .$.$] it is not democratic to impose on the company the incurrence itself of such costs. And who can$ know in advance which companies shall prosper and need IFRS?"

50 "Research identifying the information needs of external users has generally focused on one group of external users and on one region or country at a time. There is no evidence concerning the common information needs of different external user groups at national or international levels".

${ }^{51}[. .$.$] the introduction of fair value accounting in this context could widen preparers' subjective judgment$ and, eventually, could lead to more creative accounting. Also, it should take into consideration the risk of increased litigation between owners-managers, due to a reduced verifiability of financial figures" 
citado por Bertoni e De Rosa, 2010, p.9) e o risco de se criar 'cidadãos de segunda classe' em $\mathrm{PMEs}^{52}$.

Esses autores também mencionam os problemas com aumento de custos, para eles:

[...] mudar regras contábeis implicaria em: modificar legislação comercial e tributária, as adaptando à nova estrutura de relatórios financeiros; assim como, num aumento do custo com auditoria fiscal, em função de uma maior complexidade e competências para realizar tais tarefas. A complexidade, especialmente no campo da tributação, pode ser onerosa para as PMEs, que utilizam muitas vezes um único conjunto de demonstrações financeiras para cumprir as exigências fiscais e de reporte (Bertoni e De Rosa, 2010, p. 9) ${ }^{53}$.

e quanto ao tratamento de microempresas, assim analisam

[...] não está claro como os usuários das demonstrações de entidades muito pequenas poderiam se beneficiar com isso. Outros benefícios da introdução de IFRS para PMEs podem ser mais relevantes neste caso: a possível redução do custo de capital e a remoção de vários obstáculos para a adoção do IFRS completo. Pode-se argumentar, no entanto, que os usuários das demonstrações financeiras de uma empresa de médio porte, que operam internacionalmente, têm necessidades diferentes de uma microempresa com operação no mercado local [...] (Ibid., p. 10) ${ }^{54}$,

segundo eles "[...] o projeto IASB poderia talvez revelar-se inadequado para entidades muito pequenas." (Ibid., p. 10) $)^{55}$.

Wright et al. (2012), ao discutir a necessidade de normas específicas para pequenas empresas nos Estados Unidos, são favoráveis a um GAAP de menores proporções para empresas privadas $^{56}$, eles dizem que os mais importantes usuários externos da informação nesse caso são os emprestadores, os banqueiros, além disso eles comentam que a essência do debate envolvendo a norma contempla duas características: a relevância da informação requerida e o custos do provedor da informação versus os benefícios ao usuário dela ${ }^{57}$ (p. 291).

52 [...] some authors also mention the risk of creating a two-tiered accounting profession, with some accountants qualified to deal with SMEs reporting, but not with "real" IFRS), and the fear of making SMEs "second class citizens"

${ }^{53}$ [...] Changing accounting rules would also imply modifying tax and commercial laws, adapting them to the new reporting framework8; also, the cost of tax audits would probably increase, because of the higher complexity and of the wider competencies required in such a task. The complexity that could ensue, especially in the field of taxation, could be excessively costly for SMEs, often used to fulfill reporting and tax requirements with one single set of financial statements.

${ }^{54}$ [...] it is not clear how the users of very small entities' financial statements could benefit from this. Other benefits of introducing IFRS for SMEs may be more relevant in this case: the possible lowering the cost of capital and the removal of several obstacles for the adoption of full IFRS. It could be argued, however, that the users of financial statements of a medium-sized company, operating internationally, have different needs than those of a micro-entity operating in the local market.

55 [...] Yet the IASB project could maybe reveal to be inappropriate for very small entities. de valores.

${ }^{56}$ Nos EUA o termo 'empresa privada' faz referência a empresas de capital fechado sem ações em bolsa

${ }^{57}$ [...] their most important external users are their lenders, primarily banks. [...], the essence of the debate for private entities revolves around two characteristics: relevance of information required and cost to the provider vs. benefits to the user. 
Quando discutem a existência de somente um GAAP para todo tipo e tamanho de empresa, a conclusão que eles chegam é que certos padrões requeridos são complexos, custosos, e irrelevantes aos usuários das demonstrações contábeis de empresas privadas, logo não deveriam ser exigidos ${ }^{58}$.

No Canadá também há essa discussão, chegando ao mesmo consenso de excesso de custo e irrelevância diante dos poucos usuários da informação, uma vez que essas demonstrações são preparadas somente para efeito de tributação e tomada de crédito, nesse custo ainda incluiriam a contratação de profissionais qualificados para o preparo das demonstrações, assim como educação continuada para os profissionais ${ }^{59}$ (Ibid., p. 296).

Em pesquisa realizada nos Estados Unidos quanto à percepção dos contadores americanos quanto à norma internacional para PMEs, um dos resultados encontrados foi que a possibilidade de uso de 'IFRS for SMEs' estava negativamente associada a três fatores: (a) tamanho da empresa; (b) uso de corrente de base em fluxo de caixa; e (c) uso corrente de contabilidade com base em fins tributários ${ }^{60}$ (Christie \& Brozovsky, 2010, p. 43).

Lenormand, Poulard e Touchais (2012), ao observar a proximidade da contabilidade de PMEs com aspectos fiscais, acreditam que a adoção da nova norma exigiria a supressão dos atuais laços entre a contabilidade e a legislação tributária. Essa desconexão, fonte de sobrecusto (sic), permitiria que não houvesse a todo tempo uma mistura de papéis pelo fato de se utilizar de uma contabilidade mais próxima da realidade econômica sem ser tendenciosa aos registros fiscais $^{61}$ (p. 63).

${ }^{58}[. .$.$] it has been argued that the cost of meeting all GAAP standards exceeds the benefits that users of$ private company financial statements derive. The conclusion from those desiring a change to requirements for private enterprise financial statements: certain required standards that are complex, costly, and irrelevant to users of private company financial statements and therefore should not be required.

${ }^{59}$ Their reasoning was based on the fact that private company financial statements are prepared mainly for taxation and borrowing rather than for financial markets, even those of small and medium enterprises (SMEs) that are public companies. In addition, there are very few users of financial statements of small-medium enterprises (SMEs), with only owners/managers, bankers, taxation authorities, and perhaps venture capitalists who populate the user category. [...] These costs include hiring professionals to prepare financial reports and continuing education for professionals.

60 "Likelihood of using IFRS for SMEs is negatively associated with three factors: 1) company size, 2) current use of cash basis, and 3) current use of tax basis accounting."

${ }^{61}[$ [...] L'adoption supposerait également la suppression du lien actuel entre la fiscalité et la comptabilité. Cette déconnexion, source de surcoût, permettrait toutefois d'éviter un certain mélange des rôles avec une comptabilité plus proche de la réalité économique sans être «biaisée» par des «écritures fiscales». 
Outro aspecto importante apontado, embora eles entendam que as IFRS para PMEs sejam altamente simplificadas com relação às demonstrações completas em IFRS, foi o fato de eles considerarem o novo padrão mais complexo ao compará-lo com o referencial contábil francês, principalmente por conta do conceito de valor justo, da primazia da essência sobre a forma em detrimento de uma abordagem legal, do detalhamento das notas explicativas que levantam a questão da concorrência, entre outras questões (Ibid., p. 62) ${ }^{62}$.

Bessieux-Ollier e Walliser (2012, p. 20) estudaram os determinantes da adoção voluntária de IFRS na França em empresas não listadas na bolsa, ou seja, análogas às empresas privadas nos EUA, e uma das conclusões que elas chegaram foi que o fator porte (em termos de ativos) é determinante para escolha voluntária do padrão IFRS, trazendo à tona o argumento do custo-benefício citado por Raffournier (1995), em que é menos custoso para as empresas a mudança de padrões contábeis do que para as empresas menores ${ }^{63}$.

Lo Russo (2010, p. 148) acredita que as dificuldades e o atraso na elaboração de somente um padrão internacional para PMEs, de forma simplificada, podem ser explicados pelo fato de haver uma oposição entre uma contabilidade centrada no patrimônio na Europa (critério de porte) e uma contabilidade centrada no desempenho financeiro nos Estados Unidos (critério de publicidade $)^{64}$.

O artigo de Litjens et al. (2012, p. 2) examinou as percepções de custo-benefício de preparadores das demonstrações contábeis de uma amostra de empresas holandesas potencialmente elegíveis à adoção da IFRS para PMEs ${ }^{65}$.

62 "Même si ce nouveau référentiel a été fortement simplifié, il reste toutefois plus complexe que le référentiel national français en raison notamment: du concept très critiqué de juste valeur; de la prééminence du fond sur la forme et cela au détriment de l'approche juridique; d'annexes plus détaillées, ce qui pose également le problème de la concurrence déloyale par rapport à des entreprises n'ayant pas les mêmes obligations d'information; de la prise en compte des impôts différés et de la place plus importante laissée au jugement".

63 "Size appears to be an important determinant. The bigger the firm (measured by its assets), the more likely it is to voluntarily adopt IFRS compared with smaller firms. (...). We can also advance the cost/benefit argument, as did Raffournier (1995): it is less expensive for a big company to change accounting standards than for a smaller one. From this point of view, nothing has changed between the pre-IFRS and post-IFRS periods"

64 "Les oppositions retraces ci-dessus sont bien sûr une simplification mais, ceci, explique certainement en partie les difficultés et le retard pris pour l'élaboration d'une norme international adaptée aux PME”.

${ }^{65}[. .$.$] we examined the aforementioned perceptions on costs benefits of IFRS for SMEs from a sample of$ private firms in the Netherlands that may potentially adopt IFRS for SMEs. 
Exemplos de custos associados a padrões contábeis seriam os custos de desenvolvimento e implementação (educação, processos), custo de manutenção de manutenção de conformidade, e os custos de análise da informação. Os benefícios seriam a credibilidade das demonstrações contábeis, o funcionamento do mercado de capitais, o acesso ao capital e o custo do capital, e o gerenciamento de tomada de decisões ${ }^{66}$ (FASB 1991, IASB e FASB 2008, Schipper 2010, EFRAG 2011 citados por Litjens et al., 2012, p.5).

Os resultados do estudo indicaram que as percepções dos participantes da pesquisa estão associadas com os custos e benefícios das IFRS para PMEs, no entanto as percepções quanto aos custos são mais fortes do que quanto aos benefícios, que é consistente com o fato de os custos serem mais tangíveis que os benefícios, considerados elusivos e de natureza indireta. A associação entre custo-benefício e tamanho parece capturar um efeito similar, os custos estão associados a tamanho enquanto os benefícios não ${ }^{67}$. (Litjens et al., 2012, p. 17).

\subsubsection{Evidências e críticas sobre aspectos das IFRS para PMEs no Brasil}

Dantas et al. (2010), em artigo em que se discute normas baseadas em princípios e normas baseadas em regras, embora não se explore especificamente pequenas e médias empresas, afirma-se que no caso das PMEs brasileiras:

[...] O impacto mais imediato é uma necessidade de discussão sobre a adoção de ações que supram uma parcela relevante da profissão, envolvida no atendimento a esse tipo de empresas, com o conhecimento sobre o novo modelo contábil, que exige muito mais julgamento profissional que o anterior. (p. 23).

Os estudos de Weffort (2005), que embora se concentrem na harmonização contábil na economia brasileira com um todo, e não especificamente em PMEs, comentam fatores importantes que influenciam a harmonização contábil, primeiro no que se refere ao sistema jurídico quando diz que

${ }^{66}$ [...]. Common examples of costs associated with accounting standards are the cost of developing and implementing standards (education, setting up information-gathering processes), the cost of maintaining compliance, and the cost of analyzing information. Benefits associated with accounting standards are the credibility of financial reporting, the functioning of capital markets, access to capital and cost of capital, and management decision-making.

${ }^{67}$ The results of the study indicate that preparers' perceptions are associated with costs and benefits of IFRS for SMEs, albeit preparers' cost perceptions show a stronger association with cost than benefit. It appears that a preparer's cost-benefit analysis is a non-linear process. This finding is consistent with the tangibility of preparers' costs and the more elusive or indirect nature of preparers' benefits. The association between costs and benefits and size appears to capture a similar effect since costs are associated with firm size whereas benefits are not. 
os esforços de harmonização contábil não podem ignorar que, na realidade, existe a harmonização de fato (de facto) e a de direito (de jure), não necessariamente coincidentes. A contabilidade de direito representa a consistência na forma (ou normas), e a de fato, representa a consistência na aplicação atual (ou práticas) (p. 63),

logo, a obrigatoriedade de padrões contábeis por meio de normas contaria em favor da harmonização de direito, entretanto, fatores de fraqueza na aplicação de normas ou aspectos culturais poderiam não conduzir a uma harmonização de fato, especialmente porque não são consideradas as diferenças nacionais, como os sistemas jurídicos, estágio de desenvolvimento econômico e aspectos culturais, entre outros.

Quanto à contribuição do sistema jurídico para a adoção das normas internacionais ela conclui que, o sucesso da harmonização dependerá em parte da sua capacidade de execução (enforcement) e de sua adequação aos valores culturais predominantes, inúmeros estudos indicam que há uma fragilidade dos sistemas de controle e problemas no Judiciário como morosidade, custo elevado, falta de recursos, entre outros (Ibid., p. 215).

No que se refere ao preparo do sistema educacional brasileiro, Weffort (2005) estudou três aspectos: (i) conteúdo dos cursos de graduação em Ciências Contábeis, (ii) pesquisa acadêmica (teses e dissertações dos programas de pós-graduação) e (iii) divulgação da produção acadêmica em periódicos especializados, e chegou à seguinte conclusão: “o sistema educacional profissional brasileiro não parece, atualmente, favorecer os esforços de harmonização internacional, principalmente considerando-se que, nos cursos de graduação, é pouco frequente a inserção na grade curricular da disciplina Contabilidade Internacional” (Ibid., p. 215)

Carmo et al. (2012) fizeram uma pesquisa para verificar se o ambiente jurídico dicotômico (Common Law e Code Law) influencia a opinião dos que são partes interessadas no processo contábil em relação à norma para PMEs, utilizando como referências a origem das respostas ao "Discussion Paper" do IASB (p. 244).

Os resultados encontrados demonstram que as opiniões analisadas não apresentam diferenças significativas entre os padrões de comentários dos respondentes, ou seja, o sistema jurídico do país de origem do emissor do comentário não exerceu influência significativa em relação à concordância ou discordância das opiniões do IASB expostas no "Discussion Paper", segundo os autores: 
as prováveis explicações desses resultados podem estar na pressão exercida pelo processo de globalização econômica, que tem impulsionado a troca de experiências e conhecimentos (incluindo os relacionados à legislação e à normatização contábil), na crescente necessidade das empresas de financiamento externo para suas atividades, inclusive por via do mercado de capitais e no papel exercido pela contabilidade como redutor da assimetria de informação e, consequentemente, do custo de capital das empresas (Habib, 2007; La Porta et al., 2008, citados por Carmo et al., 2012, p. 260),

o que, segundo os autores, serve de indício de que estamos caminhando para um processo de convergência de fato.

Segundo Pereira (2011), nesse novo paradigma, o profissional da área de contabilidade deverá compreender melhor as características do mercado em que o negócio está inserido, e ele ainda cita as palavras Cunha: “As novas regras devem aproximar muito os contadores das empresas para as quais eles trabalham”.

Meirelles, do jornal Valor Econômico (2012, p. 8), reporta que a adoção às mudanças caminha a passos lentos no Brasil, segundo ele, isso se deve ao fato do CFC ser um órgão regulador sem poder de fiscalização junto às empresas, e não poder aplicar multas por desenquadramento às novas normas contábeis, e consequentemente as companhias não vem procedendo os ajustes necessários. As punições somente atingiriam os contadores, em caso de comprovada má-fé ou desrespeito às normas do IFRS.

Ele ainda cita a afirmação de Fagundes, que diz que "há um descompasso entre as exigências contábeis e a Receita Federal, o que faz com que o trabalho dos escritórios tenha um custo mais elevado para as pequenas e médias empresas, que acabam por postergar os ajustes a serem feitos”, logo, hoje há a obrigação de duas escriturações distintas (Ibid., p. 9).

Continuando na reportagem, ele apresenta a opinião de Silva, que afirma que dificilmente as empresas adotam IFRS-PME por questões de governança corporativa pensando no planejamento de longo prazo, o processo ocorre quando as empresas buscam financiamentos. O que há no Brasil para ele é uma cultura de contabilidade para o Fisco (Ibid., p. 9).

Ainda se referindo às dificuldades do processo de transição à nova norma, Pontes afirma que a mudança gera ainda outros custos para as empresas que prestam serviços contábeis, que vão desde a adaptação de planos de contas e sistemas a gastos com treinamento, além de que o 
tempo gasto para preparo das demonstrações contábeis de cada cliente deve aumentar, assim como os custos adicionais. Mas sempre há de se considerar que esses custos visam benefícios futuros (citada por Girotto, 2010, p. 15).

Souza (2009, pp. 110-115) investigou a percepção dos profissionais contábeis quanto a eventuais barreiras à recepção de normas internacionais, além das já citadas necessidades de qualificação da mão de obra contábil, adaptação dos profissionais ao um sistema baseado em princípios e influência da legislação contábil, ele ainda cita os aspectos institucionais brasileiros, na medida em que o processo de regulação brasileiro, caracterizado por haver diversas instituições interferindo no processo de regulação contábil (CFC, ANEEL, entre outros), dependendo do segmento em que atuam, pode resultar em situações de conflito, uma vez que não necessariamente o mesmo conjunto de informações pode ser adequado a todas elas. Segundo ele: “os conflitos de interesses e os custos de manter vários sistemas contábeis para atender diferentes necessidades também podem criar barreiras para adoção plena das IFRS no Brasil”.

Apesar de apresentar diversas consequências teoricamente vantajosas como seus objetivos propostos, a norma internacional para PMEs ainda está distante de um consenso, visto que há uma quantidade de evidências que apontam para problemas que podem vir a ocorrer com sua adoção, não somente para as empresas e como para os usuários da informação.

Ainda é cedo para avaliar os efeitos que a norma pode produzir, mas se levarmos em consideração a atitude, isso pode nos remeter às palavras de Iudícibus e Carvalho (2001), quando dizem que: "Nas realizações mais ousadas e grandiosas de cada campo do conhecimento, nada teria sido possível se as pessoas que as imaginaram e realizaram tivessem se detido em não ferir o 'status quo'.' (p. 8).

\subsection{Considerações sobre pequenas e médias empresas brasileiras}

\subsubsection{A classificação das PMEs}

O IBGE (2003) fala que não há unanimidade sobre a delimitação do segmento das micro e pequenas empresas. O que se observa, na prática, é uma variedade de critérios para a sua 
definição tanto por parte da legislação específica, como por parte de instituições oficiais e órgãos representativos do setor, ora baseando-se no faturamento, ora no número de pessoas ocupadas, ora em ambos (p. 17).

Segundo Morais (2005) há dois indicadores básicos utilizados para definir micro, pequenas e médias empresas: (i) o número de pessoas ocupadas, utilizado, principalmente, em censos econômicos e pesquisas anuais e mensais da indústria, comércio e serviço, e (ii) receita bruta anual, utilizado, principalmente, com dois objetivos: na fixação das condições de enquadramento de micro e pequenas empresas (MPEs) em programas de tributação simplificada do governo federal e dos Estados, e em linhas de crédito para micro, pequenas e médias empresas, em bancos privados e públicos e em programas de crédito de fomento (p. 13).

No Estatuto da Micro e Pequena Empresa (Lei complementar 123/06, de 12 de dezembro de 2006), por exemplo, o critério adotado para conceituar micro e pequena empresa para efeito de tributação, cumprimento de obrigações trabalhistas e acesso ao crédito do governo é a receita bruta anual, cujos valores são os seguintes: (i) Microempresa, receita bruta anual igual ou inferior a $\mathrm{R} \$ 360$ mil (ii) Empresa de Pequeno Porte, receita bruta anual superior a $\mathrm{R} \$ 360$ mil e igual ou inferior a $\mathrm{R} \$ 3.600 \mathrm{mil}^{68}$.

O IBGE, na divulgação de suas estatísticas de empresas nacionais (2012), usa o critério de classificação usado da Organização das Nações Unidas de ocupação para definir o porte da empresa: são consideradas microempresas as empresas com até 9 pessoas ocupadas; empresas pequenas são as que possuem 10 a 49 pessoas; empresas médias, 50 a 249 pessoas; e empresas grandes, as que possuem 250 ou mais pessoas ocupadas (Schmiemann, 2008 citado por IBGE, 2012, p.32), mesmo critério usado pelo SEBRAE, Serviço Brasileiro de Apoio às Micro e Pequenas Empresas (IBGE, 2003, p.17)

Por sua vez, a Lei 11.638/07 caracteriza a empresa de grande porte para fins de divulgação de demonstrações contábeis, aquelas que não tenham ativo total superior a $R$ \$ 240.000.000,00 (duzentos e quarenta milhões de reais) ou receita bruta anual superior a $\mathrm{R} \$$ 300.000.000,00 (trezentos milhões de reais), ou seja, abaixo deste patamar a entidade pode ser caracterizada como micro, pequena ou média empresa.

${ }^{68}$ Art. $3^{\circ}$., incisos I e II da Lei Complementar 123, de 14/12/2006. 
Enfim, a utilização de conceitos heterogêneos decorre do fato de que os objetivos das instituições que promovem seu enquadramento são distintos, sejam eles por motivos de regulamentação, crédito, estudos, entre outros (IBGE, 2003, p. 17).

\subsubsection{A contextualização das PMEs no cenário brasileiro}

Em 2010, do total de empresas brasileiras, 99,7\% eram microempresas, empresas pequenas e empresas médias. Apesar do predomínio das microempresas na estrutura produtiva brasileira, as grandes empresas apresentaram as maiores participações nas variáveis analisadas de pessoal ocupado total $(35,6 \%)$, pessoal ocupado assalariado $(42,9 \%)$ e salários e outras remunerações $(58,0 \%)$, conforme informações apresentadas na tabela 1 abaixo.

Tabela 1 - Empresas, pessoal ocupado, total e assalariado, e salários e outras remunerações, segundo porte da empresa - Brasil - 2010

\begin{tabular}{|c|c|c|c|c|c|c|c|c|}
\hline \multirow{2}{*}{$\begin{array}{c}\text { Porte da } \\
\text { Empresa }\end{array}$} & \multicolumn{2}{|c|}{ Empresas } & \multicolumn{4}{|c|}{ Pessoal Ocupado } & \multicolumn{2}{c|}{$\begin{array}{c}\text { Salários e outras remune- } \\
\text { rações (1.000 R\$) }\end{array}$} \\
\cline { 2 - 9 } & Absoluto & Relativo & Absoluto & Relativo & Absoluto & Relativo & Absoluto & Relativo \\
\hline Total & 4.599 .880 & $100,0 \%$ & 37.272 .536 & $100 \%$ & 30.841 .801 & $100 \%$ & 566.598 .706 & $100 \%$ \\
\hline Micro & 4.080 .168 & $88,5 \%$ & 9.914 .335 & $26,5 \%$ & 4.497 .579 & $14,6 \%$ & 50.058 .661 & $8,8 \%$ \\
\hline Pequenas & 446.884 & $9,9 \%$ & 8.309 .365 & $22,3 \%$ & 7.433 .850 & $24,1 \%$ & 92.785 .129 & $16,4 \%$ \\
\hline Médias & 60.111 & $1,3 \%$ & 5.798 .743 & $15,6 \%$ & 5.685 .412 & $18,4 \%$ & 95.002 .272 & $16,8 \%$ \\
\hline Grandes & 12.717 & $0,3 \%$ & 13.250 .093 & $35,6 \%$ & 13.224 .960 & $42,9 \%$ & 328.452 .643 & $58,0 \%$ \\
\hline
\end{tabular}

Fonte: IBGE, Cadastro central de empresas 2010 (2012, p.32)

Conforme se observa no gráfico 1 abaixo, o pessoal ocupado no total das empresas brasileiras era composto por $82,7 \%$ de pessoal assalariado e 17,3\% de sócios e proprietários. Especificamente nas microempresas, os sócios e proprietários representavam 54,6\% do pessoal ocupado total, superando o pessoal assalariado, com $45,4 \%$ do total de pessoas ocupadas. 


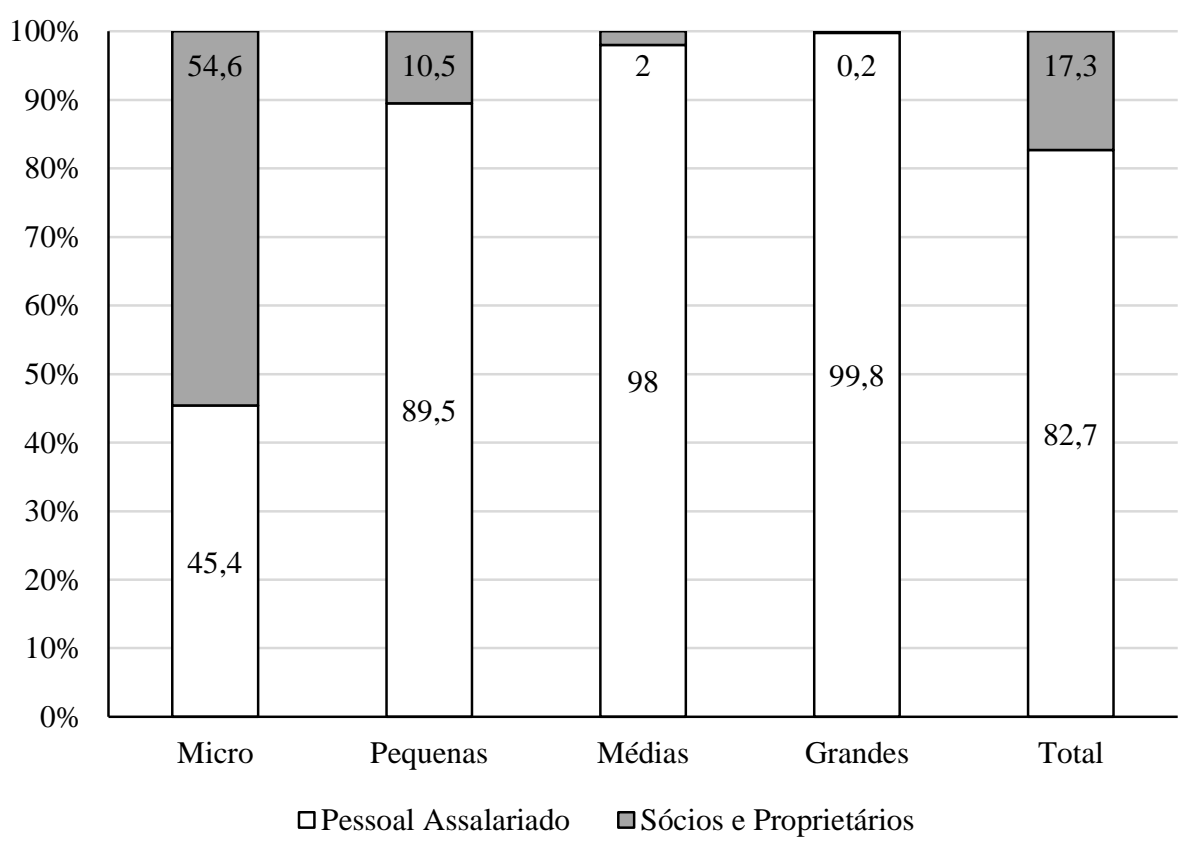

Gráfico 1 - Distribuição percentual do pessoal ocupado total, por pessoal assalariado, e sócios e proprietários, segundo o porte da empresa - Brasil - 2010

Fonte: IBGE, Cadastro central de empresas 2010 (2012, p.33)

No que se refere à estrutura de capital dessas empresas, Nobre, Câmara e Guimarães Jr. (2006, p. 7), quando investigaram o endividamento das pequenas e médias empresas no Brasil, encontraram evidências de que boa parte dessas empresas tem postura conservadora e não possui qualquer tipo de dívida (cerca de $40 \%$ ), e que há preferência pela dívida de curto prazo quando essas recorrem a capital de terceiros. Ou seja, essas empresas quando usam recursos de crédito, usam mais como fonte de capital de giro do que para investimentos de longo prazo, o que nos permite inferir que a cultura do crédito bancário como um instrumento de alavancagem de negócios no país em pequenas e médias empresas ainda é muito incipiente.

\subsubsection{Relação entre as PMEs e a contabilidade}

O artigo de Kassai (1997), que buscava relatar sua experiência junto a pesquisas realizadas em empresas de pequeno porte nos processos de tomada de decisão dos empreendedores diz que:

uma das principais dificuldades enfrentadas pelos empreendedores, na tarefa de administrar sua empresa, refere-se à compreensão dos aspectos financeiros e contábeis do negócio. Em busca de soluções procuram a assistência dos gerentes das instituições financeiras e contadores, mas nem sempre encontram o que necessitam. 
Nos autores por ela consultados, não restou dúvida sobre a importância contabilidade e utilidade do contador, no entanto há dificuldades do empreendedor entender a lógica contábil, e os relatórios financeiros caem, portanto, num mero cumprimento de obrigação legal (p. 8).

Nessa mesma linha, os estudos de Ueno e Casa Nova (2006) concluem que embora os empresários julguem a Contabilidade como importante para seus negócios, eles não possuem visão clara do que é a Contabilidade e o que se propõe esse ramo do conhecimento (p. 12).

O Banco Mundial (2005), em seu relatório de observação de padrões e códigos de contabilidade e auditoria (ROSC), apontou que a única entidade que obriga o cumprimento de padrões contábeis para companhias de pequeno e médio porte é o CFC/CRC, através do contador da empresa, ou seja, o contador como membro do conselho é obrigado a seguir o GAAP brasileiro, no entanto, como essas empresas não são obrigadas a ter um conselho fiscal, ou passar por uma auditoria estatutária, não há verificação externa das demonstrações contábeis (p. 22).

O relatório ainda cita a ausência de qualidade das demonstrações e seu relativo desuso para decisão de concessão de crédito, o que contribui para as elevadas taxas de juros para esse setor. Para este tópico o Banco Mundial reforça a necessidade de fortalecimento e extensão da capacidade de 'enforcement ${ }^{69}$ do CFC para aprimoramento de demonstrações contábeis ${ }^{70}$.

\subsection{Considerações sobre concessão de crédito pelas IFs a PMEs}

\subsubsection{Crédito e análise de crédito}

Segundo Silva (2008), crédito consiste na entrega de um valor no presente mediante promessa de pagamento no futuro. Em um banco “crédito consiste em colocar à disposição do

${ }^{69}$ Capacidade de fazer cumprir a Lei.

70 "The only enforcer of accounting standards for these companies is the CFC/CRC system, through the company's accountant. In other words, the company's accountant, as a CRC member, is required to follow Brazilian GAAP. However, since these companies are not required to undergo a statutory audit and are not required to have a 'conselho fiscal', there is no external verification of the quality of the financial statements. The ROSC team met with users of financial statements who mentioned the lack of quality of SME financial statements, and their relative disuse for credit decision, which contributes to the high spreads applied to these companies. Thus, it is essential that the CFC strengthen and extend enforcement capacity, (...), in order to promote better financial reporting by SMEs." 
cliente (tomador de recursos) certo valor sob a forma de empréstimo ou financiamento, mediante uma promessa de pagamento numa data futura". Para ele, de uma forma mais abrangente crédito pode até ser visto como parte integrante de um negócio (p. 45).

Securato (2012) elabora uma definição mais ampla, para ele "[...] em sua essência, o crédito, ou mais propriamente a operação de crédito, é uma operação de empréstimo sempre considerada como dinheiro, ou caso comercial equivalente a dinheiro, sobre o qual incide uma remuneração denominada juros, por um período previamente determinado” (p. 24).

No que se refere à função social do crédito, Silva (2008, p.50) acredita que seu uso:

(a) possibilita às empresas aumentarem seu nível de atividade; (b) estimula o consumo influenciando a demanda; (c) ajuda as pessoas a obterem moradia, bens e até alimentos; e (d) facilita a execução de projetos para os quais as empresas não disponham de recursos próprios suficientes. A tudo isso entretanto, deve-se acrescentar que o crédito pode tornar empresas ou pessoas físicas altamente endividadas, assim como pode ser forte componente de um processo inflacionário.

Segundo Schrickel (2000), o principal objetivo da análise de crédito numa instituição financeira é a identificação dos riscos nas situações de concessão de crédito, evidenciar conclusões quanto à capacidade de repagamento do tomador, e fazer recomendações relativas à melhor estruturação de crédito bancário a conceder sob a perspectiva da maximização dos resultados para a instituição (p. 25).

Yanaka e Holland (2010, p.5) segregam em cinco as classes de ativos com exposição a risco por parte das instituições financeiras conforme as definições que estão no Novo Acordo da Basileia II e no Comunicado 18.365 do Bacen: (i) Atacado (Corporate), (ii) Soberano, (iii) Bancos (Interbancário), (iv) Varejo e (v) Participações acionárias (Equity), e dentro do Atacado haveria uma subdivisão "pequenas e médias empresas".

\subsubsection{Análise de crédito à PME nas instituições financeiras}

Segundo Securato (2012), no caso das microempresas, "a análise de crédito acaba, muitas vezes, se confundindo com a dos próprios proprietários ou, ainda, com a renda por ele complementada". E adiciona que nesse momento a figura do sócio ou da família controladora é um fator importante na avaliação do risco de crédito, pois pode não haver uma clara separação entre o patrimônio dos sócios e o patrimônio da empresa (p. 197). 
Essa afirmação pode ser constatada pela lista de documentos geralmente solicitada pelas instituições financeiras, apresentada por Securato: (i) ficha cadastral simplificada, (ii) resumo de livro-caixa por meio de um quadro de entradas e saídas de recursos mês a mês referente a período recente (6 meses ou 1 ano); (iii) comprovantes de recolhimento de imposto de renda com base no lucro presumido ou outro critério de recolhimento escolhido pela empresa, documento que permitirá, por meio de análise de proporções, checar informações sobre faturamento constante na ficha cadastral. Conhecidas as alíquotas aplicáveis às empresas que optam pela tributação com base no lucro presumido, e obtendo-se o valor do imposto pago no último exercício, pode-se, pela aplicação de proporcionalidade, obter a base de cálculo do imposto, calcular o valor do faturamento, e compará-lo com o valor das vendas informado na ficha cadastral; (iv) ficha cadastral dos sócios com os comprovantes de renda, residência e outros que forem necessários, submetendo-os ao credit scoring ${ }^{71}$, conforme modelo aplicado na avaliação individual de pessoa física (Ibid., pp. 197-198).

Securato afirma ainda que os parâmetros básicos para a concessão de crédito à pessoa física ou microempresas também podem se nortear nos chamados C's do crédito: (i) Caráter (ou conceito); (ii) Capacidade de pagamento, diretamente relacionada à renda; (iii) Capital ou patrimônio pessoal do solicitante; (iv) Colateral, que diz respeito às garantias que o solicitante coloca à disposição do credor como alternativa de saída; e (v) Condições, que dizem respeito aos fatores macro ou microeconômicos que influenciam na concessão de crédito (Ibid., p. 187).

Para ele, o analista de crédito geralmente dá mais importância ao caráter e à capacidade, que representam os requisitos fundamentais para a concessão de crédito a um solicitante (Gitman citado Securato, p. 187).

Securato ainda constata que

"Os chamados bancos de varejo tendem a manter uma política mais flexível, com carteira de crédito agregando muitas operações tradicionais de valores pequenos/médios e praticando spread mais elevados. (...). O que se verifica no mercado brasileiro, entretanto, é a atuação de grandes conglomerados, com divisões internas para segmentos de mercado - atacado e varejo, enquanto a distinção entre instituições com uma ou outra característica fica com aquelas de porte menor." (Ibid., p. 284).

${ }^{71}$ Modelo de avaliação de crédito aplicável a pessoas físicas e jurídicas, onde é feita a compilação e a comparação dos dados constantes na ficha cadastral com parâmetros quantitativos e qualitativos previamente estabelecidos. Os dados são confrontados com os parâmetros a que se referem, e pontuados (Securato, 2012, p.186). 
Schrickel (2000), quando se refere a análises de crédito a empresas familiares, comenta que elas devem ser bastante criteriosas, uma vez que essas empresas são mais vulneráveis às oscilações conjunturais, e estão intimamente ligadas a desqualificação da administração e a problemática da sucessão na administração. Ao final de seu texto ele não recomenda ao banqueiro a entrar no que ele chama de "autêntico exercício de futurologia" (pp. 62-64).

Carvalho e Abramovay (2004) acreditam que as restrições de acesso ao crédito pelos tomadores de menor porte no Brasil podem ser analisadas pela ótica da seleção adversa e da assimetria de informações, assim como pela ótica da estrutura oligopolizada do setor financeiro, em que os bancos líderes conseguem organizar a concorrência de modo a evitar "guerras de preços" e ampliação indesejada da oferta em direção aos segmentos tradicionalmente excluídos de sua atividade. Nessas condições, os bancos conseguem expandir a oferta de crédito com rapidez, nos momentos de aquecimento da atividade produtiva, em especial se os juros nominais declinam, mas sem expandi-la até o ponto de incorporar a enorme demanda não atendida, localizada nas micro e pequenas empresas (p. 18).

Bedê (2004) em seu artigo sobre crédito a micro e pequenas empresas verifica que a dificuldade de acesso aos créditos bancários tradicionais é uma característica comum aos pequenos empresários. Poucas conseguem obter recursos financeiros entre as empresas recémabertas. A proporção sobe no caso das microempresas já consolidadas e é um pouco maior no grupo das pequenas. Porém, em todos os grupos, a participação de crédito bancário é pouco expressiva (p. 55).

Malhotra et al. (2007) ao exemplificar casos de relacionamento entre pequenas empresas e o setor bancário, cita o caso de sucesso do Banco Wells Fargo nos Estados Unidos, baseada na metodologia de 'credit scoring', para ilustrar como uma sofisticada infraestrutura de informação pôde aumentar o acesso ao crédito a pequenos negócios. Através de um robusto modelo que rotineiramente coletava informação de cada cliente em relação a compromissos, número de contas e ativos financeiros de origem de terceiros, a instituição cresceu até chegar a ser o maior banco americano de microcrédito em termos de volume de crédito concedido em 2004, com US\$ 6,3 bilhões, dos quais 94\% eram inseguros, sem garantias colaterais, demonstrações contábeis, comprovantes de imposto de renda, etc. ${ }^{72}$ (p. 18).

72 "Wells Fargo in the United States is an exception to the relationship-banking model pursued by the other banks profiled in this book and the majority of successful microfinance banks in the developing world. It 
Ao concluir suas inferências sobre 'credit scoring', Morais (2005) diz nas análises de risco de crédito para pequenas empresas, um escore confiável reduz drasticamente a taxa de juros cobrada no crédito bancário, estando essa condição diretamente relacionada à disponibilidade de informações confiáveis sobre a empresa pretendente ao crédito (p. 38).

Yanaka e Holland (2010, p.5) afirmam que, quanto à categorização de riscos tomados por instituições financeiras no Brasil: "Em geral, no varejo a classificação é feita através de modelos estatísticos (credit scoring, etc.) e, no atacado, através da análise julgamental”. Logo, no universo de empresas estudadas neste trabalho, podem-se encontrar instituições bancárias que usam métodos quantitativos, métodos qualitativos (análise julgamental), ou, as duas técnicas utilizadas em conjunto.

Segundo Srinivasa e Kim (1987), um modelo de análise julgamental pode ser definido por uma condução de comparações entre pares (empresas) de diversos atributos e definição de seus respectivos $\operatorname{pesos}^{73}$, geralmente estimados por dados ou por escolhas baseadas na experiência de um grupo de pessoas capacitadas ${ }^{74}$. Ou seja, as decisões de crédito no modelo julgamental possuem um conteúdo um pouco mais subjetivo em relação aos modelos baseados em credit scoring, no entanto, segundo os autores, conseguem produzir efeitos tão bem quanto os modelos estatísticos ${ }^{75}$.

Ademais, conforme estudo o BID (2002), a dificuldade de acesso ao crédito à PME decorre em função de assimetria de informações que surge da desigualdade de conhecimento

\footnotetext{
also illustrates how a sophisticated information infrastructure can increase SMEs' access to finance. Through the use a robust credit scoring model that routinely collects data on every customer on elements such as open commitments, number of accounts, and financial assets for loan origination, it has grown to be the largest SME bank in the United States in terms of total dollar volume. By 2004, via its Business Direct division dedicated to SMEs, it had a US\$6.3 billion outstanding SME loan portfolio, of which 94 percent was unsecure. (...) Total bank assets were US\$253 billion at the end of 2003. Use of the credit scoring model means that Wells Fargo accepts loan applications by mail or telephone. No collateral, financial statements or tax returns are required. Two-thirds of all decisions are made automatically based on the scorecard and the remaining one-third through 15-minute reviews. As a result, Wells Fargo's costs for processing small business loans are of US\$30 per loan are among the lowest in the industry." (p.670).

73 "[...] to conduct pairwise comparisons of a set of $n$ attributes and establish their relative weights."

74 "In general, the weights are estimated from data or from experienced decision makers or a group of experts." (p.671).

75 "The judgmental model is found to perform as well as statistical models." (p.665).
} 
sobre o uso do crédito entre o banco e o cliente, levando a que o banco não conheça as características do projeto da empresa e não detenha o controle sobre uso dos recursos pelo cliente; essa assimetria aumenta em razão de os bancos não contarem com unidades especializadas em pequenas e médias empresas ou com tecnologia de crédito apropriada para esse segmento, sendo menor a capacidade de avaliar os projetos apresentados por unidades de menor porte, se comparada à de projetos de empresas de maior porte. É frequente, ainda, a dificuldade das pequenas empresas de fornecerem as informações solicitadas pelos bancos (citado por Morais, 2005, p.32).

Segundo o estudo citado,

os maiores obstáculos ao acesso ao crédito para as PMEs em países da América Latina estão associados aos custos por provisão de perdas devido aos maiores riscos de crédito com as PMEs, em relação aos custos de emprestar a grandes empresas, e os custos associados à recuperação de garantias (Ibid., p. 33).

Além disso, conforme disseram Pinheiro e Moura (1999), no caso brasileiro, com a peculiaridade da alta sonegação fiscal e com péssimas práticas contábeis das empresas, traduz-se que apenas um banco possa conhecer o verdadeiro fluxo de caixa de determinada firma e de sua capacidade de levantar se financiar, o banco mantenedor da conta corrente da MPE (citados por Morais, 2005, p.33).

Um instrumento criado em 2008 para auxiliar a redução de risco de crédito foi o Sistema de Informações de Crédito do Banco Central (SCR), sucessor da Central de Riscos de Crédito, que possibilita a consulta de informações sobre as operações de crédito, avais e fianças prestados e limites de crédito concedidos por instituições financeiras a pessoas físicas e jurídicas no país. O Banco Central teve como objetivo municiar-se de instrumentos de avaliação dos riscos envolvidos nas operações de crédito $^{76}$.

Em 2012, foi introduzida uma nova versão do sistema, o SCR2, trazendo uma nova tecnologia, com arquitetura mais robusta e maior poder de processamento, possibilitando alterações substanciais, tais como informações detalhadas de cessões de crédito e limite para informações individualizadas, reduzidas de $\mathrm{R} \$ 5.000,00$ para $\mathrm{R} \$ 1.000,00^{77}$.

\footnotetext{
${ }^{76}$ Recuperado de http://www.bcb.gov.br/?SCROBJETIVOS, em 15 de janeiro de 2013.

${ }^{77}$ Recuperado em 15 de janeiro de 2013, de http://www.bcb.gov.br/?SCRHISTORICO.
} 


\subsubsection{Crédito bancário no Brasil}

Segundo o DIEESE (2012), o Brasil tem experimentado nos últimos anos um crescimento sustentado graças ao mercado interno, com o aumento da massa salarial e do consumo das famílias, por intermédio do mercado de trabalho e da expansão das operações de crédito bancário, respectivamente (p. 2).

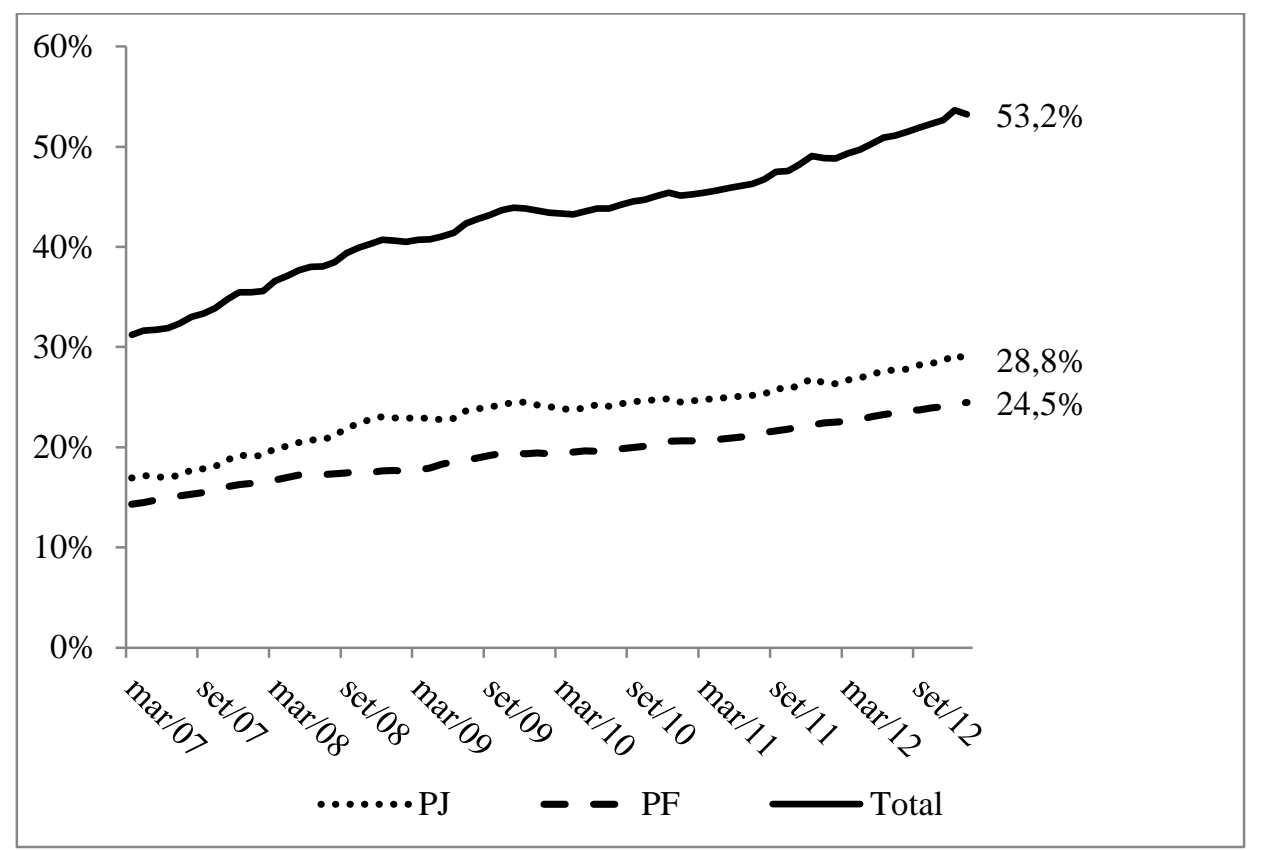

Gráfico 2 - Evolução do volume de crédito em relação ao PIB (\%) - Brasil - Mar/2007 a Jan/2013 - Pessoas Jurídicas e Pessoas Físicas

Fonte: Banco Central do Brasil ${ }^{78}$

Do gráfico 2 acima, pode-se observar que o país apresenta crescimento contínuo de volume de crédito concedido, chegando até 53,2\% do PIB, em janeiro de 2013, crescimento este que é verificado tanto para pessoas físicas como pessoas jurídicas, com relação crédito/PIB respectivamente de $24,5 \%$ e $28,8 \%$, em janeiro de 2013.

${ }^{78}$ Recuperado em 28 de fevereiro de 2013, de https://www3.bcb.gov.br/sgspub/consultarvalores/tela$\underline{\text { CvsSelecionarSeries.paint }}$ 


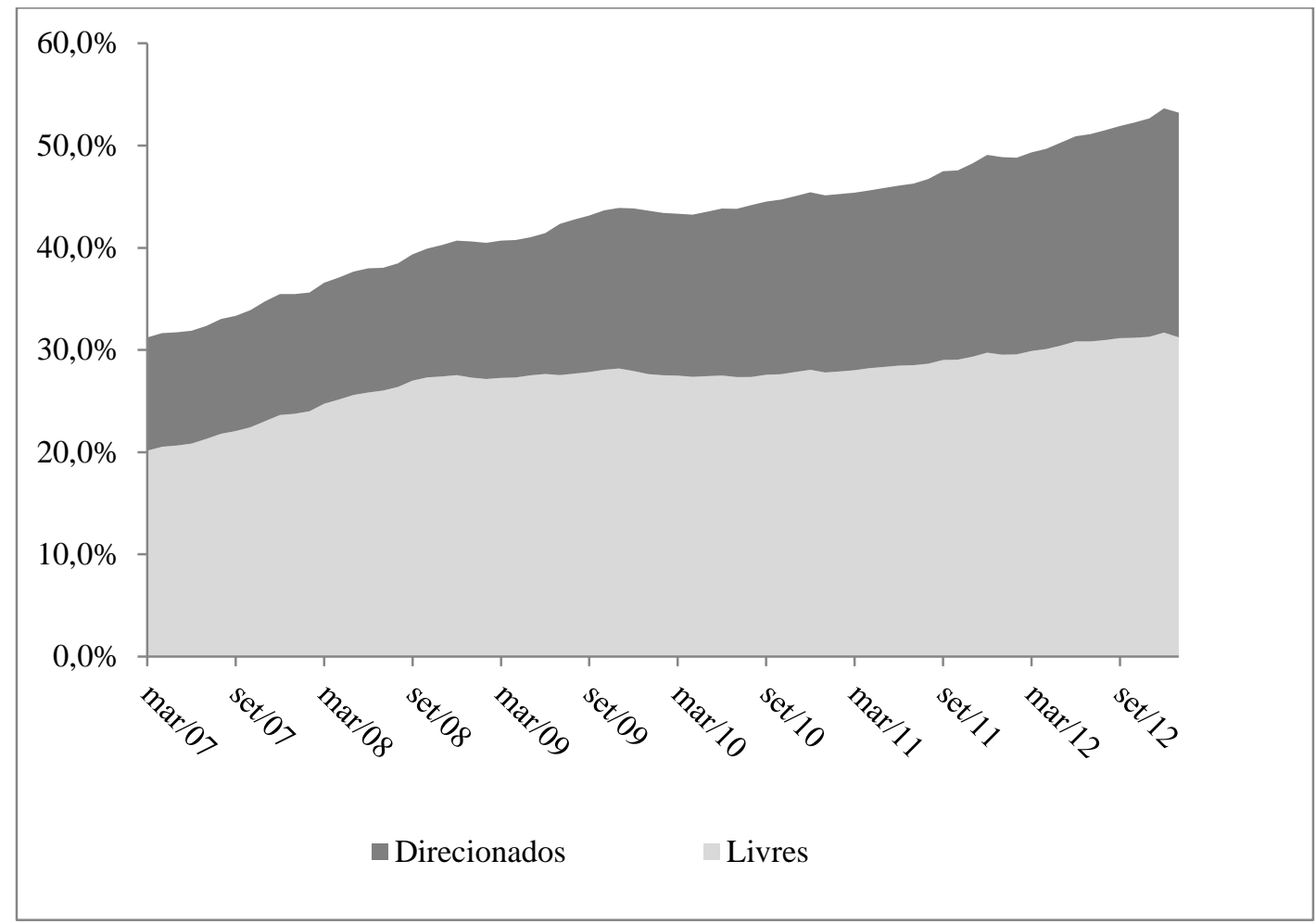

Gráfico 3 - Evolução do volume de crédito em relação ao PIB (\%) - Brasil - Mar/2007 a Jan/2013 - Tipo de Recursos (Livres e Direcionados)

Fonte: Banco Central do Brasil ${ }^{79}$

Segundo o DIEESE (2012), conforme se pode observar no gráfico 3, neste contexto de crescimento de crédito, além da expansão do crédito com recursos livres, houve a expansão das carteiras de crédito com recursos direcionados, operadas pelo BNDES, e oriundas dos créditos habitacionais incentivados pelas iniciativas de investimento do governo federal, como o Programa de Aceleração do Crescimento (PAC) e o "Minha Casa, Minha Vida” (p. 2). Em janeiro de 2013 a relação de crédito/PIB para Recursos Livres estava em 31,2\%, enquanto a de Recursos Direcionados já chegava a 22\%.

De acordo com Brito (2010, p. 89), o mercado bancário brasileiro é caracterizado por possuir uma participação relevante de operações com recursos direcionados, cujas taxas de juros e demais condições são estabelecidas em normas ou repasses do Governo, geralmente destinadas aos setores de agronegócios, habitação e infraestrutura. Em contrapartida os recursos

\footnotetext{
${ }^{79}$ Recuperado em 28 de fevereiro de 2013, de https://www3.bcb.gov.br/sgspub/consultarvalores/telaCvsSelecionarSeries.paint
} 
livres possuem taxas pactuadas livremente entre credor e tomador, tendo como funding os depósitos à vista e a prazo.

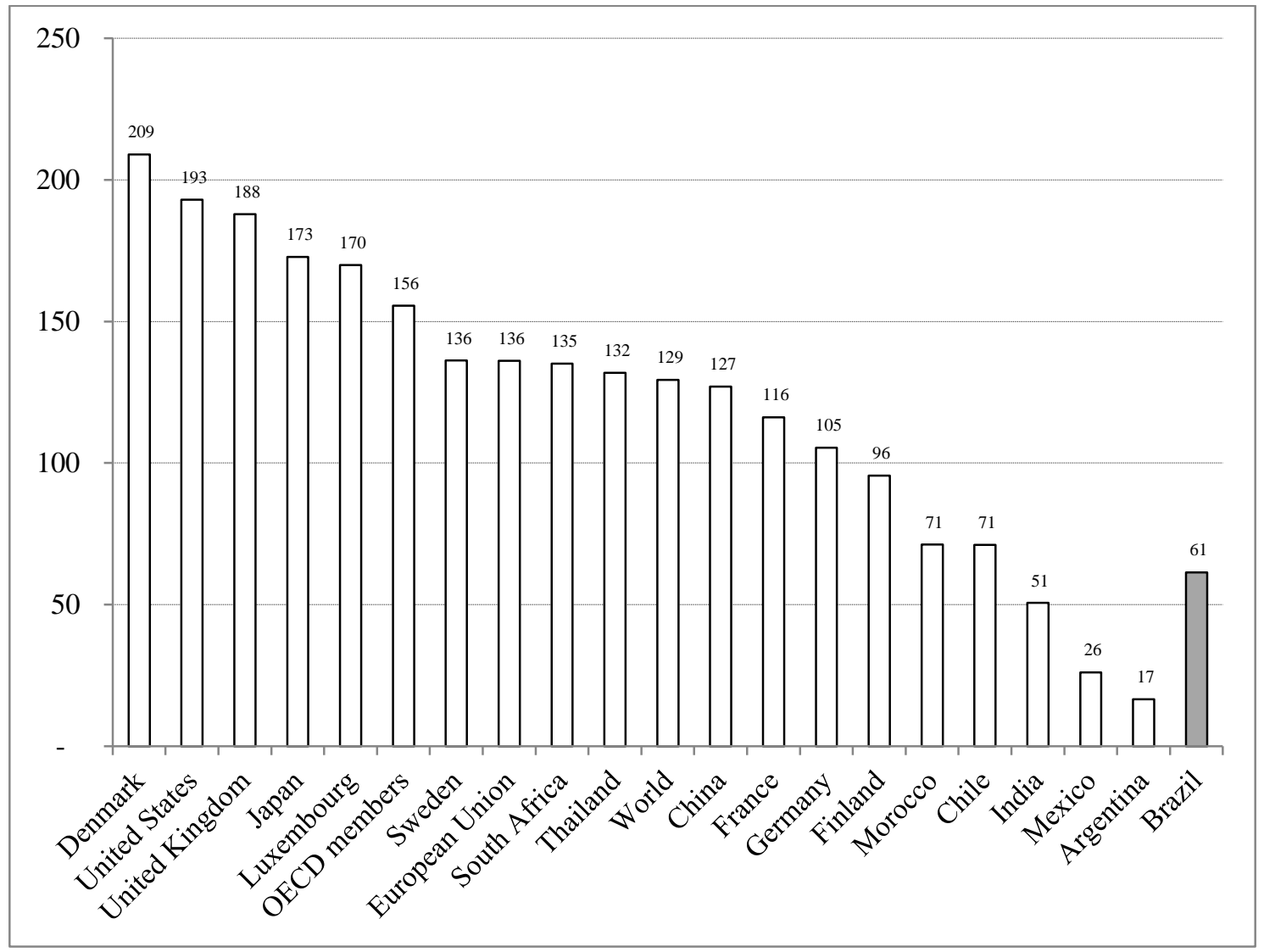

Gráfico 4 - Crédito Doméstico ao Setor Privado de países selecionados (em \% do PIB) - 2011

Fonte: The World Bank Data ${ }^{80}$

Apesar desse constante crescimento no crédito bancário, o diagnóstico feito pelo DIEESE (2012), é que relativamente a outros países desenvolvidos esse nível ainda é muito baixo, conforme pode se observar no gráfico 4 acima (p. 3), o Brasil encontra-se com apenas $61 \%$ de crédito concedido em relação ao PIB em 2011, países como Estados Unidos e Reino Unido se aproximam do nível de $200 \%$ cada um, segundo dados do Banco Mundial. Segundo dados recuperados do Banco Central do Brasil, o crédito para o setor privado ao final de 2011 estava em $47,0 \%$ do $\mathrm{PIB}^{81}$.

${ }^{80}$ Recuperado de http://data.worldbank.org/indicator/FS.AST.PRVT.GD.ZS, em 13 de novembro de 2012.

${ }^{81}$ Recuperado em 28 de fevereiro, de https://www3.bcb.gov.br/sgspub/consultarvalores/consultarValoresSeries.do?method=getPagina. 
No entanto, é importante ressaltar que esses países desenvolvidos sofrem forte influência do peso do crédito imobiliário na sua composição de endividamento, o que impacta o montante de crédito concedido a pessoas físicas e ao setor privado, diferentemente da magnitude com que ocorre no Brasil, o que não invalida a posicionamento brasileiro diante das maiores economias do mundo, mas diminui esse distanciamento. Por exemplo, ao final de 2011, os Estados Unidos mantinha cerca de $90 \%$ de crédito imobiliário em relação ao PIB $^{82}$, enquanto no Brasil esse valor se aproximava a $5 \%^{83}$.

Em contrapartida, com relação ao spread $^{84}$ bancário, o Brasil ainda está muito acima dos outros países do mundo, como por exemplo, os países da América Latina e BRICS, conforme pode-se observar no gráfico 4 abaixo (Ibid., p. 3). O spread brasileiro esteve em torno de $30 \%$, enquanto os de países como a Chile e China giravam em torno de 3\% em 2010, uma diferença gritante.

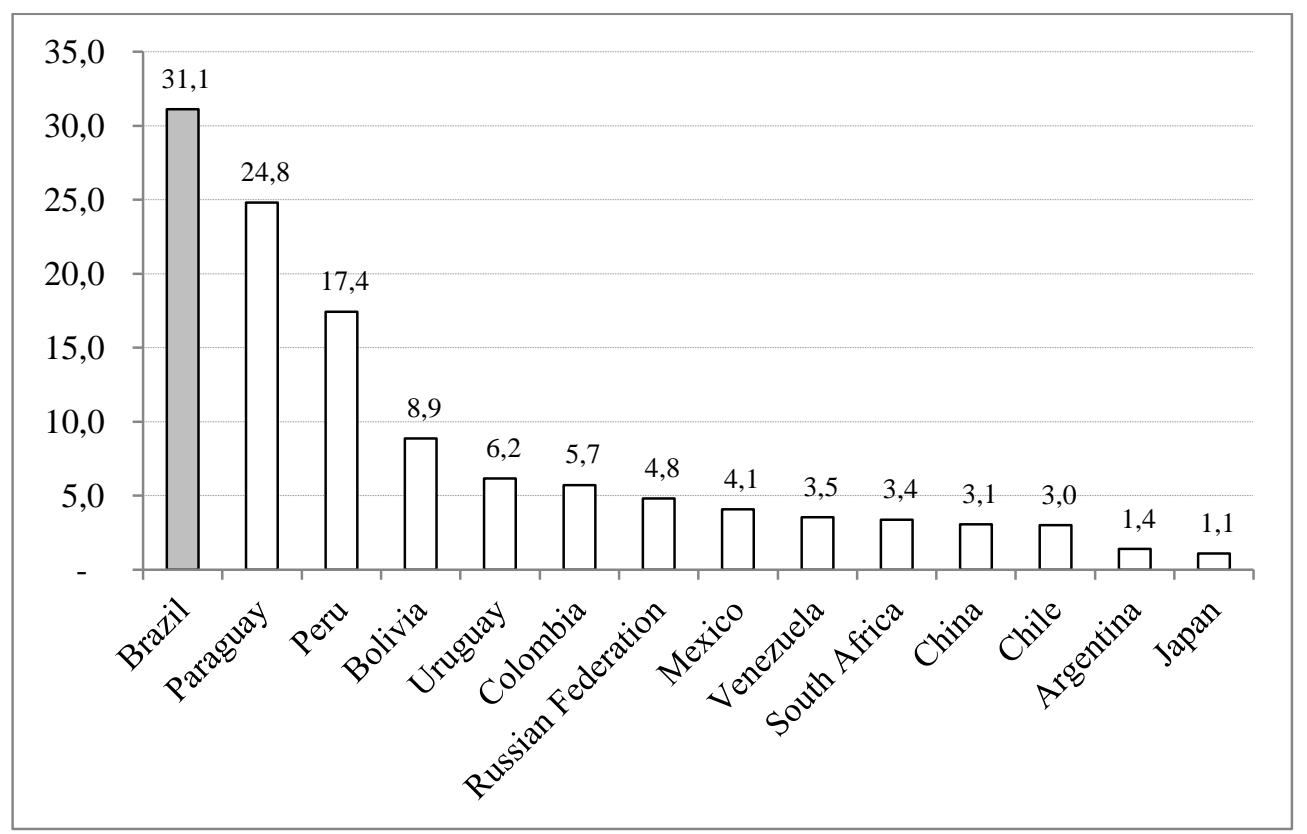

Gráfico 5 - Spread bancário no Brasil e países selecionados (Taxa de Empréstimo menos Taxa de Depósito, \%) - 2010

Fonte: The World Bank Data ${ }^{85}$

${ }^{82}$ Recuperado de http://research.stlouisfed.org/fred2/series/HDTGPDUSQ163N em 28 de fevereiro de 2013.

${ }^{83}$ Recuperado em 28 de fevereiro de 2013, de https://www3.bcb.gov.br/sgspub/consultarvalores/consultarValoresSeries.do?method=getPagina.

${ }^{84}$ Spread é um termo em inglês usado para expressar a diferença entre o que o banco paga ao aplicador para captar um recurso e quanto cobra para emprestar esse mesmo dinheiro. Em janeiro de 2012, o spread situavase em 27,8 p.p. (DIEESE, 2007, p. 8).

${ }^{85}$ Recuperado de http://data.worldbank.org/indicator/FR.INR.LNDP, em 13 de novembro de 2012. 
O DIEESE (2012) conclui seu diagnóstico sobre da composição do spread bancário brasileiro dizendo que a participação da Margem Líquida (lucro) e a Inadimplência são relevantes, havendo, portanto, espaço para a redução da participação destes componentes no spread total (p. 13).

Segundo Morais (2005), o ambiente prevalecente de baixos volumes de crédito e de altos spreads no mercado financeiro tem provocado um intenso debate nos últimos anos sobre as causas, e levado à proposição de medidas com vistas a solucionar as deficiências do mercado de crédito, como são os casos das ações voltadas ao aumento da concorrência entre os bancos e à diminuição dos custos que determinam os altos spreads (p. 26).

Além da problemática do spread bancário, o setor financeiro brasileiro é caracterizado como o mercado de baixa concorrência e com uma elevada taxa de juros básica da economia, nesse sentido o DIEESE (2012) entende que reduzir das taxas de juros bancários no Brasil é de fundamental importância como forma de aumentar os investimentos, gerar emprego e renda, e fortalecer ainda mais o mercado interno na busca por um crescimento mais sustentado para o país, sobretudo diante de um cenário de instabilidade econômica internacional (p.16).

\subsubsection{Acesso ao crédito à PME no Brasil}

Segundo levantamento realizado por Morais (2005), tomando em conta somente micro e pequenas empresas, que considerou $73 \%$ do volume de crédito concedido pelas instituições financeiras à época, a participação dos bancos estatais no crédito à MPE alcançava, em média, $40,3 \%$ dos seus créditos totais em 2003, enquanto que os bancos privados destinavam 13,6\% às empresas do segmento. A aplicação média global em MPEs era de 20,1\% em 2003 (p. 45).

Em reportagem do Jornal Valor Econômico (2012), citando estudo realizado em conjunto pela OCDE e pela CEPAL, afirmou-se que as PMEs brasileiras recebem somente $12 \%$ do crédito no país, enquanto que em países desenvolvidos esse número chega a $25 \%$, ademais, os financiamentos de longo prazo são mais caros comparados às grandes empresas, às vezes dobrando o custo de capital. 
Outra característica do crédito para o segmento é a concentração bancária, conforme se observa no ranking instituições financeiras por quantidade de crédito concedido a médias empresas, divulgado pela Revista Exame Melhores \& Maiores (2012), na tabela abaixo.

Tabela 2 - Ranking de Bancos por Crédito para Médias Empresas em 2011

\begin{tabular}{|c|c|c|}
\hline Banco & Controle Acionário & Valor (em milhões de reais) \\
\hline Itaú-Unibanco & Brasileiro & 85.680 \\
\hline Bradesco & Brasileiro & 84.047 \\
\hline Banco do Brasil & Estatal & 68.062 \\
\hline Santander & Espanhol & 47.940 \\
\hline HSBC Bank & Inglês & 17.907 \\
\hline Safra & Brasileiro & 17.073 \\
\hline Citi & Americano & 8.973 \\
\hline Banco Votorantim & Brasileiro & 8.164 \\
\hline Bicbanco & Brasileiro & 6.962 \\
\hline Banrisul & Estatal & 6.600 \\
\hline Daycoval & Brasileiro & 5.327 \\
\hline Mercantil do Brasil & Brasileiro & 3.905 \\
\hline Banco Mercedez-Benz & Alemão & 3.898 \\
\hline BNB & Estatal & 3.408 \\
\hline ABC Brasil & Bareinita & 1.905 \\
\hline
\end{tabular}

Fonte: bancos, Revista Melhores e Maiores (2012, p. 430).

Para se ter uma ideia da magnitude dos valores concedidos de crédito para empresas de menor porte, pode-se comparar, conforme dados do Banco Central, o saldo de volume total de crédito concedido no Brasil em 2011 somava 2,03 trilhões de reais (1,12 trilhões de reais para pessoas jurídicas) ${ }^{86}$, com a somatória dos créditos concedidos pelos 15 maiores bancos do setor de médias empresas, conforme tabela 2, a qual chega a quase 370 milhões de reais.

A Deloitte, juntamente com a Revista Exame PME, desde 2006, realiza anualmente um estudo com as pequenas e médias empresas com maiores índices de crescimento nos últimos anos no Brasil, no qual se investigou fatores fundamentais para suas sobrevivências.

Na pesquisa de 2009 entre os achados, verificou-se que $85 \%$ dos respondentes apontaram os juros cobrados como grande fator impeditivo de acesso ao crédito (DELOITTE, 2009, p.9), ainda com relação a recursos financeiros a pesquisa atesta que:

[...] A principal fonte de recursos utilizada pelas PMEs continua sendo o reinvestimento dos lucros, segundo declaração de $80 \%$ das PMEs que mais crescem. A utilização de recursos de

${ }^{86}$ Recuperado em 22 de março de 2013, de https://www3.bcb.gov.br/sgspub/consultarvalores/consultarValoresSeries.do?method=consultarValores 
bancos e fundos de fomento ${ }^{87}$ vem apresentando crescimento expressivo em período recente, sendo indicada por 35\% das empresas na atual edição da pesquisa [...] (Ibid., p. 18),

e complementa que:

[...] Para se ter uma ideia, o número de operações de desembolso do BNDES para as micro e pequenas empresas cresceu $88 \%$ no período entre janeiro e junho de 2009, em comparação a igual período de 2008. Para as empresas médias, a expansão foi de $8 \%$ (Ibid., p. 18).

Além da dificuldade de acesso ao crédito por conta do elevado nível dos juros como unanimidade entre os entraves citados pelas PMEs, a burocracia na concessão e as exigências de garantias são mais apontadas do que a própria disponibilidade de crédito (também citada), explicada em parte pela grande participação relativa dos bancos de fomento como provedores de recursos para PMEs (Ibid., p. 17).

Na pesquisa de 2012, 56\% dos participantes da pesquisa afirmam que garantias e exigências atualmente requeridas pelas instituições financeiras para a concessão de crédito são barreiras associadas à captação de recursos. De um lado, estão instituições financeiras que, além de precisar exigir garantias, cobram apresentação de relatórios, como o plano de negócios da empresa e os demonstrativos de gestão, e de outro, estão as PMEs, que, em alguns casos, têm dificuldades para organizar toda essa documentação e se enquadrar em todos os quesitos. Nesse ano a grande dificuldade já não era mais o padrão elevado de taxas de juros (DELOITTEa, 2012, p. 11).

O artigo de Zambaldi et al. (2011), estuda o cadastro positivo de credores e o mercado de crédito para pequenas e médias empresas no Brasil, segundo Pinheiro e Moura (2001) citados por Zambaldi et al. (2011, p. 311): “[...] Pequenos negócios geralmente pertencem ao mercado de varejo, $[\ldots]]^{\prime 88}$. Os resultados desse estudo dizem que "[...] pequenas empresas enfrentam racionamento de crédito. Além disso, os produtos de crédito com garantias parecem se encaixar ao segmento de pequenos negócios, reduzindo o risco, [...] (Ibid., 2011, p. 313) ${ }^{89}$, e para eles com a adoção do cadastro positivo

[...] instituições financeiras podem se beneficiar da disponibilidade da informação pública positiva sobre os devedores. O setor público pode encontrar neste estudo empírico evidências para apoiar a oferta do cadastro positivo sobre as PMEs e pode acelerar a concorrência entre os bancos privados. Incentivos fiscais para a formalização das PME poderiam trazer fins semelhantes.

\footnotetext{
${ }^{87}$ Banco Nacional de Desenvolvimento Econômico e Social (BNDES), Banco do Nordeste (BNB), Financiadora de Estudos e Projetos (FINEP) e outros.

88 "[...] Small businesses usually belong to the retail market, [...]"

89 “[...] small business borrowers face credit rationing. Also, liquid collateral credit products seem to fit with the small business segment, reducing risk [...]"
} 
PMEs podem encontrar evidências que níveis mais elevados de formalização se traduzem em maior acesso ao crédito [...] (Ibid., p. 314) ${ }^{90}$.

O SEBRAE realiza estudos sobre as taxas de mortalidade em micro e pequenas empresas (MPEs) e suas causas. No último deles, a entidade identificou que a respeito do capital: “[...] A origem desses recursos permanece sendo, em sua maioria, recursos próprios. Fato idêntico foi apurado na média do capital de giro, com investimentos crescentes ao longo do período, tendo como origem os recursos próprios." (SEBRAE, 2007, p. 21), ademais, observou-se que: “[...] Dentre as políticas de apoio consideradas as mais necessárias às MPE, crédito preferencial (juros e prazos) foi a mais assinalada pelos empresários [...]” (Ibid., p. 30).

Também é interessante observar os dados do índice "Doing Business" promovido pelo Banco Mundial, para o Brasil. O índice classifica 185 economias no mundo conforme seus ambientes regulatórios para operação de empresas, para isso ele aborda 10 tópicos ${ }^{91}$, que são: abertura de empresas, obtenção de licenças para construção, registro de propriedades, obtenção de crédito, proteção aos investidores, pagamento de impostos, comércio internacional, cumprimento de contratos e fechamento de empresas. No relatório de 2013, referente ao ano de 2012, o Brasil aparece na $130^{\mathrm{a}}$. colocação, confirmando a dificuldade de se empreender no país, e especificamente sobre concessão de crédito o país se encontra na $104^{\mathrm{a}}$. posição.

Conforme estudo realizado por Ferraro e Goldstein (2011), os fatores que mais influem no uso de fontes alternativas de crédito bancário para financiamento a PMEs no Brasil, assim como em outros países da América Latina, são as altas taxas de juros e a insuficiência de garantias (p. 14) $)^{92}$.

90 "[...] financial institutions may benefit from the availability of positive public information about borrowers. The public sector may find in this study empirical evidence to support the offering of positive information about SMEs. The transfer of property rights of positive information from private institutions to the market may accelerate competition among private banks. Fiscal incentives to formalization of SMEs could aim to similar purposes. Small and medium-sized firms may find evidence motivating higher levels offormalization in order to obtain greater access to credit [...]"

91 "Ease of doing business index ranks economies from 1 to 185, with first place being the best. A high ranking means that the regulatory environment is conducive to business operation. The index ranks the simple average of the country's percentile rankings on 10 topics covered in the World Bank's Doing Business. The ranking on each topic is the simple average of the percentile rankings on its component indicators".

92 "En Brasil, Bolivia, Costa Rica, Panamá, El Salvador y México, las altas tasas de interés y la insuficiencia de garantías son los factores que más influyen en el uso de fuentes alternativas al crédito bancario para el financiamiento de las pymes". 


\subsubsection{Informações contábeis e análise de crédito em instituições financeiras}

No Brasil, as instituições financeiras são obrigadas, pela Resolução 3.721 (2009) do Banco Central do Brasil, a manter uma estrutura de gerenciamento de risco de crédito que categorize suas operações sujeitas ao risco de crédito, dentre outros aspectos, conforme a situação econômico-financeira dos tomadores, assim como a estabelecer procedimentos de coleta e documentação das informações necessárias para a completa compreensão dos riscos de crédito envolvidos nas operações, com a devida manutenção atualizada das informações cadastrais das contrapartes. Logo, a partir dessa norma, acredita-se que as informações contábeis façam parte de processo de gestão de risco de crédito nas instituições financeiras.

O trabalho de Fernandes (2010) objetivou verificar o impacto da evidenciação contábil na percepção de risco do analista de crédito; ou seja,

(i) se em posse das demonstrações contábeis, perceber maior risco resulta na piora da classificação de rating da empresa, implicando em oferta de operações mais caras aos clientes assim como maior acompanhamento pelo banco e (ii) entender qual o nível de conhecimento dos analistas de crédito em contabilidade e como isso impacta o processo de avaliação de risco das empresas fechadas.

Ademais, foi investigado como os bancos credores premiavam as empresas que têm melhor grau de evidenciação contábil em relação às outras e se empresas fechadas (que não são obrigadas a divulgarem informações contábeis, mas as divulgam com boa qualidade) são mais bem avaliadas (p. 8).

Foram encontrados dados interessantes sobre os analistas de crédito em relação à contabilidade. A autora identificou que como o tempo de experiência variava muito entre os analistas atuantes no mercado bancário, era possível dividi-los em dois grupos. Através dos resultados foi possível inferir que o grupo menos experiente, demonstrou dar menos importância ao bom nível de conhecimento em contabilidade como potencializador de um melhor entendimento da situação financeira da empresa; também demonstrou ter pior nível de conhecimento em contabilidade e talvez por esse motivo também expressasse de forma mais enfática que não avalia como ótima as demonstrações contábeis enviadas pelas empresas fechadas para a análise de crédito (Ibid., p. 89), assim

[...] as duas hipóteses propostas nesta pesquisa foram confirmadas; (...). Para a hipótese 1, os resultados do cluster 2, mais experiente, evidenciam que em caso de acesso limitado ou acesso às demonstrações com baixa qualidade informacional, os analistas têm maior disposição para atribuir uma pior classificação de risco à empresa. Na hipótese 2, os resultados (...) os analistas 
do cluster 2 (mais experiente) dão mais importância do conhecimento de contabilidade e a utilização das demonstrações contábeis no entendimento da situação financeira das empresas por possuírem maior nível de conhecimento em contabilidade (correlação positiva entre tempo de experiência e acertos nas questões contábeis). (...) Quanto aos objetivos secundários propostos, na análise de cluster foi possível verificar que os analistas de crédito mais experientes (...) possuem maior disposição em premiar as empresas fechadas que têm melhor grau de evidenciação contábil em relação às outras, com atribuição de melhores ratings (...). Essa disposição aumenta de forma significativa no caso das demonstrações contábeis serem auditadas por auditores independentes, uma vez que a revisão ou auditoria das demonstrações contábeis reforça a ideia de aumento da confiabilidade e qualidade das informações prestadas no processo de crédito (Ibid., pp. 90-91).

Lopes e Martins (2005) estabelecem uma relação entre fontes de financiamento e divulgação das informações contábeis, segundo eles em países onde a maior parte do financiamento advém do mercado de capitais há maior evidenciação do que empresas de países que baseiam seu financiamento em crédito, pois os credores podem exigir informações mais detalhadas não tendo que recorrer às demonstrações financeiras publicadas. Essa relação impacta de forma direta a contabilidade, pois este é um instrumento de comunicação (p. 59).

É importante ressaltar que a análise das informações contábeis é somente um das diversas fontes de informação que influenciam nas decisões de crédito das instituições financeiras, conforme visto em Prudêncio e Salotti (2007, p. 2).

\subsubsection{Informações contábeis e acesso ao crédito às PMEs}

Segundo avaliação do Banco Mundial (2005), com relação às decisões de crédito a empresas não listadas em bolsa, incluindo as PMEs, as demonstrações financeiras tendem a não ser as mais importantes fontes de informação para a avaliação de risco de crédito, pois não contêm informação suficiente que suporte uma opinião. Os bancos, por sua vez, devem encontrar outras fontes de informação, como visitas, análise de planos estratégicos, assim como fontes secundárias (jornais, análises de terceiros, etc.) para complementar a informação das demonstrações, que conforme apontado pelos bancos, respondem apenas por um terço da classificação de crédito ${ }^{93}$ (p. 32).

93 "With regard to non-listed companies, including SMEs, there is very little trust placed in financial statements. With regard to credit decisions, for example, financial statements tend not to be a bank's most important source of information for assessing credit risk. Banks mentioned that the financial statements do not contain enough information to warrant an opinion. Instead, they must draw on other sources of information, such as site visits, analysis of a company's strategic plans, as well as information from secondary sources (newspapers, third-party analyses, etc.) to supplement the information from financial statements, which some banks mentioned only counts for about one-third of the final credit score." 
Liberatti, quanto aos impactos esperados pelo setor bancário, afirma que é preciso que os profissionais envolvidos no processo decisório de crédito estejam preparados para entender e analisar as demonstrações contábeis elaboradas no padrão internacional, a partir daí o acesso ao crédito poderá melhorar, pois o processo de concessão ocorrerá de modo mais confiável, resultando em uma possível diminuição de 'impairment' dessas operações no setor bancário brasileiro (citado por Girotto, 2010, p. 13).

Acredita-se na redução de assimetria de informações nas gestões de crédito para PME’s com a adoção de um padrão contábil uníssono. Neste sentido, tanto os preparadores de demonstrações como os analistas delas deverão estar preparados para uma nova linguagem contábil. Logo, tanto empresas de pequeno e médio porte, por meio de seus contadores, como instituições financeiras, por meio dos analistas de crédito dessas empresas, deverão ser treinados e instruídos sobre o novo padrão contábil.

O artigo de Pacter (2008) trata de uma série de vantagens em se adotar o padrão 'IFRS for SMEs'. No que se refere a relações com instituições financeiras, ele afirma que o setor bancário geralmente concede crédito além dos limites de seus países de origem, e que na maioria das jurisdições, mais da metade das empresas privadas, têm créditos de bancos, logo, banqueiros necessitam de demonstrações financeiras confiáveis para tomar decisões quanto a concessão de créditos, e poder estabelecer termos e taxas, além de monitorar seus crédito concedi$\operatorname{dos}^{94}$. Ele faz a mesma referência a agências de rating, investidores de outros países, entre outros (p. 5).

Em seu artigo escrito no ano anterior, Pacter (2007, p.16) diz que: “os bancos querem a informação que eles entendem e comparam ${ }^{95}$ ” e complementa que: “[...] Diferenças contábeis reduzem entendimentos, obscurecem comparações e conduzem para decisões imperfeitas. ${ }^{96}$ ",

94 "Financial institutions make loans to private entities, often across borders. In most jurisdictions, over half of all private entities, including the very small ones, have bank loans. Bankers rely on financial statements in making lending decisions, in establishing terms and interest rates and in monitoring loans"

95 "Banks want the data they can understand and compare." sions."

96 "Accounting differences reduce understandability, obscure comparisons and lead to sub-optimal deci- 
Conforme pesquisa realizada no Reino Unido sobre as necessidades dos usuários de informações contábeis, os resultados apontaram para os bancos como os mais importantes usuários das demonstrações financeiras para pequenas e médias empresas ${ }^{97}$ (Sian \& Roberts, 2009, p. 302).

A dissertação de Ross (2000) verificou que micro e pequenos empresários têm dificuldades de relacionamento com os bancos em diversos aspectos (relacionamento com a gerência, atendimento informatizado), tendo em vista primeiramente à falta de recursos, assim como à falta de habilidade de gerir seus recursos (aplicar e tomar dinheiro) (p. 150).

Kassai e Kassai (2001) apontam como principais causas para a dificuldade de se "levantar dinheiro" junto a instituições financeiras pelas micro e pequenas empresas, as elevadas taxas de juros da economia brasileira e a inexistência de uma contabilidade estruturada, capaz de gerar informações que facilitem o processo de captação financeira, assim como, minimizem o custo de capital, pois este é diretamente proporcional ao risco identificado nas análises (p. 2).

Continuando nessa mesma temática, Kassai e Casa Nova (2006) dizem que em um ambiente de empresas de pequeno porte: "a habilidade e os conhecimentos em finanças das pessoas envolvidas são limitados, e os recursos disponíveis ainda mais escassos, tornando mais desgastante a relação entre o dono da empresa e o gerente do banco" (p. 3).

No que se refere às informações contábeis, os autores atestam que

\begin{abstract}
De um lado, a pequena empresa não dispõe de uma contabilidade confiável e, de outro, o gerente tem seu grau de autonomia em relação à liberação do empréstimo muito reduzido. Devido a isso, ambos passam a levantar e a "produzir" informações na tentativa de convencer o sistema bancário a liberar o empréstimo. Esse sistema chega, muitas vezes, a ser tão rigoroso que para o empréstimo ser liberado a empresa tem que demonstrar que não precisa dele (Ibid., p. 6).
\end{abstract}

Também se referindo às informações contábeis, mas se restringindo a MPEs, Morais (2005) entende que o pequeno empenho das empresas e dos seus contadores em manter práticas contábeis corretas, permitindo maior controle e transparência e, consequentemente, a disponibilização de informações mais completas e confiáveis, seria decorrência dos mecanismos de 
simplificação da arrecadação tributária federal para as pequenas e médias empresas, que as desobrigam da apresentação de demonstrativos completos ao Fisco (p. 39).

Morais (2005), ao concluir seu trabalho sobre as condições de acesso das pequenas empresas ao crédito, mostra que a disponibilidade de informações nos processos de análise e aprovação de crédito pelos bancos é importante. Os dados sobre a situação econômica e financeira, os registros contábeis, as informações relativas aos compromissos nas relações comerciais e no mercado financeiro, entre diversas outras, ajudam a definir o perfil de risco da empresa e a avaliação da capacidade de pagamento dos créditos solicitados (pp. 55-56).

Sua pesquisa procurou avaliar até que ponto o aspecto das assimetrias de informações dificultavam e criavam barreiras de acesso ao crédito nas MPEs. Esses fatores foram classificados em três grupos: (a) os decorrentes de inadequada condução gerencial, que resultam em práticas contábeis e baixa qualidade em geral das informações disponíveis; (b) os decorrentes das altas taxas de mortalidade e alta informalidade; e (c) questões regulatórias, sendo a principal a insegurança jurídica nos créditos concedidos a MPEs, em decorrência das deficiências dos processos judiciais de cobrança de créditos em atraso (Morais, 2005, p.56), e assim finaliza:

Os problemas relatados permitem concluir que um extenso número de empresas continuará fora do mercado de crédito, incapazes que estão de apresentar as informações requeridas pelos bancos sobre sua situação legal e tributária, e demonstrativos contábeis que espelhem com maior realidade sua situação econômico-financeira e dados reais sobre suas receitas operacionais, em face das práticas de sonegação fiscal (Ibid., p. 57).

Ademais, para ele, a adoção de práticas contábeis racionais pode conduzir à ampliação da bancarização (sic) de pequenas empresas e à melhoria importante do acesso ao crédito, superando uma forte barreira presente no relacionamento bancário, que vem contribuindo para a assimetria de informações no mercado de crédito às MPEs (Ibid., p. 58).

Prudêncio e Salotti (2007, p. 3) estudaram a importância dos dados contábeis de micro e pequenas empresas para o processo decisório em crédito, e verificaram que:

esses dados podem ser úteis para a determinação do risco de crédito, ou seja, as pequenas e micro empresas, podem também como as grandes, possuir considerável índice de previsão de risco de crédito com demonstrações contábeis, ou então que os dados coletados das informações contábeis possam contribuir com peso relevante para a formulação de um modelo ou solução para auxiliar o processo de análise e concessão de crédito. 
Eles concluíram que a contabilidade fornece apenas uma pequena contribuição na determinação do risco de crédito das micro e pequenas empresas, pois mais de $90 \%$ deste risco pode ser explicado por outras variáveis que não são contábeis e que fazem parte dos outros C's de crédito (Ibid., p. 12).

Eles ainda acrescentaram ainda que:

\begin{abstract}
o resultado encontrado pode ser consequência de fatores como a elaboração das demonstrações contábeis por um escritório externo a empresa; a elaboração de demonstrações contábeis apenas para efeito fiscal, sem a efetiva qualidade necessária; devido ao desconhecimento por parte dos proprietários dos benefícios da escrituração contábil e da elaboração de demonstrações contábeis para a gestão dos negócios. Outro fator importante é que essas demonstrações não são submetidas ao processo de auditoria externa. (Ibid., p. 13)
\end{abstract}

Malhotra et al. (2007), no artigo que trata da expansão do acesso ao crédito, afirmam que pequenas e médias empresas identificam a ausência de acesso a serviços financeiros como uma restrição chave para crescimento e investimento, como consequência dos seguintes fatores: (a) distorções das políticas do setor financeiro; (b) falta de conhecimento por parte dos bancos; (c) assimetria de informação, i.e. ausência de demonstrações contábeis auditadas; e (d) altos riscos associados a créditos bancários a $\operatorname{PMEs}^{98}$ (p. 6).

Para exemplificar as distorções de políticas existentes setor financeiro, eles citam: (i) as taxas de juros altas como desencorajadoras a créditos com riscos maiores, um exemplo de sucesso na contramão foi o caso do Bank Rayat Indonesia (BRI) em 1983, que diante do controle das taxas de juros experimentou novos produtos para micro e pequenos empreendedores e passou de um conhecido produtor de prejuízos a instituição rentável; (ii) tomada de crédito dos bancos pelas empresas estatais, caso da China, e pelos governos, com ativos do governo sempre mais seguros, que acabem por afastar o crédito do setor privado; (iii) créditos diretos do governo, que na maioria das vezes machucam ao invés de ajudar, que distorcem as forças de mercado, são arriscadas, acabam em prejuízos e retardam o desenvolvimento do mercado financeiro; (iv) ambiente institucional legal e regulatório que não suporta diferentes formas de financiamento; e (v) ausência de direitos de propriedade (Ibid., pp. 6-9)

98 "Small firms identify lack of access to financial services as one of the key constraints to growth and investment. SMEs are usually more credit constrained than other segments of economy because if the following: (a) financial sector policy distortions; (b) lack of know-how on the part of banks; (c) information asymmetries, for example, lack of audited financial statements; and (d) high risks inherent in lending to SMEs." 
No que se refere à falta de conhecimento especializado ${ }^{99}$ dos bancos sobre PMEs, os autores dizem que comparativamente a empresas grandes, os custos de transação associados aos processos e acompanhamentos de crédito bancário a PMEs, embora fixos, são ineficientes na visão os bancos. Faltam a eles técnicas como 'credit scoring' para aumentar volume e diminuir custos ${ }^{100}$. Vale dizer que o exemplo não se verifica para caso das instituições financeiras no Brasil.

Quanto à assimetria informacional, os pesquisadores afirmaram que ela restringe o crédito a PMEs na medida em que os custos de obtenção de informações sobre essas empresas são altos, nesse sentido os riscos de se emprestar também são maiores e o banqueiro tende a cobrar preços altos de juros ou mesmo desistir de conceder o crédito ${ }^{101}$, além do mais, PMEs não são obrigadas a adotar padrões internacionais de contabilidade, dificultando ainda mais o trabalho dos auditores dessas informações, o que pode acarretar em ainda mais custo nos créditos bancários $^{102}$.

O último fator determinante à restrição ao crédito para PMEs está ligado à vulnerabilidade e taxa de mortalidade desse tipo de empresa, a volatilidade desse tipo de empreendimento é comum em todo o mundo. Ademais, Malhotra et al. (2007) concluem que a administração dessas empresas é caracterizada pela fragilidade de qualificação de suas pessoas e processos (p. 12).

Por outro lado, a pesquisa de Souza et al. (2006), realizada tomando-se uma amostra de instituições financeiras situadas na cidade de Belo Horizonte, apesar de não possibilitar generalizações, conclui apontando indícios de que as demonstrações contábeis são realmente utilizadas no processo de concessão de crédito a pequenas e médias empresas e que as dificuldades de acesso ao crédito por elas enfrentadas podem ser minimizadas com a apresentação de um conjunto de informações econômicas, financeiras e patrimoniais consistentes (p. 13).

99 “Know-how"

100 "SMEs typically require relatively small loans compared with large firms. The transactions, costs associated with processing and administrating loans are, however, fixed, and banks often find that processing small SME loans is inefficient. They lack the techniques, such as credit scoring, to increase volume and lower costs. "'(Ibid., p.10)

101 "[...] for banks to obtain information on the creditworthiness of potential SME clients is difficult or costly. If, as a result, lenders perceive the risks of lending to SMEs to be greater than they actually are, they will charge higher interest rates or refrain from lending to them altogether." (Ibid., p.10).

102 "As SMEs are often not required to adopt international accounting Standards when preparing their financial statements, large discrepancies arise in the ways firms reports their financial positions. (...) Auditing such statements can be labor and time-intensive, which raises the cost of loan processing for SMEs. "(Ibid., p.11). 
Um trabalho bastante interessante realizado com analistas de instituições financeiras, que possuem como clientes as PMEs, que por sua vez dependem dos créditos fornecidos pelo sistema bancário na Alemanha, também aponta este tipo de indício. Por meio de questionários, Zuelch e Burghardt (2010) fizeram basicamente três perguntas: (a) durante o processo de análise de crédito, em que extensão as demonstrações contábeis eram ajustadas aos IFRS, e que ajustes eram extremamente necessários? ${ }^{103}$; (b) a transição das demonstrações para o IFRS gera vantagens ou desvantagens em termos de 'rating'? ${ }^{104,105}$; e principalmente, (c) os bancos alemães irão dar melhor avaliação a negócios que tenham migrado ao IFRS que a negócios com demonstrações de acordo com a Lei comercial? ${ }^{106}$ (p. 45).

Os resultados da pesquisa foram os seguintes: para a primeira questão verificou-se que

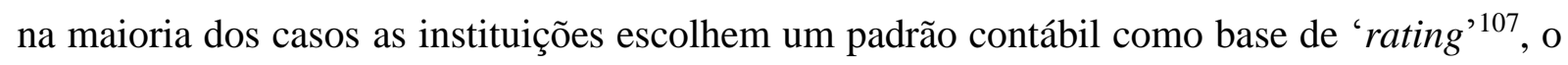
total de 65,5\% usam uma demonstração padronizada de acordo com o código comercial, apenas $7 \%$ afirmaram usar o padrão IFRS ${ }^{108}$.

Com relação aos ajustes, pelo menos algumas vezes as instituições ajustavam suas ferramentas de análise para informações fornecidas pelo IFRS ${ }^{109}$.

Quanto ao segundo questionamento, 28,9\% dos participantes concordam que a divulgação de uma demonstração em IFRS não estaria conectada a vantagens na análise de concessão de crédito, 31,2\% acreditavam que dariam pequenas margens de vantagens, no entanto, $12 \%$ acreditavam que seus clientes haveriam de ter vantagens na decisão de emprestar da instituição financeira ${ }^{110}$.

103 "During the process of the granting of loans, to what extent are the provided financial statements, or the tools used to analyze them, adjusted to IFRS, and which adjustments are deemed necessary?"

104 Termo usado para classificação de riscos de empresas (Securato, 2012, p.59)

105 "Does the transition of financial reporting to IFRS create advantages or disadvantages for an enterprise in terms of the rating?"

106 "The third and determining question is, will German banks generally give a better rating to a business which has transferred to IFRS than to a business which generates its financial reports according to commercial law" (Kruth, 2006, citado por Zuelch e Burghardt, 2010, p. 45)

107 "[...] the analysis confirms that institutions of all sizes in at least some of the cases choose the approach of issuing a standard balance sheet as basis for rating”.

108 "[...], 65.5 per cent used a standardized statement in accordance with commercial law. Only 7 per cent of those questioned stated that their institution used the IFRS standard."

109 "[...] it can be stated that there were institutions of all sizes which at least sometimes adjusted their analytic tools to the information provided by IFRS" (Ibid., p. 53)

110 "The empirical results show that 28.9 per cent of those questioned (or 29.9 per cent of the area "front office") agree that the provision of an IFRS statement is not connected to advantages in the granting of loans 
E por fim, as expectativas dos participantes quanto à melhor avaliação dos negócios, apenas $4,7 \%$ acredita bastante que os bancos irão dar melhor 'rating' a empresas que adotarem o IFRS, em contrapartida, $42 \%$ descartam essa possibilidade ${ }^{111}$. Quando a pesquisa divide em grupos de analistas que possuem mais ou menos conhecimentos em IFRS, as percepções melhoram substancialmente ${ }^{112}$ (Ibid., p.51).

Os autores concluem o artigo dizendo que foi demonstrado que para PMEs alemãs, a avaliação interna de crédito dos bancos pode sim ser uma motivação para uma alteração de sistema contábil do padrão nacional para internacional, além de que, a mudança pode exercer um efeito positivo na decisão de emprestar do banco, ao informar ao banco que a empresa possui um departamento contábil bem organizado ${ }^{113}$, e surpreendentemente, essas empresas, em alguns casos podem até esperar um bônus no 'rating' no preço do crédito, caso forneçam a demonstração financeira em IFRS ${ }^{114}$.

Embora, os aspectos apresentados acima reflitam situações de diferentes pontos de vista, porque se colocam dentro de diferentes países, muitas vezes com culturas empresariais diferentes, evoluções de evidenciação contábil desiguais no tempo, enfim, variáveis que influem decisivamente para a estruturação de um arcabouço normativo contábil, é interessante ver como essas culturas empresariais ímpares lidam com dificuldades diante de um ideal de padronização contábil.

(Massenberg and Borchardt, 2007, citados por Zuelch e Burghardt, 2010, p. 54). A further 31.2 per cent (29.9 per cent) of participants at least think that such advantages "hardly" exist. However, the results also show that a proportion of creditors do not agree with this view: in the case of 12 per cent (15.6 per cent) of the participants in the survey, clients can except an advantageous lending decision if they provide an IFRS statement."

111 "[...] a significant proportion of those questioned does perceive a positive effect on a risk-adjusted pricing as more or less possible. 4.7 per cent (6.3 per cent for the area of "front office") even believe it "always" to be the case. In contrast, 42 per cent (41.8 per cent) strictly rule out this possibility”. (Zuelch e Burghardt., 2010, p. 54)

112 "Amazingly, the proportion of those considering an improvement of the conditions "mostly" possible increases, as demonstrated in Table IV, when examining the cluster of those participants with a good or very good knowledge of IFRS. On the other hand, 73.3 per cent of those participants who have no knowledge of IFRS cannot imagine that a change in the accounting systems might lead to improved credit conditions. It seems obvious that the know-how has a significant impact on the participants' view on this subject"'(Ibid., p. 54)

113 “. [...], it could be demonstrated that for SMEs in Germany, the bank internal rating can be a motivation to change the system of financial reporting from national to international standards. Thus, the provision of an IFRS statement might in some cases exert a signal effect on the lending decision, for example by proving that a company's accounting department is well organized." (Ibid., pp. 55-56)

114 "Surprisingly, however, enterprises can in some cases even expect a "rating bonus" in the pricing of the credit, if they provide an IFRS statement." (Ibid., p. 56) 


\section{MÉTODO DE PESQUISA}

\subsection{Classificação da pesquisa}

A presente pesquisa foi conduzida por uma abordagem teórico-empírica, com uso de técnicas de avaliação qualitativa, associadas a técnicas quantitativas. Conforme sugerem Martins e Theóphilo (2009): “Do ponto de vista teórico, a abordagem qualitativa se justifica quando: dispõe-se de pouca informação a respeito do assunto a ser pesquisado, sendo necessário explorar o conhecimento que as pessoas têm com base em suas experiências e senso comum" (pp. 141/142).

Primeiramente, foram realizados procedimentos de pesquisa documental, ao procurar nos documentos acessórios aos normativos emitidos pelo IASB ("Discussion Papers", "Exposure Drafts" e "Basis for Conclusions"), utilizados como base para elaboração da norma contábil internacional para pequenas e médias empresas, o histórico dos acontecimentos que se sucederam antes da publicação da norma e os objetivos pretendidos pelo órgão normatizador ao desenvolvê-la.

Também foram revisitadas as normas brasileiras para trazer ao trabalho a recepção da norma internacional (IFRS for SMEs) emitida pelo CPC (Comitê de Pronunciamentos Contábeis) no caso brasileiro.

Em um segundo momento, realizou-se uma revisão da literatura ao pesquisar argumentos favoráveis e contrários à adoção das IFRS para PMEs, em livros, artigos publicados em periódicos, revistas e jornais recentemente, e defesas de dissertações e teses na Academia, tanto no Brasil como no mundo.

Partindo do referido levantamento, procurou-se elencar esses argumentos para identificar as evidências de relacionamento da nova norma com a teoria da contabilidade, principalmente no que se refere à assimetria informacional e à relação de custo-benefício, e a realidade dos processos de análise de concessão de crédito das instituições financeiras brasileiras para pequenas e médias empresas brasileiras, configurando-se assim a plataforma teórica da pesquisa. 
A empiria do estudo fica caracterizada em etapa posterior da pesquisa, em que foram coletados dados primários de empresas de pequeno e médio porte e de instituições bancárias, identificando evidências práticas acerca do uso do novo padrão contábil pelas PMEs e sobre as percepções e expectativas dos bancos quanto à adoção da nova norma e seus efeitos nos custos do crédito bancário provido pelas instituições financeiras.

Portanto, o trabalho teve por objetivo relacionar a prática contábil das pequenas e médias empresas com seus efeitos pragmáticos nos créditos bancários a elas concedidos, mais especificamente, nos custos de capital de terceiros provenientes de instituições bancárias. Ou seja, buscou-se verificar se a partir de um novo ambiente de padrão contábil, os custos das taxas cobradas para esse segmento se reduzem.

\subsection{Coleta de demonstrações financeiras de PMEs}

A pesquisa de campo se iniciou com o levantamento das demonstrações contábeis referentes aos anos de 2009, 2010 e 2011 das empresas da base de dados da FIPECAFI, que abrange o acervo de demonstrações financeiras das empresas do anuário 'Melhores \& Maiores' desenvolvido pela Revista Exame.

Segundo a Revista Exame (2012, p. 270), trata-se de dados de mais de 3.000 empresas, que compreende todas aquelas que publicaram suas demonstrações no Diário Oficial dos seus respectivos estados até determinado dia, assim como companhias limitadas que enviaram seus resultados para a análise de 'Melhores \& Maiores'.

Deste universo, foram selecionadas as empresas enquadradas no conceito de 'Pequenas e Médias Empresas' utilizado pelo CPC-PME e que não fossem elegíveis à categorização de empresas de grande porte conforme prescrito pela Lei 11.638/2007, na qual assim se classificam as empresas que têm ativo total superior a $\mathrm{R} \$ 240$ milhões ou receita bruta anual superior a $\mathrm{R} \$$ 300 milhões.

Para restringir ainda mais a amostra e alinhar a pesquisa com a análise qualitativa baseada nas entrevistas com as áreas de crédito para "Middle-Market" nas instituições financeiras, 
também foram retiradas as empresas conceituadas como microempresas e empresas de pequeno porte conforme o Estatuto da Micro e Pequena empresa, ou seja, empresas que tivessem receita bruta anual inferior a $\mathrm{R} \$ 3,6$ milhões.

Portanto, a seleção resultou em uma amostra não probabilística, uma vez que são verificados os balanços de todas as empresas elegíveis ao CPC-PME, que enviaram seus balanços à Revista Exame nos três últimos anos. Logo, trata-se de uma amostragem por acessibilidade ou conveniência, geralmente utilizada em pesquisas de caráter exploratório ou qualitativo, em que há uma cobrança menor no nível de precisão dos dados (Beuren, 2010, p. 126).

Este procedimento de verificação teve como objetivo encontrar evidências que demonstrassem mudanças de práticas contábeis e adequação às normas emanadas pelo CPC-PME, nas demonstrações contábeis preparadas antes das mudanças na legislação contábil para pequenas e médias empresas nos balanços de 2009, comparativamente aos balanços de 2010 e 2011. Além disso, procurou-se verificar a qualidade das demonstrações financeiras dessas empresas, uma vez que se acredita que um novo padrão traga consigo um ganho de qualidade das informações.

Tratou-se, portanto, de uma análise de conteúdo dos balanços contábeis dessas empresas, da qual se pode demonstrar os efeitos sob a forma de análises de estatística descritiva e inferencial.

Segundo Martins e Theóphilo (2009),

\begin{abstract}
a análise de conteúdo busca a essência de um texto nos detalhes das informações, dados e evidências disponíveis", e ainda, essa análise compreenderia três etapas: (a) pré-análise: coleta de organização do material a ser analisado; (b) descrição analítica: estudo aprofundado do material, orientado pelas hipóteses e referencial teórico. Escolha da unidade de análise (palavra, frase, símbolos, etc.). Essas unidades são juntadas segundo algum critério e definem as categorias. (...) As categorias devem ser exaustivas e mutuamente excludentes. Das análises de frequências das categorias surgem quadros de referências; e, (c) interpretação inferencial: com os quadros de referência, os conteúdos (manifesto e latente) são revelados em função dos propósitos do estudo (p. 99).
\end{abstract}

No que se refere à descrição analítica referida acima, foram verificadas nos balanços das empresas, referências ligadas aos seguintes itens:

- $\quad$ Norma: evidenciação do CPC-PME como norma de conformidade das demonstrações contábeis nas notas explicativas; 
- $\quad$ Ativo imobilizado: utilização do custo atribuído (deemed cost) na primeira adoção do CPC-PME; e utilização de depreciação conforme vida útil econômico em detrimento da vida útil fiscal;

- $\quad$ Ativo intangível: utilização da rubrica antes não utilizada; e amortização de vida útil do ativo em até 10 anos;

- $\quad$ Estoques: forma de mensuração de estoques com base no valor justo; caducidade do método UEPS como método de avaliação de estoques;

- $\quad$ Capital de terceiros: evidenciação do endividamento; e não capitalização dos juros no passivo da empresa;

- $\quad$ Notas explicativas: evidenciação;

- $\quad$ Auditoria independente: evidenciação de realização de procedimentos de auditoria e apresentação de parecer.

É importante atentar também que diversas das empresas analisadas não necessariamente possuíam todos os itens de verificação, i.e. estoques, ativo intangível, ativo imobilizado, etc., e que esses pontos foram ser devidamente ajustados na verificação, a fim de realizar uma análise mais acurada.

Logo, os itens acima foram tabulados em planilhas eletrônicas em conformidade com sua divulgação, para facilitar a interpretação dos dados. Nesse sentido os itens serão classificados em: (a) atende a evidenciação exigida pelo padrão do CPC; (b) não atende a evidenciação exigida pelo padrão do CPC; ou (c) não se aplica (N/A), por não haver a necessidade de registro e/ou evidenciação em certas contas em determinadas empresas (i.e. estoques em empresas prestadoras de serviços).

Embora esta pesquisa não tivesse por finalidade a formação de uma base de dados com abordagem unicamente quantitativa, as estatísticas descritivas e inferenciais ajudaram na identificação de tendências ligadas às alterações na norma e nível de adoção do padrão contábil internacional nas empresas verificadas.

\subsection{Modelo empírico}

\subsubsection{Variáveis exploradas por métodos quantitativos}




\subsubsection{Custo de crédito bancário como variável dependente}

Para explorar o custo de crédito bancário das empresas, foram usadas três distintas proxies $^{115}$ com bases contábeis. O uso de proxies múltiplas ajuda a generalizar os resultados.

As variáveis escolhidas foram as seguintes:

(a) o quociente entre despesas financeiras (DF) registradas na demonstração de resultados líquidas de impostos ${ }^{116}$ no período e o saldo do passivo financeiro no final do ano, também utilizado em Lima (2007), em análise de impacto de evidenciação contábil no custo de crédito de empresas de capital aberto.

$$
I_{1}=\frac{\left[D F_{t}(1-0,34)\right]}{\text { Passivo Financeiro }_{t}}
$$

(b) o quociente entre despesas financeiras (DF) registradas na demonstração de resultados líquidas de impostos no período e o saldo em capital de terceiros no final do período.

$$
I_{2}=\frac{\left[D F_{t}(1-0,34)\right]}{\text { Capital de Terceiros }_{t}}
$$

(c) o quociente entre despesas financeiras (DF) registradas na demonstração de resultados líquidas de impostos no período e o patrimônio líquido (PL) médio entre o ano anterior e o ano corrente, a análise deste índice tem o propósito de aferir a eficiência na alocação de recursos aportados de terceiros e seu impacto sobre o capital próprio. Empresas desse segmento podem manter alto volume de despesas financeiras (principalmente por conta de utilização de capital de giro), sem necessariamente manter saldo em empréstimos nos finais de período. Este índice foi inserido para captar essas situações.

$$
I_{3}=\frac{\left[D F_{t}(1-0,34)\right]}{\left[\left(P L_{t}+P L_{t-1}\right) / 2\right]}
$$

115 Proxies são medidas reais que representam conceitos teóricos.

${ }^{116}$ Foi utilizada alíquota de $34 \%$. 


\subsubsection{Variáveis independentes sujeitas aos testes de hipóteses}

Para investigar o impacto da adoção de um padrão contábil internacional nos custos dos créditos bancários tomados pelas empresas de pequeno e médio porte, foram escolhidas como objeto dos testes de hipóteses as variáveis: (a) nível de evidenciação contábil e (b) adoção de um padrão contábil internacional.

\subsection{Nível de evidenciação contábil (disclosure)}

Pacter (2010) defende com base nas evidências encontradas nos estudos de Chen et al. (2010) e Hope et al. (2010) que a qualidade das demonstrações financeiras e a transparência financeira afetam positivamente a eficiência de alocação de capital em mercados emergentes, ou seja, informação com melhor qualidade produz efeito no custo de capital das pequenas e médias empresas.

Neste sentido, uma vez que o novo padrão de contabilidade introduzido com o CPCPME exige um maior nível de evidenciação contábil e consequentemente uma maior qualidade e transparência da informação, acredita-se que quanto maior a evidenciação contábil, mais aderente ao novo padrão contábil estará a empresa que melhor informar sobre sua situação econômico-financeira.

Para mensurar esse nível de disclosure, utilizou-se a mesma técnica empregada por Lopes e Rodrigues (2007, p. 42) em seu trabalho de análise de aderência de disclosure requerido pelas IAS 32 e IAS 39, específico para instrumentos financeiros, e também por Lima (2007).

Esses autores construíram índices baseados em categorias de evidenciação com itens de verificação, caracterizados por serem dicotômicos ( 1 se foi evidenciado e 0 se não), sem pesos (mesmo considerando uma premissa com distorções, Lopes e Rodrigues (2007, p. 42) acreditavam que o viés seria menor que uma atribuição de pesos, baseado em outros estudos anteriores $^{117}$ ), e ajustados por itens não aplicáveis.

Logo o escore total seria dado pela somatória dos itens evidenciados por empresa $i$, no ano $t$ :

${ }^{117}$ Robbins \& Austin (1986), Cooke (1989), Cooke (1993), Meek \& Roberts (1995), Raffournier (1995) Inchausti (1997) e Chalmers \& Godfrey (2004), todos citados por Lopes e Rodrigues (2007, p. 42). 


$$
T_{i, t}=\sum_{j=1}^{m} d_{j}
$$

em que $d_{j}$ é o item evidenciado e $m$ o número de itens verificáveis para todas as companhias.

O escore ajustado seria dado por:

$$
M_{i, t}=\sum_{j=1}^{n} d_{j}
$$

em que $d_{j}$ é o item evidenciado e $n$ o número de itens aplicáveis para cada companhia $i$ especificamente, no ano $t$. Foram consideradas relevantes, e consequentemente aplicáveis ao referido índice, as rubricas contábeis que ultrapassassem 5\% do valor de ativo da empresa. Segundo Mackenzie et al. (2013, p. 40), preparadores e auditores eventualmente adotam a regra de que qualquer item abaixo de $5 \%$ do ativo ou receita líquida é considerado imaterial.

Logo o índice de disclosure de uma empresa $i$ no ano $t$ seria dado pelo quociente entre o escore total e o escore ajustado demonstrado acima:

$$
\operatorname{discl}_{i, t}=\frac{T_{i, t}}{M_{i, t}}
$$

Os itens de verificação de evidenciação, caracterizados por serem dicotômicos (1 se foi evidenciado e 0 se não), com detalhamento dos componentes encontram-se no apêndice A desta dissertação.

\subsection{Adoção do padrão contábil internacional}

As demonstrações financeiras que possuem padrão internacional exigem evidenciação de notas explicativas, e por meio delas é possível identificar a base de normativos em que os balanços são apresentados.

Para representar a adoção do padrão contábil internacional, utilizou-se uma variável binária (dummy), denominada $D c p c$, que assume valor 1, caso a empresa tenha evidenciado o uso do padrão conforme as normas emitidas pelo CPC, fossem elas baseadas no Full IFRS ou no IFRS for SMEs, e valor 0, caso contrário. 


\subsubsection{Variáveis de controle}

Com o objetivo de controlar outros fatores relevantes que pudessem influenciar o custo das PMEs, diversas variáveis foram incluídas no modelo econométrico, varáveis essas que estariam associadas às características retiradas das demonstrações contábeis das empresas, assim como a fatores econômicos.

\subsection{Tamanho da empresa}

Embora as empresas da amostra já estejam segmentadas por nível de faturamento, se caracterizando por empresas de "Middle-Market", é possível que haja uma diferenciação entre empresas mais próximas ao nível de pequenas entidades e àquelas próximas ao patamar de grandes empresas.

Assume-se que uma empresa que tenha obtido um determinado crescimento a ponto de se aproximar ao porte de uma grande empresa, venha a obter patamares de taxas de juros menores em relação às empresas de menor porte. Logo, espera-se relação negativa entre custo de seus créditos bancários e seu tamanho.

O tamanho foi mensurado pelo valor contábil de suas receitas líquidas ao final do período.

$$
\text { size }_{i, t}=\text { faturamento líquido }_{i, t}
$$

em que $i$ corresponde à empresa e $t$ ao ano, size $e_{i, t}$ é o tamanho da empresa e faturamento líquido $o_{i, t}$ são as receitas líquidas.

\subsection{Rentabilidade}

Outra variável que pode interferir na avaliação de uma empresa é a sua capacidade de gerar resultados, reveladora de sua eficiência gerencial sobre os recursos captados. Espera-se que quanto melhores são seus índices de rentabilidade, maiores são as chances de repagamento de dívidas e menores seus custos de captação bancária. 
A rentabilidade sobre os recursos investidos na empresa foi medida pelo retorno (lucro líquido) sobre o patrimônio líquido $\left(\mathrm{ROE}^{118}\right)$.

$$
\operatorname{roe}_{i, t}=\frac{L L_{i, t}}{P L_{i, t-1}}
$$

em que $i$ corresponde à empresa e $t$ ao ano, roe $e_{i, t}$ é a retorno sobre o investimento na empresa, $L L_{i, t}$ é a representação do lucro líquido coletado das demonstrações de resultados das empresas e $P L_{i, t-1}$ é o patrimônio líquido das empresas no ano anterior ao ano analisado do retorno.

\subsection{Endividamento}

O nível de endividamento da empresa também influencia na análise de risco de uma empresa, e consequentemente no custo de captação bancária. As dívidas comprometem o fluxo de caixa devido suas exigibilidades contratuais, e na medida em que a companhia compromete seu patrimônio com dívida seu risco aumenta.

Espera-se que quanto mais endividada a empresa, mais dificuldades ela deverá encontrar para se endividar ainda mais, se traduzindo em aumento de risco e consequentemente aumento de custos financeiros, ou seja, espera-se uma relação diretamente proporcional entre dívida e o seu custo.

A variável foi medida pelo índice de endividamento geral que evidencia a dependência do capital de terceiros no financiamento da sociedade.

$$
\operatorname{debt}_{i, t}=\frac{K T_{i, t}}{\text { ativo total }_{i, t}}
$$

em que $i$ corresponde à empresa e $t$ ao ano, debt $t_{i, t}$ é o endividamento da empresa, $K T_{i, t}$ é a representação do capital de terceiros das empresas e ativo total $_{i, t}$ é o total de ativo das empresas no ano.

${ }^{118}$ Return over Equity 


\subsection{Auditoria independente}

Conforme visto anteriormente em Hope et al. (2010), a realização de trabalhos de revisão das demonstrações financeiras por auditores externos em empresas privadas se relaciona com a mitigação de restrições a capital de terceiros.

Para representar a realização de trabalho de revisão de auditoria independente, utilizouse uma variável binária (dummy), denominada Daudit, que assume valor 1, caso a empresa tenha evidenciado a realização dos trabalhos nas notas explicativas de suas demonstrações contábeis, e valor 0 , caso contrário.

Além disso, outros trabalhos como o de Albuquerque et al. (2010) sugerem que a revisão das demonstrações financeiras por auditores independentes externos conhecidos como "Big 4" (nomenclatura genérica dada às grandes firmas de auditorias Deloitte Touche Tohmatsu, Ernst \& Young, KPMG, e PriceWaterhouse Coopers) em empresas privadas, se relaciona com a mitigação de riscos para os investidores e credores.

Para representar a realização de trabalho de revisão de auditoria independente por essas empresas de auditoria especificamente, utilizou-se uma variável binária (dummy), denominada Dbig4, que assume valor 1, caso a empresa tenha evidenciado a realização dos trabalhos com uma das empresas citadas acima nas notas explicativas de suas demonstrações contábeis, e valor 0 , caso contrário.

Espera-se que quanto mais revistas as demonstrações contábeis das companhias, melhor custo de crédito essas empresas haverão de ter, uma vez que informações confiáveis se traduziriam, em tese, em menor risco para os credores.

\subsection{Variáveis econômicas}

Fatores econômicos também afetam os custos de captação de recursos bancários, como por exemplo, alterações nas taxas básicas de juros e nas taxas de câmbio, ou mesmo um aumento de concorrência bancária.

Para captar as influências econômicas sofridas por todas as empresas ocorridas em função do tempo, uma variável binária (dummy) foi incluída no modelo. A variável dummy de ano é definida como $t=0$, para o ano de 2010 e $t=1$, para o ano de 2011. 
O ano de 2009 não foi considerado, uma vez que o custo de captação é uma função de diversas variáveis do ano anterior, ou seja, exemplificando, a divulgação de 2009 pode afetar o custo de captação em 2010. Logo, somente são usados na análise os anos de 2010 e 2011.

\subsection{Setor da economia}

As diferenças mercadológicas entre setores da economia também podem afetar os custos de captação da empresa.

Para captar as influências econômicas em função da localização da empresa, quatro variáveis binárias (dummies) foram incluídas no modelo, denominadas de Dsector $k$. As variáveis dummy de região são definidas como Dsector $_{1}=1$, para o setor de serviço, e Dsector $1=0$, para os outros setores da economia, e assim sucessivamente os setores de agronegócios, indústria de bens de consumo e indústria de bens de capital.

O setor de atividade comercial foi a setor escolhido como referência para análise em relação aos outros quatro. A segregação setorial utilizada encontra-se na estatística descritiva (seção 4.1).

\subsection{Região geográfica}

As diferenças mercadológicas entre regiões geográficas também podem afetar os custos de captação da empresa.

Para captar as influências econômicas em função da localização da sede da empresa, três variáveis binárias (dummies) foram incluídas no modelo, denominadas de Dregion $_{m}$. As variáveis dummy de região são definidas como Dregion $_{1}=1$, para o a Região Sudeste, e Dregion $_{1}=0$, para outras regiões, e assim sucessivamente para as regiões Centro-Oeste e NorteNordeste.

A região Sul foi a região escolhida como referência para análise em relação às outras três. A segregação geográfica utilizada encontra-se na estatística descritiva (seção 4.1). 


\subsection{Relacionamento com as instituições financeiras}

O histórico de relacionamento com as instituições financeiras pode também influenciar significativamente nos custos de captação de crédito bancário, uma vez que essas empresas provavelmente já tenham passado por uma análise de crédito anteriormente e obtido sua classificação de crédito.

Para captar essa influência, assumiu-se que os índices que representam as custo de captação no ano anterior, $\mathrm{I}_{\mathrm{t}-1, \mathrm{i}}$, ou seja, as variáveis defasadas em um período, podem representar o relacionamento das empresas com as instituições bancárias.

\subsubsection{Hipóteses estatísticas}

A questão de pesquisa desenvolvida nesse trabalho, apresentada na introdução dessa pesquisa, relaciona a melhora na qualidade das informações contábeis das empresas, ou mesmo, a adoção de um padrão internacional de contabilidade pelas PMEs, com a redução no custo de créditos bancários por elas tomados em instituições financeiras.

Tal questão foi subdivida em duas hipóteses a fim de analisar por diferentes meios seus efeitos estatísticos.

Primeiramente, analisou-se se havia diferenças nas medianas dos custos de captação de crédito bancário em entre empresas com qualidade acima da média das empresas estudadas (grupo 1), e empresas abaixo da média (grupo 2), assim como as mesmas diferenças entre empresas que evidenciaram a adoção de um padrão contábil com base no CPC (grupo 1) ou não.

A avaliação dessas diferenças entre medianas permite a investigação das seguintes hipóteses:

Hipótese I: Empresas com melhor qualidade da informação contábil captam créditos bancários em melhores condições de custo que empresas com pior qualidade das informações contábeis.

Hipótese II: Empresas que evidenciam seu padrão contábil baseado nas normas emanadas pelo CPC captam créditos bancários em melhores condições de custo que empresas que não o evidenciam. 
Para os testes estatísticos foram usadas as seguintes hipóteses abaixo, sendo que ao rejeitar a hipótese estatística nula, as proposições metodológicas $\left(\mathrm{H}_{\mathrm{I}}\right.$ e $\left.\mathrm{H}_{\mathrm{II}}\right)$ acima $\underline{\mathbf{N} \tilde{A} \mathbf{O}}$ seriam rejeitadas.

$$
\begin{aligned}
& H_{0}: \tilde{\mu}_{1}=\tilde{\mu}_{2} \\
& H_{1}: \tilde{\mu}_{1}<\tilde{\mu}_{2}
\end{aligned}
$$

Em seguida, analisou-se a significância e o sinal dos parâmetros relacionados às variáveis também sujeitas aos testes anteriores, sendo que a variável associada à qualidade é o valor do índice de disclosure, e variável associada ao padrão contábil é uma variável dicotômica de evidenciação do padrão CPC, em uma regressão com dados em painel, os quais contemplam também as variáveis de controle anteriormente mencionadas.

A avaliação dos parâmetros permite a investigação das mesmas hipóteses, sob um prisma diferente, a hipótese I, em outras palavras, para melhor entendimento do teste, significaria dizer que o nível de qualidade da informação contábil tem relação significativa e inversamente proporcional com os custos dos créditos bancários.

Analogamente, a hipótese II, significaria dizer, que a evidenciação do padrão contábil baseado nas normas do CPC tem relação inversa com os custos dos créditos bancários.

Para os testes estatísticos foram usadas as seguintes hipóteses abaixo, sendo que ao rejeitar a hipótese estatística nula, as proposições metodológicas $\left(\mathrm{H}_{\mathrm{I}}\right.$ e $\left.\mathrm{H}_{\mathrm{II}}\right)$ acima seriam rejeitadas.

$$
\begin{aligned}
& H_{0}: \beta 1<0 \text { e } H_{0}: \beta 2<0 \\
& H_{1}: \beta 1 \geq 0 \text { e } H_{1}: \beta 2 \geq 0,
\end{aligned}
$$

em que os parâmetros $\beta 1$ e $\beta 2$ são os coeficientes das variáveis 'nível de disclosure' e 'evidenciação do padrão contábil com base nas normas do CPC', respectivamente. 


\subsubsection{Testes estatísticos}

\subsubsection{Testes de médias (Mann-Whitney)}

As variáveis escolhidas como objeto dos testes de hipóteses foram (a) nível de evidenciação contábil e (b) adoção de um padrão contábil internacional.

Os indivíduos da amostra foram categorizados em duas formas qualitativas. Na primeira classificação, com base no índice de disclosure, descrito no item 3.3.1.2.1, dividiu-se a amostra em empresas com índice de evidenciação acima da média total do ano analisado (grupo 1) e empresas com índice de evidenciação abaixo da média (grupo 2).

Na segunda ordenação, têm-se empresas que evidenciam a divulgação de suas demonstrações contábeis com base nos pronunciamentos do CPC (grupo 1) e, por outro lado, empresas que não evidenciam a base de preparo de suas demonstrações ou utilizam outras bases normativas que não o CPC (grupo 2) nos anos de 2009 e 2010 (ex. Lei das S/As.). Embora o CPCPME tenha entrado em vigor somente em 2010, muitas empresas desse segmento já evidenciavam suas demonstrações contábeis no padrão internacional do CPC em 2009, ainda que parcialmente adotado.

Os dois conjuntos de grupos de amostras independentes foram objeto dos testes não paramétricos de comparação das médias das proxies de custo de captação bancária $\left(\mathrm{I}_{1}, \mathrm{I}_{2}\right.$ e $\left.\mathrm{I}_{3}\right)$, para cada ano de divulgação (2009 e 2010), em sua totalidade, e também por atividade econômica e por região geográfica, ou seja, comparou-se a divulgação no anterior $\left(\mathrm{d}_{-1}\right)$ com as taxas de captação bancário no ano seguinte (d).

A versão não paramétrica do teste de médias para duas amostras independentes é o “Teste de Mann-Whitney”, o qual admite a violação da normalidade das amostras, existência de variâncias desiguais, e utilização em amostras pequenas (Stevenson, 1981, p. 317).

O teste consiste na substituição dos dados originais pelos seus respectivos postos ordenados (ranques) dos dois grupos de análise como se eles fizessem parte de uma única amostra. Considera-se $n_{1}$ o número de casos do grupo 1, que é aquele com menor quantidade de observações, e $n_{2}$ o número de casos do grupo 2. Coloca os dados em ordem crescente e atribui-se o posto 1 ao grupo com menor escore, e assim sucessivamente até atribuir posto ao número total 
de observações. Calcula-se primeiramente, a soma dos postos de cada grupo $R_{1}$ e $R_{2}$ e depois se calcula as estatísticas $U$ de Mann-Whitney a partir de $U_{1}$ e $U_{2}$, em que $U=\min \left(U_{1}, U_{2}\right)$ :

$$
U_{1}=n_{1} \cdot n_{2}+\left[\frac{n_{1}\left(n_{1}+1\right)}{2}\right]-R_{1}
$$

ou

$$
U_{2}=n_{1} \cdot n_{2}+\left[\frac{n_{2}\left(n_{2}+1\right)}{2}\right]-R_{2}
$$

A distribuição depende do valor de $N$, para $n_{1} \leq 10$ e $n_{2} \leq 10$, consulta-se as probabilidades exatas na tabela de Mann-Whitney, para $n_{1}>10$ ou $n_{2}>10$, a distribuição de MannWhitney se aproxima de uma distribuição normal padrão, conforme cálculo da estatística $z$ abaixo.

$$
z_{\text {calc }}=\frac{\left(U-n_{1} \cdot n_{2} / 2\right)}{\sqrt{\frac{n_{1} \cdot n_{2}}{N(N-1)} \cdot\left(\frac{N^{3}-N}{12}-\sum_{i=1}^{g} \frac{t_{i}^{3}-t_{i}}{12}\right)}}
$$

em que:

$\sum_{i=1}^{g} \frac{t_{i}^{3}-t_{i}}{12}$, é um fator de correção quando há empates;

$g=$ número de grupos de postos empatados

$t_{i}=$ número de observações empatadas no grupo i. (Fávero, 2009, pp. 163/164).

Caso a estatística z calculada seja menor que o escore $\mathrm{z}$ da tabela de nível de confiança (99\%, $95 \%$ ou 90\%) da distribuição normal padronizada, respectivamente os valores de $-2,34$, -1,64 e -1,29, rejeita-se a hipótese que a média do grupo 1 seja maior ou igual que a média do grupo 2, como se observa na figura gráfica 5 representada abaixo. 


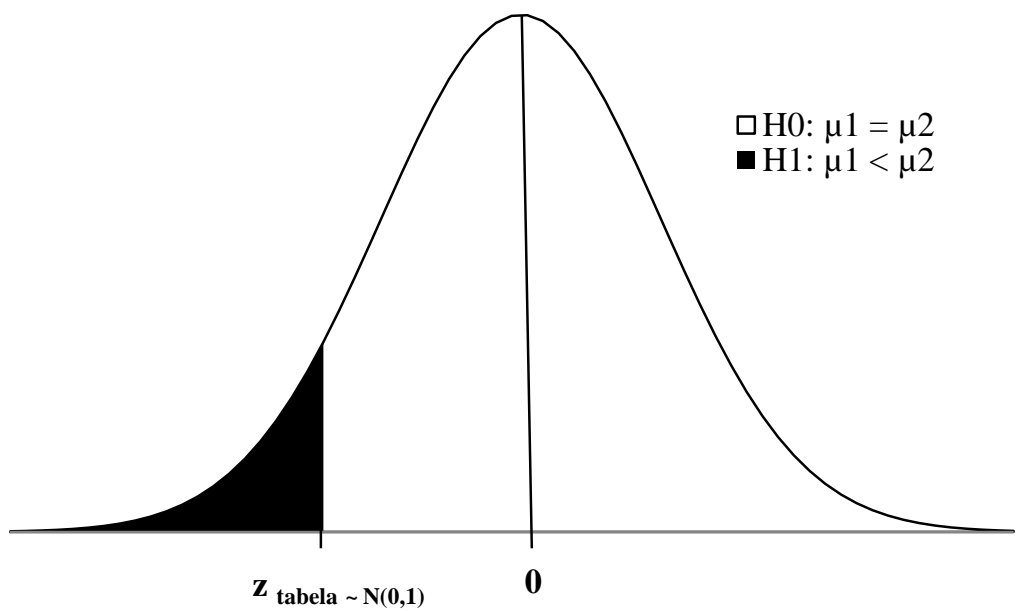

Figura 2 - Teste de Hipótese para diferença de medianas unilateral (Mann-Whitney)

O software usado ${ }^{119}$ calcula as estatísticas $U$ e $z$, e a probabilidade de não se rejeitar a hipótese nula ( $p$-value).

\subsubsection{Análise de dados em painel}

A hipótese formulada na pesquisa relaciona a adoção de um padrão contábil internacional pelas pequenas e médias empresas, e supostamente, um concomitante aumento na qualidade das informações contábeis, com uma redução nos custos do crédito bancário nas empresas brasileiras.

Para confirmar as hipóteses examinadas nos testes de médias propostos, sob um ponto de vista de um ângulo levemente diferente, foi especificado um modelo de regressão com dados em painel, em que são realizadas inferências sobre os parâmetros ( $\beta 1$ e $\beta 2)$ das variáveis de interesse: (a) qualidade de informações contábeis, discl e (b) evidenciação contábil, Dcpc.

Trata-se, portanto, de técnica de regressão multivariada que aglomera dados de crosssections $^{120}$ (ex. informações contábeis de diversas PMEs em um dado período) e séries temporais, especificamente nessa pesquisa, os anos de 2010 e 2011. Segundo Fávero (2009, p. 381), essa análise elabora um "mix" de duas abordagens permite o monitoramento de observações ao longo do tempo, e que segundo Pindyck e Rubinfeld (2004) e Gujarati (2006), como consequência, aumentam o número de observações, o número de graus de liberdade e a eficiência

${ }^{119}$ Os testes estatísticos foram realizados com auxílio do software SPSS ®, versão 21.

${ }^{120}$ Cortes transversais 
dos parâmetros, assim como reduzem problemas de multicolinearidade das variáveis independentes, citados por Fávero (2009, p. 319).

O modelo considera além das variáveis de interesse da pesquisa citadas acima, outras variáveis de controle, conforme descrito na equação a seguir:

$$
\begin{aligned}
I_{i, t, j}=\alpha+\beta 1 & \left(\operatorname{discl}_{i, t-1}\right)+\beta 2 \cdot\left(\text { Dcpc }_{i, t-1}\right)+\gamma 1 \cdot\left(\text { size }_{i, t-1}\right)+\gamma 2 \cdot\left(\text { roe }_{i, t-1}\right) \\
& +\gamma 3 \cdot\left(\text { debt }_{i, t-1}\right)+\gamma 4 \cdot\left(I_{i, t-1, j}\right)+\delta 1 \cdot\left(\text { Daudit }_{i, t-1}\right)+\delta 2 \cdot\left(\text { Dbig }_{i, t-1}\right) \\
& +\sum_{k=2}^{5} \varphi_{k} \cdot\left(\text { Dsector }_{k, i}\right)+\sum_{m=2}^{4} \omega_{m} \cdot\left(\text { Dregion }_{m, i}\right)+\psi t+\varepsilon_{i, t, j}
\end{aligned}
$$

em que $i$ corresponde à empresa, $t$ ao período, $\mathrm{j}$ ao tipo de proxy de custo de crédito $\left(\mathrm{I}_{1}, \mathrm{I}_{2}\right.$ ou $\left.\mathrm{I}_{3}\right)$, $\mathrm{k}$ representa o setor de atividade da empresa e m à região onde a sede da empresa se localiza.

A análise de dados em painel possui três abordagens mais comumente usadas: POLS (pooled ordinary least squares), efeitos fixos e efeitos aleatórios, o primeiro não considera a natureza de cada corte transversal estudado no tempo, trata-se de um modelo de mínimos quadrados empilhados, o modelo seria:

$$
Y=\alpha+\beta . X+\mu
$$

A segunda abordagem, efeitos fixos, considera os efeitos do tempo nos cortes transversais, leva em conta a individualidade de cada observação (interceptos diferentes para cada observação), o modelo poderia ser escrito como:

$$
Y_{i t}=\alpha_{1}+\beta_{1} \cdot X_{i t}+\mu_{i t}
$$

A abordagem de efeitos aleatórios acrescenta na abordagem de efeitos fixos um termo de perturbação por conta de eventual falta de informação, o modelo poderia ser escrito como:

$$
Y_{i t}=\alpha_{1}+\beta_{1} \cdot X_{i t}+w_{i t}
$$

em que, $w_{i t}=\varepsilon_{i}+\mu_{i t}$ (Fávero, 2009, p. 382). 
Para identificar as abordagens do modelo, devem ser aplicados os testes de definição de modelos, conforme segue (Ibid. p. 383).

Para a escolha entre o modelo POLS e o modelo de efeitos fixos utiliza-se o teste de Chow, que representa um teste F, cujas hipóteses são:

$\mathrm{H}_{0}$ : os interceptos são iguais para todos os cortes transversais (POLS)

$\mathrm{H}_{1}$ : os interceptos são diferentes para todos os cortes transversais (efeitos eixos)

O teste LM (Lagrange multiplier) de Breusch-Pagan avalia a adequação do modelo de efeito aleatório e o modelo POLS, o qual se utiliza de uma estatística de distribuição Qui-quadrado com 1 grau de liberdade, cujas hipóteses são:

$\mathrm{H}_{0}$ : a variância dos resíduos que refletem diferenças individuais é igual a zero (POLS).

$\mathrm{H}_{1}$ : a variância dos resíduos que refletem diferenças individuais é diferente de zero (efeitos aleatórios)

E por fim, o teste de Hausman, permite a escolha entre modelos de efeitos fixos e aleatórios, através de uma estatística com distribuição Qui-quadrado com número de graus de liberdade igual ao dimensionamento dos parâmetros (betas), cujas hipóteses são:

$\mathrm{H}_{0}$ : o modelo de correção de erros é adequado (efeitos aleatórios)

$\mathrm{H}_{1}$ : o modelo de correção de erros não é adequado (efeitos eixos)

Ademais os modelos de regressão com dados em painel também devem obedecer aos mesmos pressupostos do modelo clássico de regressão linear, ou seja, (a) os regressores devem ser adequados (lineares); (b) o erro deve ter distribuição normal (ausência de heterocedasticidade) e não apresentar autocorrelação com qualquer variável dependente; (c) o valor esperado de termo de erro é zero; e (d) não deve existir relação linear exata entre as variáveis dependentes, multicolinearidade (Kennedy, 2003, citado por Fávero, 2009, p. 356). 
Encontrados os modelos adequados, os parâmetros devem ser analisados, conforme estatística t calculada na regressão de cada variável, em que são analisados o sinal e a significância dos parâmetros, por meio de seus respectivos p-values.

\subsection{Entrevistas às instituições financeiras}

Depois da coleta das demonstrações contábeis e realização dos testes estatísticos, para se realizar uma triangulação de técnicas de coleta de dados, propôs-se realizar investigação utilizando a técnica de coleta de informações por meio de entrevistas.

Segundo Martins e Theóphilo (2009), no intuito de proporcionar uma base contextual mais rica para interpretação e validação de resultados, é comum se utilizar da triangulação, isto é, empregar métodos diferentes de coleta dos dados e comparar os resultados (p. 143).

Logo, a proposta da pesquisa foi de realizar entrevistas com gestores e diretores das áreas de análise de concessão de crédito a pequenas e médias empresas de instituições financeiras, tomando uma amostra não probabilística com cerca de oito a quinze instituições financeiras, com representação da área responsável por crédito a empresas de pequeno e médio porte, alocada no município de São Paulo ${ }^{121}$. Conforme os trabalhos de Godoi et al. (2006), na seleção de entrevistados, o desenho amostral não deve se preocupar com a representatividade estatística, além do mais é atribuída ao pesquisador a flexibilidade de voltar a campo e ampliar o número ou aprofundar a conversação com os participantes (p. 308).

A seleção da amostra foi realizada por meio de contatos profissionais de passado recente. Segundo Godoi et al. (Ibid.), a captura das instituições participantes da amostra deve se dar por meio de amigos, parentes, contatos pessoais conhecidos, seria difícil supor que o pesquisador de inserir-se-ia em espaço, na busca de entrevistados, que fosse completamente exterior ao mundo da vida e às redes sociais dos sujeitos (p. 309).

As entrevistas foram conduzidas com auxílio de uma pauta de entrevista (ver Apêndice B) enviada antecipadamente aos bancos, calcada no referencial teórico para encontrar respostas

${ }^{121}$ A delimitação da cidade se deve aos fatores de praticidade e viabilidade financeira, além da concentração bancária do país na cidade de São Paulo. 
sobre os processos de concessão de crédito utilizados e as expectativas em relação aos possíveis efeitos das mudanças introduzidas pelo CPC-PME, em função do problema a ser estudado.

Nesta pauta, foi ressaltada a função do entrevistador, em que segundo Sierra (1998, p. 314, citado por Godoi et al, p. 313), é formado uma espécie de acordo inicial, constando os seguintes pontos: os motivos e as intenções da investigação; o anonimato, a logística e devolução da informação.

Portanto, levando-se em consideração as questões adiantadas na pauta, a entrevista pôde ser caracterizada com o formato semiestruturado, guiada por um roteiro de perguntas que puderam ser mais profundamente exploradas no decorrer das conversas, com possibilidade de permitir a formulação de questionamentos adicionais (Godoi et al., 2006, p. 304).

Logo, além das questões enviadas na pauta da entrevista, também foram verificados os pontos acerca dos processos de concessão de crédito (riscos, garantias), critérios de classificação de PMEs e os modelos utilizados na avaliação de concessão de crédito, como análise de escore de crédito ou análise julgamental, para encontrar evidências do uso da contabilidade como ferramenta de análise de crédito. Segundo Beuren (2010), a entrevista semiestruturada, ao mesmo tempo em que valoriza o entrevistador, possibilita que o informante use toda a sua criatividade e espontaneidade, valorizando mais a investigação (p. 133).

Ademais foram exploradas as percepções das instituições financeiras quanto ao novo padrão contábil e suas consequências (transparência, custos, adaptação, acesso ao crédito, taxas de juros, etc.). Logo a entrevista teve o intuito de conhecer os procedimentos do banco no momento de analisar o crédito para PMEs e suas relações com a contabilidade, e não de montar um quadro de resultados quantitativos.

Martins e Theóphilo (2009) comentam que esse tipo de pesquisa se caracteriza pela predominância da descrição de pessoas, situações, acontecimentos, reações, inclusive transcrições de relatos, em que detalhes podem ser essenciais para o entendimento da realidade. Ademais, é importante observar como um fenômeno interage com os fatores e se manifesta nas atividades e nos procedimentos, os dados são analisados à medida que são coletados (Ibid., p. 141). 
E ainda afirmam que o processo de entrevistas deve considerar: (a) planejamento, com cuidadoso delineamento do objetivo; (b) obtenção de prévio conhecimento do entrevistado; (c) atenção aos itens que o entrevistado deseja esclarecer, sem manifestação de opinião; (d) obtenção e manutenção da confiança do entrevistado; (e) ouvir mais que falar; (f) atenção com eventuais divagações; (g) registro das informações durante a entrevista; (h) uso de gravador, com aquiescência do entrevistado, e (j) formulação de questões secundárias se necessárias (Ibid., p. 89).

Portanto, a partir das percepções coletadas procurou-se relacionar o nível de adoção das práticas contábeis determinadas pelo CPC-PME nas empresas no Brasil com os efeitos em termos de custos do crédito bancário para o segmento analisado, assim como o nível de acesso ao crédito bancário, primeiramente com a verificação dos balanços das PMEs, com posterior complemento de entrevistas a algumas instituições financeiras. 


\section{RESULTADOS}

\subsection{Análises quantitativas}

Antes dos resultados propriamente ditos, com intuito de verificar a confiabilidade da medida de disclosure desenvolvida no trabalho, foi calculado o Alfa de Cronbach do instrumento de medição desenvolvido. Conforme Martins e Theóphilo (2009, p. 15), quando o coeficiente for superior a 70\%, diz-se que a medida é confiável. Seu cálculo é dado pela expressão:

$$
\propto=\frac{N \bar{\rho}}{[1+\bar{\rho}(\mathrm{N}-1)]}
$$

em que:

$\alpha=$ alfa de Cronbach;

$\mathrm{N}=$ número de itens;

$\bar{\rho}=$ média dos coeficientes de correlação linear (Pearson) entre os itens.

Para o índice desenvolvido, em função dos 25 itens analisados $(\mathrm{N})$, o $\bar{\rho}$ calculado, com a média das correlações dos escores de cada item com os escores dos demais itens, foi de 0,5917, o que resultou em um alfa de Cronbach de 97,31\%, validando o instrumento.

\subsubsection{Estatística descritiva}

Primeiramente são apresentadas as estatísticas descritivas das variáveis brutas, ou seja, sem nenhuma espécie de tratamento estatístico, referentes às demonstrações contábeis de todas as empresas examinadas durante os três anos de análise.

A lista de empresas com o padrão de tamanho solicitado à FIPECAFI (mantenedora da base de dados utilizada para a elaboração da Revista Melhores \& Maiores), ou seja, que não se configuravam como empresas de grande porte (Lei n. 11.638/07) por faturamento e tamanho de ativo, nem microempresas e empresas de pequeno porte conforme Lei complementar 123/06, nos anos de 2009, 2010 e 2011, resultou num total de 195 empresas, das quais 16 foram excluídas da análise por se tratarem de empresas cooperativas (15) e de previdência (1), não sujeitas ao padrão CPC-PME, restando um total de 179 empresas. As tabelas a seguir apresentam as estatísticas descritivas das variáveis da pesquisa, em cada ano. 
Tabela 3 - Estatísticas Descritivas das Variáveis de 2009

\begin{tabular}{|c|c|c|c|c|c|c|c|}
\hline Ano 2009 & $\mathrm{~N}$ & Média & Mediana & Mínimo & Máximo & $\begin{array}{c}\text { Desvio } \\
\text { Padrão }\end{array}$ & $\begin{array}{c}\text { Coef. de } \\
\text { Variação }\end{array}$ \\
\hline I1 & 179 & 0,40 & 0,10 & 0,00 & 11,99 & 1,37 & 3,45 \\
\hline I2 & 179 & 0,05 & 0,04 & 0,00 & 0,45 & 0,06 & 1,12 \\
\hline I3 & 179 & 0,10 & 0,04 & $(8,99)$ & 7,85 & 0,91 & 9,19 \\
\hline Faturamento (R\$ mil) & 179 & 143.859 & 141.258 & 24.553 & 297.828 & 58.183 & 0,40 \\
\hline Ativo (R \$ mil) & 179 & 101.047 & 100.975 & 15.982 & 212.730 & 46.070 & 0,46 \\
\hline ROE & 179 & 0,13 & 0,13 & $(5,59)$ & 1,95 & 0,71 & 5,57 \\
\hline Endividamento & 179 & 0,67 & 0,55 & 0,15 & 11,48 & 0,90 & 1,36 \\
\hline Auditoria & 179 & 0,44 & 0,00 & 0,00 & 1,00 & 0,50 & 1,14 \\
\hline Big Four & 179 & 0,15 & 0,00 & 0,00 & 1,00 & 0,35 & 2,43 \\
\hline CPC & 179 & 0,35 & 0,00 & 0,00 & 1,00 & 0,48 & 1,38 \\
\hline Disclosure & 179 & 0,52 & 0,58 & 0,00 & 1,00 & 0,32 & 0,61 \\
\hline
\end{tabular}

Para o primeiro ano, 2009, o padrão contábil CPC-PME ainda não estava em vigor, no entanto, 35\% das empresas estudadas, embora não necessitassem, já apresentavam suas demonstrações contábeis com base nas normas do CPC voluntariamente, ainda que a adoção do padrão contábil internacional fosse parcial até esse momento.

Tabela 4 - Estatísticas Descritivas das Variáveis de 2010

\begin{tabular}{|c|c|c|c|c|c|c|c|}
\hline Ano 2010 & $\mathrm{N}$ & Média & Mediana & Mínimo & Máximo & $\begin{array}{c}\text { Desvio } \\
\text { Padrão }\end{array}$ & $\begin{array}{c}\text { Coef. de } \\
\text { Variação }\end{array}$ \\
\hline I1 & 179 & 0,79 & 0,10 & 0,00 & 64,42 & 5,15 & 6,48 \\
\hline I2 & 179 & 0,04 & 0,04 & 0,00 & 0,26 & 0,03 & 0,83 \\
\hline I3 & 179 & 0,11 & 0,04 & $(0,59)$ & 3,58 & 0,33 & 2,88 \\
\hline Faturamento (R\$ mil) & 179 & 167.795 & 167.069 & 58.027 & 294.478 & 64.706 & 0,39 \\
\hline Ativo (R\$ mil) & 179 & 117.054 & 117.889 & 21.284 & 226.640 & 48.617 & 0,42 \\
\hline ROE & 179 & 0,14 & 0,16 & $(3,69)$ & 1,77 & 0,45 & 3,13 \\
\hline Endividamento & 179 & 0,61 & 0,54 & 0,07 & 7,05 & 0,55 & 0,90 \\
\hline Auditoria & 179 & 0,49 & 0,00 & 0,00 & 1,00 & 0,50 & 1,03 \\
\hline Big Four & 179 & 0,16 & 0,00 & 0,00 & 1,00 & 0,37 & 2,28 \\
\hline CPC & 179 & 0,53 & 1,00 & 0,00 & 1,00 & 0,50 & 0,94 \\
\hline CPC-PME & 179 & 0,11 & 0,00 & 0,00 & 1,00 & 0,31 & 2,91 \\
\hline Disclosure & 179 & 0,58 & 0,63 & 0,00 & 1,00 & 0,31 & 0,53 \\
\hline
\end{tabular}


Tabela 5 - Estatísticas Descritivas das Variáveis de 2011

\begin{tabular}{|c|c|c|c|c|c|c|c|}
\hline Ano 2011 & $\mathrm{~N}$ & Média & Mediana & Mínimo & Máximo & $\begin{array}{c}\text { Desvio } \\
\text { Padrão }\end{array}$ & $\begin{array}{c}\text { Coef. de } \\
\text { Variação }\end{array}$ \\
\hline I1 & 179 & 0,48 & 0,09 & 0,00 & 14,51 & 1,94 & 4,02 \\
\hline I2 & 179 & 0,05 & 0,04 & 0,00 & 0,23 & 0,04 & 0,83 \\
\hline I3 & 179 & 0,09 & 0,05 & $(6,40)$ & 1,57 & 0,54 & 6,17 \\
\hline Faturamento (R\$ mil) & 179 & 185.887 & 185.823 & 51.152 & 299.384 & 67.467 & 0,36 \\
\hline Ativo (R\$ mil) & 179 & 130.196 & 133.688 & 15.826 & 234.194 & 51.097 & 0,39 \\
\hline ROE & 179 & 0,16 & 0,15 & $(1,33)$ & 4,08 & 0,48 & 2,94 \\
\hline Endividamento & 179 & 0,63 & 0,58 & 0,07 & 7,35 & 0,58 & 0,92 \\
\hline Auditoria & 179 & 0,54 & 1,00 & 0,00 & 1,00 & 0,50 & 0,92 \\
\hline Big Four & 179 & 0,20 & 0,00 & 0,00 & 1,00 & 0,40 & 2,00 \\
\hline CPC & 179 & 0,60 & 1,00 & 0,00 & 1,00 & 0,49 & 0,81 \\
\hline CPC-PME & 179 & 0,11 & 0,00 & 0,00 & 1,00 & 0,32 & 2,83 \\
\hline Disclosure & 179 & 0,63 & 0,72 & 0,00 & 1,00 & 0,29 & 0,45 \\
\hline
\end{tabular}

Verifica-se que, em média, essas empresas tiveram crescimento em faturamento e ativo, assim como em rentabilidade. O grau de endividamento caiu em 2010, e voltou a subir em 2011. E ao observar os índices de taxa de captação bancária, ainda não se pode observar nenhum tipo de tendência, eles se comportam de maneira deveras heterogênea.

No que se refere ao CPC-PME propriamente dito, percebe-se que adoção do padrão foi observada nos anos de 2010 e 2011, a partir da entrada em vigor da Resolução CFC nº $1255 / 09$, porém o grau de implementação da norma é ainda incipiente, apenas 11\% em média.

No entanto, percebe-se que as empresas desde 2009 vêm aumentando seus níveis de adequação aos padrões internacionais, pelo menos em rótulo, uma vez que a evidenciação do padrão contábil com base nas normas do CPC (incluindo tanto CPC-PME como CPC completo) vem aumentando a cada ano, muitas vezes voluntariamente, uma vez que esse universo de empresas não exige a divulgação das demonstrações contábeis com base nas IFRS completas.

Os níveis de auditoria independente no mercado, de contratação de empresas de auditoria 'Big Four' especificamente, assim como os níveis de disclosure também tiveram aumento na média dos anos.

As regiões geográficas da amostra são apresentadas conforme tabela abaixo: 


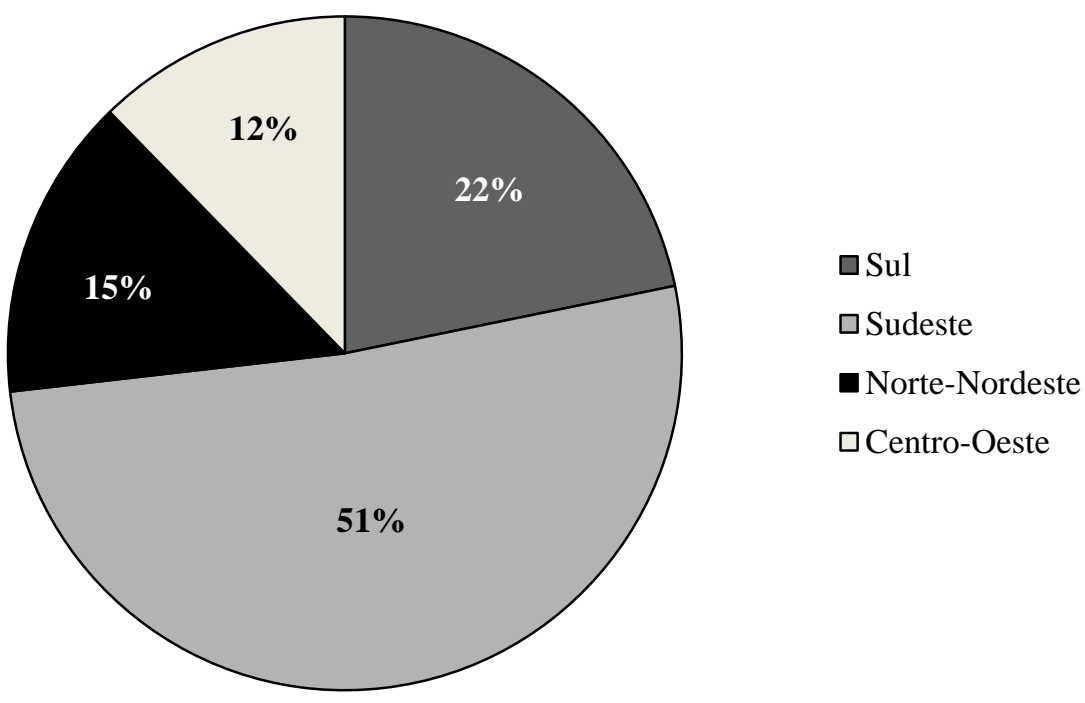

Gráfico 6 - Distribuição Geográfica da Amostra (Percentual)

Fonte: elaborado pelo autor

Vê-se maior representatividade da região Sudeste, com $51 \%$ do total de empresas da amostra, seguida da região Sul com $22 \%$. Havia somente duas empresas na região Norte, razão pela qual, a região foi inserida na região Nordeste (15\%), no mesmo formato das análises realizadas pela Revista Exame Melhores e Maiores Exame (2012, p. 574).

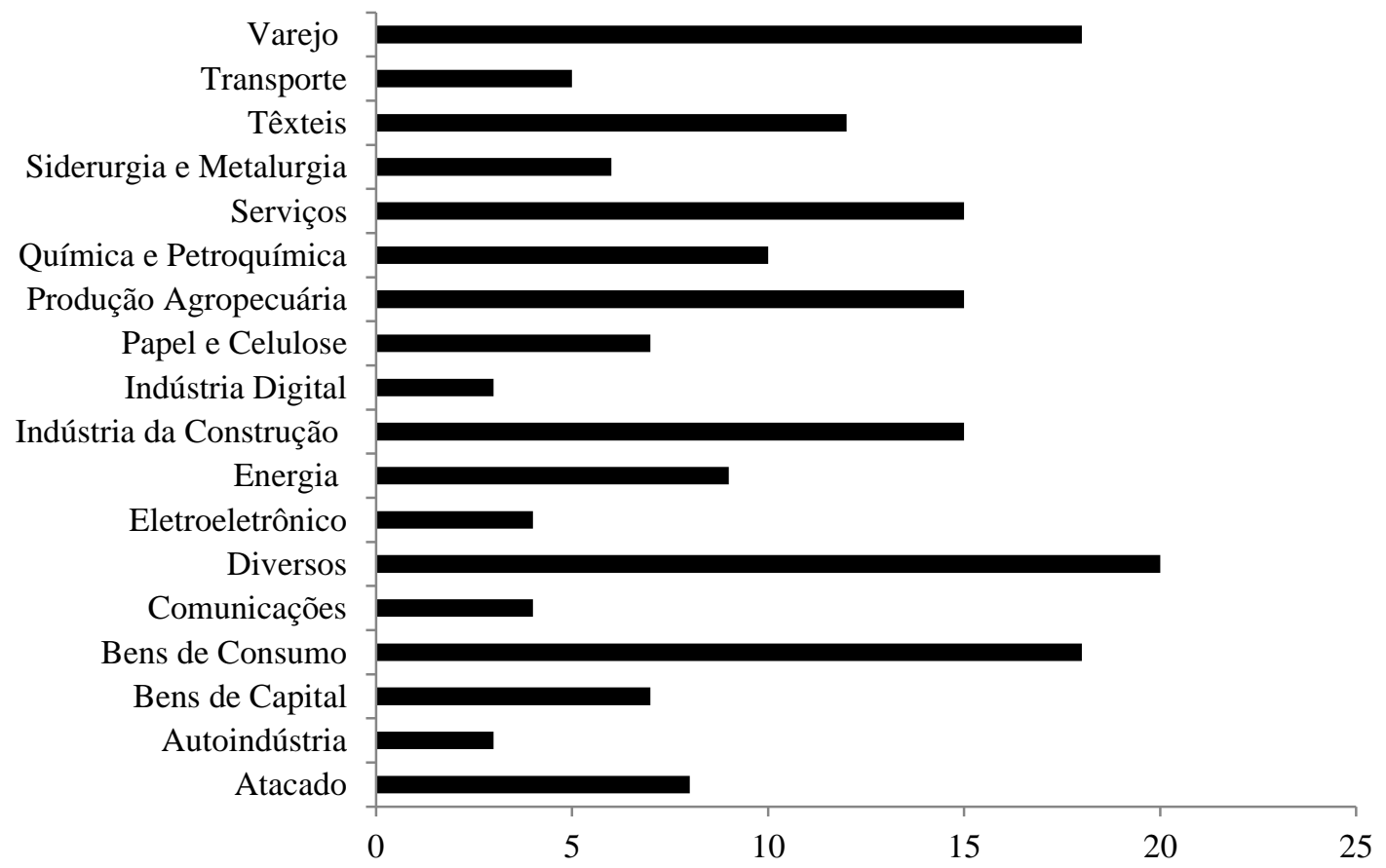

Gráfico 7 - Distribuição da Amostra por Setor da Economia conforme critério da Revista M\&M Exame (2012) em quantidade de empresas

Fonte: elaborado pelo autor 
No tocante aos setores da economia, a mesma fonte segmenta as empresas em 18 áreas de negócio (Ibid., p. 476). A amostra analisada possui a distribuição apresentada no gráfico 7 acima. Para fins de estudo aglutinou-se os setores em cinco grandes áreas setoriais: Serviços (Transporte, Comunicações, Indústria Digital e Serviços), Comércio (Varejo e Atacado), Agronegócios (Produção Agropecuária e Energia ${ }^{122}$ ), Indústria de Bens de Consumo (Consumo, Eletroeletrônicos, Têxteis e Autoindústria) e Indústria de Base ou Pesada (Bens de Capital, Siderurgia e Metalurgia, Química e Petroquímica, Papel e Celulose, Indústria da Construção). As demais empresas diversas foram alocadas aos setores conforme descrição do contexto operacional expressa em seus respectivos balanços.

A seguir é apresentada a amostra por setores da economia, aglutinado por macro setor:

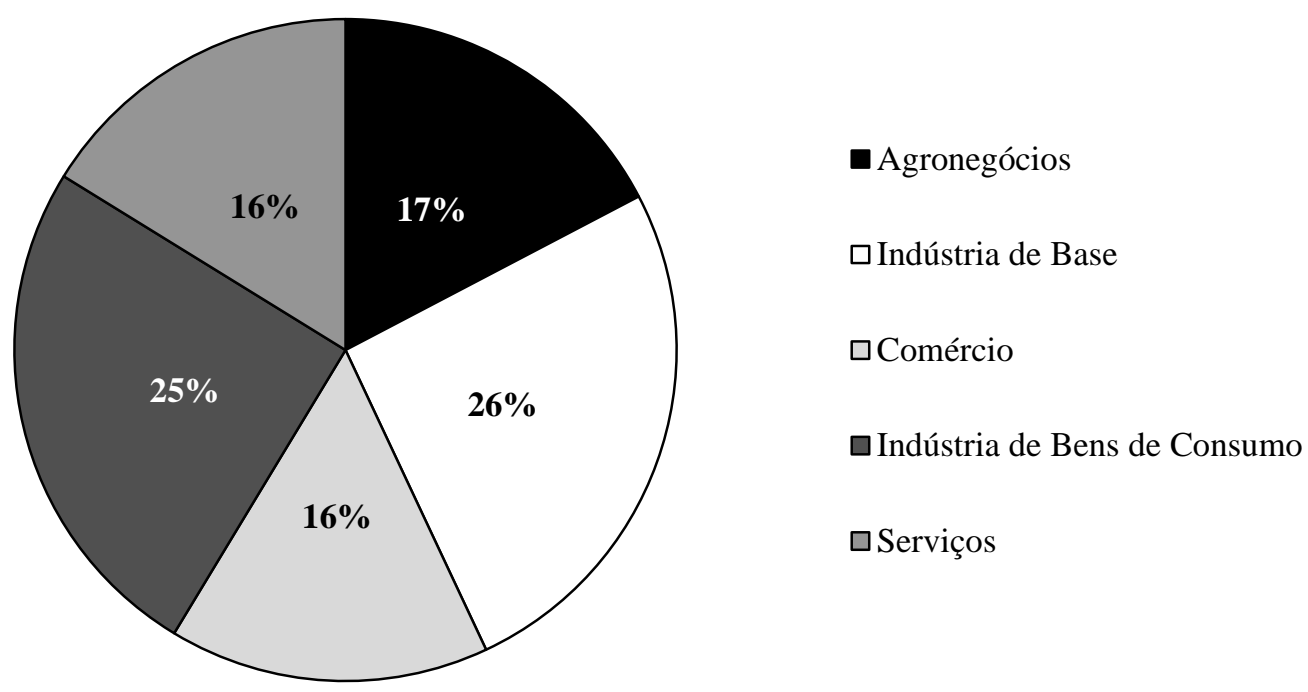

Gráfico 8 - Distribuição da Amostra por Setor da Economia Adaptada (Percentual)

Fonte: elaborado pelo autor

O setor de maior representatividade da amostra foi o segmento de Indústria de Base, com 26\%, seguido do setor de Indústria de Bens de Consumo com 25\%, depois Agronegócios com $17 \%$ e por fim, ambos com $16 \%$, Comércio e Serviços.

As estatísticas descritivas segmentadas por setor de atuação na economia e também por região geográfica da sede, antes de tratamento estatístico se encontram nos apêndices de $\mathrm{C}$ a $\mathrm{H}$, apresentados no final deste trabalho.

${ }^{122}$ Usinas de Cana-de-açúcar. 


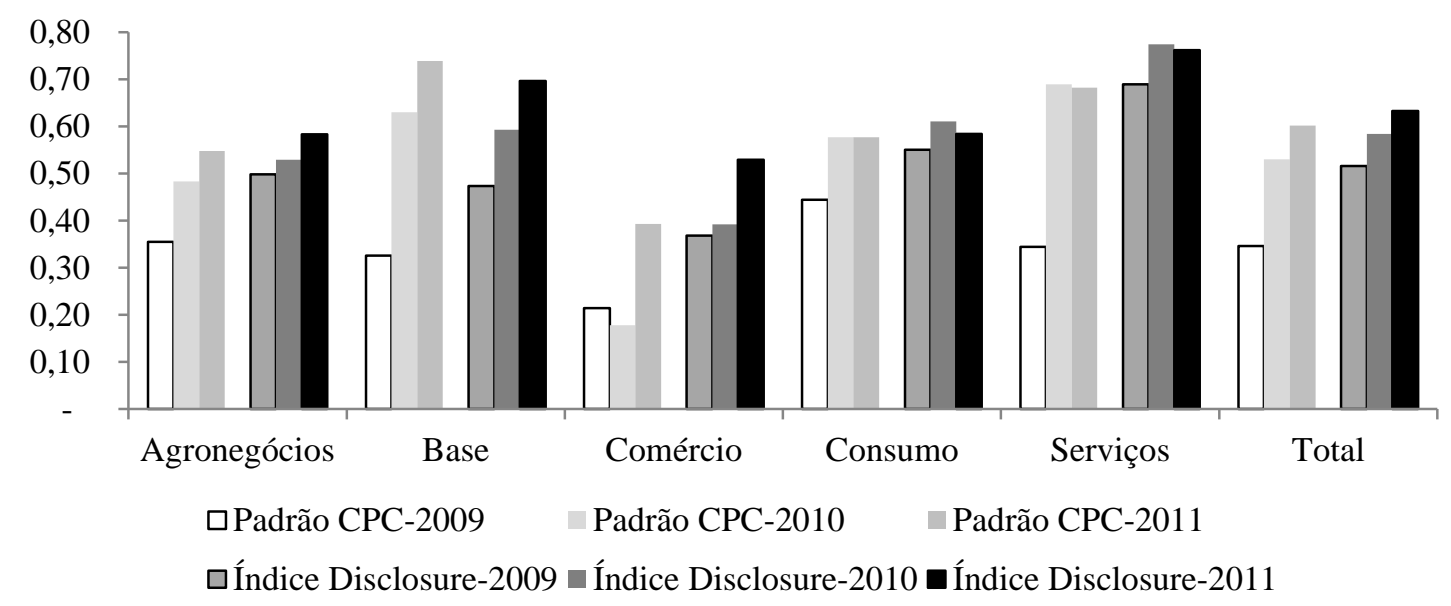

Gráfico 9 - Evolução das Médias dos Índices de Disclosure e Adoção do Padrão CPC (Distribuição Setorial entre 2009-2011)

Fonte: elaborado pelo autor

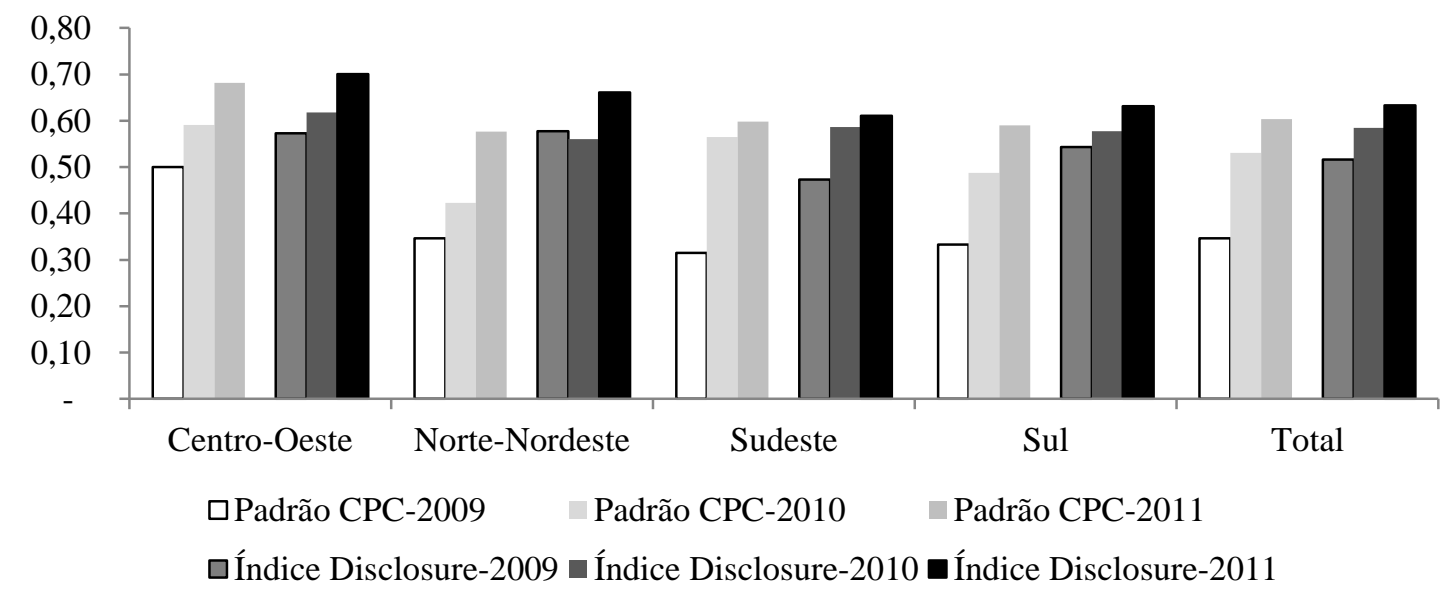

Gráfico 10 - Evolução das Médias dos Índices de Disclosure e Adoção do Padrão CPC (Distribuição Regional entre 2009-2011)

Fonte: elaborado pelo autor

Pela análise gráfica das variáveis de interesse do trabalho, conforme demonstrados nos gráficos 8 e 9, vê-se um predomínio de crescimento na evolução dos índices de disclosure médios e dos níveis de adoção do padrão contábil internacional na amostra estudada, tanto setorialmente como regionalmente. Os testes estatísticos servem para inferir relações mais precisas entre as variáveis. 


\subsubsection{Testes Não Paramétricos}

Para realização dos testes, a fim de analisar o custo de captação de crédito bancário, houve a necessidade de se retirar da amostra algumas observações: (a) as empresas que não possuíam qualquer tipo de empréstimos bancários (total de 43 empresas - 24,0\% da amostra) em algum dos três anos da amostra; (b) as empresas que não apresentaram balanços em algum dos três anos, cujas análises de itens de verificação de evidenciação não puderam ser realizadas $^{123}$ (total de 11 empresas $-6,2 \%$ da amostra), e portanto obtiveram nota zero no índice de disclosure; (c) as empresas que não informaram os valores dos dispêndios com despesas financeiras na demonstração de resultado do exercício (total de 3 empresas $-1,7 \%$ da amostra) e (d) as empresas que em algum dos três anos analisados apresentavam seu passivo a descoberto (total de 7 empresas - 3,9\% da amostra). Logo a amostra ajustada passou a conter o total de 115 empresas, as quais foram submetidas aos testes não paramétricos descritos na seção 3.3.3.1.

A seguir são apresentados os resultados dos testes que contemplam a amostra ajustada por completo. Os testes buscam respostas para as hipóteses I e II, apresentadas na seção 1.1 (p. 12) desta dissertação. Os dados são apresentados por ano de forma empilhada, com os resultados dos agrupamentos de disclosure (acima da média e abaixo da média) e de evidenciação do padrão contábil em 2009 e 2010 (evidenciação do padrão CPC e não evidenciação), em relação a seus efeitos nos índices de custo de captação bancária dos anos seguintes (2010 e 2011), ou seja, observou-se o comportamento das despesas financeiras $\left(I_{1}, I_{2}\right.$ e $\left.I_{3}\right)$ em ano $t+1$, dado um nível de disclosure e um tipo de evidenciação contábil, em ano t.

Logo, foram testadas as hipóteses estatísticas do teste de Mann-Withney para as proxies de despesas financeiras conforme segue:

$$
\begin{aligned}
& \mathrm{H}_{0}: \tilde{\mu}_{A}=\tilde{\mu}_{B} \\
& \mathrm{H}_{1}: \tilde{\mu}_{A}<\tilde{\mu}_{B}
\end{aligned}
$$

sendo que, uma vez não rejeitadas as hipóteses nulas dos testes de Mann-Whitney, indicariam que as hipóteses I e II da pesquisa poderiam ser rejeitadas, e vice-versa. Após análise da amostra

${ }^{123}$ As informações contábeis eram inseridas à base de dados da M\&M Exame com dados do balanço do ano posterior àquele que para o qual não foram enviadas as demonstrações contábeis (2010 e 2011). 
total, são examinadas as diferenças por setor e por região, que permitirá avaliar mais profundamente as relações entre as variáveis.

Tabela 6 - Teste de Mann-Whitney (Amostra Total - 2010 e 2011)

\begin{tabular}{|c|c|c|c|c|c|}
\hline \multicolumn{6}{|c|}{ Total da Amostra $(\mathrm{N}=115)$} \\
\hline 2010 & $\mathrm{~N}$ & Média & Mediana & DP & Mann-Withney \\
\hline \multirow{2}{*}{ Variáveis } & \multicolumn{4}{|c|}{ A - Disclosure acima da Média } & $\mathrm{z}$ calculada \\
\hline & \multicolumn{4}{|c|}{ B - Disclosure abaixo da Média } & Valor P \\
\hline \multirow{2}{*}{$\mathrm{I}_{1}$} & 65 & 0,298 & 0,085 & 0,980 & $-2,488$ \\
\hline & 50 & 0,264 & 0,115 & 0,671 & $0,007 * * *$ \\
\hline \multirow{2}{*}{$\mathrm{I}_{2}$} & 65 & 0,038 & 0,035 & 0,024 & $-1,602$ \\
\hline & 50 & 0,049 & 0,041 & 0,041 & $0,055^{*}$ \\
\hline \multirow{2}{*}{$\mathrm{I}_{3}$} & 65 & 0,087 & 0,044 & 0,108 & $-1,512$ \\
\hline & 50 & 0,144 & 0,062 & 0,254 & $0,066^{*}$ \\
\hline \multirow{2}{*}{ Variáveis } & \multicolumn{4}{|c|}{ A - Evidenciação do Padrão CPC } & z calculada \\
\hline & \multicolumn{4}{|c|}{ B - Não evidenciação } & Valor $\mathrm{P}$ \\
\hline \multirow{2}{*}{$\mathrm{I}_{1}$} & 44 & 0,330 & 0,091 & 0,879 & $-0,662$ \\
\hline & 71 & 0,255 & 0,097 & 0,847 & 0,254 \\
\hline \multirow{2}{*}{$\mathrm{I}_{2}$} & 44 & 0,037 & 0,035 & 0,025 & $-1,295$ \\
\hline & 71 & 0,047 & 0,041 & 0,038 & $0,098^{*}$ \\
\hline \multirow{2}{*}{$\mathrm{I}_{3}$} & 44 & 0,098 & 0,036 & 0,128 & $-1,324$ \\
\hline & 71 & 0,121 & 0,060 & 0,217 & $0,093^{*}$ \\
\hline 2011 & $\mathrm{~N}$ & Média & Mediana & DP & Mann-Withney \\
\hline \multirow{2}{*}{ Variáveis } & \multicolumn{4}{|c|}{ A - Disclosure acima da Média } & $\mathrm{z}$ calculada \\
\hline & \multicolumn{4}{|c|}{ B - Disclosure abaixo da Média } & Valor P \\
\hline \multirow{2}{*}{$\mathrm{I}_{1}$} & 62 & 0,330 & 0,104 & 0,812 & $-0,763$ \\
\hline & 53 & 0,156 & 0,111 & 0,147 & 0,223 \\
\hline \multirow{2}{*}{$\mathrm{I}_{2}$} & 62 & 0,047 & 0,045 & 0,030 & $-1,122$ \\
\hline & 53 & 0,058 & 0,049 & 0,046 & 0,131 \\
\hline \multirow{2}{*}{$\mathrm{I}_{3}$} & 62 & 0,139 & 0,063 & 0,238 & $-0,572$ \\
\hline & 53 & 0,174 & 0,053 & 0,291 & 0,284 \\
\hline \multirow{2}{*}{ Variáveis } & \multicolumn{4}{|c|}{ A - Evidenciação do Padrão CPC } & $\mathrm{z}$ calculada \\
\hline & \multicolumn{4}{|c|}{ B - Não evidenciação } & Valor P \\
\hline \multirow{2}{*}{$\mathrm{I}_{1}$} & 65 & 0,318 & 0,099 & 0,794 & $-0,999$ \\
\hline & 50 & 0,161 & 0,112 & 0,152 & 0,159 \\
\hline \multirow{2}{*}{$\mathrm{I}_{2}$} & 65 & 0,046 & 0,043 & 0,028 & $-0,953$ \\
\hline & 50 & 0,059 & 0,050 & 0,048 & 0,170 \\
\hline \multirow{2}{*}{$\mathrm{I}_{3}$} & 65 & 0,134 & 0,058 & 0,229 & $-0,626$ \\
\hline & 50 & 0,184 & 0,061 & 0,302 & 0,266 \\
\hline \multicolumn{6}{|c|}{ *: valor-p é significativo a um nível de significância de $10 \%$} \\
\hline$* *:$ & & . & a um nív & signific & ncia de $5 \%$ \\
\hline
\end{tabular}

Para o nível de disclosure a hipótese nula é rejeitada nos três índices de despesas financeiras em 2010. É dizer, pode-se inferir que o custo de crédito bancário é menor para demonstrações contábeis divulgadas com disclosure acima da média. O mesmo ocorre para dois dos três índices $\left(\mathrm{I}_{2}\right.$ e $\left.\mathrm{I}_{3}\right)$, ao analisar a evidenciação do padrão contábil baseado no CPC. 
Entretanto, os resultados não se repetiram para o ano seguinte, em que não se rejeita a hipótese nula para ambas as categorias, ou seja, não é possível dizer nem que os custos são menores quando há melhor disclosure, nem quando há adoção do padrão contábil com base no CPC em 2011. Não houve consistência entre os resultados dos dois anos.

Seguem abaixo as análises por segmento da economia, para tentar identificar diferenças setoriais, entre os custos de captação por categoria de divulgação contábil (disclosure e evidenciação do padrão CPC).

Tabela 7 - Teste de Mann-Whitney (Agronegócios - 2010 e 2011)

\begin{tabular}{|c|c|c|c|c|c|}
\hline \multicolumn{6}{|c|}{ Agronegócios $(\mathrm{N}=19)$} \\
\hline 2010 & $\mathrm{~N}$ & Média & Mediana & DP & Mann-Withney \\
\hline \multirow{2}{*}{ Variáveis } & \multicolumn{4}{|c|}{ A - Disclosure acima da Média } & $\mathrm{z}$ calculada \\
\hline & \multicolumn{4}{|c|}{ B - Disclosure abaixo da Média } & Valor P \\
\hline \multirow{2}{*}{$\mathrm{I}_{1}$} & 11 & 0,111 & 0,077 & 0,120 & $-0,248$ \\
\hline & 8 & 0,102 & 0,088 & 0,078 & 0,420 \\
\hline \multirow{2}{*}{$\mathrm{I}_{2}$} & 11 & 0,034 & 0,035 & 0,015 & $-0,330$ \\
\hline & 8 & 0,046 & 0,043 & 0,038 & 0,389 \\
\hline \multirow{2}{*}{$\mathrm{I}_{3}$} & 11 & 0,115 & 0,034 & 0,174 & $-0,743$ \\
\hline & 8 & 0,267 & 0,092 & 0,547 & 0,246 \\
\hline \multirow{2}{*}{ Variáveis } & \multicolumn{4}{|c|}{ A - Evidenciação do Padrão CPC } & $\mathrm{z}$ calculada \\
\hline & \multicolumn{4}{|c|}{ B - Não evidenciação } & Valor P \\
\hline \multirow{2}{*}{$\mathrm{I}_{1}$} & 8 & 0,106 & 0,078 & 0,082 & $-0,083$ \\
\hline & 11 & 0,109 & 0,071 & 0,118 & 0,484 \\
\hline \multirow{2}{*}{$\mathrm{I}_{2}$} & 8 & 0,033 & 0,035 & 0,014 & $-0,248$ \\
\hline & 11 & 0,044 & 0,041 & 0,033 & 0,420 \\
\hline \multirow{2}{*}{$\mathrm{I}_{3}$} & 8 & 0,139 & 0,057 & 0,199 & $-0,248$ \\
\hline & 11 & 0,208 & 0,045 & 0,470 & 0,420 \\
\hline 2011 & $\mathrm{~N}$ & Média & Mediana & DP & Mann-Withney \\
\hline \multirow{2}{*}{ Variáveis } & \multicolumn{4}{|c|}{ A - Disclosure acima da Média } & $\mathrm{z}$ calculada \\
\hline & & Disclosut & $e$ abaixo da & lédia & Valor P \\
\hline \multirow{2}{*}{$\mathrm{I}_{1}$} & 11 & 0,104 & 0,049 & 0,101 & $-0,248$ \\
\hline & 8 & 0,083 & 0,074 & 0,048 & 0,420 \\
\hline \multirow{2}{*}{$\mathrm{I}_{2}$} & 11 & 0,041 & 0,040 & 0,019 & $-0,165$ \\
\hline & 8 & 0,043 & 0,043 & 0,028 & 0,452 \\
\hline \multirow{2}{*}{$\mathrm{I}_{3}$} & 11 & 0,226 & 0,064 & 0,461 & $-0,165$ \\
\hline & 8 & 0,247 & 0,048 & 0,519 & 0,452 \\
\hline \multirow{2}{*}{ Variáveis } & \multicolumn{4}{|c|}{ A - Evidenciação do Padrão CPC } & $\mathrm{z}$ calculada \\
\hline & \multicolumn{4}{|c|}{ B - Não evidenciação } & Valor P \\
\hline \multirow{2}{*}{$\mathrm{I}_{1}$} & 10 & 0,099 & 0,067 & 0,087 & 0,000 \\
\hline & 9 & 0,090 & 0,079 & 0,082 & 0,500 \\
\hline \multirow{2}{*}{$\mathrm{I}_{2}$} & 10 & 0,047 & 0,038 & 0,022 & $-0,653$ \\
\hline & 9 & 0,036 & 0,040 & 0,023 & 0,274 \\
\hline \multirow{2}{*}{$\mathrm{I}_{3}$} & 10 & 0,257 & 0,070 & 0,477 & $-0,898$ \\
\hline & 9 & 0,210 & 0,043 & 0,494 & 0,200 \\
\hline
\end{tabular}

Com os resultados do setor de agronegócios, não foi possível rejeitar a hipótese nula, ou seja, não é possível dizer que os custos são menores nem quando há melhor disclosure, nem 
quando há adoção do padrão contábil com base no CPC, tanto para o ano de 2010, como para o ano de 2011.

Tabela 8 - Teste de Mann-Whitney (Indústria de Base - 2010 e 2011)

\begin{tabular}{|c|c|c|c|c|c|}
\hline \multicolumn{6}{|c|}{ Indústria de Base $(\mathrm{N}=26)$} \\
\hline 2010 & $\mathrm{~N}$ & Média & Mediana & DP & Mann-Withney \\
\hline \multirow{2}{*}{ Variáveis } & \multicolumn{4}{|c|}{ A - Disclosure acima da Média } & z calculada \\
\hline & \multicolumn{4}{|c|}{ B - Disclosure abaixo da Média } & Valor P \\
\hline \multirow{2}{*}{$\mathrm{I}_{1}$} & 14 & 0,090 & 0,074 & 0,050 & $-1,492$ \\
\hline & 12 & 0,133 & 0,116 & 0,083 & $0,073^{*}$ \\
\hline \multirow{2}{*}{$\mathrm{I}_{2}$} & 14 & 0,032 & 0,026 & 0,021 & $-1,646$ \\
\hline & 12 & 0,064 & 0,042 & 0,070 & $0,053 *$ \\
\hline \multirow{2}{*}{$\mathrm{I}_{3}$} & 14 & 0,064 & 0,034 & 0,075 & $-1,286$ \\
\hline & 12 & 0,134 & 0,069 & 0,182 & 0,106 \\
\hline \multirow{2}{*}{ Variáveis } & \multicolumn{4}{|c|}{ A - Evidenciação do Padrão CPC } & z calculada \\
\hline & \multicolumn{4}{|c|}{ B - Não evidenciação } & Valor P \\
\hline \multirow{2}{*}{$\mathrm{I}_{1}$} & 9 & 0,099 & 0,079 & 0,061 & $-0,458$ \\
\hline & 17 & 0,116 & 0,097 & 0,074 & 0,336 \\
\hline \multirow{2}{*}{$\mathrm{I}_{2}$} & 9 & 0,033 & 0,025 & 0,026 & $-1,159$ \\
\hline & 17 & 0,054 & 0,038 & 0,060 & 0,132 \\
\hline \multirow{2}{*}{$\mathrm{I}_{3}$} & 9 & 0,072 & 0,026 & 0,091 & $-0,889$ \\
\hline & 17 & 0,109 & 0,066 & 0,157 & 0,198 \\
\hline 2011 & $\mathrm{~N}$ & Média & Mediana & DP & Mann-Withney \\
\hline \multirow{2}{*}{ Variáveis } & \multicolumn{4}{|c|}{ A - Disclosure acima da Média } & $\mathrm{z}$ calculada \\
\hline & & - Disclosu & re abaixo $\mathrm{d}$ & Média & Valor P \\
\hline \multirow{2}{*}{$\mathrm{I}_{1}$} & 14 & 0,106 & 0,083 & 0,072 & $-1,132$ \\
\hline & 12 & 0,135 & 0,120 & 0,074 & 0,137 \\
\hline \multirow{2}{*}{$\mathrm{I}_{2}$} & 14 & 0,041 & 0,048 & 0,030 & $-0,874$ \\
\hline & 12 & 0,069 & 0,044 & 0,064 & 0,202 \\
\hline \multirow{2}{*}{$\mathrm{I}_{3}$} & 14 & 0,079 & 0,052 & 0,094 & $-1,337$ \\
\hline & 12 & 0,256 & 0,072 & 0,389 & $0,097 *$ \\
\hline \multirow{2}{*}{ Variáveis } & \multicolumn{4}{|c|}{ A - Evidenciação do Padrão CPC } & $\mathrm{z}$ calculada \\
\hline & \multicolumn{4}{|c|}{ B - Não evidenciação } & Valor P \\
\hline \multirow{2}{*}{$\mathrm{I}_{1}$} & 17 & 0,101 & 0,078 & 0,066 & $-1,806$ \\
\hline & 9 & 0,153 & 0,147 & 0,076 & $0,038^{* *}$ \\
\hline \multirow{2}{*}{$\mathrm{I}_{2}$} & 17 & 0,039 & 0,038 & 0,027 & $-1,482$ \\
\hline & 9 & 0,081 & 0,050 & 0,071 & $0,074 *$ \\
\hline \multirow{2}{*}{$\mathrm{I}_{3}$} & 17 & 0,080 & 0,054 & 0,088 & $-1,482$ \\
\hline & 9 & 0,314 & 0,085 & 0,438 & $0,074 *$ \\
\hline
\end{tabular}

Para o setor de indústria de base, no teste do nível de disclosure a hipótese nula é rejeitada em dois nos três índices de despesas financeiras em $2010\left(\mathrm{I}_{1}\right.$ e $\left.\mathrm{I}_{2}\right)$. É dizer, pode-se inferir que o custo de crédito bancário é menor para demonstrações contábeis divulgadas com disclosure acima da média. Em 2011, o teste rejeita a hipótese nula para o índice $\mathrm{I}_{3}$. 
Ao analisar a evidenciação do padrão contábil baseado no CPC, somente no segundo ano analisado os resultados rejeitaram a hipótese nula para todos os índices calculados.

Este foi o setor com maior grau de rejeição das hipóteses nulas, em ambas as hipóteses, indicando maior possibilidade de não rejeição das hipóteses I e II para o setor.

Tabela 9 - Teste de Mann-Whitney (Serviços - 2010 e 2011)

\begin{tabular}{|c|c|c|c|c|c|}
\hline \multicolumn{6}{|c|}{ Serviços $(\mathrm{N}=18)$} \\
\hline 2010 & $\mathrm{~N}$ & Média & Mediana & DP & Mann-Withney \\
\hline \multirow{2}{*}{ Variáveis } & \multicolumn{4}{|c|}{ A - Disclosure acima da Média } & z calculada \\
\hline & \multicolumn{4}{|c|}{ B - Disclosure abaixo da Média } & Valor P \\
\hline \multirow{2}{*}{$\mathrm{I}_{1}$} & 16 & 0,900 & 0,121 & 1,888 & $-0,421$ \\
\hline & 2 & 0,207 & 0,207 & 0,157 & 0,366 \\
\hline \multirow{2}{*}{$\mathrm{I}_{2}$} & 16 & 0,037 & 0,037 & 0,026 & $-0,983$ \\
\hline & 2 & 0,048 & 0,048 & 0,013 & 0,196 \\
\hline \multirow{2}{*}{$\mathrm{I}_{3}$} & 16 & 0,060 & 0,041 & 0,075 & $-1,124$ \\
\hline & 2 & 0,128 & 0,128 & 0,120 & 0,164 \\
\hline \multirow{2}{*}{ Variáveis } & \multicolumn{4}{|c|}{ A - Evidenciação do Padrão CPC } & $\mathrm{z}$ calculada \\
\hline & \multicolumn{4}{|c|}{ B - Não evidenciação } & Valor P \\
\hline \multirow{2}{*}{$\mathrm{I}_{1}$} & 9 & 0,684 & 0,139 & 1,252 & $-0,662$ \\
\hline & 9 & 0,962 & 0,102 & 2,276 & 0,273 \\
\hline \multirow{2}{*}{$\mathrm{I}_{2}$} & 9 & 0,023 & 0,014 & 0,015 & $-2,517$ \\
\hline & 9 & 0,053 & 0,045 & 0,025 & $0,005 * * *$ \\
\hline \multirow{2}{*}{$\mathrm{I}_{3}$} & 9 & 0,048 & 0,014 & 0,093 & $-2,517$ \\
\hline & 9 & 0,088 & 0,060 & 0,061 & $0,005 * * *$ \\
\hline 2011 & $\mathrm{~N}$ & Média & Mediana & DP & Mann-Withney \\
\hline \multirow{2}{*}{ Variáveis } & \multicolumn{4}{|c|}{ A - Disclosure acima da Média } & z calculada \\
\hline & \multicolumn{4}{|c|}{ B - Disclosure abaixo da Média } & Valor P \\
\hline \multirow{2}{*}{$\mathrm{I}_{1}$} & 14 & 0,976 & 0,113 & 1,549 & $-0,425$ \\
\hline & 4 & 0,194 & 0,176 & 0,069 & 0,361 \\
\hline \multirow{2}{*}{$\mathrm{I}_{2}$} & 14 & 0,041 & 0,041 & 0,021 & $-2,336$ \\
\hline & 4 & 0,077 & 0,077 & 0,016 & $0,009 * * *$ \\
\hline \multirow{2}{*}{$\mathrm{I}_{3}$} & 14 & 0,081 & 0,066 & 0,082 & $-0,212$ \\
\hline & 4 & 0,107 & 0,061 & 0,102 & 0,439 \\
\hline \multirow{2}{*}{ Variáveis } & \multicolumn{4}{|c|}{ A - Evidenciação do Padrão CPC } & $\mathrm{z}$ calculada \\
\hline & \multicolumn{4}{|c|}{ B - Não evidenciação } & Valor P \\
\hline \multirow{2}{*}{$\mathrm{I}_{1}$} & 14 & 0,982 & 0,152 & 1,546 & 0,000 \\
\hline & 4 & 0,175 & 0,150 & 0,082 & 0,500 \\
\hline \multirow{2}{*}{$\mathrm{I}_{2}$} & 14 & 0,045 & 0,047 & 0,026 & $-1,168$ \\
\hline & 4 & 0,063 & 0,064 & 0,019 & 0,139 \\
\hline \multirow{2}{*}{$\mathrm{I}_{3}$} & 14 & 0,081 & 0,065 & 0,082 & $-0,319$ \\
\hline & 4 & 0,107 & 0,062 & 0,102 & 0,399 \\
\hline \multicolumn{6}{|c|}{ *: valor-p é significativo a um nível de significância de $10 \%$} \\
\hline
\end{tabular}


Os valores de probabilidade das estatísticas calculadas nos permite rejeitar a hipótese nula para os índices $\mathrm{I}_{2}$ e $\mathrm{I}_{3}$, no ano de 2010, para o setor de serviços, com um nível de significância de $1 \%$, somente para a variável evidenciação do padrão contábil CPC. No entanto, os resultados não se repetiram para o ano seguinte para este setor.

Para a categoria nível de disclosure, somente se rejeita a hipótese nula para o índice $\mathrm{I}_{2}$, no ano de 2011.

Tabela 10 - Teste de Mann-Whitney (Indústria de Bens de Consumo - 2010 e 2011)

\begin{tabular}{|c|c|c|c|c|c|}
\hline \multicolumn{6}{|c|}{ Indústria de Bens de Consumo $(\mathrm{N}=35)$} \\
\hline 2010 & $\mathrm{~N}$ & Média & Mediana & DP & Mann-Withney \\
\hline \multirow{2}{*}{ Variáveis } & \multicolumn{4}{|c|}{ A - Disclosure acima da Média } & z calculada \\
\hline & \multicolumn{4}{|c|}{ B - Disclosure abaixo da Média } & Valor P \\
\hline \multirow{2}{*}{$\mathrm{I}_{1}$} & 18 & 0,112 & 0,092 & 0,107 & $-1,485$ \\
\hline & 17 & 0,232 & 0,041 & 0,131 & $0,072 *$ \\
\hline \multirow{2}{*}{$\mathrm{I}_{2}$} & 18 & 0,050 & 0,051 & 0,025 & $-0,726$ \\
\hline & 17 & 0,042 & 0,041 & 0,019 & 0,241 \\
\hline \multirow{2}{*}{$\mathrm{I}_{3}$} & 18 & 0,117 & 0,072 & 0,108 & $-0,594$ \\
\hline & 17 & 0,120 & 0,046 & 0,134 & 0,284 \\
\hline \multirow{2}{*}{ Variáveis } & \multicolumn{4}{|c|}{ A - Evidenciação do Padrão CPC } & $\mathrm{z}$ calculada \\
\hline & \multicolumn{4}{|c|}{ B - Não evidenciação } & Valor P \\
\hline \multirow{2}{*}{$\mathrm{I}_{1}$} & 14 & 0,132 & 0,094 & 0,120 & $-0,067$ \\
\hline & 21 & 0,203 & 0,096 & 0,400 & 0,480 \\
\hline \multirow{2}{*}{$\mathrm{I}_{2}$} & 14 & 0,053 & 0,054 & 0,027 & $-1,381$ \\
\hline & 21 & 0,041 & 0,039 & 0,017 & $0,088^{*}$ \\
\hline \multirow{2}{*}{$\mathrm{I}_{3}$} & 14 & 0,128 & 0,066 & 0,126 & $-0,101$ \\
\hline & 21 & 0,113 & 0,058 & 0,117 & 0,467 \\
\hline 2011 & $\mathrm{~N}$ & Média & Mediana & DP & Mann-Withney \\
\hline \multirow{2}{*}{ Variáveis } & \multicolumn{4}{|c|}{ A - Disclosure acima da Média } & $\mathrm{z}$ calculada \\
\hline & $\mathrm{B}-\mathrm{L}$ & sclosure & abaixo da $\mathrm{I}$ & Média & Valor P \\
\hline \multirow{2}{*}{$\mathrm{I}_{1}$} & 19 & 0,190 & 0,120 & 0,252 & $-0,265$ \\
\hline & 16 & 0,166 & 0,106 & 0,162 & 0,403 \\
\hline \multirow{2}{*}{$\mathrm{I}_{2}$} & 19 & 0,062 & 0,051 & 0,038 & $-0,166$ \\
\hline & 16 & 0,064 & 0,061 & 0,047 & 0,442 \\
\hline \multirow{2}{*}{$\mathrm{I}_{3}$} & 19 & 0,161 & 0,065 & 0,188 & $-0,728$ \\
\hline & 16 & 0,180 & 0,087 & 0,172 & 0,241 \\
\hline \multirow{2}{*}{ Variáveis } & \multicolumn{4}{|c|}{ A - Evidenciação do Padrão CPC } & $\mathrm{z}$ calculada \\
\hline & \multicolumn{4}{|c|}{ B - Não evidenciação } & Valor P \\
\hline \multirow[b]{2}{*}{$I_{1}$} & 19 & 0,186 & 0,102 & 0,253 & $-0,728$ \\
\hline & 16 & 0,171 & 0,116 & 0,161 & 0,241 \\
\hline \multirow{2}{*}{$\mathrm{I}_{2}$} & 19 & 0,058 & 0,051 & 0,033 & $-0,497$ \\
\hline & 16 & 0,069 & 0,061 & 0,050 & 0,318 \\
\hline \multirow{2}{*}{$\mathrm{I}_{3}$} & 19 & 0,145 & 0,059 & 0,174 & $-1,589$ \\
\hline & 16 & 0,199 & 0,087 & 0,185 & $0,059 *$ \\
\hline
\end{tabular}


No setor de indústria de bens de consumo, rejeita-se a hipótese nula para o índice $\mathrm{I}_{2}$, em 2010, em nível de disclosure, para evidenciação da adoção do padrão contábil internacional com base no CPC, não se rejeita a hipótese nula nem em 2010, tão pouco em 2011.

Tabela 11 - Teste de Mann-Whitney (Comércio - 2010 e 2011)

\begin{tabular}{|c|c|c|c|c|c|}
\hline \multicolumn{6}{|c|}{ Comércio $(\mathrm{N}=13)$} \\
\hline 2010 & $\mathrm{~N}$ & Média & Mediana & DP & Mann-Withney \\
\hline \multirow{2}{*}{ Variáveis } & \multicolumn{4}{|c|}{ A - Disclosure acima da Média } & z calculada \\
\hline & \multicolumn{4}{|c|}{ B - Disclosure abaixo da Média } & Valor P \\
\hline \multirow{2}{*}{$\mathrm{I} 1$} & 6 & 0,090 & 0,100 & 0,038 & $-1,857$ \\
\hline & 7 & 0,164 & 0,143 & 0,080 & $0,037 * *$ \\
\hline \multirow{2}{*}{$\mathrm{I} 2$} & 6 & 0,032 & 0,032 & 0,025 & $-0,429$ \\
\hline & 7 & 0,036 & 0,032 & 0,017 & 0,365 \\
\hline \multirow{2}{*}{$\mathrm{I} 3$} & 6 & 0,073 & 0,018 & 0,096 & $-0,286$ \\
\hline & 7 & 0,040 & 0,031 & 0,029 & 0,418 \\
\hline \multirow{2}{*}{ Variáveis } & \multicolumn{4}{|c|}{ A - Evidenciação do Padrão CPC } & $\mathrm{z}$ calculada \\
\hline & \multicolumn{4}{|c|}{ B - Não evidenciação } & Valor P \\
\hline \multirow{2}{*}{ I1 } & 3 & 0,094 & 0,108 & 0,053 & $-0,676$ \\
\hline & 10 & 0,140 & 0,106 & 0,087 & 0,287 \\
\hline \multirow{2}{*}{$\mathrm{I} 2$} & 3 & 0,038 & 0,048 & 0,030 & $-0,169$ \\
\hline & 10 & 0,033 & 0,029 & 0,019 & 0,469 \\
\hline \multirow{2}{*}{$\mathrm{I} 3$} & 3 & 0,083 & 0,022 & 0,123 & 0,000 \\
\hline & 10 & 0,047 & 0,024 & 0,049 & 0,500 \\
\hline 2011 & $\mathrm{~N}$ & Média & Mediana & DP & Mann-Withney \\
\hline \multirow{2}{*}{ Variáveis } & \multicolumn{4}{|c|}{ A - Disclosure acima da Média } & z calculada \\
\hline & \multicolumn{4}{|c|}{ B - Disclosure abaixo da Média } & Valor P \\
\hline \multirow{2}{*}{$\mathrm{I} 1$} & 2 & 0,203 & 0,203 & 0,116 & $-0,987$ \\
\hline & 11 & 0,210 & 0,108 & 0,233 & 0,205 \\
\hline \multirow{2}{*}{$\mathrm{I} 2$} & 2 & 0,030 & 0,030 & 0,012 & $-0,395$ \\
\hline & 11 & 0,035 & 0,030 & 0,029 & 0,385 \\
\hline \multirow{2}{*}{$\mathrm{I} 3$} & 2 & 0,076 & 0,076 & 0,030 & $-1,382$ \\
\hline & 11 & 0,046 & 0,029 & 0,060 & 0,116 \\
\hline \multirow{2}{*}{ Variáveis } & \multicolumn{4}{|c|}{ A - Evidenciação do Padrão CPC } & $\mathrm{z}$ calculada \\
\hline & \multicolumn{4}{|c|}{ B - Não evidenciação } & Valor P \\
\hline \multirow{2}{*}{$\mathrm{I} 1$} & 3 & 0,197 & 0,186 & 0,083 & $-1,183$ \\
\hline & 10 & 0,212 & 0,108 & 0,246 & 0,144 \\
\hline \multirow{2}{*}{$\mathrm{I} 2$} & 3 & 0,052 & 0,039 & 0,038 & $-1,352$ \\
\hline & 10 & 0,029 & 0,024 & 0,022 & $0,088^{*}$ \\
\hline \multirow{2}{*}{$\mathrm{I} 3$} & 3 & 0,075 & 0,071 & 0,021 & $-1,690$ \\
\hline & 10 & 0,043 & 0,021 & 0,062 & $0,046 * *$ \\
\hline
\end{tabular}

*: valor-p é significativo a um nível de significância de $10 \%$

**: valor-p é significativo a um nível de significância de 5\%

***: valor-p é significativo a um nível de significância de $1 \%$

No setor comercial, apenas houve significância na variável $\mathrm{I}_{1}$, no teste de nível de disclosure, em 2010, a um nível de confiança de 5\%, que não se repetiu para o ano seguinte. Para os demais testes em nível de disclosure, não se rejeita a hipótese nula. 
Para a categoria nível de evidenciação do padrão contábil, se rejeita a hipótese nula para os índices $\mathrm{I}_{2}$ e $\mathrm{I}_{3}$, mas somente no ano de 2011.

Quadro 5 - Resumo dos Resultados dos Testes Não Paramétricos por Setor de Atividade

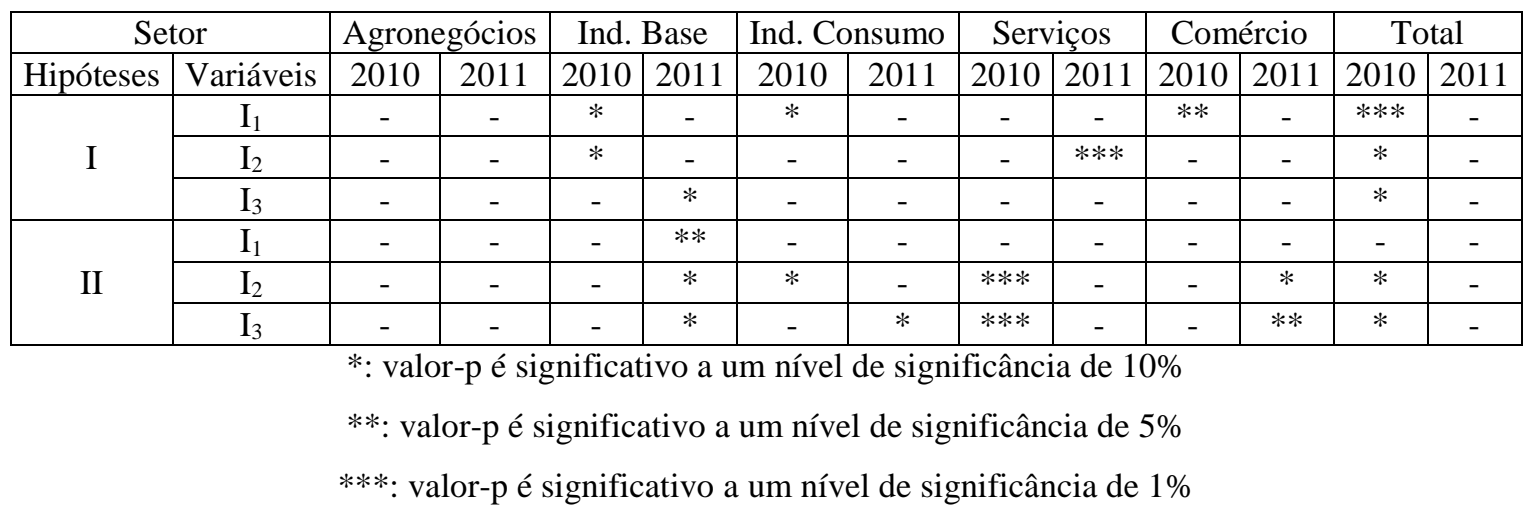

Dos 60 testes não paramétricos realizados nos setores da economia, apenas no setor de agronegócios, não houve significância em nenhum dos testes, nos demais, em algum dos anos estudados, houve pelo menos um índice relacionado a despesas financeiras com significância, tanto para a hipótese I, como para a hipótese II

O total de 15 testes apresentaram diferenças estatisticamente significativas entre os grupos de análise. Há de se fazer uma consideração especial ao setor de indústria de base, que para a hipótese I, encontrou diferenciação entre as médias para os índices $I_{1}$ e $I_{2}$ em 2010 e $I_{3}$ em 2011, e para a hipótese II, houve diferenciação para todos os índices em 2011.

Os outros três segmentos da economia (Comércio, Serviços e Indústria de bens de consumo) tiveram 3 índices cada, diferentes entre os grupos, com médias estatisticamente significativas, no entanto, eles não se repetiram entre os anos, ou seja, não houve consistência no tempo.

Mesmo assim, não são desprezíveis os achados. Eles podem indicar que já começa a se encontrar uma diferenciação entre grupos com diferentes níveis de divulgação contábil, se observarmos certos setores em determinados períodos. 
Seguem abaixo as análises realizadas por região do Brasil, na tentativa de identificar possíveis diferenças regionais entre os custos de captação bancária por categoria de divulgação contábil.

Tabela 12 - Teste de Mann-Whitney (Centro-Oeste - 2010 e 2011)

\begin{tabular}{|c|c|c|c|c|c|}
\hline \multicolumn{6}{|c|}{ Centro-Oeste $(\mathrm{N}=16)$} \\
\hline 2010 & $\mathrm{~N}$ & Média & Mediana & DP & Mann-Withney \\
\hline \multirow{2}{*}{ Variáveis } & \multicolumn{4}{|c|}{ A - Disclosure acima da Média } & $\mathrm{z}$ calculada \\
\hline & \multicolumn{4}{|c|}{ B - Disclosure abaixo da Média } & Valor P \\
\hline \multirow{2}{*}{$\mathrm{I}_{1}$} & 10 & 0,678 & 0,166 & 1,180 & $-0,542$ \\
\hline & 6 & 0,141 & 0,111 & 0,109 & 0,318 \\
\hline \multirow{2}{*}{$\mathrm{I}_{2}$} & 10 & 0,037 & 0,029 & 0,032 & $-0,759$ \\
\hline & 6 & 0,040 & 0,039 & 0,020 & 0,246 \\
\hline \multirow{2}{*}{$\mathrm{I}_{3}$} & 10 & 0,064 & 0,031 & 0,082 & 0,000 \\
\hline & 6 & 0,050 & 0,043 & 0,035 & 0,500 \\
\hline \multirow{2}{*}{ Variáveis } & \multicolumn{4}{|c|}{ A - Evidenciação do Padrão CPC } & $\mathrm{z}$ calculada \\
\hline & \multicolumn{4}{|c|}{ B - Não evidenciação } & Valor P \\
\hline \multirow{2}{*}{$\mathrm{I}_{1}$} & 7 & 0,863 & 0,230 & 1,386 & $-1,111$ \\
\hline & 9 & 0,176 & 0,106 & 0,190 & 0,151 \\
\hline \multirow{2}{*}{$\mathrm{I}_{2}$} & 7 & 0,024 & 0,016 & 0,016 & $-2,064$ \\
\hline & 9 & 0,049 & 0,045 & 0,030 & $0,021 * *$ \\
\hline \multirow{2}{*}{$\mathrm{I}_{3}$} & 7 & 0,027 & 0,010 & 0,033 & $-1,641$ \\
\hline & 9 & 0,083 & 0,047 & 0,078 & $0,057 *$ \\
\hline 2011 & $\mathrm{~N}$ & Média & Mediana & DP & Mann-Withney \\
\hline \multirow{2}{*}{ Variáveis } & \multicolumn{4}{|c|}{ A - Disclosure acima da Média } & $\mathrm{z}$ calculada \\
\hline & \multicolumn{4}{|c|}{ B - Disclosure abaixo da Média } & Valor P \\
\hline \multirow{2}{*}{$\mathrm{I}_{1}$} & 9 & 1,439 & 0,285 & 1,793 & $-1,852$ \\
\hline & 7 & 0,110 & 0,093 & 0,095 & $0,036 * *$ \\
\hline \multirow{2}{*}{$\mathrm{I}_{2}$} & 9 & 0,034 & 0,022 & 0,025 & $-0,688$ \\
\hline & 7 & 0,044 & 0,032 & 0,029 & 0,268 \\
\hline \multirow{2}{*}{$\mathrm{I}_{3}$} & 9 & 0,038 & 0,037 & 0,031 & $-0,582$ \\
\hline & 7 & 0,086 & 0,048 & 0,119 & 0,303 \\
\hline \multirow{2}{*}{ Variáveis } & \multicolumn{4}{|c|}{ A - Evidenciação do Padrão CPC } & $\mathrm{z}$ calculada \\
\hline & \multicolumn{4}{|c|}{ B - Não evidenciação } & Valor P \\
\hline \multirow{2}{*}{$\mathrm{I}_{1}$} & 10 & 1,302 & 0,229 & 1,745 & $-1,519$ \\
\hline & 6 & 0,117 & 0,100 & 0,102 & $0,074 *$ \\
\hline \multirow{2}{*}{$\mathrm{I}_{2}$} & 10 & 0,034 & 0,026 & 0,023 & $-0,588$ \\
\hline & 6 & 0,046 & 0,048 & 0,031 & 0,318 \\
\hline \multirow{2}{*}{$\mathrm{I}_{3}$} & 10 & 0,039 & 0,044 & 0,030 & $-0,325$ \\
\hline & 6 & 0,092 & 0,045 & 0,139 & 0,396 \\
\hline \multicolumn{6}{|c|}{ *: valor-p é significativo a um nível de significância de $10 \%$} \\
\hline & & ifipotio & - ú & is if & ância de $5 \%$ \\
\hline
\end{tabular}


Na região Centro-Oeste do país, houve significância nas variáveis $\mathrm{I}_{2} \mathrm{e} \mathrm{I}_{3}$, no teste da categoria de evidenciação do padrão contábil CPC, em 2010, a 5\% e 10\% de confiança respectivamente, no entanto os resultados não se repetiram para o ano seguinte. A variável $\mathrm{I}_{1}$, que não obteve significância em 2010, obteve em 2011, com um nível de significância de $10 \%$.

Para os testes em nível de disclosure, não se rejeita a hipótese nula, com exceção do índice $\mathrm{I}_{1}$, em 2011, com 5\% de confiança.

Tabela 13 - Teste de Mann-Whitney (Norte-Nordeste - 2010 e 2011)

\begin{tabular}{|c|c|c|c|c|c|}
\hline \multicolumn{6}{|c|}{ Norte-Nordeste $(\mathrm{N}=15)$} \\
\hline 2010 & $\mathrm{~N}$ & Média & Mediana & DP & Mann-Withney \\
\hline \multirow{2}{*}{ Variáveis } & \multicolumn{4}{|c|}{ A - Disclosure acima da Média } & z calculada \\
\hline & \multicolumn{4}{|c|}{ B - Disclosure abaixo da Média } & Valor P \\
\hline \multirow{2}{*}{$\mathrm{I}_{1}$} & 11 & 0,075 & 0,065 & 0,037 & $-1,436$ \\
\hline & 4 & 0,134 & 0,124 & 0,083 & $0,089 *$ \\
\hline \multirow{2}{*}{$\mathrm{I}_{2}$} & 11 & 0,036 & 0,034 & 0,017 & $-0,914$ \\
\hline & 4 & 0,061 & 0,056 & 0,050 & 0,206 \\
\hline \multirow{2}{*}{$\mathrm{I}_{3}$} & 11 & 0,105 & 0,060 & 0,107 & $-0,522$ \\
\hline & 4 & 0,075 & 0,070 & 0,068 & 0,330 \\
\hline \multirow{2}{*}{ Variáveis } & \multicolumn{4}{|c|}{ A - Evidenciação do Padrão CPC } & $\mathrm{z}$ calculada \\
\hline & \multicolumn{4}{|c|}{ B - Não evidenciação } & Valor P \\
\hline \multirow{2}{*}{$\mathrm{I}_{1}$} & 8 & 0,086 & 0,072 & 0,045 & 0,000 \\
\hline & 7 & 0,095 & 0,070 & 0,071 & 0,500 \\
\hline \multirow{2}{*}{$\mathrm{I}_{2}$} & 8 & 0,033 & 0,035 & 0,018 & $-1,042$ \\
\hline & 7 & 0,054 & 0,043 & 0,037 & 0,168 \\
\hline \multirow{2}{*}{$\mathrm{I}_{3}$} & 8 & 0,103 & 0,027 & 0,126 & $-0,463$ \\
\hline & 7 & 0,090 & 0,078 & 0,059 & 0,347 \\
\hline 2011 & $\mathrm{~N}$ & Média & Mediana & DP & Mann-Withney \\
\hline \multirow{2}{*}{ Variáveis } & \multicolumn{4}{|c|}{ A - Disclosure acima da Média } & $\mathrm{z}$ calculada \\
\hline & \multicolumn{4}{|c|}{ B - Disclosure abaixo da Média } & Valor P \\
\hline \multirow{2}{*}{$\mathrm{I}_{1}$} & 10 & 0,136 & 0,104 & 0,097 & 0,000 \\
\hline & 5 & 0,143 & 0,121 & 0,109 & 0,500 \\
\hline \multirow{2}{*}{$\mathrm{I}_{2}$} & 10 & 0,057 & 0,055 & 0,016 & $-0,490$ \\
\hline & 5 & 0,105 & 0,071 & 0,094 & 0,340 \\
\hline \multirow{2}{*}{$\mathrm{I}_{3}$} & 10 & 0,229 & 0,115 & 0,241 & $-0,612$ \\
\hline & 5 & 0,129 & 0,083 & 0,138 & 0,297 \\
\hline \multirow{2}{*}{ Variáveis } & \multicolumn{4}{|c|}{ A - Evidenciação do Padrão CPC } & $\mathrm{z}$ calculada \\
\hline & \multicolumn{4}{|c|}{ B - Não evidenciação } & Valor P \\
\hline \multirow{2}{*}{$\mathrm{I}_{1}$} & 8 & 0,147 & 0,090 & 0,106 & $-0,231$ \\
\hline & 7 & 0,129 & 0,108 & 0,094 & 0,433 \\
\hline \multirow{2}{*}{$\mathrm{I}_{2}$} & 8 & 0,056 & 0,055 & 0,013 & $-0,463$ \\
\hline & 7 & 0,093 & 0,071 & 0,080 & 0,347 \\
\hline \multirow{2}{*}{$\mathrm{I}_{3}$} & 8 & 0,215 & 0,103 & 0,249 & $-0,116$ \\
\hline & 7 & 0,174 & 0,083 & 0,180 & 0,478 \\
\hline
\end{tabular}

*: valor-p é significativo a um nível de significância de $10 \%$

**: valor-p é significativo a um nível de significância de 5\%

***: valor-p é significativo a um nível de significância de $1 \%$ 
Para a região Norte-Nordeste somente houve rejeição da hipótese I, de nível de disclosure, no ano de 2010, para o índice $\mathrm{I}_{1}$, com grau de significância de $10 \%$.

Tabela 14 - Teste de Mann-Whitney (Sudeste - 2010 e 2011)

\begin{tabular}{|c|c|c|c|c|c|}
\hline \multicolumn{6}{|c|}{ Sudeste $(\mathrm{N}=53)$} \\
\hline 2010 & $\mathrm{~N}$ & Média & Mediana & DP & Mann-Withney \\
\hline \multirow{2}{*}{ Variáveis } & \multicolumn{4}{|c|}{ A - Disclosure acima da Média } & $\mathrm{z}$ calculada \\
\hline & \multicolumn{4}{|c|}{ B - Disclosure abaixo da Média } & Valor P \\
\hline \multirow{2}{*}{$\mathrm{I}_{1}$} & 29 & 0,355 & 0,085 & 1,285 & $-1,412$ \\
\hline & 24 & 0,398 & 0,100 & 0,958 & $0,079 *$ \\
\hline \multirow{2}{*}{$\mathrm{I}_{2}$} & 29 & 0,037 & 0,037 & 0,020 & $-0,393$ \\
\hline & 24 & 0,053 & 0,052 & 0,846 & 0,347 \\
\hline \multirow{2}{*}{$\mathrm{I}_{3}$} & 29 & 0,072 & 0,043 & 0,084 & $-0,697$ \\
\hline & 24 & 0,107 & 0,052 & 0,145 & 0,243 \\
\hline \multirow{2}{*}{ Variáveis } & \multicolumn{4}{|c|}{ A - Evidenciação do Padrão CPC } & z calculada \\
\hline & \multicolumn{4}{|c|}{ B - Não evidenciação } & Valor P \\
\hline \multirow{2}{*}{$\mathrm{I}_{1}$} & 19 & 0,347 & 0,079 & 1,021 & $-1,224$ \\
\hline & 34 & 0,390 & 0,095 & 1,214 & 0,112 \\
\hline \multirow{2}{*}{$\mathrm{I}_{2}$} & 19 & 0,035 & 0,033 & 0,023 & $-0,872$ \\
\hline & 34 & 0,049 & 0,038 & 0,048 & 0,196 \\
\hline \multirow{2}{*}{$\mathrm{I}_{3}$} & 19 & 0,080 & 0,032 & 0,103 & $-0,723$ \\
\hline & 34 & 0,092 & 0,050 & 0,124 & 0,235 \\
\hline 2011 & $\mathrm{~N}$ & Média & Mediana & DP & Mann-Withney \\
\hline \multirow{2}{*}{ Variáveis } & \multicolumn{4}{|c|}{ A - Disclosure acima da Média } & $\mathrm{z}$ calculada \\
\hline & \multicolumn{4}{|c|}{ B - Disclosure abaixo da Média } & Valor P \\
\hline \multirow{2}{*}{$\mathrm{I}_{1}$} & 30 & 0,163 & 0,089 & 0,216 & $-1,149$ \\
\hline & 23 & 0,178 & 0,125 & 0,190 & 0,126 \\
\hline \multirow{2}{*}{$\mathrm{I}_{2}$} & 30 & 0,047 & 0,045 & 0,034 & $-0,951$ \\
\hline & 23 & 0,058 & 0,041 & 0,047 & 0,171 \\
\hline \multirow{2}{*}{$\mathrm{I}_{3}$} & 30 & 0,092 & 0,065 & 0,088 & $-0,538$ \\
\hline & 23 & 0,142 & 0,054 & 0,210 & 0,295 \\
\hline \multirow{2}{*}{ Variáveis } & \multicolumn{4}{|c|}{ A - Evidenciação do Padrão CPC } & $\mathrm{z}$ calculada \\
\hline & \multicolumn{4}{|c|}{ B - Não evidenciação } & Valor P \\
\hline \multirow{2}{*}{$\mathrm{I}_{1}$} & 33 & 0,150 & 0,085 & 0,205 & $-1,908$ \\
\hline & 20 & 0,201 & 0,134 & 0,202 & $0,028 * *$ \\
\hline \multirow{2}{*}{$\mathrm{I}_{2}$} & 33 & 0,045 & 0,041 & 0,030 & $-0,954$ \\
\hline & 20 & 0,061 & 0,051 & 0,052 & 0,170 \\
\hline \multirow{2}{*}{$\mathrm{I}_{3}$} & 33 & 0,094 & 0,064 & 0,085 & $-0,183$ \\
\hline & 20 & 0,146 & 0,061 & 0,226 & 0,427 \\
\hline
\end{tabular}

*: valor-p é significativo a um nível de significância de $10 \%$

**: valor-p é significativo a um nível de significância de 5\%

***: valor-p é significativo a um nível de significância de $1 \%$ 
Para a região Sudeste, foi possível rejeitar a hipótese nula I, em grau de disclosure, somente para o índice $\mathrm{I}_{1}$, em 2010. Em 2011, não foi possível rejeitar a hipótese nula para qualquer um dos índices.

Para o nível de adoção do padrão contábil com base no CPC, somente para o ano de 2011, pode-se rejeitar a hipótese nula para o índice $\mathrm{I}_{1}$ a 5\% de significância.

Tabela 15 - Teste de Mann-Whitney (Sul - 2010 e 2011)

\begin{tabular}{|c|c|c|c|c|c|}
\hline \multicolumn{6}{|c|}{ Sul $(\mathrm{N}=31)$} \\
\hline 2010 & $\mathrm{~N}$ & Média & Mediana & $\mathrm{DP}$ & Mann-Withney \\
\hline \multirow{2}{*}{ Variáveis } & \multicolumn{4}{|c|}{ A - Disclosure acima da Média } & $\mathrm{z}$ calculada \\
\hline & \multicolumn{4}{|c|}{ B - Disclosure abaixo da Média } & Valor P \\
\hline \multirow{2}{*}{$\mathrm{I}_{1}$} & 15 & 0,105 & 0,094 & 0,054 & $-2,451$ \\
\hline & 16 & 0,137 & 0,042 & 0,401 & $0,007 * * *$ \\
\hline \multirow{2}{*}{$\mathrm{I}_{2}$} & 15 & 0,046 & 0,053 & 0,029 & $-1,146$ \\
\hline & 16 & 0,045 & 0,042 & 0,016 & 0,132 \\
\hline \multirow{2}{*}{$\mathrm{I}_{3}$} & 15 & 0,134 & 0,058 & 0,161 & $-1,542$ \\
\hline & 16 & 0,238 & 0,087 & 0,401 & $0,065^{*}$ \\
\hline \multirow{2}{*}{ Variáveis } & \multicolumn{4}{|c|}{ A - Evidenciação do Padrão CPC } & $\mathrm{z}$ calculada \\
\hline & \multicolumn{4}{|c|}{ B - Não evidenciação } & Valor P \\
\hline \multirow{2}{*}{$\mathrm{I}_{1}$} & 10 & 0,118 & 0,103 & 0,060 & $-0,292$ \\
\hline & 21 & 0,123 & 0,109 & 0,059 & 0,394 \\
\hline \multirow{2}{*}{$\mathrm{I}_{2}$} & 10 & 0,055 & 0,055 & 0,029 & $-1,521$ \\
\hline & 21 & 0,041 & 0,041 & 0,018 & $0,068^{*}$ \\
\hline \multirow{2}{*}{$\mathrm{I}_{3}$} & 10 & 0,175 & 0,119 & 0,182 & $-0,465$ \\
\hline & 21 & 0,194 & 0,070 & 0,357 & 0,332 \\
\hline 2011 & $\mathrm{~N}$ & Média & Mediana & DP & Mann-Withney \\
\hline \multirow{2}{*}{ Variáveis } & \multicolumn{4}{|c|}{ A - Disclosure acima da Média } & z calculado \\
\hline & \multicolumn{4}{|c|}{ B - Disclosure abaixo da Média } & Valor P \\
\hline \multirow{2}{*}{$\mathrm{I}_{1}$} & 13 & 0,096 & 0,083 & 0,049 & $-1,761$ \\
\hline & 18 & 0,149 & 0,110 & 0,107 & $0,041 * *$ \\
\hline \multirow{2}{*}{$\mathrm{I}_{2}$} & 13 & 0,049 & 0,048 & 0,032 & $-0,440$ \\
\hline & 18 & 0,050 & 0,052 & 0,023 & 0,339 \\
\hline \multirow{2}{*}{$\mathrm{I}_{3}$} & 13 & 0,248 & 0,063 & 0,437 & $-0,160$ \\
\hline & 18 & 0,263 & 0,072 & 0,422 & 0,445 \\
\hline \multirow{2}{*}{ Variáveis } & \multicolumn{4}{|c|}{ A - Evidenciação do Padrão CPC } & U calculado \\
\hline & \multicolumn{4}{|c|}{ B - Não evidenciação } & Valor P \\
\hline \multirow{2}{*}{$\mathrm{I}_{1}$} & 14 & 0,109 & 0,104 & 0,057 & $-0,873$ \\
\hline & 17 & 0,142 & 0,109 & 0,110 & 0,199 \\
\hline \multirow{2}{*}{$\mathrm{I}_{2}$} & 14 & 0,054 & 0,051 & 0,032 & $-0,714$ \\
\hline & 17 & 0,046 & 0,049 & 0,022 & 0,247 \\
\hline \multirow{2}{*}{$\mathrm{I}_{3}$} & 14 & 0,248 & 0,078 & 0,421 & $-0,079$ \\
\hline & 17 & 0,264 & 0,063 & 0,435 & 0,477 \\
\hline
\end{tabular}

*: valor-p é significativo a um nível de significância de $10 \%$

**: valor-p é significativo a um nível de significância de 5\%

***: valor-p é significativo a um nível de significância de $1 \%$ 
$\mathrm{Na}$ análise dos resultados para a região Sul, pela primeira vez nos testes, houve repetição durante os dois anos de rejeição da hipótese nula, que ocorreu com o índice $\mathrm{I}_{1}$, nos testes de disclosure. Nesse mesmo teste, também houve rejeição, para o índice $\mathrm{I}_{3}$, em 2010.

Para a categoria nível de evidenciação do padrão contábil, não se rejeita a hipótese nula para o índice $\mathrm{I}_{2} \mathrm{em} 2010$.

Quadro 6 - Resumo dos Resultados dos Testes Não Paramétricos por Região

\begin{tabular}{|c|c|c|c|c|c|c|c|c|c|c|c|}
\hline \multicolumn{2}{|c|}{ Região } & \multicolumn{2}{|c|}{ Centro-Oeste } & \multicolumn{2}{|c|}{ Norte-Nordeste } & \multicolumn{2}{|c|}{ Sudeste } & \multicolumn{2}{|c|}{ Sul } & \multicolumn{2}{|c|}{ Total } \\
\hline Hipóteses & Variáveis & 2010 & 2011 & 2010 & 2011 & 2010 & 2011 & 2010 & 2011 & 2010 & 2011 \\
\hline \multirow{3}{*}{ I } & $\mathrm{I}_{1}$ & - & $* *$ & $*$ & - & $*$ & - & $* * *$ & $* *$ & $* * *$ & - \\
\hline & $\mathrm{I}_{2}$ & - & - & - & - & - & - & - & - & * & - \\
\hline & $\mathrm{I}_{3}$ & - & - & - & - & - & - & $*$ & - & $*$ & - \\
\hline \multirow{3}{*}{ II } & $\mathrm{I}_{1}$ & - & * & - & $* *$ & - & $* *$ & - & - & - & - \\
\hline & $\mathrm{I}_{2}$ & $* *$ & - & - & - & - & - & $*$ & - & $*$ & - \\
\hline & $\mathrm{I}_{3}$ & $*$ & - & - & - & - & - & - & - & $*$ & - \\
\hline \multicolumn{12}{|c|}{ *: valor-p é significativo a um nível de significância de $10 \%$} \\
\hline \multicolumn{12}{|c|}{ **: valor-p é significativo a um nível de significância de $5 \%$} \\
\hline
\end{tabular}

Dos 54 testes estatísticos não paramétricos realizados nas regiões brasileiras, 12 apresentaram diferenciação entre os grupos de análise com significância estatística. Resultado semelhante ao que ocorreu com a análise setorial.

Destaque há de ser dado para a região Sul, em que para a diferenciação entre grupos na hipótese I, para o índice $\mathrm{I}_{1}$, apresentou consistência durante os anos, com 99\% de nível de confiança em 2010 e 95\% de nível de confiança em 2011. Além do índice I 3 para a hipótese I e do índice $\mathrm{I}_{2}$ para a hipótese II, ambos em 2010.

As outras três regiões, também apresentaram índices com diferentes entre os grupos, com médias estatisticamente significativas, tanto para a hipótese I, como para a hipótese II, no entanto, eles não se repetiram entre os anos.

Da mesma forma que para a análise setorial, na análise regional os achados não são desprezíveis. Eles podem indicar que já se começa a encontrar uma diferenciação entre grupos 
com diferentes níveis de divulgação contábil, se observarmos certas regiões em determinados períodos.

Em razão da predominância de inconsistência entre os anos para a grande maioria dos testes significativos, não é possível generalizar o comportamento das variáveis para a amostra conforme hipóteses.

No entanto, os testes não permitem a completa rejeição das hipóteses nulas I e II, de que: (a) empresas com melhor qualidade da informação contábil captam créditos bancários em melhores condições de custo, que empresas com pior qualidade das informações contábeis, e (b) empresas que evidenciam seu padrão contábil baseado nas normas emanadas pelo CPC captam créditos bancários em melhores condições de custo, que empresas que não o evidenciam, uma vez que para algumas regiões, setores ou ano, alguns testes não rejeitam as hipóteses analisadas.

\subsubsection{Análise de Dados em Painel}

Essa análise serve de avaliação das hipóteses I e II, sob um olhar diferente, conforme descrito na seção 3.3 .2 (p. 90), por meio de outra técnica de investigação.

Antes de começar a colocar as variáveis em regressão de dados, é interessante olhar como as variáveis se relacionam entre si. A matriz de correlações de Pearson está anexada a este trabalho no apêndice I.

Ao observar essa matriz, é possível perceber, como era de se esperar, que as variáveis dependentes $\left(\mathrm{I}_{1}, \mathrm{I}_{2}, \mathrm{I}_{3}\right)$ a serem explicadas pelos modelos, têm coeficientes de correlação altos com suas respectivas variáveis defasadas no tempo $\left(I_{1(-1)}, I_{2(-1)}\right.$ e $\left.I_{3(-1)}\right)$, com valores $0,53,0,63$ e 0,79, respectivamente. Em relação às outras variáveis, os coeficientes não passam de 0,29.

Entre as variáveis independentes, as maiores correlações se deram entre as variáveis "discl" e as variáveis dummy "Dcpc", "Daudit" e "Dbig4", com 0,56, 0,64 e 0,35, respectivamente; entre a variável "Dbig4" e a "Daudit", com 0,44. Aparentemente não sugerem preocupações, mas testes para verificação de multicolinearidade foram aplicados ao final da estimação dos parâmetros. 
Primeiramente, os dados dos 115 cortes transversais utilizados nos testes não paramétricos são modelados pelo método dos mínimos quadrados ordinários empilhados (pooled ordinary least squares) com dados de dois anos, e seus pressupostos são devidamente testados, conforme modelo previsto:

$$
\begin{aligned}
I_{i, t, j}=\propto+\beta 1 . & \left(\operatorname{discl}_{i, t-1}\right)+\beta 2 .\left(\text { Dcpc }_{i, t-1}\right)+\gamma 1 \cdot\left(\text { size }_{i, t-1}\right)+\gamma 2 \cdot\left(\text { roe }_{i, t-1}\right) \\
& +\gamma 3 \cdot\left(\text { debt }_{i, t-1}\right)+\gamma 4 \cdot\left(I_{i, t-1, j}\right)+\delta 1 \cdot\left(\text { Daudit }_{i, t-1}\right)+\delta 2 .\left(\text { Dbig }_{i, t-1}\right) \\
& +\sum_{k=2}^{5} \varphi_{k} \cdot\left(\text { Dsector }_{k, i}\right)+\sum_{m=2}^{4} \omega_{m} \cdot\left(\text { Dregion }_{m, i}\right)+\psi t+\varepsilon_{i, t, j}
\end{aligned}
$$

Seguem abaixo os resultados da estimação dos parâmetros pelo método POLS, com os

\begin{tabular}{|c|c|c|c|c|c|c|}
\hline \multirow[b]{2}{*}{ Variáveis } & \multicolumn{2}{|c|}{ MQO $\left(\mathrm{I}_{1}\right)$} & \multicolumn{2}{|c|}{ MQO $\left(I_{2}\right)$} & \multicolumn{2}{|c|}{$\mathrm{MQO}\left(\mathrm{I}_{3}\right)$} \\
\hline & Coef. & p-valor & Coef. & p-valor & Coef. & p-valor \\
\hline Const & $-0,057$ & 0,621 & $-0,001$ & 0,951 & $-0,029$ & 0,549 \\
\hline $\operatorname{discl}_{-1}$ & 0,009 & 0,936 & $-0,006$ & 0,483 & 0,002 & 0,958 \\
\hline Dcpc $_{-1}$ & 0,052 & 0,327 & $-0,004$ & 0,281 & $-0,021$ & 0,351 \\
\hline size $_{-1}$ & $-0,000$ & 0,652 & $-0,000$ & 0,467 & $-0,000$ & $0,056^{*}$ \\
\hline roe $_{-1}$ & $-0,009$ & 0,932 & $-0,003$ & 0,645 & $-0,207$ & $0,000 * * *$ \\
\hline debt $_{-1}$ & $-0,003$ & 0,975 & 0,018 & $0,042 * *$ & 0,200 & $0,001 * * *$ \\
\hline $\mathrm{I}_{1(-1)} / \mathrm{I}_{2(-1)} / \mathrm{I}_{3(-1)}$ & 1,037 & $0,000 * * *$ & 0,612 & $0,000 * * *$ & 0,792 & $0,000 * * *$ \\
\hline Daudit $_{-1}$ & 0,052 & 0,330 & 0,007 & 0,105 & 0,043 & $0,069 *$ \\
\hline Dbig4 -1 & $-0,041$ & 0,502 & $-0,009$ & $0,057^{*}$ & $-0,001$ & 0,974 \\
\hline Dse & 0,020 & 0,679 & $-0,001$ & 0,758 & $-0,051$ & $0,023 * *$ \\
\hline Dco & 0,234 & $0,002 * * *$ & 0,003 & 0,620 & $-0,053$ & 0,105 \\
\hline Dnne & $-0,016$ & 0,810 & 0,004 & 0,490 & $-0,032$ & 0,267 \\
\hline Dserv & $-0,030$ & 0,720 & 0,010 & 0,146 & 0,039 & 0,279 \\
\hline Dagro & $-0,011$ & 0,890 & 0,003 & 0,642 & 0,0149 & 0,672 \\
\hline Dcons & 0,015 & 0,835 & 0,013 & $0,019 * *$ & 0,0056 & 0,858 \\
\hline Dbase & $-0,069$ & 0,341 & 0,009 & 0,113 & 0,0182 & 0,565 \\
\hline $\mathrm{Dt}$ & 0,062 & 0,131 & 0,015 & $0,000 * * *$ & 0,0696 & $0,000 * * *$ \\
\hline \multicolumn{7}{|l|}{ Testes de Validação } \\
\hline R-quadrado & 0,354 & & 0,501 & & 0,717 & \\
\hline R-quadrado ajustado & 0,305 & & 0,464 & & 0,696 & \\
\hline $\mathrm{F}(16,213)(\mathrm{a})$ & 7,292 & 0,000 & 13,399 & 0,000 & 33,708 & 0,000 \\
\hline Teste RESET (b) & 38,605 & 0,000 & 1,15185 & 0,318 & 42,093 & 0,000 \\
\hline Teste White (LM) (c) & 219,261 & 0,000 & 147,693 & 0,124 & 202,679 & 0,000 \\
\hline Breush-Pagan/Cook-Weisberg (d) & $1.778,630$ & 0,000 & 56,83 & 0,000 & 442,270 & 0,000 \\
\hline Teste Normalidade Resíduos (e) & 955,389 & 0,000 & 33,3812 & 0,000 & 148,678 & 0,000 \\
\hline Normalidade Jarque-Bera (f) & $51.000,000$ & 0,000 & 145,400 & 0,000 & $4.213,000$ & 0,000 \\
\hline
\end{tabular}
respectivos testes de validação dos modelos.

Tabela 16 - MQO agrupado, usando 230 observações, incluídas 115 unidades de corte transversal e com-

\footnotetext{
${ }^{124}$ Foi utilizado o software Gretl, versão 1.9 .8 , para estimação dos modelos.
} 


\begin{tabular}{|l|r|r|r|r|r|r|}
\hline Norm. Skewness/Kurtosis (g) & 0,000 & 0,000 & 42,690 & 0,000 & 0,000 & 0,000 \\
\hline Teste de não-linearidade (h) & 15,286 & 0,009 & 16,4717 & 0,006 & 28,199 & 0,000 \\
\hline
\end{tabular}

(a) Análise da estatística F - Hipótese nula: todos os parâmetros equivalem a zero; (b) Teste RESET para especificação - Hipótese nula: a especificação é adequada (c) Teste de White (Lagrange multiplier) para a heterocedasticidade - Hipótese nula: sem heterocedasticidade; (d) Teste de Breush-Pagan/Cook-Weisberg para a heterocedasticidade - Hipótese nula: sem heterocedasticidade; (e) Teste da normalidade dos resíduos - Hipótese nula: o erro tem distribuição Normal; (f) Teste da normalidade de Jarque Bera - Hipótese nula: normalidade; (g) Teste de assimetria e curtose para normalidade - Hipótese nula: normalidade; (h) Teste de não linearidade (quadrados) - Hipótese nula: a relação é linear. ${ }^{125}$

Pela análise dos dados em painel, empilhados, os modelos possuem parâmetros de regressão significativos, no entanto violam os pressupostos de linearidade, normalidade e heterocedasticidade em conjunto.

Quanto à linearidade, nos testes realizados para os três índices analisados $\left(\mathrm{I}_{1}, \mathrm{I}_{2}, \mathrm{I}_{3}\right)$, a hipótese nula de relação linear foi rejeitada, com probabilidades $0,009,0,006,0,000$, respectivamente, todas abaixo de $1 \%$.

No que se refere à normalidade dos resíduos, para todos os testes realizados, teste da normalidade dos resíduos, teste da normalidade de Jarque Bera e teste de assimetria e curtose para normalidade, nos três índices analisados $\left(\mathrm{I}_{1}, \mathrm{I}_{2}, \mathrm{I}_{3}\right)$ a hipótese nula de normalidade é rejeitada com probabilidade bem abaixo de $1 \%$.

E por fim, quanto ao pressuposto da homocedasticidade, para os dois testes realizados, teste de White (Lagrange multiplier) e teste de Breush-Pagan/Cook-Weisberg, a hipótese nula de ausência de heterocedasticidade, é rejeitada com probabilidade bem abaixo de 1\%, exceção ao índice $\mathrm{I}_{2}$, que não teve a hipótese rejeitada para o teste de White com probabilidade de 0,124 .

Na tentativa de consertar os problemas que inviabilizavam a estimação dos parâmetros, optou-se primeiramente por realizar transformações Box-Cox nas variáveis dependentes e independentes. Segundo Fávero et al. (2009, p. 363), em diversas áreas do conhecimento, dentre elas a contabilidade, seria estranho supor que determinada variável de estudo fosse influenciada somente por meio de relação linear de variáveis explicativas.

${ }^{125}$ Os testes de Breusch-Pagan/Cook-Weisberg, Jarque Bera e de Assimetria e Curtose (Skewnees/Kustorsis) foram realizados com auxílio do software Stata, versão 11, os demais testes foram realizados com auxílio do software Gretl 1.9.8. 
Pela transformação proposta por Box e Cox substitui-se a variável dependente Y e as independentes $\mathrm{X}_{\mathrm{n}}$, por $\left(\mathrm{Y}^{\lambda}-1\right) / \lambda \mathrm{e}\left(\mathrm{X}_{\mathrm{n}}{ }^{\theta}-1\right) / \theta$, respectivamente, em que $\lambda$ e $\theta$ são os parâmetros da transformação.

Essas expressões pareceriam indeterminadas quando $\lambda$ e $\theta$ fossem zero, no entanto, elaborando-se suas expansões em série de Taylor (Ibid., p. 364), para $\lambda=0$ teríamos $\left(\mathrm{Y}^{\lambda}-1\right) / \lambda=$ $\ln \mathrm{Y}$.

Segue abaixo a tabela 17 com os resultados das transformações Box-Cox com detalhamento dos parâmetros calculados.

Tabela 17 - Parâmetros das transformações Box-Cox das variáveis ${ }^{126}$

\begin{tabular}{|c|c|c|}
\hline Variável & $\lambda$ & $\begin{array}{c}\text { Transfor- } \\
\text { mação }\end{array}$ \\
\hline $\mathrm{I}_{1}$ & $-0,278$ & $\left(\mathrm{I}_{1}^{\lambda}-1\right) / \lambda$ \\
\hline $\mathrm{I}_{2}$ & 0,278 & $\left(\mathrm{I}_{2}^{\lambda}-1\right) / \lambda$ \\
\hline $\mathrm{I}_{3}$ & 0,000 & $\ln \mathrm{I}_{3}$ \\
\hline $\mathrm{I}_{1(-1)}$ & 0,000 & $\ln \mathrm{I}_{1(-1)}$ \\
\hline $\mathrm{I}_{2(-1)}$ & 0,000 & $\ln \mathrm{I}_{2(-1)}$ \\
\hline $\mathrm{I}_{3(-1)}$ & 0,000 & $\ln \mathrm{I}_{3(-1)}$ \\
\hline size & 0,631 & $\left(\operatorname{size}^{\lambda}-1\right) / \lambda$ \\
\hline debt & 0,732 & $\begin{array}{c}\left(\operatorname{debt}^{\lambda}-1\right) / \\
\lambda\end{array}$ \\
\hline discl & 1,035 & $\begin{array}{c}\left(\operatorname{discl}^{\lambda}-1\right) / \\
\lambda\end{array}$ \\
\hline
\end{tabular}

Fonte: elaborado pelo autor

Além deste procedimento, concomitantemente, também se decidiu pela eliminação dos outliers, para isso foi utilizada a técnica de winsorização, que consiste na substituição dos registros com valores acima ou abaixo de determinados limites, inferiores ou superiores, pelo maior e menor valor remanescente do limite estabelecido (Barnett \& Lewis, 1994, apud Brito, 2010, p. 121).

O limite utilizado para emprego da técnica foi o limite da curva Box-Plot ${ }^{127}$, em que foi constatada a necessidade de alteração nos outliers das variáveis $I_{1}, I_{2}, I_{1(-1)}, I_{2(-1)}$ e roe.

Seguem abaixo os resultados das regressões pelo MQO dos dados em painel, com os dados ajustados.

\footnotetext{
${ }^{126}$ Foi utilizado o software Action, versão 2.4, para cálculo dos parâmetros.

${ }^{127}$ Foi utilizado o software Action, versão 2.4, para elaboração dos gráficos Box-Plot.
} 
Tabela 18 - MQO agrupado com dados ajustados, usando 230 observações, incluídas 115 unidades de corte transversal e comprimento da série temporal de 2 anos

\begin{tabular}{|c|c|c|c|c|c|c|}
\hline POLS & \multicolumn{2}{|c|}{$\operatorname{MQO}\left(\mathrm{I}_{1}^{\lambda}-1\right) / \lambda^{\prime}$} & \multicolumn{2}{|c|}{$\operatorname{MQO}\left(\mathrm{I}_{2}^{\lambda}-1\right) / \lambda^{\prime}$} & \multicolumn{2}{|c|}{$\mathrm{MQO} \ln \mathrm{I}_{3}$} \\
\hline Variáveis & Coef. & p-valor & Coef. & p-valor & Coef. & p-valor \\
\hline const & $-0,428$ & 0,483 & $-1,345$ & $0,000 * * *$ & $-0,171$ & 0,565 \\
\hline$\left(\operatorname{discl}^{\lambda}-1\right) / \lambda$ & 0,025 & 0,949 & $-0,076$ & 0,293 & $-0,173$ & 0,411 \\
\hline Dcpc & $-0,013$ & 0,943 & $-0,008$ & 0,825 & 0,021 & 0,835 \\
\hline$\left(\operatorname{size}^{\lambda}-1\right) / \lambda$ & $-0,000$ & 0,667 & $-0,000$ & 0,640 & $-0,000$ & $0,096^{*}$ \\
\hline roe' & 0,478 & 0,210 & $-0,023$ & 0,743 & $-0,699$ & $0,001 * * *$ \\
\hline$\left(\mathrm{debt}^{\lambda}-1\right) / \lambda$ & 0,319 & 0,340 & 0,135 & $0,032 * *$ & 1,454 & $0,000 * * *$ \\
\hline $\ln \mathrm{I}_{1(-1)},, \ln \mathrm{I}_{2(-1)},, \ln \mathrm{I}_{3(-1)}$ & 1,241 & $0,000 * * *$ & 0,258 & $0,000 * * *$ & 0,683 & $0,000 * * *$ \\
\hline Daudit & 0,228 & 0,235 & 0,053 & 0,139 & 0,140 & 0,182 \\
\hline Dbig4 & $-0,458$ & $0,036 * *$ & $-0,082$ & $0,044 * *$ & $-0,216$ & $0,069 *$ \\
\hline Dse & $-0,005$ & 0,976 & $-0,019$ & 0,568 & $-0,098$ & 0,309 \\
\hline Dco & 0,463 & $0,080 *$ & 0,013 & 0,790 & $-0,115$ & 0,427 \\
\hline Dnne & 0,087 & 0,713 & 0,035 & 0,419 & 0,013 & 0,916 \\
\hline Dserv & 0,079 & 0,791 & 0,091 & 0,102 & 0,272 & $0,093 *$ \\
\hline Dagro & $-0,489$ & $0,085^{*}$ & 0,024 & 0,653 & 0,013 & 0,934 \\
\hline Dcons & 0,106 & 0,675 & 0,113 & $0,019 * *$ & 0,248 & $0,075^{*}$ \\
\hline Dbase & $-0,344$ & 0,184 & 0,070 & 0,147 & 0,159 & 0,259 \\
\hline $\mathrm{Dt}$ & 0,409 & $0,005 * * *$ & 0,106 & $0,000 * * *$ & 0,301 & $0,000 * * *$ \\
\hline \multicolumn{7}{|l|}{ Testes de Validação } \\
\hline R-quadrado & 0,519 & & 0,576 & & 0,830 & \\
\hline R-quadrado ajustado & 0,483 & & 0,545 & & 0,817 & \\
\hline $\mathrm{F}(16,213)(\mathrm{a})$ & 14,364 & 0,000 & 18,116 & 0,000 & 64,859 & 0,000 \\
\hline Teste RESET F(2,211) (b) & 0,328 & 0,720 & 2,331 & 0,100 & 0,909 & 0,405 \\
\hline Teste White (LM) (c) & 162,950 & 0,023 & 140,705 & 0,227 & 128,405 & 0,498 \\
\hline Breush-Pagan/Cook-Weisberg (d) & 0,010 & 0,933 & 0,410 & 0,522 & 8,460 & 0,004 \\
\hline Teste Normalidade Resíduos (e) & 16,763 & 0,000 & 6,601 & 0,037 & 6,334 & 0,042 \\
\hline Normalidade Jarque-Bera (f) & 19,950 & 0,000 & 8,711 & 0,013 & 6,650 & 0,036 \\
\hline Norm. Skewness/Kurtosis (g) & 9,640 & 0,008 & 7,440 & 0,024 & 5,680 & 0,059 \\
\hline Teste de não-linearidade (h) & 5,403 & 0,369 & 11,124 & 0,049 & 2,033 & 0,845 \\
\hline
\end{tabular}

(a) Análise da estatística F - Hipótese nula: todos os parâmetros equivalem a zero; (b) Teste RESET para especificação - Hipótese nula: a especificação é adequada (c) Teste de White (Lagrange multiplier) para a heterocedasticidade - Hipótese nula: sem heterocedasticidade; (d) Teste de Breush-Pagan/Cook-Weisberg para a heterocedasticidade - Hipótese nula: sem heterocedasticidade; (e) Teste da normalidade dos resíduos - Hipótese nula: o erro tem distribuição Normal; (f) Teste da normalidade de Jarque Bera - Hipótese nula: 
normalidade; (g) Teste de assimetria e curtose para normalidade - Hipótese nula: normalidade; (h) Teste de não linearidade (quadrados) - Hipótese nula: a relação é linear. As variáveis marcadas com apóstrofo ao final passaram pelo processo de winsorização.

Pela análise dos dados ajustados em painel, empilhados, os modelos possuem parâmetros de regressão significativos, e apenas o índice $\left(\mathrm{I}_{1}{ }^{\lambda}-1\right) / \lambda$ viola o pressuposto da normalidade dos erros.

No que se refere à linearidade, nos testes realizados para os três índices analisados $\left(\left(\mathrm{I}_{1}{ }^{\lambda}\right.\right.$ -1) / $\lambda$, $\left(\mathrm{I}_{2}{ }^{\lambda}-1\right) / \lambda$ e $\left.\ln \mathrm{I}_{3}\right)$, a hipótese nula de relação linear não foi rejeitada, com probabilidades $0,369,0,049$ e 0,845 , respectivamente, todas acima de $1 \%$.

Quanto ao pressuposto da homocedasticidade, o teste de Breush-Pagan/Cook-Weisberg rejeita a hipótese nula de ausência de heterocedasticidade para o índice $\ln _{3}$, com probabilidade de 0,004, no entanto, o teste de White (Lagrange multiplier) não rejeita a hipótese nula de ausência de heterocedasticidade com probabilidades de 0,023, 0,227 e 0,498, respectivamente para os índices analisados, todas acima de $1 \%$.

E por fim, quanto à normalidade dos resíduos, para todos os testes realizados, teste da normalidade dos resíduos, teste da normalidade de Jarque Bera e teste de assimetria e curtose para normalidade, para os três índices $\left(\mathrm{I}_{2}{ }^{\lambda}-1\right) / \lambda$ e $\ln \mathrm{I}_{3}$, a hipótese nula de normalidade não é rejeitada com probabilidade acima de $1 \%$. No entanto para o índice $\left(\mathrm{I}_{1}{ }^{\lambda}-1\right) / \lambda$, a hipótese nula de normalidade é rejeitada nos três testes com probabilidade abaixo de $1 \%(0,000,0,000$ e $0,008)$.

Quanto ao problema de multicolinearidade, foram verificados os fatores de inflação da variância das variáveis, pelas estatísticas VIF (Variance Inflation Factor). Segundo Fávero (2009, p. 359), na prática, valores de VIF acima de 5\% podem conduzir problemas de multicolinearidade. Conforme tabela 19 abaixo, não há indícios de problemas de multicolinearidade nos modelos estimados.

Tabela 19 - Fatores de Inflação da Variância (VIF) das variáveis

\begin{tabular}{|c|c|c|c|}
\hline Variáveis & $\left(\mathrm{I}_{1}{ }^{\lambda}-1\right) / \lambda$ & $\left(\mathrm{I}_{2}{ }^{\lambda}-1\right) / \lambda$ & $\ln \mathrm{I}_{3}$ \\
\hline discl & 2,667 & 2,524 & 2,538 \\
\hline Dcpc & 1,842 & 1,832 & 1,833 \\
\hline$\left(\right.$ size $\left.^{\lambda}-1\right) / \lambda$ & 1,407 & 1,394 & 1,393 \\
\hline roe & 1,225 & 1,222 & 1,234 \\
\hline$\left(\right.$ debt $\left.^{\lambda}-1\right) / \lambda$ & 1,158 & 1,169 & 2,670 \\
\hline
\end{tabular}




\begin{tabular}{|c|c|c|c|}
\hline $\ln \mathrm{I}_{1(-1)}, \ln \mathrm{I}_{2(-1)}, \ln \mathrm{I}_{3(-1)}$ & 1,242 & 1,162 & 2,705 \\
\hline Daudit & 1,995 & 1,996 & 2,000 \\
\hline Dbig4 & 1,413 & 1,418 & 1,411 \\
\hline Dse & 1,623 & 1,633 & 1,659 \\
\hline Dco & 1,810 & 1,827 & 1,824 \\
\hline Dnne & 1,448 & 1,417 & 1,419 \\
\hline Dserv & 2,545 & 2,512 & 2,512 \\
\hline Dagro & 2,793 & 2,849 & 2,885 \\
\hline Dcons & 2,902 & 2,962 & 2,954 \\
\hline Dbase & 2,598 & 2,609 & 2,608 \\
\hline Dt & 1,121 & 1,093 & 1,090 \\
\hline
\end{tabular}

O passo seguinte foi realizar os diagnósticos para definição de qual seria a melhor adequação dos painéis: dados empilhados em MQO, dados em painel com efeitos fixos ou dados em painel com efeitos aleatórios.

Tabela 20 - Testes de Diagnóstico de Painel

\begin{tabular}{|c|c|c|c|c|c|c|c|c|c|}
\hline \multirow{2}{*}{$\begin{array}{c}\text { Testes de } \\
\text { Painel }\end{array}$} & \multicolumn{2}{|c|}{$\left(\mathrm{I}_{1}^{\lambda}-1\right) / \lambda$} & \multirow{2}{*}{ Parcial } & \multicolumn{2}{|c|}{$\left(\mathrm{I}_{2}{ }^{\lambda}-1\right) / \lambda$} & \multirow{2}{*}{ Parcial } & \multicolumn{2}{|c|}{$\ln \mathrm{I}_{3}$} & \multirow{2}{*}{ Parcial } \\
\hline & Estat. & p-valor & & Estat. & p-valor & & Estat. & p-valor & \\
\hline Chow & 2,191 & 0,000 & $\mathrm{EF}$ & 2,758 & 0,000 & $\mathrm{EF}$ & 2,768 & 0,000 & $\mathrm{EF}$ \\
\hline Breusch-Pagan & 4,238 & 0,040 & EA & 2,273 & 0,132 & POLS & 0,125 & 0,724 & POLS \\
\hline Hausman & 139,198 & 0,000 & $\mathrm{EF}$ & 163,437 & 0,000 & $\mathrm{EF}$ & 110,878 & 0,000 & $\mathrm{EF}$ \\
\hline Diagnóstico & \multicolumn{3}{|c|}{ Efeitos Fixos } & \multicolumn{3}{|c|}{ Efeitos Fixos } & \multicolumn{3}{|c|}{ Efeitos Fixos } \\
\hline
\end{tabular}

Para os três modelos estimados, a melhor adequação está em dados de painel com efeitos fixos, ou seja, são consideradas as alterações nos cortes transversais de forma a levar em conta a individualidade das empresas analisadas.

Tabela 21 - Painel de Efeitos Fixos com dados ajustados, usando 230 observações, incluídas 115 unidades de corte transversal e comprimento da série temporal de 2 anos

\begin{tabular}{|c|c|c|c|c|c|c|}
\hline Painel de Efeitos Fixos & \multicolumn{2}{|c|}{$\operatorname{EF}\left(\mathrm{I}_{1}{ }^{\lambda}-1\right) / \lambda$} & \multicolumn{2}{|c|}{$\mathrm{EF}\left(\mathrm{I}_{2}^{\lambda}-1\right) / \lambda$} & \multicolumn{2}{|c|}{$\mathrm{EF} \ln \mathrm{I}_{3}$} \\
\hline Variáveis & Coeficiente & p-valor & Coeficiente & p-valor & Coeficiente & p-valor \\
\hline Const & $-2,308$ & $0,072 *$ & $-2,576$ & $0,000 * * *$ & $-2,588$ & $0,000 * * *$ \\
\hline discl & 1,073 & $0,068^{*}$ & 0,053 & 0,596 & 0,063 & 0,830 \\
\hline Dcpc & 0,121 & 0,653 & 0,013 & 0,787 & 0,025 & 0,852 \\
\hline$\left(\operatorname{size}^{\lambda}-1\right) / \lambda$ & 0,000 & 0,815 & 0,000 & 0,153 & 0,000 & 0,466 \\
\hline roe & $-0,714$ & 0,182 & $-0,156$ & $0,090^{*}$ & $-0,258$ & 0,338 \\
\hline$\left(\mathrm{deb}^{\lambda}-1\right) / \lambda$ & 2,157 & $0,060 *$ & 0,348 & $0,076^{*}$ & 2,446 & $0,000 * * *$ \\
\hline Daudit & $-0,201$ & 0,615 & 0,040 & 0,559 & 0,374 & $0,063 *$ \\
\hline Dbig4 & $-1,232$ & $0,077^{*}$ & $-0,236$ & $0,049 * *$ & $-0,871$ & $0,013 * *$ \\
\hline $\mathrm{Dt}$ & $-0,032$ & 0,826 & 0,026 & 0,303 & 0,124 & $0,089 *$ \\
\hline $\ln I_{1(-1)}, \ln I_{2(-1)}, \ln I_{3(-1)}$ & $-0,340$ & $0,063^{*}$ & $-0,118$ & $0,001 * * *$ & $-0,152$ & $0,097 *$ \\
\hline Testes de Validação & & & & & & \\
\hline R-quadrado & 0,857 & & 0,893 & & 0,957 & \\
\hline R-quadrado ajustado & 0,690 & & 0,769 & & 0,907 & \\
\hline
\end{tabular}




\begin{tabular}{|c|c|c|c|c|c|c|}
\hline $\mathrm{F}$ (a) & 5,152 & 0,000 & 2,758 & 0,000 & 19,262 & 0,000 \\
\hline Teste Normalidade Resíduos (b) & 41,432 & 0,000 & 19,184 & 0,000 & 9,601 & 0,008 \\
\hline
\end{tabular}

Apesar de o diagnóstico de painel apontar maior eficiência para o painel de efeitos fixos, os testes de normalidade sugerem que os modelos violam este pressuposto fundamental para a estimação dos parâmetros, com probabilidades para os três índices estudados de 0,000, 0,000 e 0,008, respectivamente, o que indica rejeição da hipótese nula de distribuição normal para erros.

Isto posto, a análise se volta para os dois modelos que passaram em todos os pressupostos no método dos mínimos quadrados ordinários empilhados, e, portanto, possuem consistência para se analisar seus parâmetros.

Logo, os modelos com as variáveis dependentes $I_{2}$ (ajustada para $\left(\mathrm{I}_{2}^{\lambda}-1\right) / \lambda^{\prime}$ ) e $\mathrm{I}_{3}$ (ajustada para $\operatorname{lnI}_{3}$ ) servem de base para as conclusões sobre os parâmetros. E eles apontam para as mesmas conclusões, os parâmetros estimados para as variáveis "discl" e "Dcpc", em ambas as regressões, não são significativos, ou seja, nesse período de dois anos de dados analisados nessas 115 empresas, tanto o nível de disclosure como a evidenciação do padrão contábil internacional não influenciam significativamente o custo de captação bancária de empresas de médio porte.

Ao analisar as demais varáveis estudadas em ambos nos modelos, vê-se primeiramente que suas respectivas variáveis defasadas no tempo em um ano $\left(\operatorname{lnI}_{2(-1)}\right.$ e $\left.\ln \mathrm{I}_{3(-1)}\right)$ se apresentaram significativamente relevantes, ou seja, o patamar de custo de crédito é fortemente influenciado pelos níveis de custo de crédito dos anos anteriores, sugerindo uma base do custo de captação no relacionamento com as instituições bancárias no tempo.

A variável endividamento $\left(\left(\operatorname{debt}^{\lambda}-1\right) / \lambda\right)$ também se apresentou significativa e com sinal positivo, conforme previsto na descrição da variável no desenvolvimento do trabalho, ou seja, quanto maior o nível de endividamento, mais as empresas tendem a gastar com o custo de suas dívidas bancárias.

A variável dummy 'Dbig4' se apresentou significativa e com sinal negativo, o que permite inferir sobre a importância da qualidade dessas informações contábeis, uma vez que se tem 
uma relação direta do grau de confiança nas informações revisadas por empresas de auditoria 'Big Four' com o custo de crédito. O mesmo não ocorreu nos resultados para todo o universo de empresas de auditoria, uma vez que a variável dummy 'Daudit' não se apresentou significativa. O resultado indica que, de fato, fontes confiáveis de informação fazem diferença no momento da concessão de crédito, nesse caso a confiança está associada ao 'carimbo' de grandes empresas de auditoria.

A variável dummy de tempo, Dt, se apresentou significativa, ou seja, fatores macroeconômicos tiveram influência nos preços do crédito para esses dois anos analisados. Flutuações em taxas de juros, índices de preços e taxas de câmbio, entre outras, certamente interferiram na precificação das taxas de juros pactuadas entre as empresas e bancos nesses anos no segmento estudado.

A variável dummy do setor de consumo, Dcons, em relação ao setor de comércio, também se apresentou significativa, o que permite dizer que em pelo menos entre dois setores de atividade econômica, indústria de bens de consumo e comércio, existe uma diferenciação de custo de captação bancária, nesse caso os custos de captação apresentados pelo setor de comércio foram menores.

Ademais, para o modelo de regressão do $\mathrm{I}_{3}$ (ajustado para $\ln \mathrm{I}_{3}$ ), tanto a proxy de tamanho $\left(\left(\operatorname{size}^{\lambda}-1\right) / \lambda\right)$, como a de rentabilidade (roe'), se demonstraram como variáveis significativas, conforme previsto na descrição das variáveis apresentadas anteriormente na pesquisa. Ou seja, conforme as empresas aumentam de tamanho e/ou se tornam mais rentáveis, elas obtêm um prêmio no momento de captar novos empréstimos.

A variável dummy do setor de serviços, Dserv, em relação ao setor de comércio, também se apresentou significativa. Analogamente à variável dummy para o setor de indústria de bens de consumo, Dcons, o setor de serviços obteve taxas de captação em níveis mais elevados que o setor de comércio.

Portanto, as hipóteses I (nível de qualidade da informação contábil tem relação significativa e inversamente proporcional com os custos dos créditos bancários) e II (evidenciação do padrão contábil baseado nas normas do CPC tem relação significativa e inversa com os custos 
dos créditos bancários), baseando-se na análise de dados em painel, deveriam ser rejeitadas, uma vez que não é possível inferir sobre os parâmetros.

\subsection{Análise qualitativa}

\subsubsection{Aspectos das entrevistas}

Para complementar as análises quantitativas baseadas nas informações colhidas das demonstrações contábeis das empresas, a ponta tomadora de crédito, e permitir conclusões mais acuradas sobre os aspectos de crédito a empresas de pequeno e médio porte, verificaram-se aspectos pertinentes ao trabalho junto à ponta fornecedora de crédito, as instituições financeiras.

Neste sentido, foi realizado um levantamento de natureza exploratória, com base em entrevistas semiestruturadas, com visitas realizadas pessoalmente, junto a experientes executivos atuantes no mercado financeiro brasileiro, especificamente das áreas de análise e concessão de crédito a empresas de "Middle Market".

O objetivo deste levantamento foi entender os procedimentos de concessão de crédito das instituições financeiras, e perceber como os aspectos concernentes à informação contábil fazem parte desse processo, dentre os diversos instrumentos de verificação de riscos de crédito existentes no mercado de crédito. Além disso, procurou-se obter opiniões dos entrevistados acerca da qualidade da informação contábil, a partir da adoção de um novo padrão internacional de contabilidade para pequenas e médias empresas, e preparo das instituições para análise de informações contábeis diante desse novo paradigma. Por fim, buscou-se investigar até que ponto uma melhora na qualidade da informação contábil advinda com um novo padrão contábil poderia se traduzir em melhores custos de captação para empresas de menor porte.

Assim sendo, após contatos telefônicos com onze instituições financeiras, foram agendadas entrevistas com nove bancos, dos quais quatro se tratavam de bancos de varejo, com departamentos ${ }^{128}$ especializados em crédito para empresas de menor porte, e cinco eram bancos de atacado, como foco de atuação no mercado de médias empresas. As reuniões foram realizadas até o momento em que se considerou haver atingido um ponto de saturação das respostas.

${ }^{128}$ Localizados na cidade de São Paulo 
Embora a amostra tenha sido escolhida por conveniência, apresentou-se bastante representativa, na medida em que compreendeu no seu total, instituições financeiras que concederam mais de $80 \%$ do crédito a médias empresas, entre as maiores instituições bancárias em crédito para o setor no Brasil, conforme Tabela 2 (p. 68).

Conforme carta de conforto e sigilo, adaptada do modelo de Verrone (2007, p. 155) (Apêndice B), nesta pesquisa, não foram identificadas as instituições financeiras, tão pouco, as pessoas participantes das reuniões, sendo feitas referências somente em relação ao foco das instituições (varejo e atacado), se necessário fosse.

\subsubsection{Roteiro das entrevistas}

As entrevistas se iniciavam com uma breve introdução sobre os objetivos do trabalho, e em seguida eram realizadas perguntas objetivas a respeito dos entrevistados, para aferir a capacidade de entendimento dos objetivos propostos. Neste sentido, solicitou-se dos entrevistados, que informassem sua formação acadêmica; cargo que exercia na instituição; idade; e, tempo de trabalho na área financeira, na área de crédito e na instituição propriamente dita. A tabulação dessas informações não faz parte do escopo da pesquisa, somente se deu em razão de aferir sobre a capacidade dos respondentes.

A partir daí, a entrevista seguiu um roteiro com seis etapas de questionamentos na intenção de entender aspectos particulares das instituições, e opiniões pessoais desses profissionais.

Os aspectos analisados envolviam as seguintes indagações:

1) Explicar o processo de concessão de crédito na instituição, especificamente para a área de "Middle-Market".

2) Detalhar o uso de informações advindas das demonstrações contábeis das empresas no processo de concessão de crédito.

3) Informar como a instituição fazia uso de informações compartilhadas (ex. Serasa, Central de Risco do Banco Central) e informações privadas coletadas diretamente dos clientes. 
4) Opinar sobre a influência de aspectos de qualidade, transparência e credibilidade das informações contábeis. De que maneira aspectos como auditoria e o padrão contábil CPC-PME ou IFRS influíam nesses aspectos.

5) Explicar até que ponto aspectos que concernem à melhora das informações contábeis teriam impactos nos riscos, taxas de juros, montantes e prazos nos créditos concedidos e empresas de "Middle-Market".

6) Explicar como a instituição estava preparada para analisar demonstrações contábeis em conformidade com o padrão contábil CPC-PME.

A forma de apresentação das respostas seguiu o modelo de avaliação utilizado por Verrone (2007), em que os argumentos de maior pertinência ao trabalho foram elencados e apresentados conforme frequência com que foram citados nas entrevistas (unanimemente, majoritariamente, raramente, etc.).

\subsubsection{O processo de concessão de crédito}

O primeiro passo das entrevistas foi a obtenção de um panorama geral, sem detalhamentos excessivos, do processo de concessão de crédito, desde a prospecção e captação dos clientes até a aprovação do crédito às empresas.

De maneira geral, a prospecção dos potenciais clientes ficava a cargo de uma área comercial, representada por um ou mais gerentes de relacionamento, e no caso de bancos de varejo, representada pelos gerentes das próprias agências bancárias.

Essa área comercial detinha a responsabilidade de conhecer o cliente e suas necessidades, e em alguns casos, com visita pessoal obrigatória, e uma vez encontrada uma necessidade de crédito, iniciava-se o processo de cadastro e pesquisa do cliente que envolvia desde a documentação cadastral, a análise de restrições por inadimplência e por ações judiciais, a consulta à Central de Risco do Banco Central, até a análise econômico-financeira da empresa, unanimemente.

Algumas vezes esse processo também envolvia a pesquisa sobre informações das pessoas físicas envolvidas nas sociedades das empresas. Um dos entrevistados informou que nesse 
segmento, dependendo da empresa, a figura do sócio poderia ter peso grande na análise, muitas vezes se confundindo com a figura da pessoa jurídica.

Os documentos exigidos para a análise eram, na maioria das vezes, coletados diretamente das instituições que pleiteavam o crédito, ou seja, tinham origem de informações privadas, sem haver a necessidade de se recorrer a publicações para obter a informação.

Uma vez colhida a informação necessária para análise de risco, o processo era encaminhado para uma área especializada de análise. Por vezes essa análise era segmentada dentro do banco conforme o tamanho e/ou região de localização das empresas analisadas.

Nesse segmento, essa análise, na maioria dos casos, tinha características tanto de análise quantitativa (sistemas de 'credit scoring' e modelagem de risco), como de análise julgamental, mas com predominância desta última, em que a função investigativa do analista era mais criteriosa.

Procedimentos como reuniões com as áreas financeiras e contábeis das empresas foram comumente citadas nas rotinas de análise, e alguns entrevistados enfatizaram a importância da visita de crédito, principalmente nas análises das instituições financeiras com foco no atacado. Um dos respondentes comentou que seus profissionais de análise conseguiam através da verificação de aspectos de limpeza de ambiente, do movimento de pessoas nas áreas de faturamento, assim como das condições de estocagem de produtos, aferir melhor se as condições econômicofinanceiras das empresas conferiam com seus aspectos físicos.

Na maioria dos casos, o processo também envolvia aspectos ligados a questões mercadológicas e setoriais, assim como regionais, e em algumas vezes até internacionais.

Bancos de varejo ainda tinham a possibilidade de investigar aspectos relacionados à situação econômico financeira da empresa, com informações de dentro da própria instituição financeira, por meio da movimentação financeira, análise de recebíveis, pagamentos a fornecedores, necessidade de capital de giro, ciclos, prazos, inadimplência, entre outros.

O produto final desta análise era um relatório técnico de crédito, por vezes sistematizado, com diversas denominações (parecer, recomendação, ficha, etc.), o qual apresentava uma 
classificação de risco (rating) da empresa analisada, que é encaminhado para um comitê de aprovação de linha de crédito.

A partir daí, a tesouraria do banco passa a ter condições de precificar os custos das operações de crédito, com base nas necessidades de provisionamento de cada cliente, nas garantias oferecidas para as operações e nos produtos financeiros disponíveis (prazos e montantes), além das condições de mercado naquele momento.

\subsubsection{As informações contábeis e as complementares nas análises de risco}

$\mathrm{Na}$ análise de crédito para o segmento "Middle", verificou-se que, unanimemente, as informações contábeis primárias são sempre solicitadas, e sempre fornecidas pelos clientes. Mesmo que os bancos fizessem uso de informações contábeis terceirizadas, ainda assim a instituição solicitava as informações dos clientes.

Na maioria dos casos, são solicitados das empresas os últimos balanços patrimoniais (com horizonte de dois a três anos anteriores), demonstrações de resultados (DRE) e demonstrações de mutação de patrimônio líquido (DMPL), assim como os balancetes dos últimos 24 meses para verificação da sazonalidade da companhia.

Além disso, é requerido também o preenchimento de fichas cadastrais, envio de declarações de imposto de renda, declarações de faturamento mensal e de abertura de endividamento das empresas. Existe uma preocupação recorrente dos analistas de crédito com operações "offbalance sheet", foram citados como exemplo operações realizadas com empresas de Factoring $^{129}$, e operações com FDIC (Fundos de Direito Creditórios), cujos montantes não são identificados pela Central de Risco do Banco Central, e que por vezes ‘maquiam' os balanços.

Segundo alguns respondentes, esse segmento ainda é pautado de grande informalidade e alto risco, e aspectos que envolvem questões tributárias, muitas vezes prevalecem sobre a realidade econômica das empresas, portanto, é sempre necessário verificar a veracidade das informações com todos os instrumentos possíveis. O processo de relacionamento e verificação

${ }^{129}$ Alienação de direitos creditórios resultantes de vendas mercantis. 
das informações prestadas no passado é de fundamental importância para se construir uma relação de confiança entre a empresa e o banco, o histórico de relacionamento é fator decisivo na análise de risco do segmento.

De maneira geral as informações contábeis servem como norte da análise de crédito. Inclusive, usualmente, são realizados encontros com os responsáveis pelas áreas financeira e contábil das empresas analisadas, para melhor entendimento e verificação de informações contábeis, para depois então realizar os ajustes necessários à análise de riscos.

Entretanto, embora algumas instituições financeiras já coloquem bastante peso nas análises de demonstrações contábeis para formação dos ratings das empresas, alguns bancos ainda as consideram como informação acessória. Um dos respondentes assim comentou: "o banco considera o segmento como de alto risco, portanto prefere colocar mais importância em procedimentos não contábeis, como visitas, informações restritivas, processos judiciais, entre outros, a contabilidade tem peso pouco significativo". Mas, de maneira geral, as informações contábeis fazem parte do processo decisório de crédito, no sentido de que elas são a principal fonte de informações sobre o fluxo de caixa das empresas, segundo palavras de um entrevistado: "que é quem paga as contas no final”.

Informações fornecidas pela Central de risco do Banco Central e informações restritivas sobre inadimplência (Serasa, Boa Vista, etc.), assim como varreduras pelos tribunais de justiça, também foram citados como instrumentos de verificação importantes na análise de crédito das empresas. Essas informações possuem peso determinante, uma vez que são consideradas fontes confiáveis de informação.

Ademais, dois entrevistados de bancos de atacado comentaram que há no mercado de crédito para "Middle-Market", encontros de profissionais das áreas de crédito dos bancos menores, com frequência de pelo menos duas vezes por ano, para trocar informações sobre acontecimentos do mercado, novidades sobre os riscos setoriais e sobre empresas atuantes, são os chamados "informantes". Os bancos costumam ter preferência por empresas que já passaram por análises de crédito criteriosas de outras instituições financeiras no passado. 
No caso dos bancos de varejo, alguns decidiram por terceirizar a manutenção da base de dados contábeis, mas ainda assim solicitam as informações primárias das empresas e possuem total controle sobre seus modelos de atribuição de rating, ou seja, eles decidem a importância que desejam colocar para as informações contábeis.

Para os bancos de atacado, muito comumente, esses processos de terceirização foram citados como processos muito custosos para suas características de porte de instituição financeira.

\subsubsection{A visão sobre a qualidade da informação contábil}

Questionados sobre a qualidade da informação contábil que uma adoção a um padrão contábil internacional no segmento de "Middle-Market" poderia trazer, a maioria das instituições financeiras ainda vê o processo de adaptação como bastante moroso.

Para a maioria, a informalidade ainda está bastante enraizada no segmento, a preocupações quanto à qualidade informacional da contabilidade ainda são incipientes. Três dos entrevistados associaram a qualidade das demonstrações contábeis com realização de trabalhos de auditoria junto a empresas "Big 4", ou com processos de consultoria para melhoria de governança corporativa, considerados pelos respondentes como investimentos em profissionalismo.

No mesmo sentido, outros três respondentes comentaram que já conseguem identificar melhoria das informações contábeis, na medida em que as empresas crescem e ganham em porte.

Diversas preocupações surgiram durante as conversas, um dos entrevistados alertou para os riscos com eventuais gerenciamentos de resultados que uma contabilidade com base no valor justo pode trazer, para ele a contabilidade poderia passar a ter outros fins que não o de simplesmente mostrar a realidade econômica da empresa. As preocupações dos analistas de crédito com critérios de contabilização de ativos e cálculo de depreciação passam a se tornar uma rotina das análises de risco dos bancos, principalmente em um mercado em que o uso de notas explicativas não é tão bem difundido assim. 
Outra instituição é enfática em dizer que nesse segmento boa parte das informações não parte da realidade, elas são produzidas unicamente em função da redução da carga tributária, esse é o incentivo para se produzir a informação contábil no segmento "Middle".

Por outro lado, um dos respondentes diz que já consegue identificar uma mudança no comportamento de alguns empreendedores com relação às informações contábeis. Ele diz que já observa a existência de empresários, que procuram informações sobre a necessidade de aumento de qualidade de demonstrações contábeis, principalmente aqueles que têm em vista oportunidades de negócios, como por exemplo, com fusões e aquisições.

Na visão de outro entrevistado, a adoção de padrão contábil internacional para o segmento "Middle" vai aumentar a credibilidade das informações contábeis, no entanto, ele acredita ser esse um trabalho que envolve anos de contribuição, trata-se de uma construção de longo prazo. Para ele, somente com a construção de um histórico de informação contábil de qualidade, o mercado pode ganhar em com a confiança das instituições.

Quanto ao padrão contábil CPC-PME propriamente dito, os entrevistados na sua grande maioria detinham conhecimento da sua existência, associando o diretamente aos IFRS. No entanto, eles informaram que nesse segmento o referido padrão ainda é incipiente e não está bem difundido. Na opinião dos respondentes, quando uma empresa adota um padrão internacional no "Middle-Market" depende muito do que a auditoria independente sugere para a divulgação das informações contábeis, isso quando têm suas demonstrações auditadas, o que não é um fato tão comum para o segmento. Muitas dessas empresas, inclusive, divulgam suas informações com base no Full IFRS.

Em relação à melhoria da qualidade das informações contábeis por conta do padrão CPC-PME especificamente, um dos entrevistados considera ainda muito cedo para identificar essa melhora, para ele essa percepção somente poderá ser identificada no longo prazo, quando a formação de um histórico de informações permitirá estudar o grau de confiança dos dados divulgados no passado. 


\subsubsection{A visão sobre a relação custo-benefício do padrão contábil}

Embora não se perceba uma grande movimentação em torno das mudanças contábeis no segmento, parte dos entrevistados acredita que o aumento de qualidade da informação contábil pode interferir na redução de custos de captação para o segmento de "Middle-Market", na medida em que os processos de produção de informações das empresas fazem parte dos processos de atribuição de rating, que têm relação direta com o processo de precificação.

Dois bancos de varejo dizem que em seus sistemas de modelagem de atribuição de rating consideram aspectos de qualidade da informação contábil, como relevância, tempestividade e transparência, um deles inclusive informou que suas metodologias de análise usadas nos cálculos de riscos sofreram revisões em função das mudanças contábeis, há influência tanto na análise julgamental quanto na análise automatizada produzida pelos sistemas de escore.

Outro banco de varejo, diz claramente que premia a utilização do padrão contábil internacional para efeito de rating, desde que as comparações com as demonstrações anteriores sejam bem evidenciadas. No fundo ele está premiando uma melhor informação.

Os bancos de atacado em geral são mais prudentes, e ainda não está muito claro para eles que essa qualidade da informação contábil possa trazer consigo uma redução do custo de crédito. Um deles diz que tem dificuldades de enxergar as duas coisas nesse segmento, tanto a melhora na qualidade da contabilidade, quanto sua associação com uma redução de custos.

Outras duas instituições financeiras com foco no "Middle", dizem que se de fato aumentar a qualidade da informação contábil no segmento, esse aumento será pequeno e gradual, os riscos desse segmento ainda são muito altos, e a consolidação da transparência para médias empresas ainda está distante.

Uma observação relevante foi feita por outro banco de varejo, embora ele acredite que uma maior qualidade da informação contábil possa se traduzir em melhores taxas de juros, dependendo do tamanho das instituições, os custos com evidenciação em um novo padrão e investimentos em sistemas de informação podem ser superiores aos benefícios trazidos com as taxas. Em sua opinião, a recepção de um padrão contábil deveria ser voluntária e não obrigatória. 


\subsubsection{Aspectos sobre educação contábil nas instituições financeiras}

A maioria das instituições se diz preparada para analisar demonstrações contábeis no novo padrão internacional. Em geral, houve investimento em treinamento em IFRS para os analistas e gerentes de crédito, muitas vezes realizados de forma obrigatória, on-line, via sistema de ensino à distância, e em alguns casos, também para os gerentes comerciais. Além dos incentivos que normalmente as instituições fornecem a seus colaboradores para atualização em ensino de pós-graduação.

Outra instituição financeira diz que o aprendizado vem ocorrendo na prática, a partir do contato com contadores de empresas e auditorias, e com a contratação de jovens analistas com formação em IFRS. Essa mesma instituição aponta sua área de crédito como formadora de talentos para o mercado.

Outro respondente diz que procurou atualização de seus colaboradores com instituições de ensino que privilegiassem o aprendizado voltado para o mercado, para ele a análise baseada nos cinco C's do crédito é coisa do passado, que precisa ser urgentemente revista.

No entanto ainda há instituições ainda em fase de adaptação aos novos critérios contábeis. Outro banco, diz não houve qualquer preparação dos seus analistas de crédito quanto aos novos padrões contábeis, segundo seu gestor, essa preparação não está na lista de prioridades do banco. 


\section{CONCLUSÕES}

Esta pesquisa examinou a relação entre a adoção de um padrão contábil internacional pelas pequenas e médias empresas, associando-a com uma melhora na qualidade da informação contábil, e o custo de crédito concedido pelas instituições financeiras. O objetivo principal do trabalho foi investigar se adoção do padrão contábil internacional provocou efeito no custo de crédito bancário.

A pesquisa procurou identificar qual era a relação entre a adoção do padrão contábil internacional para pequenas e médias empresas (CPC-PME) no Brasil e o custo do crédito concedido pelas instituições financeiras. $\mathrm{O}$ trabalho se apoiou em duas hipóteses calcadas no referencial teórico, com base na teoria da divulgação e nos objetivos propostos pelos reguladores, que associavam a adoção de padrões contábeis internacionais e/ou uma melhora da qualidade da informação contábil com redução nos custos de captação bancária para empresas de porte reduzido.

Como objetivo secundário, foi observada a prática de algumas empresas de pequeno e médio porte no Brasil nos critérios de divulgação de suas demonstrações contábeis, para visualizar o atual estágio de implementação da CPC-PME no país, assim como se investigou como as instituições financeiras no mercado brasileiro levam em consideração as informações contábeis de pequenas e médias empresas no momento da análise de concessão de crédito.

\subsection{Resumo das evidências encontradas}

Em relação ao padrão contábil CPC-PME propriamente dito, pôde-se notar pela análise descritiva da amostra de empresas analisadas que a adoção deste padrão contábil ainda é muito incipiente. Embora seja obrigatório, apenas $11 \%$ em média do total da amostra adotou este padrão nos dois anos de vigência da norma. Por outro lado, uma grata surpresa foi a percepção de uma utilização de padrões contábeis com base no CPC, com normas baseadas em princípios, indicando que padrões contábeis internacionais já fazem parte da rotina de parte das empresas de médio porte desde 2009.

Da amostra inicial coletada, percebe-se uma parcela das empresas no âmbito das PMEs ainda com características de aversão ao risco, já que $24 \%$ das empresas da amostra não possuía 
qualquer tipo de dívida em instituições financeiras em algum dos três anos analisados. Muitas empresas preferem se financiar de outras maneiras que não no mercado de crédito bancário. A razão desta característica não foi explorada neste trabalho, se por motivos de dificuldade de acesso ao crédito ou de possuírem cultura empresarial de aversão ao risco.

Das análises quantitativas realizadas com as empresas que se financiavam no mercado de crédito bancário, os resultados apontaram para uma relação inversa ainda muito incipiente entre custo de crédito e qualidade da divulgação contábil, que ainda carece de consistência no tempo e no espaço (setorial e regional). Mas as hipóteses não foram totalmente rejeitadas.

Os testes de média resultaram em diferenciações entre grupos de divulgação contábil no que se referem aos custos de captação que não podem ser consideradas desprezíveis, as quais se demonstraram estatisticamente significativas. Embora, não houvesse na maioria dos casos repetição de resultados entre os anos analisados, apresentando inconsistência no tempo, percebe-se que, em alguns casos, dependendo do setor, região ou ano, as hipóteses não foram rejeitadas. Os resultados vêm ao encontro das informações colhidas das entrevistas, na medida em que fatores mercadológicos (regionais e setoriais) são levados em conta no momento da concessão de crédito e que informações contábeis fazem parte do processo de concessão de crédito, em pesos diferentes para cada instituição financeira.

Os destaques ficam para a Região Sul do país, a única segregação, entre as divisões setoriais e regionais realizadas, que apresentou consistência de resultados entre os dois anos analisados para o índice de despesas financeiras líquidas sobre o passivo financeiro $\left(\mathrm{I}_{1}\right)$, para a hipótese I, para diferentes grupos de nível de disclosure; e para o setor de Indústria de Base, que apresentou significância estatística para seis dos 12 testes não paramétricos realizados, sendo três em 2010 e três em 2011, para ambas as hipóteses ( $\mathrm{H}_{\mathrm{I}}$ e $\left.\mathrm{H}_{\mathrm{II}}\right)$, englobando todos os índices $\left(\mathrm{I}_{1}, \mathrm{I}_{2}\right.$ e $\left.\mathrm{I}_{3}\right)$, embora os resultados não apresentassem repetição entre os anos.

A análise de dados em painel, por sua vez, descartou qualquer significância estatística dos relacionamentos referentes à divulgação contábil (disclosure e evidenciação do padrão contábil CPC). No entanto, as relações das demais variáveis apresentaram significância estatística, e principalmente no que tange a relação com a variável Dbig4, representativa de revisão das demonstrações contábeis por empresas de auditoria reconhecidas como 'Big Four', houve indicação de que informações contábeis em que o mercado de crédito coloca relativa confiança 
influem na determinação dos custos de captação. Esta percepção também foi identificada nas entrevistas com as instituições financeiras.

Da análise qualitativa, percebe-se claramente a predominância de um ambiente de riscos altos, em que a divulgação, embora esteja sempre presente no processo de avaliação de risco, seja apenas um dos diversos instrumentos de mitigação de incertezas usados pelas instituições financeiras. Pelas respostas dos gestores das instituições financeiras entrevistados, participantes do mercado de crédito para o segmento, identificou-se que os processos de concessão de crédito são bastante criteriosos em relação ao risco. O alto risco de fraudes foi citado com bastante frequência pelos bancos neste segmento da economia.

Neste sentido, a melhora na divulgação das informações contábeis poderia vir a ajudar tanto a ponta tomadora de crédito, as empresas de porte reduzido, quanto a ponta tomadora de risco, os bancos. Mas se percebe que este ainda é um ambiente em fase de construção, e, caso se desenvolva, deverá trazer benefícios no longo prazo.

Se por um lado o mercado de crédito vê com bons olhos o aumento da divulgação de informações contábeis, as perspectivas de mudança em relação à adoção de um novo critério de padrão contábil internacional por pequenas de menor porte ainda são duvidosas.

Outro ponto interessante investigado trata da questão da obrigatoriedade da norma para pequenas e médias empresas, os custos com adaptação ao novo padrão (pessoal qualificado, sistemas, processos, etc.) podem ser muito heterogêneos entre as empresas deste setor, ou seja, o que é pouco para algumas, pode ser muito para outras.

A adoção do padrão contábil internacional, na opinião de alguns bancos, assim como deste autor, deveria ser voluntária, dependendo da análise de custo-benefício que as próprias empresas iriam fazer na medida em que elas percebessem ganhos com a divulgação de informações.

A principal contribuição deste trabalho é o exame da relação entre a qualidade das informações contábeis e o custo do crédito bancário, no âmbito das empresas de porte reduzido, assunto vagamente explorado no meio acadêmico. A pequena influência das informações con- 
tábeis nesse segmento, pelo menos nesse primeiro momento de mudanças nos padrões contábeis, no custo de crédito bancário, contribui para explicar o alto grau de informalidade nas PMEs.

\subsection{Implicações para os usuários da informação}

Os resultados da análises quantitativas, somadas às percepções encontradas na análise qualitativa, relacionadas aos reflexos no custo de crédito bancário, podem ser úteis para diversos interessados:

- Analistas de crédito - este é o grupo de usuários com maior importância no âmbito do segmento de empresas estudadas nesta pesquisa. Se a informação é útil na medida em que serve para tomada de decisões, aqui ela aparece na forma de determinação de classificações de rating, que por sua vez, influem nos custos de captação bancária. De maneira geral, diante da análise qualitativa formada com base nas entrevistas realizadas, fica evidente uma latente preocupação com riscos no segmento de "Middle-Market", também explicadas pelo alto grau de informalidade do setor. Dificilmente os processos de concessão de crédito sofrerão mudanças diante da adoção de um novo padrão contábil pelas empresas, pelo menos em curto prazo. O pouco tempo de maturação das normas internacionais, principalmente no que se referem às PMEs, não permite uma contribuição decisiva da contabilidade nos processos de decisão como ocorre com grandes empresas. As instituições financeiras continuarão a buscar o maior número de fontes de informação possíveis para se certificar da confiabilidade dos dados contábeis fornecidos pelas empresas. Por outro lado, como já se percebe que em alguns casos, pode ocorrer uma diferenciação de grupos de nível de disclosure e evidenciação de padrão contábil, como determinantes para os custos de crédito bancário, ou seja, à medida que as empresas se adaptem ao novo padrão internacional, essa informação pode começar a pesar, pelo menos indiretamente, nos custos de crédito bancário, fato percebido diante da consideração de aspectos sobre a qualidade das informações contábeis nos sistemas de geração de classificação de rating utilizados pelos bancos. 
- Reguladores - os resultados confirmam que, em alguns casos, para as empresas de médio porte analisadas, pode haver uma melhora em termos de custo de captação bancária, conforme um dos argumentos em que o IASB se apoiou na concepção da IFRS for SMEs. No entanto, os resultados ainda não são consistentes no tempo, pelo menos considerando o curto espaço de tempo estudado de dois anos neste trabalho. O que se questiona no caso brasileiro é a obrigatoriedade do padrão CPC-PME para certo grupo de empresas fundamentado nesse custo de captação, o que ocorre se a empresa não fizer uso de recursos de terceiros, especificamente de instituições financeiras? A norma deveria ser repensada, da mesma forma que foi feito com o caso das microempresas e empresas de pequeno porte ${ }^{130}$ com o advento da Resolução CFC 1.418/12, que admite uma forma de contabilização mais simplificada, condizente com o porte dessas entidades. O mesmo raciocínio se faz para a relação de custo-benefício, não existem estudos que comprovem que os benefícios advindos com a adoção do padrão contábil internacional superam os custos de divulgação (pessoal qualificado, sistemas, processos, etc.). Uma forma de adaptar os padrões contábeis às necessidades das empresas seria permitir que os padrões contábeis fossem adotados voluntariamente por elas, do mesmo jeito, que, por exemplo, uma empresa divulga suas demonstrações contábeis baseadas no CPC completo sem a necessidade explícita na Lei, ou seja, essa empresa em algum momento deve ter avaliado que deveria ter benefícios com esse tipo de divulgação. Também é importante ressaltar que embora as empresas estudadas na pesquisa sejam obrigadas a preparar suas demonstrações contábeis com base no CPC desde 2010, parte considerável da amostra investigada não vem cumprindo as determinações regulamentares do CFC (47\% em 2010, 40\% em 2011).

- Empreendedores - este grupo de usuários pode identificar na divulgação de informações contábeis de qualidade, uma fonte de diversificação das fontes de recursos de investimento, e não simplesmente vê-la como parte de suas obrigações fiscais e um 'peso' para seus negócios. Na medida em que os fornecedores de crédito bancário, ou mesmo novos empreendedores, sinalizarem para a utilidade

${ }^{130}$ Conforme Lei Complementar 123/06. 
das informações de qualidade, com base em uma situação financeira que represente a realidade econômica das empresas, tanto para a concessão de créditos em melhores condições, como para a abertura das empresas para novas oportunidades de negócio, tanto no âmbito nacional como também internacional, o padrão contábil internacional não só poderá ser requisitado, como também preferido aos demais. A pesquisa indica que, em empresas com maior tamanho em receita, os benefícios em custos de captação bancários ficam mais evidentes. Somente é preciso analisar, diante de suas estruturas de capital e de suas perspectivas de crescimento das PMEs, se esse investimento em informação contábil pode ser traduzir em ganhos futuros para a empresa. Por outro lado, se uma empresa ainda não atingiu um patamar de planejamento de desenvolvimento com vistas ao longo prazo, é evidente que o investimento em informação fica em segundo plano, o que é perfeitamente compreensível, e o grau de formalidade fica prejudicado.

\subsection{Limitações da pesquisa}

Quando são realizados trabalhos envolvendo esse tipo de entidade, há uma dificuldade comum: a unicidade de critérios utilizados para definição da taxonomia empregada para empresas de pequeno e médio porte, ou seja, existe uma heterogeneidade de classificações que fazem com que nem sempre os trabalhos realizados tenham o mesmo objeto de estudo. Decidiuse por não se restringir e ter como objeto de estudo todas as empresas que estão abarcadas pelo conceito contábil de PME conforme a definição do IASB.

Além do mais, existe a própria questão de se envolver referência ao porte das entidades, pois no caso dos Estados Unidos, por exemplo, a empresa de pequeno porte referida na norma é aquela por eles chamada de entidade privada, isto é, empresas sem ações negociadas no mercado acionário.

No mais, por questão de incipiência de estudos realizados com abordagem referente à temática e da quase inexistência de dados primários para realização de pesquisas, no caso das demonstrações financeiras de PMEs, foi necessário estabelecer uma amostra não probabilística que não necessariamente se identifica com todo o universo de empresas estudadas. 
Além de restringir a quantidade de dados contábeis a determinadas empresas que divulgaram seus dados ao Anuário Melhores e Maiores, em razão da novidade do CPC-PME, em vigor desde 2010, foram coletados dados referentes somente a três anos de divulgação, e como análise se faz sobre a influência da informação contábil de um ano nos efeitos em custos de crédito do ano seguinte, a amostra nos dá apenas dois graus de liberdade.

Ademais, o mesmo critério foi utilizado para a escolha das instituições financeiras a serem entrevistadas, amostra não probabilística de instituições financeiras que usualmente concedem crédito a empresas do "Midlle-Market". Existe a fragilidade na escolha do critério de seleção da amostra, no entanto nesse caso, a amostra se apresenta bastante representativa, na medida em que corresponde a instituições financeiras que concederam mais de $80 \%$ do crédito a médias empresas, entre as maiores instituições bancárias em crédito para o setor no Brasil.

No que se refere à qualidade da coleta de informações contábeis, embora Brito (2010, p.88) tenha alertado para o fato de que valores contábeis de despesas financeiras podem conter vieses tanto por contabilização de outras despesas que não são relacionadas a dívidas bancárias (ex. juros sobre capital próprio, juros pagos a fornecedores, descontos concedidos), optou-se por utilizá-los por questão de simplificação da coleta de dados.

Além disso, no Brasil há uma participação considerável nas operações de crédito em recursos direcionados que não necessariamente seguem a mesma dinâmica de negociação de juros que as operações com recursos livres. O levantamento dos dados contábeis não diferenciou a natureza dos recursos.

Enfim, como o trabalho se refere a pequenas e médias empresas, e existe uma maior dificuldade em se obter a abertura dessas informações nas demonstrações contábeis e notas explicativas, a necessidade de viabilização da pesquisa nos remeteu à simplificação da coleta por dados, sabendo-se das limitações existentes.

Em relação à divisão geográfica utilizada, no moldes da segregação realizada pela Melhores e Maiores, é importante deixar claro que o critério levado em conta foi a localização da matriz da empresa analisada, e não necessariamente o mercado em que empresa atua é aquele em que se localiza sua sede. Também há fragilidade com relação ao agrupamento de setores de atuação econômica utilizados para simplificação da análise, uma vez que que adotou-se um 
critério de classificação por semelhança entre empresas de um setor macro, que não necessariamente se comportam da mesma forma com relação às variáveis estudadas.

No que se referem aos testes estatísticos na análise de dados em painel, também para efeito de simplificação, assumiu-se que as relações entre as variáveis estudadas possuíam características exógenas, ou seja, as diferenciações de tipos de gestão entre as empresas foram tomadas como não significativas.

Quanto aos resultados da análise de dados em painel, a estimação mais eficiente, com menor variância, seria aquela com estimadores de efeitos fixos. No entanto a violação do pressuposto da normalidade a tornou inutilizável. Assim, foram utilizados para análise os estimadores POLS, que embora não sejam os mais eficientes, são consistentes.

\subsection{Sugestões para estudos futuros}

Esse trabalho poderá ser estendido na medida em que seja possível coletar mais informações contábeis ao longo dos anos, e os padrões contábeis estejam cada vez mais consolidados e difundidos entre as empresas. Os resultados encontrados na pesquisa apontaram para a necessidade de estudos com maior abrangência de anos sob o novo padrão contábil.

Por outro lado, poder-se-ia investigar as próprias empresas de porte reduzido mais qualitativamente, na tentativa de entender mais a fundo as características de seus custos com informação. Uma sugestão seria avaliar como as mudanças se deram nas empresas que prestam os serviços de contabilidade para essas empresas.

Estudos empíricos com empresas ainda menores, como microempresas e empresas de pequeno porte, retiradas da amostra da pesquisa, por questão de viabilidade, também seriam bem-vindos. 


\section{REFERÊNCIAS}

Albuquerque, K. S. L. S.; Dias Filho, J. M. \& Silva, F. D. C. (2010). Auditoria e custo de capital de terceiros: estudo empírico sobre o custo dos financiamentos bancários nas empresas brasileiras de capital aberto auditadas pelas big four e demais firmas de auditoria. Revista de contabilidade da UFBA. 4(3), 65-78.

BANCO CENTRAL DO BRASIL (2011). Relatório de inclusão financeira. (2a. ed.). Brasília, DF: BCB, Recuperado em 5 de novembro de 2012, de http://www.bcb.gov.br/Nor/relincfin/RIF2011.pdf.

Barbe, O. \& Didelot, L. (2010, mar). Comptes individuels en norme IFRS pour PME: réalisme ou utopie. Revue Française de Comptabilité. 430, 32-38.

Beaver, W. H. (1998). Financial reporting: an accounting revolution. (3rd ed.). Prentice-Hall (Contemporary Topics in Accounting Series): New Jersey, NY, 1998.

Bedê, M. A. (2004). Gargalos no financiamento dos pequenos negócios no Brasil. In: C. A. Santos (Org.), SEBRAE, Sistema Financeiro e as micro e pequenas empresas: diagnósticos e perspectivas. (2a. ed., pp. 46-57). Brasília, DF: SEBRAE

Bertoni, M. \& De Rosa, B. (2010). The evolution of financial reporting for private entities in the European Union. Social Science Research Network. Recuperado em 03 de agosto de 2011, de http://papers.ssrn.com/sol3/papers.cfm?abstract_id=1536065

Bessieux-Ollier, C. \& Walliser, E. (2012). Why firms listed on an unregulated financial market comply voluntarily with IFRS: an empirical analysis with French data. Comptabilités et innovation. Grenoble, França. Recuperado em 5 de novembro de 2012, de http://econpapers.repec.org/scripts/redir.pf?u=http\%3A\%2F\%2Fhal.archives-ouvertes.fr\%2Fdocs\%2F00\%2F69\%2F09\%2F35\%2FPDF\%2F415_BessieuxOllier_Walliser.pdf;h=repec:hal:journl:hal-00690935.

Beuren, I. M. (Org.). (2010). Como elaborar trabalhos monográficos em contabilidade: teoria e prática (3a. ed., 5a. reimpr.). São Paulo: Atlas. 
Brito, G. A. S. (2010). Conservadorismo contábil e o custo de crédito no Brasil. Tese de Doutorado, FEA/USP. Universidade de São Paulo. São Paulo.

Cardoso, R. L., Saravia, E., Tenório, F. G., \& Silva, M. A. (2009, julho/agosto). Regulação da contabilidade: teorias e análise da convergência dos padrões contábeis aos IFRS. rap Revista de Administração Pública - Rio de Janeiro, 43(4), 773-799.

Carmo, C. H. S., Ribeiro, A. M., \& Carvalho, L. N. (2011, setembro/dezembro). Convergência de fato ou de direito? A influência do sistema jurídico na aceitação das normas internacionais para pequenas e médias empresas. Revista de Contabilidade e Finanças - USP, 22(57), 242-262.

Carvalho, C. E. \& Abramovay, R. (2004). O difícil e custoso acesso ao sistema financeiro. In: C. A. Santos (Org.) SEBRAE, Sistema Financeiro e as micro e pequenas empresas: diagnósticos e perspectivas (2a. ed., pp.17-45) Brasília: SEBRAE.

Carvalho, L. N. \& Iudícibus, S. (2001, maio). Porque devemos ousar em contabilidade? Boletim do Ibracon.

Chen, F., Hope, O., Li, Q. \& Wang, X. (2010, december). Financial reporting quality and investment efficiency of private firms in emerging markets. Accounting Review. Recuperado em $1^{\circ}$. de julho de 2011, de http://ssrn.com/abstract=1722804.

CONSELHO FEDERAL DE CONTABILIDADE (2010). Contabilidade para pequenas e médias empresas: Normas Brasileiras de Contabilidade NBC T 19.41. Brasília, DF: CFC.

CONSELHO FEDERAL DE CONTABILIDADE (2012, 5 de dezembro). Resolução CFC 1.418/12. Aprova a ITG 1000 - Modelo contábil para microempresa e empresas de pequeno porte. Brasília, DF: CFC.

COMITÊ DE PRONUNCIAMENTOS CONTÁBEIS (2009). Interpretações e orientações técnicas contábeis. Brasília, DF: CFC. 
Christie, N., Brozovsky, J. \& Hicks, S. (2010, july). Accounting for small businesses: the role of IFRS. The CPA Journal, 40-43.

Dantas, J. A., Zendersky, H. C., Santos, S. C. \& Niyama, J. K. (2005, dezembro). A dualidade entre os benefícios do disclosure e a relutância das organizações em aumentar o grau de evidenciação. Revista Economia \& Gestão, 5(11), 56-76. doi:10.5752/40

Dantas, J. A., Rodrigues, F. F., Niyama, J. K. \& Mendes, P. C. M. (2010, maio/agosto). Normatização contábil baseada em princípios ou em regras? Benefícios, custos, oportunidades e riscos. $R C O$ - Revista de Contabilidade e Organizações - FEA-RP/USP, 4(9), 7-29.

Daske, H.; Hail, L.; Leuz, C. \& Verdi, R. S. (2008). Mandatory IFRS reporting around the world: early evidence on the economic consequences. Journal of Accounting Research. 45(5). Recuperado em 18 de março de 2013, de http://onlinelibrary.wiley.com/doi/10.1111/j.1475-679X.2008.00306.x/pdf.

Daske, H., Hail, L., Leuz, C. \& Verdi, R. S. (2013). Adopting a label: heterogeneity in the economic consequences around IAS/IFRS adoptions. Social Science Research Network. Recuperado em 18 de março de 2013, de http://ssrn.com/abstract=1864771

DELOITTE. (2009). Eficiência nos novos tempos da economia: Um estudo sobre as pequenas e médias empresas que mais crescem no Brasil. Recuperado em 7 de julho de 2011, de http://www.deloitte.com/assets/DcomBrazil/Local\%20Assets/Documents/Relatorio\%20PME\%20Deloitte\%202009.pdf.

DELOITTE. (2010). IFRS para PMEs ao seu alcance - 2010. Recuperado em 7 de julho de 2011, de http://www.deloitte.com.br/publicacoes/2007/Pocket_PME.pdf.

DELOITTE. (2012a). As PMEs que mais crescem no Brasil: um estudo sobre os desafios do ambiente de negócios no caminho das empresas emergentes. 2012. Recuperado em 2 de novembro de 2012, de http://www.deloitte.com/view/pt_BR/br/Conteudos/estudosepesquisas/PMEs/fb77f28e20bb9310Vgn VCM1000001a56f00aRCRD.htm Acesso em 2/11/2012. 
DELOITTE. (2012b) IFRS para PMEs ao seu alcance - 2012. Recuperado em 5 de novembro de 2012, de http://www.deloitte.com/assets/Dcom-Br azil/Local\%20Assets/Documents/Servi\%C3\%A7os/IFRS/IFRS\%20para\%20PMEs\%20ao\%20seu\%20alcance\%2 02012.pdf

DIEESE. (2012, abril). Nota Técnica - Spread e juros bancários. n. 109. Recuperado em 7 de novembro de 2012, de http://www.dieese.org.br/notatecnica/notaTec109Spread.pdf

EXAME. (2012, julho). Melhores \& Maiores: As 1000 maiores empresas do Brasil. Exame. São Paulo: Ed. Abril.

Fávero, L. P., Belfiore, P., Silva, F. L., Chan, B. L. (2009). Análise de dados: modelagem multivariada para tomada de decisões. Rio de Janeiro: Elsevier.

FEDERAL RESERVE BANK OF SAINT LOUIS (2013, fevereiro). Economic Research Household Debt to GDP for United States. Recuperado em 28 de fevereiro de 2013, http://research.stlouisfed.org/fred2/series/HDTGPDUSQ163N.

Fernandes, E. N. L. (2010). O impacto da informação contábil de empresas fechadas na percepção de risco dos analistas de crédito. Dissertação de Mestrado, FEA/USP, Universidade de São Paulo, São Paulo.

Ferraro, C. \& Goldstein, E. (2011). Políticas de acceso al financiamiento para las pequeñas y medianas empresas en América Latina. In: Eliminando barreras: El financiamiento a las pymes en América Latina. Ferraro, C. (Coord.). CEPAL, Colección Documentos de Proyectos. 9-59.

Fitzpatrick, M. \& Frank, F. (2009, december). IFRS for SMEs: the next standard for U.S. private companies. Journal of Accountancy, 208(6) 50-54.

Floriano, D. E. (2010). O grau de internacionalização, as competências e o desempenho da PME brasileira. Tese de Doutorado, FEA/USP. Universidade de São Paulo. São Paulo. 
Girotto, M. (2010, novembro/dezembro). Brasil começa a adotar o IFRS na contabilidade de PMEs [Reportagem]. Revista Brasileira de Contabilidade, 186, 7-23.

Godoi, C. K., Bandeira-de-Mello, R. \& Silva, A. B. (Org.). (2006). Pesquisa qualitativa em estudos organizacionais: paradigmas, estratégias e métodos. São Paulo: Saraiva.

Hendriksen, E. S. \& Van Breda, M. F. (2010). Teoria da contabilidade. (A. Z. Sanvicente, trad., 5a. ed. Americana). São Paulo: Atlas.

Herman, N. (2010, december). IFRS for SMEs: not for private American companies. The CPA Journal. 11-12.

Hope, O. K., Thomas, W. B., \& Vyas, D. (2009). Transparency, ownership, and financing constraints in private firms. Working paper, University of Toronto and University of Oklahoma. Recuperado em $1^{\text {o }}$. de julho de 2011, de http://centerforpbbefr.rutgers.edu/20thfea/accountingpapers/session8/hope,\%20thomas, \%20and\%20vyas.pdf.

INSTITUTO BRASILEIRO DE GEOGRAFIA E ESTATÍSTICA (IBGE). (2003). As micro e pequenas empresas comerciais e de serviços no Brasil 2001. Estudos e Pesquisas. Informação Econômica No.1. Rio de Janeiro: IBGE.

INSTITUTO BRASILEIRO DE GEOGRAFIA E ESTATÍSTICA (IBGE). (2012). Estatísticas do cadastro central de empresas 2010. Rio de Janeiro: IBGE.

INSTITUTO DOS AUDITORES INDEPENDENTES DO BRASIL (IBRACON). (2010). Bases para conclusões da norma internacional de relatório financeiro para pequenas $e$ médias empresas (IFRS para PMEs), (IFRS for SMEs (IASB), trad.).

INTERNATIONAL ACCOUNTING STANDARDS BOARD (IASB). (2004). Preliminary views on accounting standards for small and medium-sized entities. London.

INTERNATIONAL ACCOUNTING STANDARDS BOARD (IASB). (2007). Basis for conclusions on exposure draft: IFRS for small and medium-sized Entities. London. 
INTERNATIONAL ACCOUNTING STANDARDS BOARD (IASB). (2009). Basis for conclusions on IFRS for small and medium-sized Entities. London.

Iudícibus, S. (2000). Teoria da contabilidade. (6a. ed.) São Paulo: Atlas.

Iudícibus, S. \& Lopes, A. B. (Coord.). (2004). Teoria avançada da contabilidade. (1a. ed.) São Paulo: Atlas.

Iudícibus, S., Martins, E., Gelbcke, E. R. \& Santos, A. (2010). Manual de contabilidade societária. FIPECAFI - Fundação Instituto de Pesquisas Contábeis, Atuariais e Financeiras, FEA/USP. São Paulo: Atlas.

Jermakowicz, E. K. \& Epstein, B. J. (2010, spring). IFRS for SMEs - an option for U.S. private entities? Review of Business. (Special Issue: Accounting). 30(2), 72-79.

Kamnikar, J. A., Kamnikar, E. G. \& Burrowes, A. (2012, january). One size does not fit all. Journal of Accountancy, 213(1) 46-49.

Kassai, J. R. \& Casa Nova, S. P. C. (2006, 1º semestre). Pequenas empresas: como é difícil "levantar dinheiro"!. ConTexto, 6 (9).

Kassai, J. R. \& Kassai, S. (2001). Balanço perguntado: solução para as pequenas empresas. In VIII Congresso Brasileiro de Custos, São Leopoldo/RS.

Kassai, S. (1997, janeiro/junho). As empresas de pequeno porte e a contabilidade. Caderno de Estudos, FIPECAFI, 9(15), 60-74.

Lambert, R.; Leuz, C. \& Verrecchia R. E. (2007, may) Accounting Information, Disclosure, and the Cost of Capital. Journal of Accounting Research, 45(2), 385-420.

Lei n. 11.638, de 28 de dezembro de 2007. (2007, 28 de dezembro). Diário Oficial da União. Brasília, DF. 
Lei Complementar n. 123, de 14 de dezembro de 2006. (2006, 14 de dezembro). Estatuto Nacional da microempresa e da empresa de pequeno porte. Diário Oficial da União. Brasília, DF.

Lenormand, G., Poulard, B. \& Touchais, L. (2012). Les IAS/IFRS: bilan et perspective. Revue Française de Gestion. (222), 55-66.

Lima, G. A. S. F. (2007). Utilização da teoria da divulgação para avaliação da relação do nível de disclosure com o custo da dívida das empresas brasileiras. Tese de Doutorado, FEA/USP, Universidade de São Paulo, São Paulo.

Litjens, R., Bissessur, S., Langendijk, H. \& Vergoossen, R. (2012, march). How do preparers perceive costs and benefits of IFRS for SMEs? Empirical evidence from the Netherlands. Accounting in Europe, 1-31.

Lo Russo, R. (2010, septembre/decembre). Où em est-on avec le projet de l'IASB de norme IFRS adapté pour les PMEs? La Revue des Sciences de Gestion: Directions et Gestion, 45(245/246), 141-148.

Lopes, A. B. \& Martins, E. (2005). Teoria da contabilidade: uma nova abordagem. São Paulo: Atlas.

Lopes, P. T. \& Rodrigues, L. L. (2007). Accounting for financial instruments: An analysis of the determinants of disclosure in the Portuguese stock exchange. The International Journal of Accounting, 42, 25-56.

Malhotra, M., Chen, Y., Criscuolo, A., Fan, Q., Hamel, I. I. \& Savchenko, Y. (2007, may). Expanding access to finance: good practices and policies for micro, small, and medium enterprises. The World Bank Institute (WBI Learning Resource Series): Washington.

Martins, E., Diniz, J. A. \& Miranda, J. G. (2012). Análise avançada das demonstrações contábeis: uma abordagem crítica. São Paulo: Atlas. 
Martins, G. A. \& Theóphilo, C. R. (2009). Metodologia da investigação científica para ciências sociais aplicadas. (2a. ed.) São Paulo: Atlas.

Masca, E. \& Gall, J. (2008, march). Aspects regarding IFRS' application to SMEs. In 2nd WSEAS International Conference on Management, Marketing and Finances (MMF'08), Harvard, Massachusetts, 80-84. Recuperado em 2 de julho de 2011, de http://www.wseas.us/e-library/conferences/2008/ harvard/mmf/11-608-150.pdf.

Meirelles, G. (2012, 31 de outubro). Adoção do padrão IFRS anda a passos lentos entre PMES. Valor econômico, São Paulo, pp. 8-9 (F).

Morais, J. M. (2005, novembro). Crédito Bancário no Brasil: Participação das pequenas empresas condições de acesso. Proyecto Regional sobre "Movilización de los recursos locales mediante el microcrédito y oportunidades para la gestión de servicios urbanos", CEPAL-Gobierno de Italia: Brasília, DF.

Murcia, F. D.; Santos, A. (2009, maio/agosto). Regulação contábil e a divulgação de informações de operações com instrumentos financeiros derivativos: análise do impacto da CVM No. 566/08 e da CVM No. 475/08 no disclosure das companhias abertas no Brasil. RCO - Revista de Contabilidade e Organizações - FEARP/SP, 3(6), 3-21.

Nobre, L. H. N.; Câmara, S. F. \& Guimarães Jr., F. R. F. (2006). Os níveis de endividamento das pequenas e médias empresas brasileiras são determinados por sua estrutura de capital? In Anais do XXVI Encontro Nacional de Engenharia de Produção (ENEGEP), Fortaleza/CE. Recuperado em 18 de março de 2013, de http://www.abepro.org.br/publicacoes/index.asp?pchave $=$ endividamento $\& a n o=2006 \& x=25 \& y=5$.

Pacter, P. (2007, october). Should U.S. private companies use IFRS for SMEs? Financial Executive. 23(8), 16-17.

Pacter, P. (2008, october). An IFRS for private entities. International Journal of Disclosure and Governance. 6(1), 4-20. 
Pacter, P. (2009, september). IFRS for most private companies goes live. Financial Executive, 25(7), 28-30.

Pacter, P. (2010). Overview of the IFRS for SMEs. IASC Foundation [Webcast]. Recuperado em $1^{\circ}$. de julho de 2011, de <http://web.worldbank.org/WBSITE/EXTERNAL/ COUNTRIES/ECAEXT/EXTCENFINREPREF/0,,contentMDK:22617169 page PK:64168445 piPK:64168309 theSitePK:4152118,00.html>.

Pereira, G. (2011, março). Tudo certo para aderir a balanço mais transparente? Revista Exame PME. (34). Recuperado em 3 de dezembro de 2012, de http://exame.abril.com.br/revista-exame-pme/edicoes/0034/noticias/manobras-contabeis?page=1.

Prudêncio, C. \& Salotti, B. M. (2007). A Importância das Demonstrações Contábeis na Análise de Crédito das Pequenas e Micro Empresas Brasileiras. In: X SEMEAD (Seminários em Administração), São Paulo.

Resolução 3.721, de 30 de abril de 2009 (2009, 30 de abril). Dispõe sobre a implementação de estrutura de gerenciamento de risco de crédito. Diário Oficial da União. Brasília, DF.

Ross, E. S. (2010). Estratégia de Relacionamento dos Bancos com as Pequenas Empresas. Dissertação de Mestrado, FEA/USP, Universidade de São Paulo, São Paulo, Brasil.

Salotti, B. M. (2005). Divulgação voluntária das demonstrações de fluxo de caixa no mercado de capitais brasileiro. Tese de Doutorado, FEA/USP, Universidade de São Paulo, São Paulo, Brasil.

Schiebel, A. (2007). Is there a solid empirical foundation for the IASB's draft IFRS for SMEs? In: Annual Financial Reporting and Business Communication Conference (5-6 July 2007, Cardiff Business School). Recuperado em 1o. de novembro de 2012, de http://www.ssrn.com/abstract=994684.

Schrickel, W. K. (2000) Análise de crédito: concessão e gerência de empréstimos. (5a. ed.). São Paulo: Atlas. 
Securato, J. R. (Coord.). (2012). Crédito: análise e avaliação do risco: pessoas físicas e jurídicas. (2a. ed.) São Paulo: Saint Paul Editora.

Seifert, D. L. \& Lindberg, D, L. (2010, may). Key provisions on IFRS for small and mediumsized companies. The CPA Journal. 80(5), 34-37.

SEBRAE. (2007). Fatores condicionantes e Taxas de sobrevivência e mortalidade das Micro e Pequenas Empresas do Brasil 2003-2005. Brasília, DF: SEBRAE.

Sian, S. \& Roberts, C. (2009). UK small owner-managed businesses: accounting and financial reporting needs. Journal of Small Business and Enterprise Development. 16(2), 289305. Recuperado em 30 de outubro de 2012, de http://www.emeraldinsight.com/10.1108/14626000910956065.

Silva, J. P. (2008). Gestão e Análise de risco de crédito. (6a. ed.). São Paulo: Atlas.

Souza, D. L. R.; Fonseca, I. J. R., Oliveira, M. C., Marques, V. A. \& Alves, W. R. (2006). O papel da contabilidade na captação de recursos nas instituições brasileiras. Revista Mineira de Contabilidade, 11(39), 6-14.

Souza, R. G. (2009). Normas internacionais de contabilidade: percepções dos profissionais quanto às barreiras para sua adoção no Brasil. Dissertação de Mestrado em Administração de Empresas. Escola de Administração de Empresas de São Paulo (FGV-SP), São Paulo.

Srinivasan, V. \& Kim, Y. H. (1987). Credit Granting: A Comparative Analysis of Classification Procedures. The journal of finance. 42(3), 665 -681

Stevenson, W. J. (1981). Estatística aplicada à administração. (A. A. Farias, trad.). São Paulo: Harper \& Row do Brasil.

Weffort, E. F. J. (2005). O Brasil e a harmonização contábil internacional: influências dos sistemas jurídico e educacional, da cultura e do mercado. São Paulo: Atlas. 
THE WORLD BANK. (2012). Ease of Doing Business Index - Brazil. Recuperado em 3 de novembro de 2012, de http://www.doingbusiness.org/data/exploreeconomies/brazil.

THE WORLD BANK. (2005, 20th july). Report on Observance of Standards and Codes (ROSC) - Accounting and Auditing. Recuperado em 24 de outubro de 2012, de http://www.worldbank.org/ifa/rosc_aa_bra.pdf.

Wright, G. B., Fernandez, D., Burns, J., Hawkins, R., Hornsby, C. \& Patel, S. (2012, may). Big GAAP/littlte GAAP: will the debate never end? Journal of Business \& Economics Research, 10(5), 291-302.

Ueno, R. B. \& Casa Nova, S. P. C. (2006). Um estudo sobre a percepção do micro e pequeno empresário sobre a importância da contabilidade no processo de tomada de decisão. In: IX SEMEAD - Seminários em Administração. São Paulo.

UNIVERSIDADE DE SÃO PAULO (USP). (2009). Diretrizes para apresentação de dissertações e teses da USP: documento eletrônico e impresso Parte II (APA); Vânia Martins Bueno de Oliveira Funaro (Coord.) (2a. ed. Rev. ampl.) São Paulo: Sistema Integrado de Bibliotecas da USP. 85. p.

Valor econômico. (2012, 13 de novembro). PMEs pagam o dobro por crédito da América Latina [Reportagem].

Verrechia, R. E. (2001). Essays on disclosure. Journal of Accounting \& Economics. 32, 97-180. Recuperado em 25 de fevereiro de 2013, de http://roselink.com/references/verrecchia_2001.pdf.

Verrone, M. A. G. (2007). Basiléia II no Brasil: uma reflexão com foco na regulação bancária para risco de crédito - resolução CMN 2.682/99. Dissertação de Mestrado, FEA/USP, Universidade de São Paulo, São Paulo, Brasil.

Yamamoto, M. M. (2005). Teoria da divulgação aplicada ao mercado de capitais brasileiro sob a perspectiva da governança corporativa. Tese de Livre Docência. FEA/USP, Universidade de São Paulo, São Paulo, Brasil. 
Yamamoto, M. M. \& Salotti, B. M. (2006). Informação contábil: estudos sobre a sua divulgação no mercado de capitais. São Paulo: Atlas.

Yanaka, G. M. \& Holland, M. (2010). Basileia II e exigência de capital para risco de crédito dos bancos no Brasil. Revista Brasileira de Finanças. 8(2), 167-195.

Zambaldi, F., Aranha, F., Lopes, H. \& Politi, R. (2011, march). Credit granting to small firms: a Brazilian case. Journal of Business Research. 64(3), 309-315.

Zuelch, H. \& Burghardt, S. (2010). The granting of loans by German banks to SMEs against the background of international financial reporting. Journal of Applied Accounting Research, 10(1), 43-57. Recuperado em 31 de outubro de 2012, de http://www.emeraldinsight.com/0967-5426.htm. 


\section{APÊNDICES}

\section{Apêndice A - Exemplo de Cálculo do Índice de Disclosure}

\begin{tabular}{|c|c|c|c|c|c|c|}
\hline \multirow[t]{2}{*}{393 - Empresas XPTO S.A. } & \multicolumn{2}{|c|}{2009} & \multicolumn{2}{|c|}{2010} & \multicolumn{2}{|c|}{2011} \\
\hline & $\mathrm{M}$ & $\mathrm{T}$ & $\mathrm{M}$ & $\mathrm{T}$ & $\mathrm{M}$ & $\mathrm{T}$ \\
\hline \multicolumn{7}{|l|}{1 - Padrão contábil } \\
\hline 1.1 - Evidenciação do padrão contábil utilizado baseado no CPC & 1 & 1 & 1 & 1 & 1 & 1 \\
\hline 1.2 - Relatório de Administração & 1 & 0 & 1 & 0 & 1 & 0 \\
\hline 1.3 - Evidenciação de Atividade Principal da empresa & 1 & 1 & 1 & 1 & 1 & 1 \\
\hline 1-4 - Evidenciação de Notas explicativas & 1 & 1 & 1 & 1 & 1 & 1 \\
\hline 1.5 - Intenso detalhamento em notas explicativas (+ que $10 \mathrm{NE})$ & 1 & 1 & 1 & 1 & 1 & 1 \\
\hline 1.6 - Evidenciação de DFC e DMPL & 1 & 1 & 1 & 1 & 1 & 1 \\
\hline \multicolumn{7}{|l|}{2 - Ativo Imobilizado } \\
\hline 2.1 - Evidenciação de prática contábil em NE & 1 & 1 & 1 & 1 & 1 & 1 \\
\hline 2.2 - Evidenciação da composição em NE & 1 & 1 & 1 & 1 & 1 & 1 \\
\hline 2.3 - Custo atribuído (evidenciação na primeira adoção) & 0 & 0 & 0 & 0 & 0 & 0 \\
\hline 2.4 - Evidenciação de prática e realização de impairment & 1 & 1 & 1 & 1 & 1 & 1 \\
\hline 2.5 - Evidenciação de vida útil conforme depreciação econômica & 1 & 1 & 1 & 1 & 1 & 1 \\
\hline \multicolumn{7}{|l|}{3 - Ativo Intangível } \\
\hline 3.1 - Utilização da rubrica & 1 & 1 & 1 & 1 & 1 & 1 \\
\hline 3.2 - Evidenciação de prática contábil em NE & 1 & 1 & 1 & 1 & 1 & 1 \\
\hline 3.3 - Evidenciação da composição em NE & 1 & 1 & 1 & 1 & 1 & 1 \\
\hline 3.4 - Evidenciação da amortização de vida útil do ativo em até 10 anos & 0 & 0 & 1 & 1 & 1 & 0 \\
\hline \multicolumn{7}{|l|}{4 - Estoques } \\
\hline 4.1 - Evidenciação de prática contábil em NE & 1 & 1 & 1 & 1 & 1 & 1 \\
\hline 4.2 - Evidenciação de estoques em NE & 1 & 1 & 1 & 1 & 1 & 1 \\
\hline 4.3 - Evidenciação de contabilização a valor justo em NE & 1 & 1 & 1 & 1 & 1 & 1 \\
\hline \multicolumn{7}{|l|}{5 - Empréstimos e Financiamentos } \\
\hline 5.1 - Evidenciação de prática contábil de instrumentos financeiros em NE & 1 & 1 & 1 & 1 & 1 & 1 \\
\hline 5.2 - Evidenciação de endividamento em NE (Custos) & 1 & 1 & 1 & 1 & 1 & 1 \\
\hline 5.3 - Evidenciação de endividamento em NE (Instituição) & 1 & 0 & 1 & 0 & 1 & 0 \\
\hline 5.4 - Evidenciação de endividamento em NE (Tipo) & 1 & 1 & 1 & 1 & 1 & 1 \\
\hline 5.5 - Evidenciação de endividamento em NE (Prazos) & 1 & 1 & 1 & 0 & 1 & 0 \\
\hline \multicolumn{7}{|l|}{6 - Auditoria } \\
\hline 6.1 - Evidenciação de realização de auditoria externa & 1 & 1 & 1 & 1 & 1 & 1 \\
\hline 6.2 - Apresentação de parecer de auditoria & 1 & 1 & 1 & 1 & 1 & 0 \\
\hline Total & 23 & 21 & 24 & 21 & 24 & 19 \\
\hline Índice & & 0,91 & & 0,88 & & 0,79 \\
\hline
\end{tabular}




\section{Apêndice B - Pauta de entrevista}

São Paulo, 6 de fevereiro de 2013.

\section{CARTA DE CONFORTO E SIGILO}

Prezados senhores,

Pela presente carta, informamos que a entrevista solicitada a esta instituição financeira tem o intuito de levantar informações sobre os procedimentos de concessão de crédito a empresas de "Middle-Market" (Indústria e comércio de pequeno e médio porte), para agregar dados que relacionem as informações contábeis com o processo de concessão de crédito bancário a esse tipo de entidade, objeto de dissertação de mestrado em andamento junto ao Programa de Mestrado e Doutorado em Controladoria e Contabilidade da Faculdade de Economia, Administração e Contabilidade da Universidade de São Paulo.

Informamos também que todas as respostas não serão de nenhuma maneira nominalmente identificadas, com o objetivo de preservar a individualidade dos respondentes e o anonimato de vossa instituição. Da mesma forma, não serão associadas, de modo direto ou indireto, quaisquer das suas respostas e informações à instituição entrevistada. $\mathrm{O}$ uso das informações obtidas terá fins exclusivamente acadêmicos. Os resultados do trabalho serão integralmente disponibilizados aos que mostrarem interesse em havê-los.

Segue abaixo a pauta da entrevista a ser realizada com os responsáveis pela área de crédito da instituição.

1) Como é o procedimento padrão para análise e concessão de crédito a uma empresa de "Middle-Market"? Informações contábeis fazem parte do processo de concessão de crédito? Há uso de informações compartilhadas (ex. Serasa)? 
2) Qual é a sua percepção quanto ao padrão contábil CPC-PME (Comitê de Pronunciamentos Contábeis - Pequenas e Médias Empresas)? De alguma forma o padrão contábil adotado pelas empresas pode influenciar sobre montantes, taxas e prazos nos créditos concedidos a empresas de "Middle-Market"?

3) A instituição está preparada para analisar demonstrações financeiras em conformidade com o padrão contábil CPC-PME?

Desde já agradecemos a atenção dispensada e nos colocamos à inteira disposição para dirimir quaisquer dúvidas.

Atenciosamente,

Enrico Dalla Riva

Mestrando do PPGCC da FEA-USP

Prof. Dr. Bruno Meirelles Salotti

Orientador da Pesquisa

Profa. Dra. Silvia Pereira de Castro Casa Nova

Coordenadora do PPGCC da FEA-USP 
Apêndice C - Cálculo das estatísticas descritivas por Região em 2009

\begin{tabular}{|c|c|c|c|c|c|c|c|}
\hline Região/Ano & & \multicolumn{6}{|c|}{2009} \\
\hline Centro & $\mathbf{N}$ & Média & Mediana & Mínimo & Máximo & DP & CV \\
\hline $\mathrm{I}_{1}$ & 22 & 1,01 & 0,13 & 0,00 & 11,99 & 2,70 & 2,67 \\
\hline $\mathrm{I}_{2}$ & 22 & 0,03 & 0,03 & 0,00 & 0,10 & 0,03 & 0,77 \\
\hline $\mathrm{I}_{3}$ & 22 & 0,42 & 0,02 & $(0,15)$ & 7,85 & 1,67 & 3,98 \\
\hline Faturamento & 22 & 126.384 & 116.132 & 36.417 & 235.507 & 55.290 & 0,44 \\
\hline Ativo & 22 & 87.574 & 83.464 & 25.876 & 179.971 & 42.372 & 0,48 \\
\hline ROE & 22 & 0,28 & 0,21 & $(1,80)$ & 1,92 & 0,68 & 2,43 \\
\hline Endividamento & 22 & 0,59 & 0,47 & 0,28 & 1,31 & 0,30 & 0,50 \\
\hline Auditoria & 22 & 0,50 & 0,50 & 0,00 & 1,00 & 0,51 & 1,02 \\
\hline Big Four & 22 & 0,18 & 0,00 & 0,00 & 1,00 & 0,39 & 2,17 \\
\hline $\mathrm{CPC}$ & 22 & 0,50 & 0,50 & 0,00 & 1,00 & 0,51 & 1,02 \\
\hline Disclosure & 22 & 0,57 & 0,69 & 0,00 & 0,98 & 0,33 & 0,58 \\
\hline CPC-PME & 22 & & & & & & \\
\hline $\mathrm{I}_{1}$ & $\mathbf{N}$ & Média & Mediana & Mínimo & Máximo & DP & CV \\
\hline $\mathrm{I}_{2}$ & 26 & 0,48 & 0,07 & 0,00 & 10,34 & 2,01 & 4,21 \\
\hline $\mathrm{I}_{3}$ & 26 & 0,09 & 0,05 & 0,00 & 0,45 & 0,12 & 1,27 \\
\hline $\mathrm{I}_{1}$ & 26 & 0,14 & 0,06 & 0,00 & 0,64 & 0,18 & 1,30 \\
\hline Faturamento & 26 & 137.996 & 136.735 & 44.478 & 234.590 & 59.733 & 0,43 \\
\hline Ativo & 26 & 101.830 & 105.826 & 15.982 & 212.730 & 53.330 & 0,52 \\
\hline ROE & 26 & 0,11 & 0,12 & $(0,93)$ & 0,88 & 0,29 & 2,65 \\
\hline Endividamento & 26 & 0,96 & 0,54 & 0,16 & 11,48 & 2,16 & 2,25 \\
\hline Auditoria & 26 & 0,62 & 1,00 & 0,00 & 1,00 & 0,50 & 0,81 \\
\hline Big Four & 26 & 0,19 & 0,00 & 0,00 & 1,00 & 0,40 & 2,09 \\
\hline $\mathrm{CPC}$ & 26 & 0,35 & 0,00 & 0,00 & 1,00 & 0,49 & 1,40 \\
\hline Disclosure & 26 & 0,58 & 0,66 & 0,00 & 0,95 & 0,29 & 0,51 \\
\hline CPC-PME & 26 & & & & & & \\
\hline Sudeste & $\mathbf{N}$ & Média & Mediana & Mínimo & Máximo & DP & CV \\
\hline $\mathrm{I}_{1}$ & 92 & 0,28 & 0,09 & 0,00 & 5,33 & 0,77 & 2,73 \\
\hline $\mathrm{I}_{2}$ & 92 & 0,05 & 0,04 & 0,00 & 0,21 & 0,04 & 0,90 \\
\hline $\mathrm{I}_{3}$ & 92 & $(0,02)$ & 0,03 & $(8,99)$ & 0,79 & 0,96 & $(57,84)$ \\
\hline Faturamento & 92 & 146.933 & 146.918 & 24.553 & 284.206 & 57.930 & 0,39 \\
\hline Ativo & 92 & 103.984 & 104.620 & 21.012 & 200.609 & 42.567 & 0,41 \\
\hline ROE & 92 & 0,12 & 0,12 & $(5,59)$ & 1,95 & 0,85 & 7,33 \\
\hline Endividamento & 92 & 0,59 & 0,56 & 0,15 & 3,04 & 0,36 & 0,61 \\
\hline Auditoria & 92 & 0,38 & 0,00 & 0,00 & 1,00 & 0,49 & 1,28 \\
\hline Big Four & 92 & 0,16 & 0,00 & 0,00 & 1,00 & 0,37 & 2,28 \\
\hline $\mathrm{CPC}$ & 92 & 0,32 & 0,00 & 0,00 & 1,00 & 0,47 & 1,48 \\
\hline Disclosure & 92 & 0,47 & 0,54 & 0,00 & 0,96 & 0,33 & 0,69 \\
\hline CPC-PME & 92 & & & & & & \\
\hline Sul & $\mathbf{N}$ & Média & Mediana & Mínimo & Máximo & DP & CV \\
\hline $\mathrm{I}_{1}$ & 39 & 0,27 & 0,12 & 0,00 & 4,16 & 0,66 & 2,47 \\
\hline $\mathrm{I}_{2}$ & 39 & 0,05 & 0,05 & 0,00 & 0,15 & 0,03 & 0,64 \\
\hline $\mathrm{I}_{3}$ & 39 & 0,17 & 0,07 & $(0,04)$ & 1,08 & 0,25 & 1,48 \\
\hline Faturamento & 39 & 150.372 & 139.806 & 64.913 & 297.828 & 59.307 & 0,39 \\
\hline Ativo & 39 & 101.197 & 91.314 & 21.815 & 195.042 & 51.119 & 0,51 \\
\hline ROE & 39 & 0,08 & 0,12 & $(1,88)$ & 1,69 & 0,53 & 6,86 \\
\hline Endividamento & 39 & 0,68 & 0,58 & 0,23 & 3,89 & 0,56 & 0,82 \\
\hline Auditoria & 39 & 0,41 & 0,00 & 0,00 & 1,00 & 0,50 & 1,21 \\
\hline Big Four & 39 & 0,05 & 0,00 & 0,00 & 1,00 & 0,22 & 4,36 \\
\hline $\mathrm{CPC}$ & 39 & 0,33 & 0,00 & 0,00 & 1,00 & 0,48 & 1,43 \\
\hline Disclosure & 39 & 0,54 & 0,58 & 0,03 & 1,00 & 0,29 & 0,53 \\
\hline CPC-PME & 39 & & & & & & \\
\hline
\end{tabular}


Apêndice D - Cálculo das estatísticas descritivas por Região em 2010

\begin{tabular}{|c|c|c|c|c|c|c|c|}
\hline Região/Ano & & & & 2010 & & & \\
\hline Centro & $\mathbf{N}$ & Média & Mediana & Mínimo & Máximo & DP & CV \\
\hline $\mathrm{I}_{1}$ & 22 & 0,58 & 0,11 & 0,00 & 4,54 & 1,21 & 2,08 \\
\hline $\mathrm{I}_{2}$ & 22 & 0,04 & 0,03 & 0,00 & 0,12 & 0,03 & 0,84 \\
\hline $\mathrm{I}_{3}$ & 22 & 0,17 & 0,04 & $(0,59)$ & 3,58 & 0,77 & 4,49 \\
\hline Faturamento & 22 & 148.320 & 128.308 & 70.192 & 281.461 & 61.498 & 0,41 \\
\hline Ativo & 22 & 104.012 & 87.979 & 38.060 & 219.755 & 49.231 & 0,47 \\
\hline ROE & 22 & 0,05 & 0,21 & $(3,69)$ & 0,79 & 0,87 & 19,32 \\
\hline Endividamento & 22 & 0,54 & 0,46 & 0,23 & 1,18 & 0,26 & 0,48 \\
\hline Auditoria & 22 & 0,55 & 1,00 & 0,00 & 1,00 & 0,51 & 0,93 \\
\hline Big Four & 22 & 0,18 & 0,00 & 0,00 & 1,00 & 0,39 & 2,17 \\
\hline $\mathrm{CPC}$ & 22 & 0,59 & 1,00 & 0,00 & 1,00 & 0,50 & 0,85 \\
\hline Disclosure & 22 & 0,62 & 0,74 & 0,05 & 0,97 & 0,32 & 0,51 \\
\hline CPC-PME & 22 & 0,27 & 0,00 & 0,00 & 1,00 & 0,46 & 1,67 \\
\hline Nordeste & $\mathbf{N}$ & Média & Mediana & Mínimo & Máximo & DP & $\mathrm{CV}$ \\
\hline $\mathrm{I}_{1}$ & 26 & 0,17 & 0,07 & 0,00 & 2,43 & 0,46 & 2,75 \\
\hline $\mathrm{I}_{2}$ & 26 & 0,04 & 0,04 & 0,00 & 0,12 & 0,03 & 0,71 \\
\hline $\mathrm{I}_{3}$ & 26 & 0,11 & 0,06 & 0,00 & 0,94 & 0,19 & 1,66 \\
\hline Faturamento & 26 & 157.515 & 160.348 & 58.027 & 279.024 & 67.545 & 0,43 \\
\hline Ativo & 26 & 118.653 & 116.430 & 21.284 & 214.011 & 52.624 & 0,44 \\
\hline ROE & 26 & 0,02 & 0,10 & $(1,31)$ & 0,45 & 0,35 & 14,44 \\
\hline Endividamento & 26 & 0,80 & 0,52 & 0,20 & 7,05 & 1,30 & 1,62 \\
\hline Auditoria & 26 & 0,69 & 1,00 & 0,00 & 1,00 & 0,47 & 0,68 \\
\hline Big Four & 26 & 0,19 & 0,00 & 0,00 & 1,00 & 0,40 & 2,09 \\
\hline $\mathrm{CPC}$ & 26 & 0,42 & 0,00 & 0,00 & 1,00 & 0,50 & 1,19 \\
\hline Disclosure & 26 & 0,56 & 0,64 & 0,05 & 1,00 & 0,32 & 0,58 \\
\hline CPC-PME & 26 & 0,12 & 0,00 & 0,00 & 1,00 & 0,33 & 2,82 \\
\hline Sudeste & $\mathbf{N}$ & Média & Mediana & Mínimo & Máximo & DP & $\mathrm{CV}$ \\
\hline $\mathrm{I}_{1}$ & 92 & 1,16 & 0,09 & 0,00 & 64,42 & 7,00 & 6,05 \\
\hline $\mathrm{I}_{2}$ & 92 & 0,04 & 0,03 & 0,00 & 0,26 & 0,04 & 0,98 \\
\hline $\mathrm{I}_{3}$ & 92 & 0,08 & 0,04 & $-0,25$ & 0,91 & 0,15 & 1,91 \\
\hline Faturamento & 92 & 175.587 & 179.480 & 60.945 & 294.478 & 65.769 & 0,37 \\
\hline Ativo & 92 & 120.062 & 118.694 & 24.609 & 226.640 & 46.060 & 0,38 \\
\hline ROE & 92 & 0,20 & 0,16 & $(1,48)$ & 1,77 & 0,38 & 1,91 \\
\hline Endividamento & 92 & 0,55 & 0,56 & 0,07 & 1,20 & 0,20 & 0,36 \\
\hline Auditoria & 92 & 0,43 & 0,00 & 0,00 & 1,00 & 0,50 & 1,15 \\
\hline Big Four & 92 & 0,18 & 0,00 & 0,00 & 1,00 & 0,39 & 2,11 \\
\hline СPC & 92 & 0,57 & 1,00 & 0,00 & 1,00 & 0,50 & 0,88 \\
\hline Disclosure & 92 & 0,59 & 0,64 & 0,00 & 1,00 & 0,31 & 0,53 \\
\hline CPC-PME & 92 & 0,05 & 0,00 & 0,00 & 1,00 & 0,23 & 4,19 \\
\hline Sul & $\mathbf{N}$ & Média & Mediana & Mínimo & Máximo & DP & $\mathrm{CV}$ \\
\hline$I_{1}$ & 39 & 0,47 & 0,11 & 0,00 & 14,03 & 2,23 & 4,70 \\
\hline $\mathrm{I}_{2}$ & 39 & 0,04 & 0,04 & 0,00 & 0,12 & 0,02 & 0,55 \\
\hline$I_{3}$ & 39 & 0,16 & 0,06 & $-0,03$ & 1,62 & 0,28 & 1,80 \\
\hline Faturamento & 39 & 167.252 & 158.479 & 62.997 & 273.562 & 61.013 & 0,36 \\
\hline Ativo & 39 & 116.247 & 125.036 & 26.289 & 206.661 & 52.027 & 0,45 \\
\hline ROE & 39 & 0,14 & 0,15 & $(0,92)$ & 0,92 & 0,26 & 1,82 \\
\hline Endividamento & 39 & 0,64 & 0,60 & 0,27 & 2,47 & 0,37 & 0,57 \\
\hline Auditoria & 39 & 0,44 & 0,00 & 0,00 & 1,00 & 0,50 & 1,15 \\
\hline Big Four & 39 & 0,08 & 0,00 & 0,00 & 1,00 & 0,27 & 3,51 \\
\hline $\mathrm{CPC}$ & 39 & 0,49 & 0,00 & 0,00 & 1,00 & 0,51 & 1,04 \\
\hline Disclosure & 39 & 0,58 & 0,58 & 0,03 & 0,96 & 0,30 & 0,52 \\
\hline CPC-PME & 39 & 0,13 & 0,00 & 0,00 & 1,00 & 0,34 & 2,64 \\
\hline
\end{tabular}


Apêndice E - Cálculo das estatísticas descritivas por Região em 2011

\begin{tabular}{|c|c|c|c|c|c|c|c|}
\hline Região/Ano & & & & 2011 & & & \\
\hline Centro & $\mathbf{N}$ & Média & Mediana & Mínimo & Máximo & DP & CV \\
\hline $\mathrm{I}_{1}$ & 22 & 0,67 & 0,13 & 0,00 & 4,51 & 1,29 & 1,93 \\
\hline $\mathrm{I}_{2}$ & 22 & 0,04 & 0,03 & 0,00 & 0,14 & 0,04 & 0,93 \\
\hline$I_{3}$ & 22 & 0,07 & 0,04 & $(0,02)$ & 0,50 & 0,12 & 1,72 \\
\hline Faturamento & 22 & 161.976 & 147.973 & 86.984 & 299.384 & 64.671 & 0,40 \\
\hline Ativo & 22 & 120.452 & 117.335 & 38.163 & 234.194 & 52.488 & 0,44 \\
\hline ROE & 22 & 0,13 & 0,17 & $(0,73)$ & 0,65 & 0,33 & 2,48 \\
\hline Endividamento & 22 & 0,55 & 0,48 & 0,24 & 1,21 & 0,24 & 0,43 \\
\hline Auditoria & 22 & 0,64 & 1,00 & 0,00 & 1,00 & 0,49 & 0,77 \\
\hline Big Four & 22 & 0,27 & 0,00 & 0,00 & 1,00 & 0,46 & 1,67 \\
\hline CPC & 22 & 0,68 & 1,00 & 0,00 & 1,00 & 0,48 & 0,70 \\
\hline Disclosure & 22 & 0,70 & 0,76 & 0,05 & 1,00 & 0,26 & 0,37 \\
\hline CPC-PME & 22 & 0,18 & 0,00 & 0,00 & 1,00 & 0,39 & 2,17 \\
\hline Nordeste & $\mathbf{N}$ & Média & Mediana & Mínimo & Máximo & DP & $\mathrm{CV}$ \\
\hline $\mathrm{I}_{1}$ & 26 & 0,65 & 0,08 & 0,00 & 14,43 & 2,81 & 4,30 \\
\hline $\mathrm{I}_{2}$ & 26 & 0,06 & 0,06 & 0,00 & 0,23 & 0,05 & 0,84 \\
\hline $\mathrm{I}_{3}$ & 26 & 0,17 & 0,08 & 0,00 & 0,71 & 0,19 & 1,13 \\
\hline Faturamento & 26 & 172.957 & 190.650 & 81.915 & 286.524 & 65.495 & 0,38 \\
\hline Ativo & 26 & 134.951 & 142.770 & 15.826 & 232.596 & 59.047 & 0,44 \\
\hline ROE & 26 & 0,01 & 0,07 & $(1,01)$ & 0,47 & 0,33 & 30,21 \\
\hline Endividamento & 26 & 0,83 & 0,58 & 0,14 & 7,35 & 1,36 & 1,64 \\
\hline Auditoria & 26 & 0,77 & 1,00 & 0,00 & 1,00 & 0,43 & 0,56 \\
\hline Big Four & 26 & 0,31 & 0,00 & 0,00 & 1,00 & 0,47 & 1,53 \\
\hline $\mathrm{CPC}$ & 26 & 0,58 & 1,00 & 0,00 & 1,00 & 0,50 & 0,87 \\
\hline Disclosure & 26 & 0,66 & 0,74 & 0,14 & 1,00 & 0,25 & 0,38 \\
\hline CPC-PME & 26 & 0,12 & 0,00 & 0,00 & 1,00 & 0,33 & 2,82 \\
\hline Sudeste & $\mathbf{N}$ & Média & Mediana & Mínimo & Máximo & DP & CV \\
\hline $\mathrm{I}_{1}$ & 92 & 0,52 & 0,08 & 0,00 & 14,51 & 2,16 & 4,17 \\
\hline $\mathrm{I}_{2}$ & 92 & 0,04 & 0,04 & 0,00 & 0,22 & 0,04 & 0,85 \\
\hline $\mathrm{I}_{3}$ & 92 & 0,01 & 0,04 & $-6,40$ & 1,00 & 0,69 & 48,88 \\
\hline Faturamento & 92 & 191.624 & 198.678 & 51.152 & 296.108 & 67.834 & 0,35 \\
\hline Ativo & 92 & 131.331 & 134.100 & 34.785 & 219.066 & 47.006 & 0,36 \\
\hline ROE & 92 & 0,23 & 0,16 & $(0,59)$ & 4,08 & 0,58 & 2,59 \\
\hline Endividamento & 92 & 0,58 & 0,57 & 0,07 & 2,20 & 0,27 & 0,46 \\
\hline Auditoria & 92 & 0,47 & 0,00 & 0,00 & 1,00 & 0,50 & 1,07 \\
\hline Big Four & 92 & 0,20 & 0,00 & 0,00 & 1,00 & 0,40 & 2,04 \\
\hline $\mathrm{CPC}$ & 92 & 0,60 & 1,00 & 0,00 & 1,00 & 0,49 & 0,82 \\
\hline Disclosure & 92 & 0,61 & 0,68 & 0,02 & 1,00 & 0,31 & 0,51 \\
\hline CPC-PME & 92 & 0,07 & 0,00 & 0,00 & 1,00 & 0,25 & 3,81 \\
\hline Sul & $\mathbf{N}$ & Média & Mediana & Mínimo & Máximo & DP & CV \\
\hline $\mathrm{I}_{1}$ & 39 & 0,17 & 0,11 & 0,00 & 2,21 & 0,35 & 2,02 \\
\hline $\mathrm{I}_{2}$ & 39 & 0,05 & 0,05 & 0,00 & 0,14 & 0,03 & 0,67 \\
\hline $\mathrm{I}_{3}$ & 39 & 0,21 & 0,06 & $-0,05$ & 1,57 & 0,39 & 1,81 \\
\hline Faturamento & 39 & 194.462 & 217.376 & 80.843 & 299.370 & 67.589 & 0,35 \\
\hline Ativo & 39 & 129.845 & 134.050 & 36.790 & 224.829 & 55.216 & 0,43 \\
\hline ROE & 39 & 0,14 & 0,15 & $(1,33)$ & 1,12 & 0,34 & 2,48 \\
\hline Endividamento & 39 & 0,66 & 0,62 & 0,26 & 2,36 & 0,35 & 0,53 \\
\hline Auditoria & 39 & 0,51 & 1,00 & 0,00 & 1,00 & 0,51 & 0,99 \\
\hline Big Four & 39 & 0,10 & 0,00 & 0,00 & 1,00 & 0,31 & 3,00 \\
\hline $\mathrm{CPC}$ & 39 & 0,59 & 1,00 & 0,00 & 1,00 & 0,50 & 0,84 \\
\hline Disclosure & 39 & 0,63 & 0,64 & 0,00 & 1,00 & 0,28 & 0,44 \\
\hline CPC-PME & 39 & 0,18 & 0,00 & 0,00 & 1,00 & 0,39 & 2,17 \\
\hline
\end{tabular}


Apêndice F - Cálculo das estatísticas descritivas por Setor em 2009

\begin{tabular}{|c|c|c|c|c|c|c|c|}
\hline \multirow{2}{*}{$\begin{array}{l}\text { Setor/Ano } \\
\text { Agronegócios }\end{array}$} & \multirow[b]{2}{*}{$\mathbf{N}$} & \multicolumn{6}{|c|}{2009} \\
\hline & & Média & Mediana & Mínimo & Máximo & DP & $\mathrm{CV}$ \\
\hline $\mathrm{I}_{1}$ & 31 & 0,34 & 0,10 & 0,00 & 4,75 & 0,85 & 2,49 \\
\hline $\mathrm{I}_{2}$ & 31 & 0,06 & 0,05 & 0,00 & 0,16 & 0,04 & 0,64 \\
\hline $\mathrm{I}_{3}$ & 31 & 0,19 & 0,09 & $(0,01)$ & 1,08 & 0,27 & 1,43 \\
\hline Faturamento & 31 & 108.549 & 100.138 & 36.417 & 297.828 & 52.972 & 0,49 \\
\hline Ativo & 31 & 98.148 & 101.528 & 26.852 & 179.971 & 40.364 & 0,41 \\
\hline ROE & 31 & 0,20 & 0,12 & $(1,88)$ & 1,92 & 0,74 & 3,77 \\
\hline Endividamento & 31 & 0,62 & 0,62 & 0,20 & 1,32 & 0,25 & 0,40 \\
\hline Auditoria & 31 & 0,35 & 0,00 & 0,00 & 1,00 & 0,49 & 1,37 \\
\hline Big Four & 31 & 0,10 & 0,00 & 0,00 & 1,00 & 0,30 & 3,11 \\
\hline CPC & 31 & 0,35 & 0,00 & 0,00 & 1,00 & 0,49 & 1,37 \\
\hline Disclosure & 31 & 0,50 & 0,54 & 0,00 & 0,91 & 0,29 & 0,58 \\
\hline \multicolumn{8}{|l|}{ CPC-PME } \\
\hline Base & $\mathbf{N}$ & Média & Mediana & Mínimo & Máximo & DP & CV \\
\hline$I_{1}$ & 46 & 0,35 & 0,09 & 0,00 & 10,34 & 1,51 & 4,31 \\
\hline $\mathrm{I}_{2}$ & 46 & 0,07 & 0,04 & 0,00 & 0,45 & 0,10 & 1,46 \\
\hline $\mathrm{I}_{3}$ & 46 & 0,10 & 0,03 & $-8,99$ & 0,64 & 1,35 & $-13,85$ \\
\hline Faturamento & 46 & 138.153 & 135.333 & 24.553 & 247.294 & 65.812 & 0,48 \\
\hline Ativo & 46 & 103.590 & 100.244 & 21.815 & 200.609 & 50.370 & 0,49 \\
\hline ROE & 46 & $-\quad 0,05$ & 0,10 & $(5,59)$ & 1,61 & 1,10 & $-24,34$ \\
\hline Endividamento & 46 & 0,54 & 0,49 & 0,15 & 1,76 & 0,28 & 0,52 \\
\hline Auditoria & 46 & 0,41 & 0,00 & 0,00 & 1,00 & 0,50 & 1,21 \\
\hline Big Four & 46 & 0,20 & 0,00 & 0,00 & 1,00 & 0,40 & 2,05 \\
\hline CPC & 46 & 0,33 & 0,00 & 0,00 & 1,00 & 0,47 & 1,45 \\
\hline Disclosure & 46 & 0,47 & 0,54 & 0,00 & 0,93 & 0,34 & 0,72 \\
\hline \multicolumn{8}{|l|}{ CPC-PME } \\
\hline Comércio & $\mathbf{N}$ & Média & Mediana & Mínimo & Máximo & DP & CV \\
\hline$I_{1}$ & 28 & 0,48 & 0,14 & 0,00 & 5,02 & 1,18 & 2,47 \\
\hline $\mathrm{I}_{2}$ & 28 & 0,05 & 0,04 & 0,00 & 0,15 & 0,04 & 0,84 \\
\hline$I_{3}$ & 28 & 0,08 & 0,03 & $(0,15)$ & 0,58 & 0,14 & 1,73 \\
\hline Faturamento & 28 & 165.915 & 173.734 & 64.913 & 284.206 & 57.885 & 0,35 \\
\hline Ativo & 28 & 70.258 & 60.311 & 15.982 & 170.812 & 32.467 & 0,46 \\
\hline ROE & 28 & 0,15 & 0,15 & $(0,94)$ & 1,30 & 0,32 & 2,13 \\
\hline Endividamento & 28 & 0,55 & 0,49 & 0,18 & 1,31 & 0,28 & 0,50 \\
\hline Auditoria & 28 & 0,18 & 0,00 & 0,00 & 1,00 & 0,39 & 2,18 \\
\hline Big Four & 28 & 0,04 & 0,00 & 0,00 & 1,00 & 0,19 & 5,29 \\
\hline CPC & 28 & 0,21 & 0,00 & 0,00 & 1,00 & 0,42 & 1,95 \\
\hline Disclosure & 28 & 0,37 & 0,32 & 0,00 & 0,92 & 0,28 & 0,76 \\
\hline \multicolumn{8}{|l|}{ CPC-PME } \\
\hline Consumo & $\mathbf{N}$ & Média & Mediana & Mínimo & Máximo & DP & $\mathbf{C V}$ \\
\hline $\mathrm{I}_{1}$ & 45 & 0,23 & 0,09 & 0,00 & 3,00 & 0,50 & 2,18 \\
\hline $\mathrm{I}_{2}$ & 45 & 0,05 & 0,04 & 0,00 & 0,11 & 0,03 & 0,63 \\
\hline$I_{3}$ & 45 & 0,29 & 0,05 & 0,00 & 7,85 & 1,16 & 4,00 \\
\hline Faturamento & 45 & 150.438 & 146.896 & 44.478 & 252.888 & 49.665 & 0,33 \\
\hline Ativo & 45 & 116.806 & 116.612 & 21.012 & 212.730 & 45.250 & 0,39 \\
\hline ROE & 45 & 0,12 & 0,11 & $(1,80)$ & 0,88 & 0,36 & 2,94 \\
\hline Endividamento & 45 & 0,57 & 0,55 & 0,19 & 1,01 & 0,18 & 0,32 \\
\hline Auditoria & 45 & 0,53 & 1,00 & 0,00 & 1,00 & 0,50 & 0,95 \\
\hline Big Four & 45 & 0,16 & 0,00 & 0,00 & 1,00 & 0,37 & 2,36 \\
\hline CPC & 45 & 0,44 & 0,00 & 0,00 & 1,00 & 0,50 & 1,13 \\
\hline Disclosure & 45 & 0,55 & 0,57 & 0,00 & 1,00 & 0,29 & 0,53 \\
\hline \multicolumn{8}{|l|}{ CPC-PME } \\
\hline Serviços & $\mathbf{N}$ & Média & Mediana & Mínimo & Máximo & DP & $\mathbf{C V}$ \\
\hline $\mathrm{I}_{1}$ & 29 & 0,72 & 0,09 & 0,00 & 11,99 & 2,38 & 3,31 \\
\hline $\mathrm{I}_{2}$ & 29 & 0,03 & 0,03 & 0,00 & 0,11 & 0,03 & 0,80 \\
\hline $\mathrm{I}_{3}$ & 29 & 0,04 & 0,03 & $(0,14)$ & 0,23 & 0,07 & 1,73 \\
\hline Faturamento & 29 & 159.149 & 170.808 & 81.624 & 245.612 & 47.053 & 0,30 \\
\hline Ativo & 29 & 105.384 & 111.039 & 18.931 & 190.603 & 45.266 & 0,43 \\
\hline ROE & 29 & 0,31 & 0,26 & $(0,93)$ & 1,95 & 0,49 & 1,57 \\
\hline Endividamento & 29 & 1,16 & 0,59 & 0,24 & 11,48 & 2,13 & 1,84 \\
\hline Auditoria & 29 & 0,66 & 1,00 & 0,00 & 1,00 & 0,48 & 0,74 \\
\hline Big Four & 29 & 0,21 & 0,00 & 0,00 & 1,00 & 0,41 & 1,99 \\
\hline CPC & 29 & 0,34 & 0,00 & 0,00 & 1,00 & 0,48 & 1,40 \\
\hline Disclosure & 29 & 0,69 & 0,81 & 0,00 & 0,98 & 0,30 & 0,44 \\
\hline CPC-PME & & & & & & & \\
\hline
\end{tabular}


Apêndice G - Cálculo das estatísticas descritivas por Setor em 2010

\begin{tabular}{|c|c|c|c|c|c|c|c|}
\hline Setor/Ano & & \multicolumn{6}{|c|}{2010} \\
\hline Agronegócios & $\mathbf{N}$ & Média & Mediana & Mínimo & Máximo & DP & $\mathrm{CV}$ \\
\hline $\mathrm{I}_{1}$ & 31 & 0,38 & 0,10 & 0,02 & 4,54 & 0,89 & 2,31 \\
\hline $\mathrm{I}_{2}$ & 31 & 0,04 & 0,04 & 0,00 & 0,16 & 0,03 & 0,76 \\
\hline $\mathrm{I}_{3}$ & 31 & 0,17 & 0,08 & $(0,02)$ & 1,62 & 0,32 & 1,86 \\
\hline Faturamento & 31 & 116.445 & 106.759 & 60.945 & 240.701 & 44.747 & 0,38 \\
\hline Ativo & 31 & 109.412 & 113.349 & 31.330 & 219.755 & 46.409 & 0,42 \\
\hline ROE & 31 & 0,01 & 0,09 & $(1,18)$ & 0,79 & 0,35 & 28,14 \\
\hline Endividamento & 31 & 0,62 & 0,61 & 0,21 & 1,20 & 0,23 & 0,38 \\
\hline Auditoria & 31 & 0,42 & 0,00 & 0,00 & 1,00 & 0,50 & 1,20 \\
\hline Big Four & 31 & 0,06 & 0,00 & 0,00 & 1,00 & 0,25 & 3,87 \\
\hline $\mathrm{CPC}$ & 31 & 0,48 & 0,00 & 0,00 & 1,00 & 0,51 & 1,05 \\
\hline Disclosure & 31 & 0,53 & 0,60 & 0,03 & 0,91 & 0,30 & 0,56 \\
\hline CPC-PME & 31 & 0,16 & 0,00 & 0,00 & 1,00 & 0,37 & 2,32 \\
\hline Ind. de Base & $\mathbf{N}$ & Média & Mediana & Mínimo & Máximo & DP & $\mathrm{CV}$ \\
\hline $\mathrm{I}_{1}$ & 46 & 0,12 & 0,10 & 0,00 & 0,48 & 0,11 & 0,93 \\
\hline $\mathrm{I}_{2}$ & 46 & 0,04 & 0,03 & 0,00 & 0,26 & 0,05 & 1,09 \\
\hline $\mathrm{I}_{3}$ & 46 & 0,08 & 0,04 & $(0,25)$ & 0,91 & 0,18 & 2,09 \\
\hline Faturamento & 46 & 175.183 & 162.787 & 58.027 & 294.478 & 76.153 & 0,43 \\
\hline Ativo & 46 & 124.510 & 119.449 & 26.289 & 226.640 & 51.643 & 0,41 \\
\hline ROE & 46 & 0,29 & 0,18 & $(0,26)$ & 1,77 & 0,37 & 1,30 \\
\hline Endividamento & 46 & 0,51 & 0,50 & 0,07 & 0,96 & 0,21 & 0,42 \\
\hline Auditoria & 46 & 0,48 & 0,00 & 0,00 & 1,00 & 0,51 & 1,06 \\
\hline Big Four & 46 & 0,24 & 0,00 & 0,00 & 1,00 & 0,43 & 1,80 \\
\hline $\mathrm{CPC}$ & 46 & 0,63 & 1,00 & 0,00 & 1,00 & 0,49 & 0,77 \\
\hline Disclosure & 46 & 0,59 & 0,67 & 0,05 & 1,00 & 0,33 & 0,56 \\
\hline CPC-PME & 46 & 0,04 & 0,00 & 0,00 & 1,00 & 0,21 & 4,74 \\
\hline Comércio & $\mathbf{N}$ & Média & Mediana & Mínimo & Máximo & DP & $\mathrm{CV}$ \\
\hline $\mathrm{I}_{1}$ & 28 & 3,66 & 0,11 & 0,00 & 64,42 & 12,69 & 3,47 \\
\hline $\mathrm{I}_{2}$ & 28 & 0,04 & 0,04 & 0,00 & 0,11 & 0,03 & 0,75 \\
\hline $\mathrm{I}_{3}$ & 28 & 0,07 & 0,04 & $(0,59)$ & 0,94 & 0,22 & 3,29 \\
\hline Faturamento & 28 & 185.135 & 194.945 & 62.997 & 281.461 & 62.227 & 0,34 \\
\hline Ativo & 28 & 81.918 & 74.264 & 21.284 & 162.767 & 33.753 & 0,41 \\
\hline ROE & 28 & 0,13 & 0,17 & $(1,48)$ & 0,56 & 0,34 & 2,71 \\
\hline Endividamento & 28 & 0,52 & 0,47 & 0,23 & 0,90 & 0,20 & 0,37 \\
\hline Auditoria & 28 & 0,21 & 0,00 & 0,00 & 1,00 & 0,42 & 1,95 \\
\hline Big Four & 28 & 0,04 & 0,00 & 0,00 & 1,00 & 0,19 & 5,29 \\
\hline $\mathrm{CPC}$ & 28 & 0,18 & 0,00 & 0,00 & 1,00 & 0,39 & 2,18 \\
\hline Disclosure & 28 & 0,39 & 0,33 & 0,04 & 0,91 & 0,25 & 0,65 \\
\hline CPC-PME & 28 & 0,11 & 0,00 & 0,00 & 1,00 & 0,31 & 2,94 \\
\hline Consumo & $\mathbf{N}$ & Média & Mediana & Mínimo & Máximo & DP & $\mathrm{CV}$ \\
\hline $\mathrm{I}_{1}$ & 45 & 0,15 & 0,09 & 0,00 & 1,90 & 0,29 & 1,88 \\
\hline $\mathrm{I}_{2}$ & 45 & 0,04 & 0,04 & 0,00 & 0,12 & 0,02 & 0,57 \\
\hline $\mathrm{I}_{3}$ & 45 & 0,18 & 0,06 & 0,00 & 3,58 & 0,53 & 3,00 \\
\hline Faturamento & 45 & 173.723 & 182.984 & 59.463 & 270.997 & 56.887 & 0,33 \\
\hline Ativo & 45 & 132.600 & 135.211 & 24.609 & 214.011 & 45.976 & 0,35 \\
\hline ROE & 45 & 0,02 & 0,15 & $(3,69)$ & 0,64 & 0,64 & 33,05 \\
\hline Endividamento & 45 & 0,58 & 0,57 & 0,23 & 0,96 & 0,20 & 0,34 \\
\hline Auditoria & 45 & 0,56 & 1,00 & 0,00 & 1,00 & 0,50 & 0,90 \\
\hline Big Four & 45 & 0,13 & 0,00 & 0,00 & 1,00 & 0,34 & 2,58 \\
\hline $\mathrm{CPC}$ & 45 & 0,58 & 1,00 & 0,00 & 1,00 & 0,50 & 0,86 \\
\hline Disclosure & 45 & 0,61 & 0,68 & 0,00 & 1,00 & 0,29 & 0,48 \\
\hline CPC-PME & 45 & 0,09 & 0,00 & 0,00 & 1,00 & 0,29 & 3,24 \\
\hline Serviços & $\mathbf{N}$ & Média & Mediana & Mínimo & Máximo & DP & $\mathrm{CV}$ \\
\hline $\mathrm{I}_{1}$ & 29 & 0,52 & 0,08 & 0,00 & 7,01 & 1,45 & 2,79 \\
\hline $\mathrm{I}_{2}$ & 29 & 0,03 & 0,03 & 0,00 & 0,12 & 0,03 & 0,89 \\
\hline $\mathrm{I}_{3}$ & 29 & 0,04 & 0,02 & $(0,13)$ & 0,29 & 0,08 & 1,89 \\
\hline Faturamento & 29 & 185.027 & 191.957 & 91.425 & 262.963 & 51.555 & 0,28 \\
\hline Ativo & 29 & 123.196 & 125.734 & 36.256 & 202.530 & 46.834 & 0,38 \\
\hline ROE & 29 & 0,26 & 0,31 & $(0,28)$ & 0,92 & 0,26 & 0,99 \\
\hline Endividamento & 29 & 0,86 & 0,63 & 0,20 & 7,05 & 1,26 & 1,47 \\
\hline Auditoria & 29 & 0,72 & 1,00 & 0,00 & 1,00 & 0,45 & 0,63 \\
\hline Big Four & 29 & 0,31 & 0,00 & 0,00 & 1,00 & 0,47 & 1,52 \\
\hline $\mathrm{CPC}$ & 29 & 0,69 & 1,00 & 0,00 & 1,00 & 0,47 & 0,68 \\
\hline Disclosure & 29 & 0,77 & 0,89 & 0,00 & 1,00 & 0,25 & 0,32 \\
\hline CPC-PME & 29 & 0,17 & 0,00 & 0,00 & 1,00 & 0,38 & 2,23 \\
\hline
\end{tabular}


Apêndice H - Cálculo das estatísticas descritivas por Setor em 2011

\begin{tabular}{|c|c|c|c|c|c|c|c|}
\hline Setor/Ano & & \multicolumn{6}{|c|}{2011} \\
\hline Agronegócios & $\mathbf{N}$ & Média & Mediana & Mínimo & Máximo & DP & $\mathrm{CV}$ \\
\hline$I_{1}$ & 31 & 0,31 & 0,07 & 0,00 & 5,50 & 1,01 & 3,25 \\
\hline $\mathrm{I}_{2}$ & 31 & 0,05 & 0,04 & 0,00 & 0,13 & 0,03 & 0,70 \\
\hline $\mathrm{I}_{3}$ & 31 & $(0,02)$ & 0,05 & $(6,40)$ & 1,57 & 1,25 & $(73,47)$ \\
\hline Faturamento & 31 & 133.911 & 118.139 & 51.152 & 263.509 & 53.259 & 0,40 \\
\hline Ativo & 31 & 126.423 & 121.930 & 36.790 & 234.194 & 55.499 & 0,44 \\
\hline ROE & 31 & 0,16 & 0,11 & $(1,33)$ & 3,17 & 0,66 & 4,10 \\
\hline Endividamento & 31 & 0,62 & 0,61 & 0,15 & 1,16 & 0,25 & 0,40 \\
\hline Auditoria & 31 & 0,48 & 0,00 & 0,00 & 1,00 & 0,51 & 1,05 \\
\hline Big Four & 31 & 0,10 & 0,00 & 0,00 & 1,00 & 0,30 & 3,11 \\
\hline $\mathrm{CPC}$ & 31 & 0,55 & 1,00 & 0,00 & 1,00 & 0,51 & 0,92 \\
\hline Disclosure & 31 & 0,58 & 0,65 & 0,04 & 0,96 & 0,30 & 0,52 \\
\hline CPC-PME & 31 & 0,16 & 0,00 & 0,00 & 1,00 & 0,37 & 2,32 \\
\hline Base & $\mathbf{N}$ & Média & Mediana & Mínimo & Máximo & DP & $\mathrm{CV}$ \\
\hline $\mathrm{I}_{1}$ & 46 & 0,42 & 0,08 & 0,00 & 14,43 & 2,11 & 5,08 \\
\hline $\mathrm{I}_{2}$ & 46 & 0,05 & 0,03 & 0,00 & 0,22 & 0,05 & 0,99 \\
\hline $\mathrm{I}_{3}$ & 46 & 0,12 & 0,05 & 0,00 & 1,15 & 0,22 & 1,89 \\
\hline Faturamento & 46 & 187.652 & 186.366 & 75.282 & 296.108 & 70.402 & 0,38 \\
\hline Ativo & 46 & 138.995 & 139.133 & 38.163 & 223.498 & 49.655 & 0,36 \\
\hline ROE & 46 & 0,14 & 0,14 & $(0,59)$ & 0,91 & 0,31 & 2,33 \\
\hline Endividamento & 46 & 0,55 & 0,56 & 0,07 & 0,95 & 0,21 & 0,39 \\
\hline Auditoria & 46 & 0,65 & 1,00 & 0,00 & 1,00 & 0,48 & 0,74 \\
\hline Big Four & 46 & 0,37 & 0,00 & 0,00 & 1,00 & 0,49 & 1,32 \\
\hline $\mathrm{CPC}$ & 46 & 0,74 & 1,00 & 0,00 & 1,00 & 0,44 & 0,60 \\
\hline Disclosure & 46 & 0,70 & 0,81 & 0,05 & 1,00 & 0,27 & 0,39 \\
\hline CPC-PME & 46 & 0,07 & 0,00 & 0,00 & 1,00 & 0,25 & 3,83 \\
\hline Comércio & $\mathbf{N}$ & Média & Mediana & Mínimo & Máximo & DP & $\mathrm{CV}$ \\
\hline$I_{1}$ & 28 & 1,22 & 0,11 & 0,00 & 14,51 & 3,73 & 3,04 \\
\hline $\mathrm{I}_{2}$ & 28 & 0,05 & 0,03 & 0,00 & 0,14 & 0,04 & 0,85 \\
\hline $\mathrm{I}_{3}$ & 28 & 0,08 & 0,04 & 0,00 & 0,42 & 0,11 & 1,29 \\
\hline Faturamento & 28 & 206.015 & 212.813 & 85.309 & 299.384 & 69.365 & 0,34 \\
\hline Ativo & 28 & 95.616 & 88.510 & 15.826 & 183.030 & 40.880 & 0,43 \\
\hline ROE & 28 & 0,16 & 0,17 & $(0,22)$ & 0,75 & 0,18 & 1,14 \\
\hline Endividamento & 28 & 0,54 & 0,51 & 0,26 & 0,93 & 0,19 & 0,35 \\
\hline Auditoria & 28 & 0,29 & 0,00 & 0,00 & 1,00 & 0,46 & 1,61 \\
\hline Big Four & 28 & 0,07 & 0,00 & 0,00 & 1,00 & 0,26 & 3,67 \\
\hline $\mathrm{CPC}$ & 28 & 0,39 & 0,00 & 0,00 & 1,00 & 0,50 & 1,27 \\
\hline Disclosure & 28 & 0,53 & 0,58 & 0,04 & 0,92 & 0,25 & 0,47 \\
\hline CPC-PME & 28 & 0,18 & 0,00 & 0,00 & 1,00 & 0,39 & 2,18 \\
\hline Consumo & $\mathbf{N}$ & Média & Mediana & Mínimo & Máximo & DP & $\mathrm{CV}$ \\
\hline $\mathrm{I}_{1}$ & 45 & 0,18 & 0,10 & 0,00 & 1,16 & 0,25 & 1,33 \\
\hline $\mathrm{I}_{2}$ & 45 & 0,06 & 0,05 & 0,00 & 0,23 & 0,04 & 0,73 \\
\hline $\mathrm{I}_{3}$ & 45 & 0,15 & 0,06 & 0,00 & 0,71 & 0,17 & 1,13 \\
\hline Faturamento & 45 & 198.141 & 218.054 & 89.819 & 293.520 & 61.451 & 0,31 \\
\hline Ativo & 45 & 144.291 & 154.558 & 34.785 & 232.596 & 48.029 & 0,33 \\
\hline ROE & 45 & 0,08 & 0,12 & $(1,01)$ & 0,97 & 0,34 & 4,44 \\
\hline Endividamento & 45 & 0,60 & 0,58 & 0,26 & 1,01 & 0,20 & 0,33 \\
\hline Auditoria & 45 & 0,53 & 1,00 & 0,00 & 1,00 & 0,50 & 0,95 \\
\hline Big Four & 45 & 0,11 & 0,00 & 0,00 & 1,00 & 0,32 & 2,86 \\
\hline $\mathrm{CPC}$ & 45 & 0,58 & 1,00 & 0,00 & 1,00 & 0,50 & 0,86 \\
\hline Disclosure & 45 & 0,58 & 0,60 & 0,00 & 1,00 & 0,30 & 0,52 \\
\hline CPC-PME & 45 & 0,07 & 0,00 & 0,00 & 1,00 & 0,25 & 3,78 \\
\hline Serviços & $\mathbf{N}$ & Média & Mediana & Mínimo & Máximo & DP & $\mathrm{CV}$ \\
\hline $\mathrm{I}_{1}$ & 29 & 0,51 & 0,10 & 0,00 & 4,51 & 1,15 & 2,26 \\
\hline $\mathrm{I}_{2}$ & 29 & 0,04 & 0,03 & 0,00 & 0,09 & 0,03 & 0,75 \\
\hline $\mathrm{I}_{3}$ & 29 & 0,05 & 0,03 & $(0,20)$ & 0,32 & 0,09 & 1,97 \\
\hline Faturamento & 29 & 200.199 & 209.338 & 87.774 & 288.177 & 59.185 & 0,30 \\
\hline Ativo & 29 & 131.791 & 130.525 & 38.305 & 219.066 & 49.377 & 0,37 \\
\hline ROE & 29 & 0,36 & 0,22 & $(0,49)$ & 4,08 & 0,77 & 2,17 \\
\hline Endividamento & 29 & 0,91 & 0,61 & 0,14 & 7,35 & 1,34 & 1,47 \\
\hline Auditoria & 29 & 0,69 & 1,00 & 0,00 & 1,00 & 0,47 & 0,68 \\
\hline Big Four & 29 & 0,31 & 0,00 & 0,00 & 1,00 & 0,47 & 1,52 \\
\hline $\mathrm{CPC}$ & 29 & 0,69 & 1,00 & 0,00 & 1,00 & 0,47 & 0,68 \\
\hline Disclosure & 29 & 0,76 & 0,89 & 0,02 & 1,00 & 0,26 & 0,34 \\
\hline CPC-PME & 29 & 0,14 & 0,00 & 0,00 & 1,00 & 0,35 & 2,54 \\
\hline
\end{tabular}


Apêndice I - Matriz de correlação das variáveis (dados em painel)

\begin{tabular}{|c|c|c|c|c|c|c|c|c|c|c|c|c|c|c|c|c|c|c|c|c|c|c|c|}
\hline Variáveis & $I_{1}$ & $\mathbf{I}_{2}$ & $\mathbf{I}_{3}$ & $I_{1(-1)}$ & $\mathbf{I}_{2(-1)}$ & $\mathbf{I}_{3(-1)}$ & size & roe & debt & Daudit & Dbig4 & Dcpc & Discl & Dsul & Dse & Dco & Dnne & Dcom & Dserv & Dagro & Dcons & Dbase & Dt \\
\hline$I_{1}$ & 1,00 & & & & & & & & & & & & & & & & & & & & & & \\
\hline$I_{2}$ & $-0,04$ & 1,00 & & & & & & & & & & & & & & & & & & & & & \\
\hline$I_{3}$ & $-0,08$ & 0,35 & 1,00 & & & & & & & & & & & & & & & & & & & & \\
\hline $\mathbf{I}_{1(-1)}$ & 0,53 & 0,05 & - 0,06 & 1,00 & & & & & & & & & & & & & & & & & & & \\
\hline$I_{2(-1)}$ & 0,01 & 0,63 & 0,26 & 0,31 & 1,00 & & & & & & & & & & & & & & & & & & \\
\hline$I_{3(-1)}$ & $-0,08$ & 0,32 & 0,79 & 0,04 & 0,42 & 1,00 & & & & & & & & & & & & & & & & & \\
\hline size & $-0,02$ & $-0,09$ & $-0,09$ & 0,03 & $-0,05$ & $-0,05$ & 1,00 & & & & & & & & & & & & & & & & \\
\hline roe & 0,08 & $-0,05$ & $-0,33$ & 0,05 & - 0,06 & $-0,07$ & $-0,02$ & 1,00 & & & & & & & & & & & & & & & \\
\hline debt & $-0,16$ & 0,16 & 0,60 & - 0,09 & 0,09 & 0,62 & 0,07 & $-0,12$ & 1,00 & & & & & & & & & & & & & & \\
\hline Daudit & 0,13 & 0,02 & 0,03 & 0,07 & - 0,06 & $-0,06$ & $-0,02$ & $-0,04$ & - 0,09 & 1,00 & & & & & & & & & & & & & \\
\hline Dbig4 & 0,07 & $-0,16$ & 0,02 & 0,06 & $-0,12$ & 0,05 & 0,17 & $-0,00$ & 0,02 & 0,44 & 1,00 & & & & & & & & & & & & \\
\hline Dcpc & 0,07 & $-0,13$ & $-0,06$ & 0,05 & $-0,15$ & $-0,07$ & 0,05 & 0,05 & $-0,04$ & 0,42 & 0,21 & 1,00 & & & & & & & & & & & \\
\hline Discl & 0,06 & $-0,21$ & $-0,06$ & $-0,03$ & $-0,26$ & $-0,09$ & 0,14 & 0,09 & 0,00 & 0,59 & 0,35 & 0,64 & 1,00 & & & & & & & & & & \\
\hline Dsul & $-0,12$ & 0,01 & 0,22 & $-0,11$ & $-0,00$ & 0,18 & 0,09 & $-0,11$ & 0,07 & $-0,12$ & $-0,18$ & $-0,08$ & $-0,05$ & 1,00 & & & & & & & & & \\
\hline Dse & $-0,04$ & $-0,00$ & $-0,11$ & $-0,05$ & 0,02 & $-0,08$ & 0,05 & 0,03 & 0,07 & $-0,04$ & 0,08 & $-0,01$ & $-0,02$ & $-0,56$ & 1,00 & & & & & & & & \\
\hline Dco & 0,29 & $-0,12$ & $-0,16$ & 0,19 & $-0,14$ & $-0,12$ & $-0,18$ & 0,22 & $-0,21$ & 0,02 & 0,09 & 0,10 & 0,03 & $-0,26$ & $-0,35$ & 1,00 & & & & & & & \\
\hline Dnne & $-0,08$ & 0,11 & 0,04 & 0,02 & 0,12 & $-0,01$ & $-0,00$ & $-0,13$ & 0,01 & 0,20 & 0,02 & 0,02 & 0,07 & $-0,26$ & $-0,35$ & $-0,16$ & 1,00 & & & & & & \\
\hline Dcom & $-0,05$ & $-0,13$ & $-0,13$ & - 0,06 & $-0,06$ & $-0,10$ & 0,15 & 0,01 & $-0,16$ & $-0,20$ & $-0,08$ & $-0,17$ & $-0,18$ & 0,20 & $-0,15$ & 0,02 & $-0,06$ & 1,00 & & & & & \\
\hline Dserv & 0,32 & - 0,09 & $-0,11$ & 0,21 & $-0,12$ & $-0,13$ & 0,15 & 0,11 & $-0,07$ & 0,19 & 0,13 & 0,14 & 0,27 & $-0,22$ & 0,01 & 0,31 & $-0,03$ & $-0,15$ & 1,00 & & & & \\
\hline Dagro & $-0,04$ & $-0,00$ & 0,18 & - 0,01 & 0,06 & 0,21 & $-0,33$ & $-0,05$ & 0,10 & $-0,07$ & $-0,08$ & $-0,02$ & $-0,08$ & $-0,17$ & 0,09 & 0,05 & 0,05 & $-0,18$ & $-0,22$ & 1,00 & & & \\
\hline Dcons & $-0,08$ & 0,13 & 0,03 & - 0,10 & 0,03 & 0,04 & 0,06 & $-0,02$ & 0,09 & 0,05 & $-0,01$ & $-0,00$ & 0,03 & 0,09 & 0,01 & $-0,26$ & 0,12 & $-0,23$ & $-0,28$ & $-0,32$ & 1,00 & & \\
\hline Dbase & $-0,12$ & 0,04 & $-0,01$ & $-0,02$ & 0,06 & $-0,05$ & 0,00 & $-0,03$ & $-0,01$ & $-0,00$ & 0,03 & 0,03 & $-0,06$ & 0,10 & 0,01 & $-0,04$ & $-0,10$ & $-0,20$ & $-0,24$ & $-0,28$ & $-0,36$ & 1,00 & \\
\hline Dt & $-0,02$ & 0,12 & 0,09 & $-0,06$ & $-0,10$ & $-0,05$ & 0,17 & $-0,01$ & 0,01 & 0,03 & $-0,02$ & 0,18 & 0,06 & - & - & - & - & - & - & - & - & - & 1,00 \\
\hline
\end{tabular}

